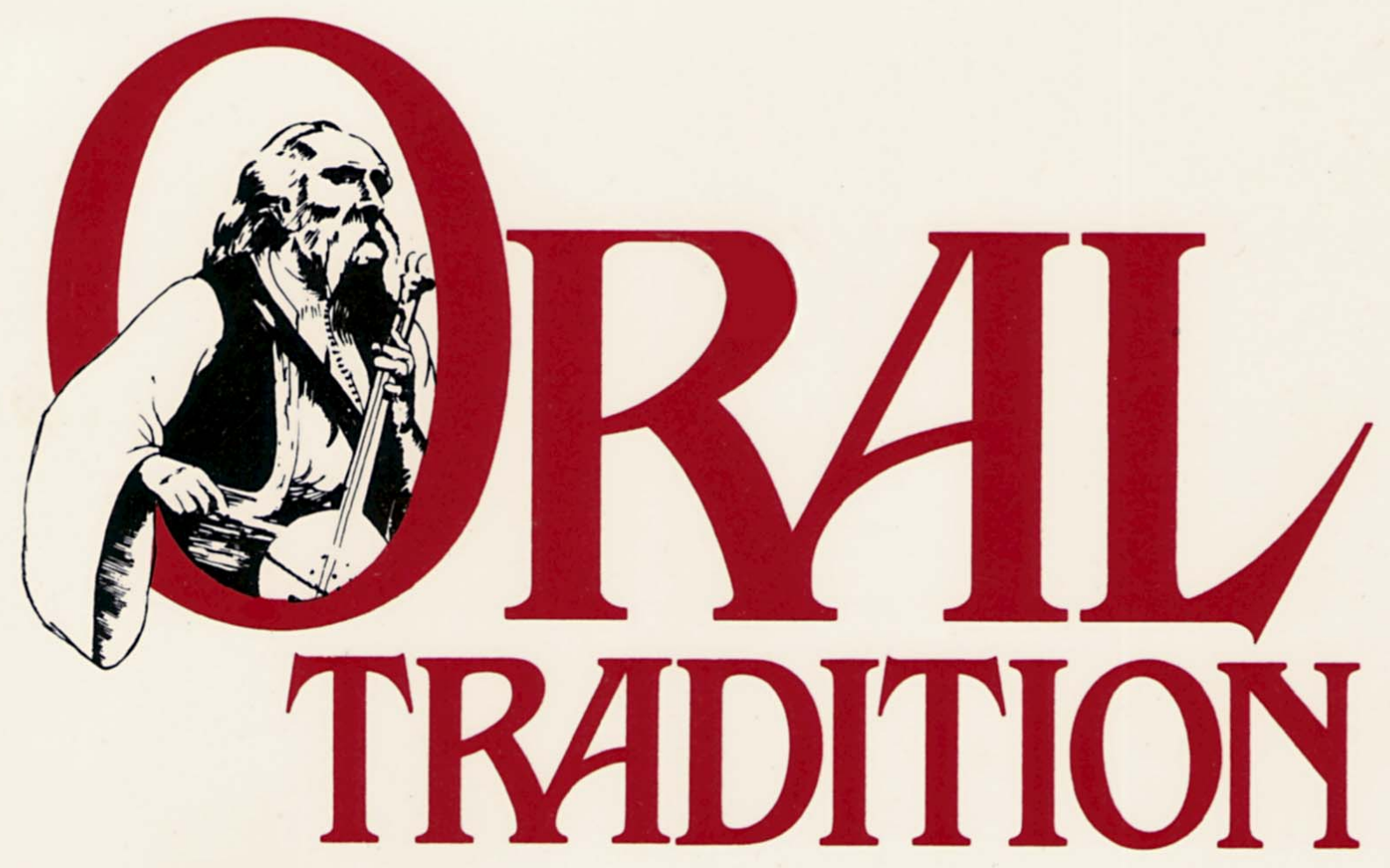

In Memoriam

John Miles Foley

January 22, 1947-May 3, 2012

Volume 27, Number 1

March, 2012 


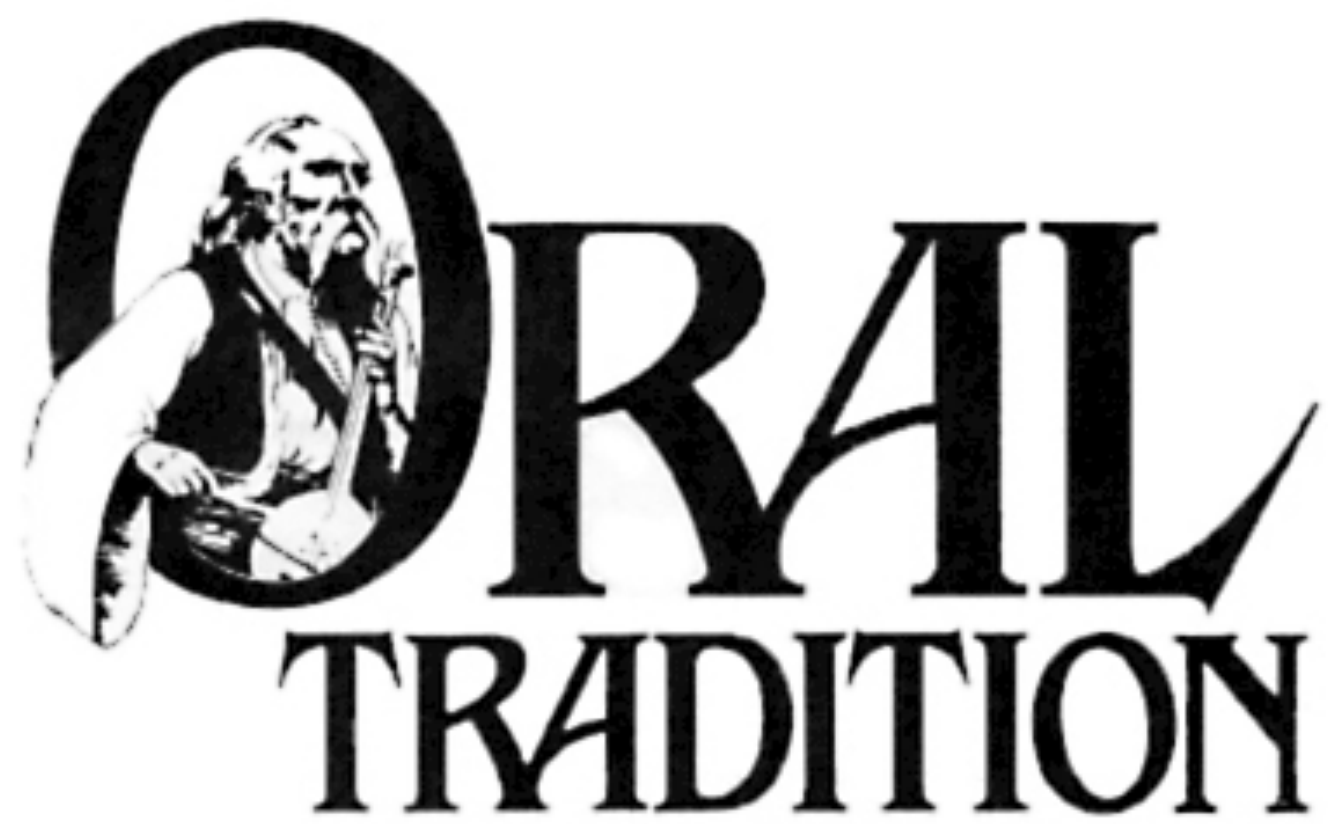

Volume 27

March 2012

Number 1

Founding Editor

John Miles Foley ( $†$ )

Editor

John Zemke

Associate Editors

R. Scott Garner

Lori Ann Garner

IT Manager

Mark Jarvis
Managing Editor

Justin Arft

Editorial Assistants

Morgan Grey

Rebecca Richardson Mouser

Ruth Knezevich

Associate Editor for ISSOT

Darcy Holtgrave 


\section{Please direct inquiries to: \\ Center for Studies in Oral Tradition \\ University of Missouri \\ 243 Walter Williams Hall \\ Columbia, MO 65211 USA \\ $+573.882 .9720(\mathrm{ph})$ \\ +573.884 .0291 (fax) \\ journal@,oraltradition.org}

\section{E-ISSN: $1542-4308$}

Each contribution copyright (C) 2012 by its author. All rights reserved.

The editors and the publisher assume no responsibility for statements of fact or opinion by the authors.

Oral Tradition (http://journal.oraltradition.org) seeks to provide a comparative and interdisciplinary focus for studies in oral tradition and related fields by publishing research and scholarship on the creation, transmission, and interpretation of all forms of oral traditional expression. In addition to essays treating certifiably oral traditions, $O T$ presents investigations of the relationships between oral and written traditions, as well as brief accounts of important fieldwork, and occasional transcriptions and translations of oral texts. In addition, issues will include the annual Albert Lord and Milman Parry Lecture on Oral Tradition. Submissions should follow the list-of-reference format (http:// journal.oraltradition.org/files/misc/oral tradition formatting_guide.pdf) and may be sent via e-mail (journal@oraltradition.org); all quotations of primary materials must be made in the original language(s) with following English translations. If appropriate, please describe any supporting materials that could be used to illustrate the article, such as photographs, audio recordings, or video recordings. Oral Tradition publishes such materials online in an eCompanion designed to supplement the texts of articles. Most contributions will be reviewed by at least one specialist reader and one generalist reader before a final decision is reached.

Oral Tradition appears twice per year, in March and October. The current issue and all back issues from 1986 onward are available open-access and free-of-charge at http:// journal.oraltradition.org. 


\section{EDITORIAL BOARD}

Mark C. Amodio

Vassar College

Old and Middle English

Patricia Arant

Brown University

Russian

Samuel Armistead

University of California/Davis

Hispanic, Comparative

Richard Bauman

Indiana University

Folklore, Theory

Dan Ben-Amos

University of Pennsylvania

Folklore

Mark Bender

Ohio State University

Chinese

Mary Ellen Brown

Indiana University

Folklore, Balladry

Chogjin

Chinese Academy

of Social Sciences

Mongolian, Chinese

Bridget Connelly

University of Cal./Berkeley

Arabic

Robert P. Creed

Univ. of Mass./Amherst

Old English, Comparative

Robert Culley

McGill University

Biblical Studies
Thomas DuBois

University of Wisconsin

Scandinavian

Joseph J. Duggan

Univ. of Cal./Berkeley

French, Spanish, Comparative

Alan Dundes ( $\mathbf{\dagger})$

Univ. of Cal./Berkeley

Folklore

Mark W. Edwards

Stanford University

Ancient Greek

David Elmer

Harvard University

South Slavic, Ancient Greek

Ruth Finnegan

Open University

African, South Pacific

Joxerra Garzía

University of the Basque Country

Basque

Andrew Gerstle

University of London

Japanese Theater,

Performance Literature

Terry Gunnell

University of Iceland

Old Norse, Drama

Thomas Hale

Penn. State University

African

Lee Haring

Brooklyn College, CUNY

African 
Joseph Harris

Harvard University

Old Norse

Lauri Harvilahti

Finnish Literature Society

Russian, Finnish, Altai

Lauri Honko (†)

Turku University

Comparative Epic

Dell Hymes (†)

University of Virginia

Native American, Linguistics

Martin Jaffee

Hebrew Bible

Univ. of Washington

Minna Skafte Jensen

Odense University

Ancient Greek, Latin

Werner Kelber

Rice University

Biblical Studies

Françoise Létoublon

Université Stendahl

Ancient Greek

Victor Mair

University of Pennsylvania

Chinese

Peter Middleton

University of Southampton

Contemporary Poetry

Performance

Nada Milošević-Djordjević

University of Belgrade

South Slavic

Stephen Mitchell

Harvard University

Scandinavian
Gregory Nagy

Harvard University

Ancient Greek, Sanskrit,

Comparative

Joseph Falaky Nagy

Univ. of Cal./Los Angeles

Old Irish

Susan Niditch

Amherst College

Hebrew Bible

Walter J. Ong ( $\dagger$ )

St. Louis University

Hermeneutics of orality and literacy

Shelly Fenno Quinn

Ohio State University

Japanese

Burton Raffel

Univ. of Southwestern

Louisiana

Translation

Karl Reichl

Universität Bonn

Turkic, Old and Middle English

John Roberts

Ohio State University

African-American

Joel Sherzer

University of Texas/Austin

Native American, Anthropology

Joseph Sobol

East Tennessee State University

Storytelling

Dennis Tedlock

SUNY/Buffalo

Native American 
J. Barre Toelken

Utah State University

Folklore, Native American

Ronald J. Turner

Univ. of Missouri/Columbia

Storytelling
Andrew Wiget

University of New Mexico

Native American

Paulu Zedda

Università di Cagliari

Sardinian 
This page is intentionally left blank. 


\section{In Memoriam}

\section{John Miles Foley}

January 22, 1947-May 3, 2012 
This page is intentionally left blank. 


\section{Contents}

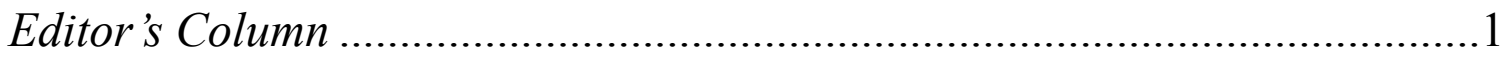

Slavica Ranković

Managing the "Boss": Epistemic Violence, Resistance,

and Negotiations in Milman Parry's and Nikola Vujnović's

Pričanja with Salih Ugljanin ....................................................................5

Ingrid Åkesson

Oral/Aural Culture in Late Modern Society?

Traditional Singing as Professionalized Genre

and Oral-Derived Expression

Katherine Campbell

Masonic Song in Scotland: Folk Tunes and Community

William Lamb

The Storyteller, the Scribe, and a Missing Man:

Hidden Influences from Printed Sources in the Gaelic

Tales of Duncan and Neil MacDonald....

Emily Lyle

Stepping Stones through Time

Cathlin Macaulay

Dipping into the Well: Scottish Oral Tradition Online

Sabine Dedenbach-Salazar Sáenz

"Our Grandparents Used to Say That We Are Certainly

Ancient People, We Come From the Chullpas":

The Bolivian Chipayas' Mythistory

Mark Bender

Butterflies and Dragon-Eagles:

Processing Epics from Southwest China

Editorial Staff

"With This Issue . . ".: A Record of Oral Tradition

About the Authors 
This page is intentionally left blank. 


\section{Editor's Column}

This column marks an unwelcome first for Oral Tradition, unwelcome though inevitable. John Miles Foley founded the journal in 1986 and edited it for 26 years. The last two of these John mounted a heroic resistance keeping disease at bay long beyond the initial prognosis; that struggle ended May 3, 2012. His absence has left those who knew John or engaged him through his writing deeply saddened. Though death has taken a reliable guide whose vision swept far along the horizon, solace may yet be taken in the example John set and the certain knowledge that his life's work has bequeathed an enduring legacy and a compelling incentive for future advances. John's soft-spoken manner, unfailing kindness, and genuine collegiality-my own debt to him remains outstanding - cloaked an indomitable spirit unvanquished by adversity, no matter its form. Homeric tradition epitomizes this aspect of John's courage with Hector's vow to

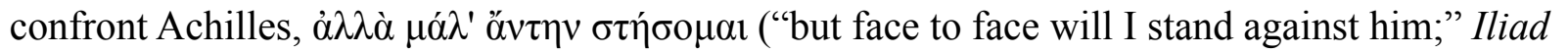
XVIII.306-07), while the diction of South-Slavic tradition confirms the ironic truth, Ni od puške, ni od noža, no od Boga, staroga krvnika ("Not by rifle, nor by knife, but by God, the old executioner;") (Ranković, infra, p. 50).

For more than a quarter of a century, Oral Tradition has hosted an ongoing conversation sustained by you, its authors and readers. This journal draws its strength from the collective effort of your participation in that discussion. Let me therefore extend an invitation to continue this time-honored collaboration. As always, the journal seeks articles that challenge conventional thinking and received wisdom, provoke new questions or essay novel responses to old questions, and offer insights into the multifaceted forms, operations, and meanings conveyed by traditional verbal arts in human societies. Entrusting your work to this journal ensures that it enjoys a full hearing from specialist and generalist readers, receives meticulous attention from the editorial staff, and is distributed internationally in electronic form without cost.

The present issue begins with Slavica Ranković's stimulating exploration of the performative aspect of twelve days of recorded conversations between Milman Parry, Nikola Vujnović, and Salih Uglajanin (and to a far lesser extent Albert Lord). This fine work of discourse analysis details a clash of cognitive systems while underlining how the unstable balance of discursive power shifted repeatedly between the interlocutors along and against linguistic, cultural, and economic fault lines.

The next five articles form a cluster, representative of work presented at the November 5-7, 2010, Colloquium "Oral Culture-The Difference it Makes," which was organized by Katherine Campbell and Emily Lyle of the Department of Celtic and Scottish Studies at the University of Edinburgh. John Foley gave the Sir Everard im Thurn lecture, the colloquium's opening address.

In the first essay of the cluster, Ingrid Åkesson casts an ethnomusicologist's eye on the transformation of traditional Swedish singing. She looks at how the revival and institutionalization of a diminished living tradition effect changes in vectors of transmission, 
singing techniques, aesthetic ideals, performance locales, and singing itself as an identity marker.

Katherine Campbell considers the historical role of Masonic songs in Scotland, the communal and ritual context of song circles, and the songs' cohesive capacity to imprint shared identity on the singers, or in Campbell's phrase "to pledge allegiance to the group." An account of songs' ritual significance for Masonic processions and concomitant appeal to the wider community closes this study.

William Lamb addresses the curious case of Duncan MacDonald and his brother Neil McDonald, Scots tradition bearers, as well as Donald John MacDonald, Duncan's son. The curiosity resides in the nearly identical wording of tales told first by Duncan then ostensibly told twenty years later by Neil, with versions taken from the latter being nearly identical to those taken from the former twenty years earlier! The near identical wording was long considered the hallmark of a highly conservative tradition, but Lamb's analyses uncover seemingly irrefutable statistical evidence of plagiarism as well as of visual copying on the part of Donald John MacDonald, one of twentieth-century Scotland's finest poets.

Emily Lyle delivers a new perspective on the hybrid nature of Indo-European prehistoric cosmology, linking conceptions of generational memory with kingship rules. Generational kingship rules prescribe that each king marry the daughter of his predecessor, alternating between white and red lineages in a 24 year cycle. The model proposes a four-generation memorable human time span, a "memory-capsule," that shifts forward one move with each new generation, the most remote ancestors being undifferentiated by the newest generation.

Cathlin Macaulay completes the cluster with an essay that rehearses the history of collecting, archiving, and disseminating Scots oral traditions from the mid-eighteenth century up to and including establishment of the School of Scottish Studies in 1951. Dedicated initially to "rescue ethnology," preserving the last vestiges of age-old traditions disappearing under the relentless pressure of modernization, the School's collecting, conservation, and archiving activities amassed thousands of sound files as well as films, videos, photographs, and other materials. These sound materials, as well as those of two more important archives, are now available online in digitized form through the Toba an Dualchais/Kist o Riches project. Macaulay explores the difficulties archivists face classifying materials, transferring between media, and then closes by offering a tale told by Norman MacQueen of St Kilda in 1961, Dùgan is Fearchar Mòr ("Dugan and Big Farquhar").

Sabine Dedenbach-Salazar Sáenz offers an analysis of cosmogonic and cosmological tales told by the Chipaya people, a minority isolated on the Bolivian Altiplano among the Quechua and Aymara majorities. The historical complexity of Andean societies emerges from analysis of myth-history and surnames that lays bare questions of identity, legitimacy, and land rights. The Chipayas' stories depict moves from conciliation to confrontation, and reveal the protean nature of oral traditions as it attends to current concerns and requirements, revealing myths as flexible and practical narratives. 
Mark Bender delivered the twenty-fifth annual Albert Lord and Milman Parry Lecture on February 10, 2011, at the University of Missouri-Columbia, and it is presented here in a revised version. This study documents the vicissitudes lived by guardians of the Miao ethnic group's oral traditions and considers closely one of their myth-epics, "Butterfly Mother." Together with the description of a Nuoso bimo priest performing the creation myth, "Dragon-Eagles," Bender's presentation of a portion of his field notes underscores the essential role local researchers play contextualizing and explicating their culture, and contributing to the larger project of preserving intangible culture.

Finally, the Editorial Staff presents excerpts from 29 of John Miles Foley's editorial columns. This compilation highlights major goals, accomplishments, and shifts in the journal's development and proffers a concise and eloquent narrative account of the intellectual pathways on which the founding editor and the journal's multiple contributors travelled together.

This issue sees the light of day thanks to the unstinting efforts of the editorial staff, chiefly and principally those of the Associate Editors, Lori Garner and Scott Garner. Lori and Scott have undertaken to maintain day-to-day operation of the journal while attending to their full-time academic and administrative duties at Rhodes College. They have shouldered the burden of keeping everything moving forward on schedule, and the machinery is in good working order. Their knowledge, professionalism, and unselfishness merits much kudos and many thanks. Mark Jarvis, the Centers' Information Technology specialist, helps to lighten the load, delivering sage advice with unflappable good sense. Justin Arft deftly coordinates the efforts of our current editorial assistants, Morgan Grey, Rebecca Richardson, and Ruth Knezevich, and maintains communications along the production line. Besides overseeing several Center undertakings that in their proper season should bear fruit, Darcy Holtgrave makes plain sense out of what is otherwise garbled and misshapen. Finally, the indispensable Hannah Lenon ably administers all of the Centers' affairs. I thank them all for their good cheer and patience as well as forbearance with my own shortcomings.

An expression of my gratitude is owed to Michael O'Brien, Dean of the School of Arts and Science of the University of Missouri-Columbia, who provides the necessary support for the Center for Studies in Oral Tradition to do its work. I am similarly indebted to all of the readers who have evaluated manuscripts, taking time from their own duties to share their expertise with the staff and our contributors. Guidance received from the Editorial Board has been crucial to decisions regarding submissions. It is a great pleasure to take advantage of these good colleagues' wisdom. Over the last six months, I have received many words of encouragement and support from John's friends and they have greatly eased carrying out my new duties. John Miles Foley's legacy may be most profitably advanced by further explorations into the universe of traditional verbal arts. We welcome your submissions to Oral Tradition and look forward to learning from you.

John Zemke 
This page is intentionally left blank. 
Oral Tradition, 27/1 (2012): 5-66

\title{
Managing the "Boss": Epistemic Violence, Resistance, and Negotiations in Milman Parry's and Nikola Vujnović's Pričanja with Salih Ugljanin
}

\author{
Slavica Ranković
}

Without a doubt, Albert B. Lord's seminal work The Singer of Tales owes much of its success to the series of pričanja ("conversations") ${ }^{1}$ conducted with the South Slavic singers in 1933-35 by his mentor, Milman Parry, and his native assistant, Nikola Vujnović. This was an endeavor that Lord initially assisted in and benefited from as a student, and a practice he adopted during his own subsequent research trips to Yugoslavia in the 1950s. Along with the hands-on experience of listening to and recording performances of epic songs and other lore, these interviews proved crucial to the forming of the so-called "Oral-Formulaic Theory" inasmuch as they provided vital contextual information, as well as some basic interpretative tools for approaching the sizeable body of recorded epics. Moreover, in the course of the interviews, the singers offered valuable insight not only into what they already knew and did (for instance, how they acquired their skill, how they composed, or what in their opinion counted as a truthful, beautiful, or "correctly" sung tale), but also into what they could know and do, as the interactive and heuristic nature of the interview presented Parry with ample opportunities to test his hypotheses - those that he brought from Harvard and the Sorbonne, and those that were forming and being transformed during the interviews themselves. The ways of thinking that resulted from such probing and experimentation ${ }^{2}$ must to a significant degree account for the applicability and usefulness of the Parry-Lord method beyond the narrowly South Slavic context. ${ }^{3}$ As John Miles

1 The literal meaning of pričanje is "telling." To be sure, translating the word as "conversation" makes it less amorphous and better highlights the envisaged dialogic nature of the event. However, "conversation" is also a rather misleading translation as it connotes spontaneity; it gives a false impression that these were leisurely exchanges among equals, with questions and answers flowing bilaterally. Though in relation to this particular context another available option, "interview," seems too technical and even somewhat anachronistic or anatopistic, it at least points to the hierarchy at work and thus accounts more accurately for the fact that although the singers do most of the "telling," they are at the same time not the ones in charge of their talk, as this is the privilege of the interviewers.

2 Roman Jakobson (1954:xii) particularly admired Parry's experimental approach and deemed it a feature that distinguished Parry's fieldwork above those of his predecessors and contemporaries.

3 This usefulness, of course, relies on the method being applied sensitively, with an awareness of the specificities of the particular tradition studied. Ruth Finnegan's classic, Oral Poetry: Its Nature, Significance, and Social Context (1992), offers an important corrective in this regard. 
Foley attests (1998:149): "to date more than 100 language areas have been affected by the approach they initiated."

While explored and exploited as a rich resource for learning about oral tradition, the singers' place within it, and attitudes towards it, these conversations are seldom considered as performances in their own right - that is, as meta-performances - that themselves feature the recitation/telling/singing of epic poetry and other traditional lore. ${ }^{4}$ Although they are likely to be as "genuine" as any other interviews (recorded or not), these conversations bear clear signs of staging. To take those with Salih Ugljanin as an example, just before the "official" conversation begins, the faint whispers of Nikola Vujnović's leisurely, often preparatory chatter with the singer can sometimes be distinguished from the crackling background noise of the phonograph already set in motion. So, too, can some of Parry's barely audible interventions and instructions to Nikola be made out in brief pauses, often marking the turning points of an interview; ${ }^{5}$ even amidst apparently impassioned debates, charged with ethnic and religious tensions (e. g., PN 659, VI:47-48, R 1053: 0:51-0:52), ${ }^{6}$ Nikola will not forget to remind the singer, under his breath and fully composed, to voice his contrary opinion glasnije ("louder"). ${ }^{7}$ At other times, the singer himself speaks in a lower voice: when tired or in pain, when insecure, or when he judges the content of his remark as not record-worthy (e. g., PN 654, II:67-68, R 928: 2:19-2:30). In these cases his interviewers rarely follow suit and instead ask him to repeat the remark more loudly, not missing an opportunity, paradoxically, to stage some spontaneity and realism as well.

${ }^{4}$ A notable exception is Elmer 2010.
${ }^{5}$ Nikola tended to include Parry's instructions in the subsequent transcriptions if they were audible enough. (Note that, in addition to acting as an interpreter and mediator for Parry and Lord, Nikola also transcribed the phonographic recordings.) If they were not, either Nikola would indicate by a dotted or a continuous line that Parry had said something, or he would not note it at all (e. g., PN 654, II:15-18 feature all these cases; for the referencing conventions, see footnote 6). The latter case occurs more often when Nikola subsequently repeats Parry's question to the singer in a more or less unchanged form, and there is a strong tendency in the transcriptions of later conversations not to mark these kind of interventions, even when they can be heard (e. g., PN 659, VI:41-46, R 1051-52).

${ }^{6}$ References to the Pričanja with Salih Ugljanin will adhere to the following convention: each Pričanje will be indexed by the Parry archives' catalog number (here PN 659) and the Roman numeral corresponding to the interview cited (here VI). These will then be followed by the transcript page number(s) (here 47-48) and the number of the corresponding audio record(s) (here R 1053). Where the manner in which something is said is of particular importance, the reference will include the minutes and seconds of the cited excerpt (here 0:51-0:52). Since these recordings are freely available online and easily accessible, I will limit audio clips included in the eCompanion to this article to block quotations only. I hope that these excerpts will inspire the reader to explore further this fascinating material.

${ }^{7}$ Nikola's remark is heard here, but it is not included in the transcript. Please note that, as a general rule, I will prioritize the recordings over the transcripts, while noting the differences. Also, unless otherwise specified, all translations from Serbian/Bosnian are mine. In particular, when it comes to the Pričanja, I will attempt to follow as closely as possible features of the participants' oral delivery (pauses, ellipses, incongruent grammar, semantic lapses, and so on) in the hope that what such a translation will lose in elegance, it will make up for by better conveying the mood of the speakers and the atmosphere of their exchanges. This decision touches upon important questions regarding the scientific method to which I will come back in the next section- "Staging My Own Staging and the Efficiency of Neglect." 
Casting the conversations in terms of useful, primarily supplementary material ${ }^{8}$ must have obscured, to a significant degree, their performative aspect, as well as rendered all too transparent the otherwise subtle relationships that developed between the collector, the informant, and the routinely neglected third figure that looms large in these recordings, that of the interpreter/mediator. However, one of the more mundane reasons for the conversations' remaining unstudied in their own right must have been the restricted availability of the phonographic recordings to a wider scholarly audience. With the recent establishment of the "Milman Parry Collection of Oral Literature On-Line" (MPCOL) hosted by Harvard University, and their ongoing digitization of Parry's and Lord's recordings, it is becoming more and more possible for scholars around the globe to access some of this material unprocessed and study more closely the intricacies of the ways in which the three ${ }^{9}$ principal actors relate to one another.

The Pričanja ${ }^{10}$ with the singer Salih Ugljanin from Novi Pazar in Serbia offer a wealth of insights in this regard, and the present paper will focus on how the singer copes with, negotiates, sometimes stubbornly resists, and often mirrors what Gayatri Chakravorty Spivak (1988:280 et

${ }^{8}$ As with other singers from Novi Pazar, the translated corpus of Salih Ugljanin's songs is preceded by a large part of Pričanje $I$ by way of introducing the singer. However, Lord consigns ample portions of other conversations to explanatory notes for the published songs, thus stressing their value as supplementary material (SCHS I:330-400). Almost ironically, the notes to the "Conversation (A) with Salih Ugljanin" (329-30) make painfully obvious the fact that this contextual material is itself in need of contextualization and independent study.

9 Even as I speak of the "three principal actors" (because theirs are the voices that can be heard in the recordings and they are engaged in direct contact), I am well aware of the fourth participant, Albert Bates Lord. The silent phonograph operator from the adjacent room, the listener, the witness, Lord will also turn out to be the director of the proceedings, their ultimate presenter, the one in charge of the cuts, appropriation, and the final wrap-up in The Singer of Tales. For this reason he will continue to appear in the following discussion, even though I will mainly focus on Milman Parry, Nikola Vujnović, and Salih Ugljanin.

${ }^{10}$ In addition to the series of six interviews with Salih Ugljanin dubbed as Pričanja I-VI (PN 652, 654-56, 658-59), in this article I will also consider Pjevanje i pričanje ("Singing and Conversing," PN 674), as this interview chronologically follows Pričanje VI and does not generically differ from other Pričanja in which the "singing and conversing" are also intermingled. Because its title could have easily been Pričanje VII and because the present one also reverses the word order in the original transcript title, Pričanje i pjevanje, when the need for an abbreviation arises, I will refer to this interview as "VII." On the other hand, I will not include here an item (PN 280a) designated simply as Pričanje (without an accompanying Roman numeral) because it is not an actual interview, but rather two manuscript pages containing Nikola Vujnović's notes on how the singer explains the similarities and differences between the two songs he recited that day, as well as a brief retelling of a story about Đerđelez Alija and Marko Kraljević. Please note that, with the exception of Pričanje $V$, the transcripts and audio recordings of all the interviews are featured in the "Milman Parry Collection of Oral Literature On-Line" (http://chs119.chs.harvard.edu/ mpc/index.html), which is the main source of all the related quotations in this article. However, the fact that I am still able to include Pričanje $V$ in the discussions to follow testifies to the great dedication, care, and helpfulness on the part of the Milman Parry Collection curatorial staff. I am especially grateful to Dr. David F. Elmer and Peter McMurray who supplied me with the transcript scans of Pričanje $V$ and Pričanje, as well as helped me obtain the necessary permissions to quote profusely from the Collection. Without their kind intervention, this article would have been poorer and drier. 
passim) and others ${ }^{11} \mathrm{dub}$ the "epistemic violence" - an imposition of foreign (scholarly, Western, colonial) terms of engagement that experts of various callings, often inadvertently and with the best possible intentions, nevertheless repeatedly perpetrate against their informants. ${ }^{12}$ In scholarly efforts to engage in a transcultural dialogue - the efforts that constitute the raison d'être of anthropological, folkloristic, ethnographic, postcolonial, and comparative literature studies - the "informant," the "other," still remains to be heard, his or her every utterance subject(ed) to the poetics of the imposed academic discourse. Through such "ventriloquist strategies of representation" (Ritchie 1993:366), the inadvertent and inescapable monologization that irons out the bumps of otherness from the smooth consistency of one's own worldview, these endeavors seem doomed as dialogues from the start. ${ }^{13}$ Indeed, even as I proceed to discuss the epistemic violence of the fieldwork that translated Salih as "informant," "indigene," and "subaltern," the question of my own complicity in this same project arises. Is it not yet more translation that I am about to inflict here?

\section{Staging My Own Staging and the Efficiency of Neglect ${ }^{14}$}

If this were a reflexive and reevaluating piece of ethnographic work intent on setting right what was wronged the first time around, there would be a paradox in purporting to speak for the misrepresented while in the same breath adding yet more layers of presumptuous representation. Even if I could never hope to mitigate the charges of representation in the first place, that this is no such work makes a difference. This is a collection of listening notes where what I listened to you can hear as well, with the sampling fairness and quantized fidelity of a digitized recording.

11 Gayatri Spivak's "Can the Subaltern Speak?" is considered the key text in establishing the study of epistemic violence, more specifically "the narrow epistemic violence of imperialism" that "gives us an imperfect allegory of the general violence that is the possibility of an episteme" (1988:287). This more general notion of epistemic violence, however, originates with Jacques Derrida, whose work greatly influenced Spivak and whose paradigm-shifting book, Of Grammatology, she translated (1997). In particular, in the chapter scrutinizing LéviStrauss's study of the Nambikwara people (idem:101-40), Derrida deals with epistemic violence in both the narrow and general senses. And while in her seminal essay Spivak severely interrogates her other important precursors (for instance, Foucault's decidedly European perspective on "subjugated knowledge"), Derrida remains an important point of reference (Spivak 1988:292): "hard to read" but "less dangerous when understood than the first-world intellectual masquerading as the absent nonrepresenter who lets the oppressed speak for themselves."

12 Note how the very word "informant" connotes subordination and renders the bearer of this label an instrument of the one who has yet to make adequate use of the information provided (that is, the scientist).

13 These problems, as they play out in the area of comparative literature studies and beyond, were the intense focus of the 2006 American Comparative Literature Association (ACLA) Report on the state of comparative literature as a discipline (Saussy 2006), and they were also central to Volume 3, Issue 1-2, of Comparative Critical Studies (2006) and the 2009 issue of New Literary History (Volume 40, Issue 3), both featuring articles written in reaction to the 2006 ACLA Report. For anthropological, ethnographic, and folkloristic perspectives, see, for example, Clifford and Marcus 2010, Ritchie 1993, Vasenkari and Pekkala 2000, and Marker 2003.

14 This section was co-authored with Miloš Ranković in response to the suggestion made by an anonymous reviewer. I wish to thank this perceptive reader for the depth of his or her investment in this project and for many useful comments, constructive criticism, and expressed enthusiasm. This text has changed considerably as a result, and I imagine that he or she would relish the way in which these contributions have further emphasized the nontriviality of the question of who hereby speaks. I thus dedicate this section to these worthy voices. 
The difference this makes is that of a somewhat relaxed concern on my part for the preservation or presentation of anything, still less anyone. Certainly, there is violence-it is the name of the play, after all —except none of the characters that animate my stage, "I", Salih, Nikola, or Parry, hesitates to show their teeth. And even if they only ever bare their teeth in laughter, that reminds me that I am in no place to redress the wrongs of ethnographic fieldwork, let alone to empower the other. As Michael Marker cautions (2003:370):

\footnotetext{
"Empowering" or "advocating" for Indigenous communities is a suspiciously ethnocentric and patronizing goal. Many Indigenous groups would find the language itself offensive and presumptuous since they maintain that they were never conquered and hence have never relinquished their "power."
}

Perhaps more radically still, I do not seek to empower the other because power is never one's own: power is others'. Even as I stage a certain scholarly framework as the source of epistemic violence, it is already I who is framed. Episteme is not what I have to wield or swear by, but rather what has me to do its dirty/cleansing work-I, the scapegoat, better known as the author. Wherever in what follows I detect a symptom of epistemic violence, read that I am confessing my own: not only is this my staging of the Pričanja, but I also recognize so much of Parry's scholarly mannerism as my own. Between my training and my listening, I am much less a source of power than its instrument. As such, these recordings play me instead. They interest me, baffle me, touch me. They trigger my attitudes: personal, professional, epistemic. Inevitably then, as I stage the Pričanja, violence is the theme and the method, yet this is already to thematize the violence of all methods, especially those entrusted to take care of the other (if there is any other kind of method). Of course, if this is the unavoidable predicament of all staging, the question we are obliged to ask is why stage at all? What is the point? To what end? Perhaps, first of all, to worry aloud about all the ends and purposes programmed into methods of scholarly analysis; to stage what by definition cannot be seen, that the very economy of a well rehearsed method (which is the method's own end) resides in the neglect of asking whose purposes and whose ends.

However, while the methods of fieldwork will inevitably be staged as suspect, they will not be my prime suspects. There is certainly much to say about the methods that produce "collectors" and "their informants," but there is probably as much to be said about the theory of epistemic violence and its products. The "Other" and the "subaltern," in particular, are some of the local produce of that theory. Thus I hear bell hooks, that she "was made "other" during her graduate years, in and $b y$ those fields of foreign epistemic investment, whereas "in that space in the margins, that lived-in segregated world of my past and present, I was not 'other" (1999:342). I believe her that "often this speech about the 'other' annihilates, erases" (343), the speech she then goes on to stage as well (343): 
No need to hear your voice when I can talk about you better than you can speak about yourself. No need to hear your voice. Only tell me about your pain. I want to know your story. And then I will tell it back to you in a new way. Tell it back to you in such a way that it has become mine, my own. Re-writing you I write myself anew. I am still author, authority. I am still colonizer the speaking subject and you are now at the center of my talk. [italics in original]

I see that I am staged here in turn, generically speaking. How odd, though, is this true me. How "other" on this stage. How comically as well as tragically stupid I stand on it. I am still colonizer, the well-programmed instrument of colonization. I am still author, the scapegoat. (How interesting, too, is that I sound ironic and defensive here, even though that is certainly not how I feel about bell hooks' staging of my speech: I recognized myself in it well enough.) But I remember, too, growing up in Serbia, back then when there was Tito and Yugoslavia, and all those jokes, so characteristic of small peoples with big national egos, featuring a line-up of fittingly grotesque representatives of "foreign powers" along with a homegrown exemplar. "There was once an American, a Russian, a Chinese," and so on, the joke would go. I remember how power and stupidity seemed to go naturally hand in hand. And I remember the laughs. Perhaps such insubordinate laughter is just the kind of noise that bell hooks tells us is "more often silenced" (342), the din of props coming from another's stage. The following staging of the Pričanja also features some hearty laughs from Salih, Nikola, and Parry, sometimes in unison, though I will save that for the end.

When such ill-mannered noises have been silenced, it may be safe to assume that some scholarly mannerism found itself offended, which is to say that some well practiced method took care of the other without reservation, slipping it into its reserved slot with the satisfying whoosh of no friction, the sound of efficiency and negligence. Which makes me think: how complete and consistent should I want my staging of the Pričanja to be? What kinds of reservation should I keep? And what is this silenced clamor of friction supposed to be in general?

What is silenced precisely by way of methodical generalization is the resistance of the marginalized, as bell hooks explains (342):

I want to say that these margins have been both sites of repression and sites of resistance. And since we are well able to name the nature of that repression, we know better the margins as site of deprivation. We are more silent when it comes to speaking of the margin as site of resistance. We are more often silenced when it comes to speaking of the margin as site of resistance.

Equipped with our universal(izing) theory of otherness, we are well able to name. And the better we are able to name, the less conspicuous is the absence of the named. The other resists the resourcefulness of the "Other" and the efficiency of its theory. Every other is already a capital example of the other inasmuch as it remains after grasping by example. The other cannot be displayed, capitalized on, or manhandled as such, because "there is no Other as such" (Wood 2005:69). We fail others by miss-take, miss-appropriation and miss-management. The following is an attempt to stage the Pričanja featuring not Salih the subaltern, still less Salih the informant, but this Salih Ugljanin from Novi Pazar who is both 67 and 85 years old, and who both does and does not know a song in which a Serbian hero prevails. It is that Salih whom I have never quite 
managed to characterize and who never tires of rearranging the propositions of my stage when I do not look. Wherever there is indecision, incompleteness, or inconsistency in my argument, read that beyond the scholarly incompetence it may be Salih and company insisting on their absence to be marked, insisting that their tale is not yet complete, insisting on their being in-decision.

But how am I to take care of such heterogeneous others? What would be a good method? To be sure, I cannot let (the words of) these others speak for themselves. I cannot even hear them speak for themselves any more than I can write/think about them in the homogenous unity of my "own" copyrighted words. I have heard them speak, though. It is too late now to pretend that I have not, that I read their text instead. So whenever in what follows academic propriety is offended by unscientific accounts of emotional prosody, with adjectives, adverbs, and other modifiers shamelessly staging the words of the other, read that I confess to having heard voices. Read too that "their" words, purged of "my" modifiers, would have been a staging still more dangerous, silent. ${ }^{15}$ At any rate, the finality of my representation is offset by the uncommon accessibility of the voices I heard. To draw attention to the potential value of this rare luxury was my first motivation to stage the Pričanja. Here, for the moment, we are listening to me listening to them listening to each other. If there is any interest in participating in this game of Chinese whispers, let it be to try and measure (up to) these distances and the value of participation, whether it is worth the violence of touch and the risk of entanglement.

\section{Parry's Scholarly Safari}

It is certainly not hard to find the idea of epistemic violence within the context of Milman Parry's fieldwork in Yugoslavia during the 1930s. Indeed, there is a strong parallel between scholarly expeditions of the kind Parry undertook and safari expeditions, colonial narratives, and movies: a young, white, middle-class Westerner (just as the cliché has it) goes off to explore an exotic culture. He does not do this out of a genuine curiosity about Yugoslavia, at least not at first, but for what its backwardness (or, cast in more positive and more patronizing terms, its still lasting golden age of cultural innocence) can teach him about a far greater civilization, the one whose intellectual heir he considers himself to be, that of Homeric Greece. Subsequently, after the South Slavic songs - and the region's oral tradition in general-became passions in themselves and not merely the stepping stones on the way to understanding orality in Homer, Parry reminisced about his initial intentions as follows (quoted in Lord 1954:3-4):

\footnotetext{
It was least of all for the material itself that I planned the study. . . . Of the various oral poetries for which I could obtain enough information the Southslavic seemed to be the most suitable for a study which I had in mind, to give that knowledge of a still living oral poetry which I saw to be needed if I were to go on with any sureness in my study of Homer.
}

Decades later, Lord would still need Homer to justify his study of the South Slavic tradition. Lest the audience worry that his book reflect too parochial an interest and the songs discussed be too

\footnotetext{
${ }^{15}$ For an example of a silent staging of Salih Ugljanin's speech, see footnote 120.
} 
mediocre, the first sentence of his "Foreword" to The Singer of Tales reads as follows (2000 [1960]:xxxv): "This book is about Homer. He is our Singer of Tales." (As a subtle counterweight to this statement, however, the picture of the singer Avdo Međedović was placed upon the cover of this new edition.) The subsequent sentences of the "Foreword" try to make some room for the South Slavic singers in the heart of the reader (after all, they and not Homer, the declared subject, will pervade every page of the book), but the estimated price of the reader's affection is the relegation of the South Slavic singers (even the lauded Avdo Mededović) to the position of modern Homeric surrogates whose song-making techniques can brightly illuminate the art of the long-gone genius, even if their end products fade in comparison.

Parry set off on his journeys well prepared, having mastered some Serbo-Croatian. On his second trip in 1934, he also took with him a student assistant and a state-of-the-art, custom-made phonograph, a nifty, if oftentimes annoyingly cumbersome gadget, bound to fill the natives with awe. ${ }^{16}$ "His enterprising spirit was admirable, his recording equipment excellent," writes Roman Jakobson in his tributary "Preface" (1954:xi) to Serbocroatian Heroic Songs $I .{ }^{17}$ As every hero of a safari expedition, Parry, too, had been in need of a reliable native guide, and he found him in the young Herzegovinian singer (and stone mason) Nikola Vujnović, a man well versed in oral culture who could recognize a good song, yet also literate enough to serve as a scribe. For the next two years, Nikola would be Parry's assistant, mediator, interpreter, and, as it happened, an enthusiastic and talented apprentice. ${ }^{18}$ He would take care of the practicalities, conduct most of the interviews following Parry's instructions (but would also invariably take his own initiative), write down the poetry dictated by the singers, and undertake the long and arduous work of transcribing the recordings from the aluminum disks. Following Parry's untimely death in 1935,

16 As Matija Murko testifies from his own field experience in the same region (1951:23): Vijest, da će biti fotografirani i fonografirani, pravila je čuda, kao i to, da će dobiti svoju sliku i čuti svoj glas ("The news that [the singers] would be photographed and phonographed worked wonders, as well as that they would receive their photograph and hear their own voice"). See also Tate 2010:314-15 for an eyewitness account of Parry's arrival in the Croatian village of Kijevo and the villagers" "shock" "when the two foreigners played the recording of Cicvarić's singing" back for them. On the other hand, Albert Lord's impression was that a town dweller is much more easily awed by such gadgets than the singer (1954:11): "In this matter indeed the singer is far more sophisticated than the urbanite, because he is less self-conscious. He is a trained performer to whom public appearance is nothing extraordinary. He is flattered by the recording, but he frequently listens to it without comment, except perhaps to marvel at the wonders of modern science." While there is no reason to doubt the accuracy of Lord's observations, his explanation of the phenomenon (that is, that a singer is "less self-conscious") can be disputed, or rather turned around, to suggest that it is precisely because the singers were more self-conscious that they showed less reaction. In other words, they may have been too proud to show themselves easily excitable and ignorant, and they wanted to preserve their dignity in front of a foreigner. Conversely, in reacting strongly, the urbanite better signals his appreciation of, his cultural allegiance with, and an aspiration towards the world that the gadget represents.

${ }^{17}$ Henceforth, I shall refer to this volume as SCHS I.

18 While both Milman Parry and Albert Lord warmly acknowledge their debt to Nikola Vujnović's talent and versatile abilities (SCHS I:10-11), subsequent scholarship has failed to take enough notice of Vujnović's contribution to the Parry-Lord theory of oral composition. However, recent years are witnessing a change in this regard. See, for example, Foley 2005:235 where Parry, Lord, and Vujnović are referred to as a "research team." See also Foley 2004 and Tate 2010. 
he would continue to transcribe for Lord until World War II swallowed him, leaving no trace as to the kind of fate he met. ${ }^{19}$

Thus armed with knowledge, enthusiasm, hypotheses, awesome gadgetry, an apt pupil, and a nimble native, Parry spent about twelve days in November 1934 in the company of an old Albanian singer, Salih Ugljanin from Novi Pazar in southwestern Serbia. From the resulting series of "conversations" it is obvious that this was not their first encounter (they had already collected some poetry from him earlier in July 1934), ${ }^{20}$ but it does seem to have been the first time Parry was able to conduct and record such a long, sustained, and comprehensive series of interviews with him. These interviews yield a wealth of insight into the singer's biography, artistic practice and abilities, repertoire, and sources, as well as an abundance of epic poetry, legends, humorous stories, ethnographic information, and other lore. However, far from being a neutral means for obtaining information, the Pričanja are also sites of subdued - though at times also vehement - power struggles, clashes of interests, and differences of intention among the three people directly involved. While the overarching love of epic acts as a powerful leveler of their social, ethnic, religious, and age differences, at times it only thinly conceals their very particular and different ways of loving epic. Salih, for instance, likes his songs because they speak eloquently to his sense of identity. Nikola loves Christian epic songs, and Salih's are enjoyed almost as inverted mirrors: the epic landscape, the cast of heroes, the patriarchal ethos, and the hoard of well-known idiomatic phrases are all there, familiar and comforting, yet it is the Muslims who win the day — not his fellow Christians. Parry loves the epics of Classical Greece, and Salih's songs are for him primarily a means of gaining access to the pulleys and levers of oral composition that he believes underlie Homeric epics. The love is there, but as the saying and its parody go (and both get it right), love is a many-splendored and a many-splintered thing all at once.

Through the understated yet understood and undisputed social superiority of the interviewers, the patronizing efficiency of handling the singer as test subject, and the physical as well as mental strain of the tests, Salih's role in these interviews in many ways chimes with the subaltern other: speaking yet dispossessed of voice, his actions directed, his life story collected. While this much fits the theory, there is much else that does not. For example, this was not the first time that this singer of great local renown had encountered a learned collector eager to study

19 Unlike Nikola, the ancient Salih seems to have lived to see the end of World War II. Albert Lord, for instance, mentions (SCHS I:54) that when he visited Novi Pazar in 1950, the singer Mustafa Rebronja told him how Salih died "something more than five years earlier," that is, in 1945 or perhaps late 1944. In either case, the town was liberated in the autumn of 1944, which makes it likely that the singer survived the war, even if only just. With this hindsight, it is rather poignant to hear him note to his young interviewer (PN 656, IV:64, R 990): Kad je ćojek mlad on vara se. On misli ovako ka ti, on neće umrijet nikad ("When a man is young, he deceives himself. He thinks, just like you, [that] he will never die").

${ }^{20}$ A possibility that the trio also met an entire year earlier (1933) is suggested when Nikola asks the singer (PN 652, I:45, R 870): Od koga si čuo tu pjesmu, koju si kazivo lanjske godine, kako je došla četa do Kolašina $i$ pogubila jednoga turčina, $i$ osvetio ga brat? ("From whom did you hear that song, which you recited last year-how a band came to Kolašin and killed one Turk, and his brother avenged him?"). However, the singer's subsequent identification of the song as the one about Kajović Mujan — and the fact that no record of Parry's 1933 visit to Novi Pazar exists - makes it more likely that this was, in fact, a slip on Nikola's part. He probably meant to say "earlier in the year" since Salih had indeed dictated the song now entitled "Kajović Mujan i Periš kapetan" to Nikola on 24 July 1934 (PN 278a). 
his art of making oral poetry, and neither was it the last. Four years earlier, in 1930, Salih met the Prague-based Slovene scholar Matija Murko, ${ }^{21}$ and he was also interviewed again three years after Parry, this time by the famous German Slavist Alois Schmaus. ${ }^{22}$ And while the position title of "informant" was not entirely foreign to Salih, Parry's braving the world of ancient customs and little known dialects as well as the world of novel fieldwork methods meant treading a very foreign ground. ${ }^{23}$ As such, even before my stage production gets under way, my protagonists already resist compliant fieldwork role-playing. And they will continue to resist it as the balance of power between the participants shifts and fluctuates in the course of the interviews.

\section{Sliding Hierarchies, Shifting Allegiances}

\section{Parry as the "Boss"}

That the Pričanja are not conducted among social equals is apparent from the very way the three people address each other. Parry calls the singer by his first name and often refers to him - in his presence and in the language he can understand - in the third person, delegating his questions to Nikola (PN 652, I:16, R 862: 1:07-1:15): Ali pitaj mu što je radijo . . ("But ask him what he was doing ..." ). ${ }^{24}$ Out of context, this indirect form of address may strike one as bordering on rude, alienating and objectifying the singer. However, it is conditioned by the nature of the setup (the scientist endeavors to be "impartial" and to "remove" himself from the experiment as much as possible) and also driven by the practicalities (Nikola and the singer are closer to the microphone and Parry entrusts Nikola to better convey his requests to the singer). At the same time, it is the very nature and choice of this setup that gives Parry the slightly ominous, behind-the-scenes presence of a master puppeteer, his directions all the more potent for coming across as barely audible whispers. Of course, the aforementioned distance from the microphone

${ }^{21}$ As Parry duly acknowledged, it was Murko who inspired him to undertake a research trip to Yugoslavia in the first place (see, for instance, SCHS I:3). Murko had already trodden more or less the same track as Parry in 1930-32 and had, a couple of decades before The Singer of Tales, published some of the results of this fieldwork as well as his own sketchy thoughts on oral-formulaic composition (1932-33; 1933; for Lord's acknowledgement of Murko as "a true pioneer," see 2000[1960]:280). Originally written in Czech, Murko's magnum opus was first published in Croatian translation some years later under the title Tragom srpsko-hrvatske narodne epike: Putovanja $u$ godinama 1930-1932 (1951; see the short introductory note by Antun Barac, the book series editor). Unfortunately, to this day, his work remains largely unknown beyond the specialists in South Slavic studies. The late, founding editor of the present journal was one of the few scholars to have invested some time in addressing this loss by translating some of Murko's work into English (Murko 1990).

22 See Schmaus 1938.

${ }^{23}$ For this perspective on Parry's fieldwork, see, for example, Parry 1971:xxxvi.

24 Here (and as a general rule) I am strictly following Nikola's transcript, which means that I am reproducing both Parry's grammatical error (using the dative instead of the accusative form of the pronoun on ("he") and Nikola's orthographical error of inserting " $\mathrm{j}$ " in radio (this at least according to the current orthographical rules of the standard Serbian language). It is interesting to note that Lord edits Parry's remark out of his translation of Pričanje I; see SCHS I:62. 
could in part account for this effect. However, as some of the quotations cited below will testify, the fact is that Parry had no difficulty making himself heard whenever that was his intention.

When not directly spoken to, the singer likewise refers to the collector in the third person, but with a marked difference: by invoking not the collector's name, not even his surname, but rather the honorific gazda ("boss;" e. g., PN 655, III:106, R 966), or gospodin (“mister;" e. g., PN 656, IV:58, 79, R 989, 994; PN 659, VI:4, R 1042), thus accentuating Parry's higher social standing. Again, practicalities and cultural assumptions are involved that complicate this obvious difference. For one, the singer would have most likely found it ridiculous or even uncomfortable to be called "Mr. Ugljanin," although a good part of this discomfort would have resulted precisely from his awareness that his status as an illiterate peasant and a laborer did not quite agree with the title of a "mister," or gospodin, which, in direct opposition to seljak ("peasant," "villager") connotes an educated, urban man —-well off, usually dressed in westernized attire-a term that, when thus applied, would have felt more like mockery to him than a mark of respect. As for "Ugljanin," the word is not exactly a surname as such but rather a designation of the village (Ugao) from which the singer hails. Thus, in addressing Salih by his first name, Parry does nothing but follow the local social norm of the kind of egalitarianism peculiar to patriarchal communities. Equally, Salih may have opted for the honorific because it was preferable to twisting his tongue around a strange name, and there would have been an additional awareness by the singer of Parry as the foreigner in charge, the one paying for all the tea, tobacco, and daily allowances.

On the other hand, being the "boss" has its own distinct disadvantages in the present context. Assumptions about the unquestioned privilege of the one in charge make it very easy to miss how in certain situations the title of "boss," for all the social deference it connotes, inflicts on its bearer a violence of its own. Calling someone a "boss" is not only conceding the higher social ground, but also an expedient way of putting him in his place, keeping him on the other side of intimacy, which is the staple of any real conversation. Furthermore, in a tradition with such a strong penchant for humorous stories about a poor but witty man getting the better of the high and mighty (consider the stories about Ero and Nasradin-hodža), ${ }^{25}$ being called gazda and gospodin has its ambiguities and potential pitfalls. The same words might have different meanings, depending on whether the singer uses them while in the company of the researchers or when alone with his neighbors and fellow singers.

Most likely, Parry does not object to the way Salih refers to him partly because the singer never addresses him directly in this way, and partly because, as said before, he does not want to interfere with the local customs; nevertheless, it is hard to imagine that the scholar could have actually enjoyed it. In the interviews he comes across as a modest and moderate person, likely to

25 Ero/Hero is a humorous abbreviation of Hercegovac (a man from Herzegovina), but through frequent migrations in the Balkans, it eventually came to signify a peasant from around Užice in southwestern Serbia. In the tradition Ero always outwits his adversaries, most often the Turkish overlords, but also priests, judges, and various other higher-ranking people (cf. Karadžić 1870). Ero's Muslim counterpart is Nasradin-hodža, a comical hero from Turkey (Nasreddin hodja) who, transplanted from his native milieu, found a most appreciative and enthusiastic audience in the Balkans, among both the Muslim and Christian populations. Salih also knew stories about this character and related them to Parry and Nikola in Pričanje $V$ (77-89, R 1023-26). The earliest and the most comprehensive collection of stories about Nasradin-hodža in the region to date (both translated from the Turkish and those originating in the Balkans) was published by the Serbian realist writer Stevan Sremac (1894). 
have brought with him his own brand of egalitarianism - that of the university campus. On the contrary, one could sooner picture him waving an imaginary hand in denial and repeating (inwardly) the cliché of colonial benevolence: "No, not the boss! I am a friend. I come in peace." Suspect speculations aside, one must not lose sight of the fact that, out of the three, it is Parry's name that suffers the most violence in translation, as it is paraphrased in terms of a social role and thus reduced to a mere function. This "other side" to being the boss will soon be explored in more detail. For now, it is of primary importance to emphasize that the very lack of options for equal address already stratifies the social situation in which, with the best possible intentions, the singer and the collector encounter one another.

The relations are less severely imbalanced when it comes to the methods of address between the collector and the interpreter, but they are imbalanced nevertheless. While throughout the interviews Parry calls Nikola by his first name, as would befit two men of similar age and involved in a common undertaking, Nikola does not reciprocate. In fact, he cannot be heard addressing Parry by any sort of name in these particular recordings — at least not directly. Here, too, we encounter explanations of a practical nature, but also the politics that underpin the "practical," in spite of the concept's implicit claim of neutrality and triviality. Having ceded to Nikola the role of the leading interviewer but not that of the project leader, Parry is occasionally forced to step in, interrupt, correct, or curb Nikola, which requires that he address him by name and then follow it with imperatives (PN 652, I:58, 164, R 874, 905): Čekaj Nikola. Pitaj ako je ćuo pjesmu. .. . ("Wait, Nikola. Ask if he had heard the song. . . ."); Eh Nikola, sad pitaj samo za te riječi. Eh. Jesili, ja mislim, da si ti pisao riječi, jeli koje nijesi razumijo? Kad je pjevač pričao tu pjesmu. E pitaj onda da znamo ("Eh Nikola, now just ask about those words. Eh. Did you . . . I think you wrote the words . . . were there some you did not understand? When the singer told that song. Well, ask then so that we know"). Conversely, this situation does not require Nikola (who is completely focused on the singer) to address the collector by name in turn, but rather simply to respond by obeying or ignoring the request, depending on how firmly, loudly, confidently, or persistently it is being posed. ${ }^{26}$

However, the lack of direct oral address is compensated for in the transcripts by Nikola's habitual ways of denoting the three speakers, which reveal his assumptions about the social hierarchy at work and perhaps an awareness of cultural differences with regard to the appropriate forms of address. While Salih's and his own speeches are marked with the initials of their first names only ("S" and "N" respectively), Parry's are preceded either by his full initials "M. P." or by his academic title and the surname "P. P." 27 However, one interesting and persistent phenomenon in this context is the appearance of Nikola's signatures in the margins of the transcripts. From bell hooks's perspective on margins as sites of resistance, it becomes rather interesting to consider the frequency and variety of ways in which Nikola signs his name as

${ }^{26}$ In the above-quoted passage (PN 652, I:164, R 905) when Parry asks Nikola to inquire from the singer about the meaning of the unknown words from the song about Golalija, Nikola proceeds to do it. However, a careful listener will remember that Parry already asked this earlier, though not very loudly, leaving Nikola to proceed with his own line of questioning first. Not only did Nikola not hear (or ignore) the request at the time, but on page 148 where Parry's first question should have appeared he does not even transcribe it, marking it with an ellipsis instead.

27 "M. P." is more common in Pričanja I-III, while "P. P." is more frequent in Pričanja IV-VI (with an occasional "M. P." occurring); in Pjevanje i pričanje both are used. 
attempts of sorts at reinscribing himself as a full-fledged participant in the proceedings and an official authorizer of the transcripts. Whether these are the transcripts of the song recordings or interviews with Salih or with other singers, Nikola often signs them with his full name: "Nikola Vujnović/Vujnović Nikola" (PN 655, III:86, 96, 125; PN 658, V:90), sometimes even including his patronymic "Ivanov" (see the last pages of PN 12434 or PN 275a; PN 12423 and PN 12380 feature the middle initial "I"). In addition to these long signatures - neatly executed, with each letter clearly legible - we also encounter florid abbreviated autographs that seem to communicate confidence (e. g., the last pages of PN 277, PN 12465, and PN 12471), as well as (more rarely) those written hurriedly and absent-mindedly (as in PN 652, I:61, 98). While this medley of signatures seems to point to a person who takes joy in his own handwriting and in seeing his name signed as a confirmation and assertion of his authority, it also perhaps communicates a certain indecisiveness about his identity in relation to the situation at hand, as well as a need to explore and experiment with it.

It is noteworthy that, in his translations of various parts of the Pričanja in SCHS I, Lord seems uncomfortable with the asymmetry of Nikola's abbreviation choices, and thus he opts for marking Parry's speech with a single initial as well, specifically that of his surname. Even so, the encoded hierarchy is still perpetuated, and the habit of thinking of the two natives with reference to their first names and of the collector with reference to his surname is reinforced. The pull of this convention is so strong that, even in this current essay that reflects upon the inequalities of the relationships between the three people involved, I find I cannot refer to them differently myself. At least I cannot do so without perpetrating yet another form of epistemic violence, one that claims to restore justice to the injured parties and thus presupposes the universality of such justice. However, this belief in one's privileged, unmediated access to justice and the right to bestow it would itself, in a twist of deep irony, injure what it presumes to protect.

The stratification inherent in the forms of address, as well as in this transcultural encounter on the whole, seems both unavoidable and unjust, but perhaps there is some justice in that it works both ways - for and against the one on top. As the transcripts and recordings are inevitably narrativized and thus become not only interviews but simultaneously stories about the interviews, the "boss" ultimately becomes isolated and remains (unfairly) at the outskirts of the reader's/listener's sympathies which are (equally unfairly) drawn towards those who become heroes of the story. Furthermore, Salih and Nikola become heroes not only because their voices dominate the recordings, but also because they earn (and impose) narrative intimacy through being called (and calling themselves) by their first names.

\section{Nikola and Salih versus Parry}

As Salih's compatriot, a fellow singer, a member of the working class, and one deeply immersed in the same patriarchal culture, Nikola is the singer's equal-or perhaps is even subordinate to him, if we take their age differences into account. This near equality is reflected in the great variety of forms that are open to Nikola, in contrast to Parry, in addressing the singer. He calls Salih by different nicknames (Salko, Salja, Saliha, and even Salihaga), and he uses patriarchal terms of deference and endearment such as đedo/dedo ("grandpa"), placing himself in the position of instant familiarity, as a curious, loving grandson hungry for his grandfather's 
stories (PN 654, II:93, R 936): Hajde moj dedo! To ti dobro znaš ("Come on, my grandpa! You know that well"). This potential for great rapport that is, time and again, exceptionally well evidenced during the interviews is something that Parry very much counted on when he employed Nikola in the first place. His experience with other interpreters, such as the Russian émigré Ilija Kutuzov, had not been as rewarding. While granting that Kutuzov's knowledge of English (Nikola only spoke Serbo-Croatian) was very useful to Parry during his stay in Dubrovnik in 1933, Lord (1954:7) writes that "as an educated man and a member of the intelligentsia he lacked the understanding and the insight of the peasant singer Nikola."

The following is one of many examples where the warm "grandson-grandfather" interlude precedes a storytelling (PN 656, IV:40, R 983: 3:53-4:04):

\author{
$\mathrm{N}$ : Koju ćemo dedo? \\ S: Ej koju? Pa ćes se nasmijati. \\ N: Dobro! Neka bude malo smiješna. \\ S: Valahi smiješna će bit, i ono je istinito. \\ $\mathrm{N}$ : Which one [story] shall we [pick? hear?], grandpa? \\ S: Eh which? Then you're going to laugh. \\ $\mathrm{N}$ : Good! Let it be a bit funny. \\ S: Well, funny it'll be, but true as well.
}

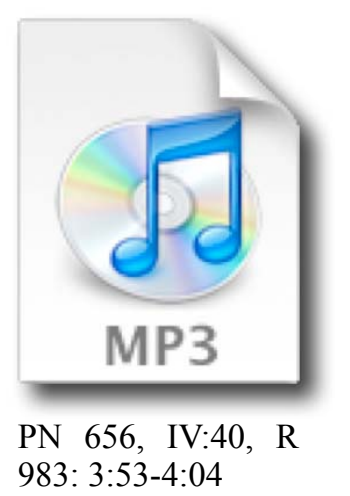

An important thing to notice here is that, even though the collector "boss" is present throughout, the singer excludes him from this exchange. He addresses only Nikola ("you're going to laugh" is rendered in the second person singular); the story is for the "grandson" alone. Although it is impossible to determine whether Nikola's "we" in the above dialogue includes Parry or not, other instances amply exemplify the way he also leaves out the collector while creating this exclusive familial bubble around Salih and himself in order to facilitate a good storytelling situation (for example, PN 656, IV:7-8, R 975: 2:29, 3:13-3:26: A reko si mi . . . ["And you told me ..."], Znašli ti jednu Arnautsku priču . . da mi je pričaš? ["Do you know an Albanian story . . . to tell me?"], E hajde da mi činiš . . . [“"Eh, come on, treat me ...”]). Parry's exclusion is, however, most spectacularly felt when, in rare moments of direct address, his fledgling attempt becomes hijacked by the interpreter - unintentionally and by force of habit and inertia, but with the result of ousting the collector. Thus, for example, when the singer mentions he knows a story about Marko Kraljević and Musa the Highwayman, Parry prods the singer (PN 562, I:50, R 872: 1:18-1:20): E pričaj nam (“Eh, tell us"), upon which Nikola repeats the collector's request while at the same time changing Parry's first person plural (nam) into the first person singular (mi): Pričaj mi to, kako je bilo? (“Tell me that, how did it happen?"). In this way, the initial desire for self-effacement by the scholar backfires in that it is picked up by the singer and the interpreter, who then proceed to efface the collector themselves. The price of that good rapport, likely to produce the most "natural" performance (under the otherwise "unnatural" conditions of a private recording session), is the exclusion of the scholar-foreigner, even as the nature of the conversations and his role in regulating them naturally keep drawing him in. The more forcefully he inserts himself into the conversation, the more he remains on the outside. 
For instance, when the aforementioned story of Marko and Musa finishes, Parry notices that Nikola made a mistake when he inquired from whom the singer heard it. Instead of referring to it as the story of Musa and Marko, Nikola designates it as being o Đerđeljezu $i$ o Marku ("about Đerđeljez and about Marko"). Salih proceeds to answer regardless, knowing what Nikola meant to say: Ovo sam ćuo od jednoga . . . iz Mitrovice Sadika, i on je Bosanac ("I heard this from one [man] . . . from Mitrovica, Sadik, and he is a Bosnian"). However, the collector cannot place his faith in the two singers' contextual understanding and overcoming of the lapse. He cannot rely on the correctness of the received answer, even as his own questions aimed at clarification are themselves insecure, elliptic, and thus in need of contextual understanding by the other two men in whose "club" he does not belong (PN 652, I:67, R 877: 0:13-0:24):

MP: Jeli prićao [Sadik?] o Musi i Marku?

$\mathrm{S}$ [in affirmation]: $E$.

MP: Đe si čuo?

$\mathrm{S}$ [realizing he needs to be clearer but still trying to rely on the context]:

Musu i Marka od onoga sam ćuo.

$\mathrm{N}$ [trying to help out]: U Mitrovici.

S [realizing he needs to complete the "citation" for Parry's benefit]: $U$ Mitrovicu od Sadika Bošnjaka.

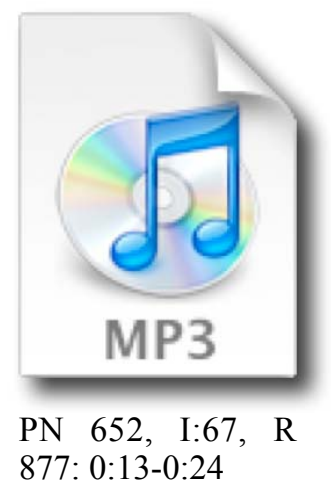

MP: Did he [Sadik?] tell about Musa and Marko?

$\mathrm{S}$ [in affirmation]: Aye.

MP: Where did you hear [it from]?

$\mathrm{S}$ [realizing he needs to be clearer but still trying to rely on the context]: Musa and Marko I heard from that one.

$\mathrm{N}$ [trying to help out]: In Mitrovica.

S [realizing he needs to complete the "citation" for Parry's benefit]: In Mitrovica from Sadik Bošnjak.

This interruption aimed at clarification places the collector further on the outside of the singerinterpreter rapport.

The rupture in the established hierarchy, the way the rug is being pulled from under the "boss's" feet, is perhaps most keenly felt on the rare occasions when Parry attempts to interrogate the singer himself. One such opportunity presented itself during the penultimate interview when Nikola went to the local official to pick up an exemption for Salih from the singing ban that was in place for the duration of the mourning period following the assassination of the Yugoslavian king Aleksandar I Karađorđević in Marseille in October 1934. Whether to save time or to try himself out in the role of the lead interviewer, Parry resumes the recording in the interpreter's absence, making this the longest direct exchange between the singer and the collector. His attempts to imitate Nikola's manner of address are detected by the singer, who occasionally finds the collector's requests funny and perhaps a bit desperate as they are delivered in a commanding tone of voice but with a foreign accent and a lack of Nikola's humorous tone (PN 659, VI:58-59, 70, R 1056, 1061): Da kazivaš dobro ("You are to recite well"); Dobro, ali 
glasnije $i$ dobro ("All right, but [recite] louder and well"); Ali sad misli dobro ("But now think carefully"). Although for the majority of the exchange Salih is likewise trying to conduct business as usual, Parry's Nikola-like imperatives are sometimes met with the singer's barely distinguishable sounds of ironic dismissal and even slight sniggering. To make matters worse, in his imitation of Nikola's argumentative manner ${ }^{28}$ Parry becomes carried away and keeps insisting, erroneously, that Salih continue the song that he had actually already finished reciting just before the respite. Moreover, for all the feigned confidence, Parry stammers a little, repeats himself, and becomes confused about whether the singer should proceed in Albanian or in Bosnian. What this episode starkly reveals is that, while Parry may be the boss, it is Nikola who holds the authority and the singer's confidence. Thus, as mentioned earlier, stratification ends up working both ways: the "boss's" possession of ultimate power is precisely what disempowers him in the attempt to have a closer contact with the singer, and while he may occupy the peak of social hierarchy, he finds that, in society as in nature, peaks tend to be lonely, isolated places.

\section{Nikola versus Salih}

For all the familial intimacy that develops between Salih and Nikola, there still exist between them underlying inequalities and tensions that both men suppress in the congenial spirit of performance. Nevertheless, these tensions and inequalities all surface during the interviews, often only to be laughed off when things become a tad too strenuous. Even at the warmest points of contact, as exemplified in the "grandson-grandfather" exchange above, it is striking how, while playing along, Salih is more reserved, especially during the first three interviews. He accepts but does not directly reciprocate Nikola's solicitations of patriarchal familiarity. Thus, when the interviewer addresses him as dedo/dedo ("grandpa"), Salih does not in turn call him sine/sinko ("son"29), or even sinovac 30 ("nephew"). The singer clearly understands that Nikola is more than what his form of address implied. Rather than just a fellow singer or a frequenter of the coffee-houses in which Salih used to perform, or even a traveler spending the night in an inn and in need of a good story, the wide-eyed "listener-grandson" Nikola is also the extension of the "boss," and thus the honor and familiarity that come from him are not simply a matter of course but are bestowed upon Salih from a higher social perch. As time goes by and the singer becomes accustomed to this particular setup and the two young men, he will on a few occasions relax into his role of "grandfather," take advantage of the situation, and even expect to be treated accordingly. Thus, for instance, in Pričanje IV (83, R 996) he asks Nikola to pass him his cigar; he calls for a break and cigar in Pričanje V (54, R 1015); and he asks Nikola to order his tea in

28 Interestingly, Nikola ascribes Parry's speech here to himself, mistakenly marking it with an "N" rather than "P. P." (PN 659, VI:59).

29 In direct address the corresponding term here would not be "grandson" (unuk) but "son" (sin; vocative: sine). Sine or sinko (diminutive, voc.) are more general forms of addressing younger members of a patriarchal community (even girls!), whether they are genetic or artificial kin.

${ }^{30}$ Note that this noun also has "son" as its root, and it indicates a particular kind of relationship, one that is in patriarchal society second in closeness only to one's own son. As opposed to sestrić (a sister's son) sinovac indicates a brother's son. From this perspective, it is all the more surprising that true heirs of heroes in Serbian epics turn out not to be their sons, nor sinovci, but sestrici $i$. 
Pričanje VI (57, R 1055: 2:28-3:26). However, these grandfatherly biddings are not unequivocally encouraged; instead of a good, obedient grandson, Nikola regularly chooses to play a rascally one (PN 659, VI:57, R 1055: 2:28-3:26):

N: Dobro. Ti malo počini i odmori se [i smisli se $\left.{ }^{31}\right]$ malo, koju pjesmu.

$\mathrm{S}$ [interrupting the end of Nikola's sentence]: Prati mi jedan ćaj tako ti sveca.

$\mathrm{N}$ [most likely pretending not to hear]: Što, što?

S: Jedan ćaj mi prati otud.

$\mathrm{N}$ [now definitely pretending]: Reci dobro, ja te nečujem.

$\mathrm{S}$ [louder]: Jedan ćaj mi prati.

$\mathrm{N}$ [playing silly, yet serious]: Zašto?

S: Da pijem brate.

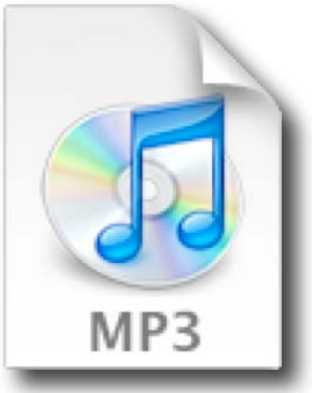

PN 659, VI:57, R 1055: $2: 28-3: 26$

N: Hotli popit rakiju?

S [resolutely]: Jok vala, fala, rakiju neću nikako.

$\mathrm{N}$ [playing ignorant]: Zašto ne?

S: Ja ne pijem nikad.

$\mathrm{N}$ : A Da ti uspe[m?] malo rakije u čaj, bili ti popijo? Zdravije ti je.

$\mathrm{S}$ [adamantly]: Bogami jok, nikako.

$\mathrm{N}$ : Zašto bolan nebijo?

S: Ja sam ostavijo rakiju sad.

$\mathrm{N}$ : E, dobro, ti počini malo sad.

S: A hoću da mislim sad, a ti ... [Nikola here turns away from the microphone addressing someone else (Parry?). The singer now refers to whatever is happening (Nikola lighting a cigarette, or fire in the room?)]: Ne, ne to ti je pala žiška kad si naložijo . . . [Now returning to his earlier request]: Prati mi jedan ćaj.

$\mathrm{N}$ : All right. You rest a while and think a little, which song [you would like to sing].

$\mathrm{S}$ [interrupting the end of Nikola's sentence]: Send me one tea, by your saint. ${ }^{32}$

$\mathrm{N}$ [most likely pretending not to hear]: What, what?

S: One tea, send it for me from there [the coffee-house kitchen?].

$\mathrm{N}$ [now definitely pretending]: Say it well; I can't hear you.

$\mathrm{S}$ [louder]: Send me one tea.

$\mathrm{N}$ [playing silly, yet serious]: Why?

S: To drink, of course.

N: How about some brandy? ${ }^{33}$

${ }^{31}$ This phrase can be heard, but Nikola omits it from the transcript.

32 This trivial request may hardly seem to warrant such a strong oath, but "by your saint" is in fact an automatically employed phrase, a byword used to place light emphasis on supplication. This is also the case with "by God," a phrase frequently employed by both Salih and Nikola.

${ }^{33}$ Nikola is here hinting at Salih's earlier admission that, even though a devout Muslim, he had tasted brandy once and that it had recuperative power on that occasion. 
S [resolutely]: No thanks, I don't want any brandy.

$\mathrm{N}$ [playing ignorant]: Why not?

S: I never drink.

$\mathrm{N}$ : And if they [I?] pour a bit of brandy in your tea, would you drink it? It's healthier for you.

$\mathrm{S}$ [adamantly]: By God, no, no way.

$\mathrm{N}$ : Why, might you not be ill? ${ }^{34}$

$\mathrm{S}$ : I have given up brandy now.

$\mathrm{N}$ : Eh, all right, now you rest a while.

S: And I will think now [about which song to sing next], and you . . . [Nikola here turns away from the microphone addressing someone else (Parry?). Then the singer refers to whatever is happening (Nikola lighting a cigarette, or the fire in the room?)]: No, no, but a spark fell when you lit up ... [Now returning to his earlier request]: Send me one tea.

Although rascally grandsons are usually liked and their antics encouraged in the Balkans, Nikola's reluctance to comply immediately with Salih's requests nevertheless adds weight to the already ambiguous position between the "grandson" and the "boss." This ambiguity makes it hard for the singer to take Nikola's teasing here as simply teasing and not also as indicative of a change from the role of grandson into that of the "sub-boss" who should not be expected to serve his employees, at least not without giving them a bit of a hard time in the process. Moreover, the patriarchal culture itself, the culture that sets such great store in honoring its elders is very much the culture that above all favors males of the fighting age, men at the peak of their physical and mental powers - in other words, men like Nikola and Parry. This means that the darker side of honoring elders is patronizing and infantilizing treatment. In particular, the usual respect and care for the elderly can sometimes give way to annoyance with their physical and/or mental infirmities. For instance, the frequent need to remind the singer to speak more loudly proves frustrating for all and sometimes induces Nikola to address the singer coolly, as stari ("old man"), instead of with his usual warm dedo/dedo ("grandpa") (e. g., PN 655, III:78, R 957).

And yet these are among the least noticeable tensions between the two men. Their ethnic and religious differences produce uneasiness of a much more conspicuous nature. ${ }^{35}$ Nikola and Salih may both be Yugoslavs, and they may be speaking the same language in these interviews,

${ }^{34}$ As in the previous note, bolan ne bio (literally: "might you not be ill," meaning something along the lines of: "God save you from being ill") is just a characteristic expression in Bosnia and Herzegovina and is used here for light emphasis.

35 These religious tensions are also present in the exchange quoted above, as when the Christian Nikola (even if jokingly) repeatedly offers the Muslim Salih some brandy, knowing that his religion forbids it. However, in Nikola's defense it should be said that the ban on alcohol was (and very likely still is) among the least observed religious prohibitions among the Balkan Muslims. 
but in order to understand each other, Salih has to speak in Serbian/Bosnian, ${ }^{36}$ the language ${ }^{37}$ of the Slavic majorities, and not in his mother tongue. Most likely, this was not very difficult for the singer since the songs that were most pleasing to him to hear and sing were in that language, even if he did occasionally struggle to explain to Nikola the meaning of some of the Turkish and Albanian words that appear in his Bosnian epics. However, regardless of the levels of difficulty involved, it is Salih who must make the additional step towards his interviewer rather than the other way around.

While Salih is an old Albanian Muslim, Nikola is a young Catholic from Stolac in Herzegovina, most likely Croatian on his father's side and Serbian on the side of his mother. ${ }^{38}$ With one man singing praises to Muslim heroes and the other to Christian ones, the radical difference in their political and religious sympathies was understood, even if it was only seldom allowed to surface, mostly in the guise of jokes. Only decades prior to their meeting (and during Salih's own lifetime) Christians had freed themselves from centuries of Ottoman rule, with the fiercest Muslim resistance coming precisely from areas such as Sandžak in which the town of Novi Pazar lies, and where Parry and Nikola met Salih. In every major and minor conflict mentioned during the interviews, the old singer fought against Christians-whether Serbs, Montenegrins, or Greeks. Although pleasant and congenial, the situation was also charged with these tensions. On the few occasions in which Nikola addresses Salih as "Salihaga"-which is a

${ }^{36}$ Salih refers to the language as both Bosnian (more often, since the songs he sings come from Bosnia) and Serbian. Interestingly, his much younger fellow singer who is also an Albanian, Alija Fjuljanin, refers to the language as "Yugoslavian" (PN 666:17, R 1146), and, unlike for Salih who apparently only learned it as a 30-yearold adult (PN 652, I:8, R 860), for Alija it is the language of everyday life. Other young singers from the same area, such as Suljo Fortić, also exhibit a more Yugoslavian spirit (PN 277b:32, R 127). Lord sees this as an effect of the "nationalist propaganda" of the time (SCHS I:400), but note that the "nation" of choice here is one that attempts to include the various ethnically and religiously divided citizens of Yugoslavia, and give them a sense of common belonging. In those times, as well as in more recent times, such endeavors proved controversial since inclusion on one level (global) often comes at the cost of suppression at another (local), and inclusiveness, although usually viewed as something a priori positive, can also have affinities with colonialism.

37 Bosnian, Croatian, and Serbian are now considered separate languages. However, some treat this as primarily a political rather than linguistically justified division, which seems to be reiterated by the current tendency among Slavists to refer to the three as a single entity with strategically inserted slashes (or dashes) and a common acronym: "Bosnian/Croatian/Serbian (BCS)." See, for example, Alexander and Elias-Bursać 2006.

38 Nikola is invariably simply referred to as a Herzegovinian Catholic (for example, Kay 1995:32). However, a more complex picture of his identity emerges when one pieces together some otherwise unrelated notes from Mathew W. Kay's Index (1995). Here, two singers of different faiths from Nikola's village of Burmazi are both listed as his uncles - the Catholic Vlaho Vujnović (Kay 1995:32, 135) and the Orthodox Đuro Kučinar (Kay 1995: 101, 135). Judging from the surnames, Kučinar must have been a maternal uncle, which very likely means that Nikola was a product of a mixed marriage between a Croat father and a Serbian mother. Nonetheless, one is in dangerous waters when conflating ethnic and religious identities, and we must allow for there being Catholic Serbs and perhaps Orthodox Croats as well. Whatever the case, Nikola's origins and outlook will have been complex, and an Orthodox mother and uncle might perhaps shed some light on Nikola's unusual persistence and zest in asking Salih to sing a "Serbian" (PN 652, I:34, R 867), or an "Orthodox" (PN 655, III:49-50, R 949) song. Note in particular that Nikola could have well asked for a "Christian" song, but he never does, and instead he keeps specifying the desired song as either Orthodox or Serbian. These parts of the Pričanja are discussed in greater detail below. 
gesture of exaggerated respect ${ }^{39}$ that poor men are known to extend to one another half-jokingly and half in acknowledgement of their inner nobility and mutual agha-like generosity of spiritthe unintended but nonetheless biting irony is that Salih really had been an agha ${ }^{40}$ in what he considered the "good old days" of Ottoman governance, ${ }^{41}$ when people like Salih ruled people like Nikola and before poverty struck the former lords. Now that the tables have turned, Nikola's inadvertent invocation of Salih's former title is mildly unsettling, especially when measured against the instances when his joking remarks are indeed tinged with sarcasm and provocation. For example, when he asks the singer whether the Muslim lords fleeing from Bosnia used cars or were travelling on foot (PN 674, VII:2, R 1229), or whether the three men Salih said he beheaded in the various skirmishes with Montenegrins and Greeks were tied, he "concludes," after denials from the singer (PN 652, I:20, R 863: 2:39-2:50), sigurno su neka deca bila ("those must have been some children"). As these were all jokes, they were invariably met with the singer's laughter, but they were also immediately followed by his negation and desire to ensure that the records were set straight.

Salih and Nikola are both singers of South Slavic oral epics, and they share the same inherited idiom and gallery of warriors, yet their songs spring from two distinct branches of that common tradition, the most conspicuous difference being that the heroes and adversaries of one branch exchange places in the other. The two men may both be said to belong to the peasant/ working classes, but Nikola is literate, and although he has but four years of schooling, this already situates him four social degrees above Salih in terms of opportunities. After all, it is those years of meager education that placed him in Parry's employ; his status in respect to the singer grows by this association. He is the "boss's" extension, his spokesman, his negotiator, and the one in charge of leading the interviews and managing the purse. Nikola can therefore wield these powers over the singer as he pleases (PN 659, VI:12, R 1044: 1:52-2:27):

title.

${ }^{39}$ Aga ("agha") is a title of a minor Ottoman official, here a landowner, although "agha" was also a military

40 See, for example: PN 652, I:13, R 861 or PN 656, IV:76, R 994.

${ }^{41}$ For example (PN 656, IV:17-18, R 978): N: Jeli tebi žao stari, što se tako okrenulo? S: Dosta vala. N: Žao ti je veliš? S: Vala dosta! N: Bili volio da je danas turčin ovđe? S: Vala ja turčina jok, tek muslimana. Turčin ima $i$ ciganin [the singer laughs here]. (N: "Do you regret, old man, that things turned around like this? S: Very much, indeed. N: You regret it, you say? S: Indeed, very much! N: Would you prefer that the Turk be here today? S: Well, I wouldn't [want] the Turk [necessarily], but a Muslim. There are Turks who are Gypsies even [the singer here laughs].") It should also be added that in general Salih laments the passing of what for him was the "heroic age" (e.g., PN 655, III:62-63, R 952). 
N: E hajde sad lijepo ${ }^{42}$ Salja, od kraja do konca, ali, ako puštiš koji stih, nećemo ti platit ništa.

$\mathrm{S}$ [anxiously]: A da nemogu dok se neodmorim, bogme, ono [the song] je dugaćko. Teke po jedan mah da stanem da se odmorim.

$\mathrm{N}$ : Dobro, dobro, kada budeš umorit se, a ti odmori ${ }^{43}$

$\mathrm{S}$ [interrupting the end of Nikola's sentence above]: A onako da brojim hoću.

$\mathrm{N}$ [feigning seriousness in a "schoolteacher" manner]: Jes, jes, jes, ${ }^{44}$ samo svako slovo ako nebudeš kazat, tačno, ja je znam cijelu....

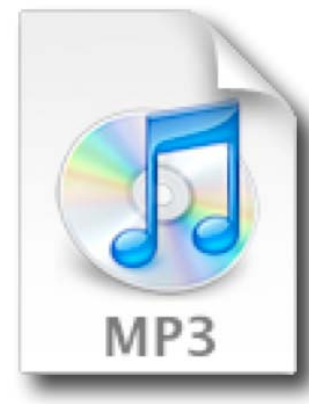

PN 659, VI:12, R 1044: $1: 52-2: 27$

S [interrupts again]: Ja vala. . . .

$\mathrm{N}$ : Ako nebudeš kazat tačno [Salih here interjects, defensively: Oooh], nećemo ti platit ništa.

[Exclaiming, as though to cut the interruptions from the singer and stress his seriousness]: Salja! ${ }^{45}$

$\mathrm{S}$ [continues, slightly dejected and defensive at the start, but gaining confidence]: Oh, ja ne znam kako koji peva, a ja kako je pevam, belji ostavit neću. ${ }^{46}$

$\mathrm{N}$ [interrupting the end of Salih's sentence above]: E dobro! E hajde, bicmilah!47

${ }^{42}$ This word can be heard, but it is missing from the transcript.

${ }^{43}$ Nikola's transcript differs slightly from what can be heard (which is what I prioritized here), but the meaning remains the same. Nikola even crosses out the verb odmorit [i] ("to rest"), which he wrote first, and replaces it with umorit [i] ("to get tired"), which in the context makes more sense: "All right, all right, when you get tired, you take a rest." In this particular case I followed the transcription because I cannot tell with certainty what Nikola actually said. It is possible that he said odmorit, just as he first transcribed, either as a slip of the tongue or to mean something along the lines of "when you need a rest, take a rest." Evidently, the great similarity of the two words makes the slip of the tongue (and ear!) an easy occurrence.

${ }^{44}$ This last jes is not transcribed.

${ }^{45}$ This word of address can be heard, but it is missing from the transcript.

46 The word neću ("won't") is included in the transcript, but it is inaudible to me, as Nikola interrupts the singer at this point. It seems to me more likely that Nikola added this word for clarification, but it is also slightly possible that he recalled hearing it amidst his interruption.

47 The word bicmilah means "in the name of god/Allah" (cf. Škaljić 1966:145), and while it is featured in many opening chapters of the Qur'an, "Muslims often say this phrase when embarking on any significant endeavor" (http://wahiduddin.net/words/bismillah.htm). Interestingly, when Nikola transcribes this word he departs from his pronunciation (bicmila), correcting the initially written "c" (pronounced "tz") into "s" and adding an "h" at the end so that it reads: bismilah. It is interesting that, with the exception of a couple of diacritics, this form is the same as it later appeared in Škaljić's 1966 dictionary of turcizmi (Turkish-derived/-adopted words) in SerboCroatian (145). Whether Nikola used a reference book of a similar kind or someone (perhaps Parry?) advised him to do so, I cannot offer a cogent explanation as to why he decided here to write the word differently from the way in which he pronounced it. This is particularly out of character since Serbo-Croatian is a phonetic language and Nikola followed this principle throughout the transcripts, including when he rendered the regional and personal peculiarities of his own and Salih's speeches. The puzzle only becomes more difficult to solve when one considers the matters discussed in the footnote below. 
$\mathrm{S}$ [with a small laugh of approval, amused by Nikola's "Islamic" exclamation]: Bicmilja ${ }^{48}$ i Bože pomozi.

N [instructively]: Samo čisto, jasno, glasno da pjevaš.

$\mathrm{S}$ [calmed, in affirmation]: $A d a$.

$\mathrm{N}$ : Eh, come on now, Salja, nicely, from the beginning to the end, but if you miss a verse, we $\mathrm{e}^{49}$ are not going to pay you anything.

S [anxiously]: Eh, I can't until I rest first, by God, it [the song] is too long. But if I stop at one point to rest a little. ${ }^{50}$

$\mathrm{N}$ : Yes, yes, yes, but if you don't say every letter, exactly, [Salih here interjects, defensively: Ooo], I know it [the song] whole....

$\mathrm{S}$ [interrupting the end of Nikola's sentence above]: And I'll recount like that.

$\mathrm{N}$ [feigning seriousness in a "schoolteacher" manner]: All right, all right, when you get tired, you take a rest.

S [interrupts again]: Well, yes....

$\mathrm{N}$ : If you don't say [it] exactly, we are not going to pay you anything. [Exclaiming, as though to cut the interruptions from the singer and stress his seriousness]: Salja!

$\mathrm{S}$ [continues, slightly dejected and defensive at the start, but gaining confidence]: Oh, I don't know how others sing it, but the way I sing it, I [won't $]^{51}$ leave out anything, of course.

$\mathrm{N}$ [interrupting the end of Salih's sentence above]: All right, then! Eh, come on, bismillah!

$\mathrm{S}$ [with a small laugh of approval, amused by Nikola's "Islamic" exclamation]: Bismillah and with God's help.

$\mathrm{N}$ [instructively]: Only sing neatly, clearly, loudly.

$\mathrm{S}$ [calmed, in affirmation]: Well, yes.

48 As far as I can hear, Salih completely follows Nikola's pronunciation here, save for the softer "l" (effectively "lj") peculiar to Albanian pronunciation: bicmilja. However, Nikola opts for transcribing the singer's word as basmalja. Why Nikola does this is a mystery. However, as it happens, basmalja is uncannily reminiscent of the Arabic word basmala, which is cognate to bismillah and basically has the same meaning (see http:// en.wikipedia.org/wiki/Basmala). I am completely baffled as to whether these changes are a sheer coincidence or if Nikola was somehow aware of the history of these various words (perhaps through the cultural affinity with the Bosnian Islamic milieu) and used the cognate versions to better distinguish his speech from the singer's.

49 Note how, when payment becomes the topic of his sentence, Nikola reverts to the first person plural instead of his usual intimate first person singular. As the money is the ultimate prerogative of the "boss," Nikola's authority in this area needs buttressing and he thus invokes Parry.

${ }^{50}$ In my opinion, Lord slightly mistranslates this sentence and as a result, the following few lines of this part of Pričanje VI as well, which he includes among the notes accompanying Salih's song "The Captivity of Đulić Ibrahim." The crucial misunderstanding occurs when he takes the singer's words da stanem to mean "to get up" instead of simply "to stop." If the singer had wanted to convey what Lord thought, he would have most likely said da ustanem. The root of the two verbs is the same, which perhaps explains the misunderstanding. Lord's translation of this part of the interview is thus slightly confusing and reads as follows (SCHS I:350): "S: [ . . ] Let me get up for just a minute and rest a little. $N$ : All right. Since you're tired, take a rest. $-S$ : Well, I'll recite it now. $N$ : But every word. If you don't recite it exactly — I know the whole of it! ... If you don't recite it exactly, we shall not pay you a penny. $S$ : I don't know how anyone else sings it, but I won't leave a thing out from the way I sing it. $N$ : All right, go ahead!"

${ }^{51}$ Added by Nikola, either automatically, or for clarification. 
And so in one fell swoop Nikola ends up thrusting his "grandfather" Salih, the wise elder, into the shoes of an inept schoolboy. Of course, Nikola does not really mean what he says here, and from his manner the singer can also tell that he probably does not mean it. However, "probably" is the crucial word here, since in that small space of real doubt lies the success of Nikola's teasing, his interviewing skill, and his power of authority over the singer (since, theoretically, he can decide at any time to stop joking and make the threat real). Thus the singer is on the edge until the end of the exchange: he laughs, but he also objects, becomes alarmed, and is forced to stall and justify himself in advance of the performance. Although Nikola puts the payment at the center of his "threat," everyone involved seems aware that this is not what is ultimately at stake. Salih's responses all focus on his singing and not once does he raise the issue of money. Even if five to six banki $^{52}$ per day was not insubstantial ${ }^{53}$ for someone who made his living by doing odd jobs - from giving people advice on purchasing cattle ${ }^{54}$ to mending broken bones ${ }^{55}$-it seems clear that Nikola's "threat" to withhold payment was primarily hurtful to his artistic pride and potentially his reputation, rather than to his purse. More likely, the payment is invoked to give a bit of weight to Nikola's purposefully "literate" references and purported assumptions about completeness, exactitude, and the fixity of a narrative (note the exaggerated emphasis on "every verse" and "every letter"), as well as the notion of a correct/authorized version ("I know it whole"). He says these things not because he really considers such post-print attitudes toward texts to have value in the oral context; after all, he is a singer himself. On the contrary, as in reverse psychology, they are spoken to provoke Salih to react in opposition and thus reveal "oral" attitudes towards the stability (or the lack thereof) of an epic song and towards different singers' renderings of the "same" song. Indeed, Salih delivers what the interviewers were hoping

52 In post-WWII Yugoslavia, a banka (or rather a para) was a unit worth a hundredth of one dinar. However, in the Yugoslavia of the 1930s, it seems that a banka was a larger unit, equal to 10 dinars. For instance, in Pričanje III (1-3) both Nikola and the singer refer to the 20 dinars that some man owed Salih as "two banke." Later on, when asking him to compose a song about their encounter, Nikola will mention that they were paying Salih five to six banki per day (PN 655, III:106, R 965). In addition, at the end of Pričanje $V(141-42)$ Nikola and Salih talk about the coin or note that the singer seems to have just received from Parry and call it petica ("a fiver") and pet banki.

53 Thus far I have not been able to find a reliable source of information regarding prices and salaries in the Kingdom of Yugoslavia in the 1930s, but if the casual Google search result is to be taken into consideration, and an average worker's monthly salary was indeed 500-600 dinars, then 5-6 banki (50-60 dinars) a day would be a tenth of a monthly income, which would have been a nice sum. This is especially true when taking into account that Salih, although indicated as a "worker" in one of the transcripts (PN 277:1), was not formally employed anywhere and therefore could not have hoped to earn as much as a factory worker. (See http://www.svastara.com/razno/novcanice/ kj/cene.html.)

54 Salih was a cattle trader while in his prime (see, e. g., PN 654, II:26, R 914). As Alois Schmaus testifies (1938:275), Ovaj njegov stari zanat $i$ danas mu je prirastao za srce. Još uvek voli 'pomalo da džambasa' na novopazarskoj goveđoj pijaci. Tamo sam ga jednog utornika, kad je bio stočni pijac, jedva i pronašao u kasno poslepodne. ("This old trade of his is close to his heart even today. He still likes to 'cattle-trade a little' at the Novi Pazar cattle market. It was there that I only just managed to find him late one Tuesday afternoon when the cattle market was on.")

${ }^{55}$ See, for example, PN 652, I:16, R 862. 
for, but in order to ensure that the information is "genuine" (in other words, that the singer's answer is uncontrived $)^{56}$ he cannot be let in completely on the joke, he cannot be "in the know."

The whole scene could be read in the context of the folktales so familiar to both men: Nikola confronts Salih with an impossible task, but, as he cannot threaten the singer with his life if he fails, Nikola puts his payment on the line instead. However, unlike the familiar folktale scene, this threat is not made so that the hero-singer can in the end achieve the feat against all the odds (that is, sing the most beautiful, complete, and perfect song according to the tastes of the two young men), but in order to force him to divulge unadulterated views on distinctive features of the oral tradition - the real prize all along. And so, while masquerading as the "king" who sets an unattainable goal to the prospective suitors of his daughter, the crafty Nikola in fact himself acts as a folktale hero who, through slyness and wit, makes the "dragon" (or some other adversary) reveal the true source of his power. A direct question would not have accomplished this goal; instead, the dragon would have eaten the hero, with the creative singer likely providing an answer specially tailored to the situation, fishing for whatever he assumed his interviewers were hoping to hear. ${ }^{57}$ Thus, to have Salih in the know is to ruin the experiment, yet not to have him in the know objectifies him: turned into the proper subject of an experiment, he becomes just that-subjected. While chosen to illustrate the fluctuating power relationships and inequalities underlying Nikola's and Salih's interactions, in the same breath the quoted dialogue reveals all the major aspects of epistemic violence perpetrated against the singer by Nikola and Parry acting together as a unit: objectification, teasing tinged with condescension, cognitive pressuring, and imposition/privileging of a kind of logic foreign to the singer (whether real or, as here, purported). ${ }^{58}$

\section{Perpetrating Epistemic Violence: Nikola and Parry versus Salih}

Interesting and instructive as they are, the interviews with Salih form only a part of the whole series of long and short "conversations" with singers throughout the regions of the Kingdom of Yugoslavia in which oral epic singing was still active. And while the singers changed, the collector and the mediator remained the same, building their professional and presumably personal relationship, too, on what seems to have already been a strong foundation. Nikola was not only Parry's assistant but was also the very first singer the collector encountered

\footnotetext{
56 Indeed, in "Ćor Huso" Parry reflects on the dangers of taking the singers' answers at face value since "far transcending any desire to speak the truth is his [the singer's] desire to give the answer which will please the most and will place himself in the most favourable light" (Parry 1971:447). While Parry here talks about singers in general, it is interesting that the two examples he gives to illustrate the point are in fact those of Salih and Nikola.

57 This type of response is one that Salih (and other singers; see the above footnote) made rather often. Note, for example, how during the course of the interviews the singer realizes that what Parry values is not just an epic song, but a long epic song (e. g., PN 658, V:54, R 1015; PN 659, VI:57, R 1053). I return to this issue in the section "Cognitive and Physical Strain."

58 Note how, as he delivers his comical threat, Nikola indicates that he here acts as a part of a duo; he temporarily bursts the bubble of intimacy shared with the singer and emphasizes instead his allegiance to Parry as primary, swapping his first person singulars ("tell $m e$ ") for first person plurals ("we are not going to pay you anything").
} 
upon his arrival to Yugoslavia (cf. Lord 1954:6). That Parry's choice of interpreter/mediator should fall on the first person he heard sing seems in itself to indicate that the two took an instant liking to each other. Already in 1933 Parry praised not only Nikola's "professional knowledge of the poetry" and the region, his honesty, and his negotiating skills - all of which must have qualified him well as a guide - but also his "unusually ready understanding" (6) of what the scholar wanted from the singers. Furthermore, Parry never attempted to change his native assistant, while Nikola was obviously motivated enough to subject himself to training "in the arduous techniques of writing down songs from dictation" (6), as well as to leave his home and way of life for protracted periods of time in order to be included in Parry's expedition. This effort would hardly have been worthwhile if the two men had not had a personal liking for one another and if their rapport had not been good.

Although they came from different cultural backgrounds and walks of life, Nikola and Parry were of similar age and shared a common passion for the epic song. Through this close involvement in a common undertaking, they had time to develop their fellowship. When they met old Salih, they were likely already a team, the enduring allegiance of which overrode any temporary one that Nikola may have formed during the interviews with the singer of the day. They were also two literate young men with "modern" views (for example, through their questions to the singer they both imply that the change of rule that allowed Muslim women to uncover their faces was for the better; PN 674, VII:5, R 1229) and they had a similar sense of humor. (Note how they both encourage Salih and laugh during his account of his own heroics; PN 652, I:20, R 863: 2:48-2:57.) However, what distinguishes the two as a unit overall in respect to the singer is that they shared the aforementioned "unusually ready understanding" that they were the ones in the know. It is this particularly well-functioning aspect of their relationship that also pitted them against the singer and caused the epistemic violence to be administered so efficiently. The collector provided the epistemic framework for the experiments to be conducted with the singer, the mediator the most effective means of enforcing it: the joke.

\section{Joke Power}

Considering that how something is done colors all aspects of what is being done, in this section I will focus on the power of the joke, or rather, on the role of humor as a device that facilitates a relaxed working atmosphere and vital social cohesiveness, but also acts as an instrument of epistemic violence. One would be hard pressed to think of a more ingenious way to enforce something than through joking, as neither party need be fully aware of what is being enforced. The joke blunts the edge of violence, and its spontaneity excludes premeditation, which, if present, would make the interviewer's success seem sinister. At the same time, joking and teasing as a way of obtaining information can be tinged with condescension. And although here the young men's manner towards the singer is generally kind and respectful, and Nikola's humor in the vast majority of cases is well-meant and good-spirited, the accompanying patronizing effect that some of these jokes have itself imparts a distinct kind of violence on the one at the receiving end. In the present case this is all within the permitted cultural boundaries, which, as noted before, to some degree license(d) the child-like treatment of the elderly. To the extent to which I, having been born and brought up in the not-so-different Yugoslavia, can claim 
any sort of inside knowledge, such conduct was most likely never meant to be hurtful or condescending, but in a way affectionate. This intended affection would also partly explain why the elderly members of the patriarchal community endure(d) it, the other possible reasons being their dependency upon the young's provision of care and the knowledge that they were once young (and acted similarly) themselves. However, this does not mean that they also enjoyed it, even if we allow for each individual to have different levels of tolerance and a penchant for selfirony. Indeed, from the ample praise that Parry and Nikola bestow upon the singer following a satisfying narration (PN 652, I:67, R 876): N: Eh Bogami dobro. Dobro si to pričao! MP: Dobro! (N: "Eh, by God, that was good. You told that well!" MP: "Good!") to gentle chiding (PN 659, VI:43-44, R 1052): N: E vidiš koliko ti meni tako preskočiš, izostaviš stihova (N: "Eh, you see how much you skip over on me like that, [how you] leave out verses!") and joking threats (PN 659, VI:12, R 1044): N: . . a ali, ako puštiš koji stih, nećemo ti platit ništa (N: “. . . but if you miss a verse, we are not going to pay you anything!"), all the way to biting rebukes in order to motivate him to "do better next time" (PN 674, VII:18, R 1233): MP: Sigurno da bi dobar pjevać ... (MP: "Surely, a good singer would ..."), old Salih is often treated as a youngster, a pupil who is awarded or reprimanded according to how well or badly he performs for his "teachers."

In particular, the characterizing feature of Nikola's approach to Salih is similar to that found in the games of knowledge that adults often play with children. For example, instead of asking the singer a direct question, Nikola, by way of testing to what extent Salih is really familiar with the epic landscape of his songs, often pretends not to know where this or that town is, or makes a purposeful mistake, so as to give the singer the opportunity to "correct" him (PN 654, II:43, R 921: 0:55-1:03):

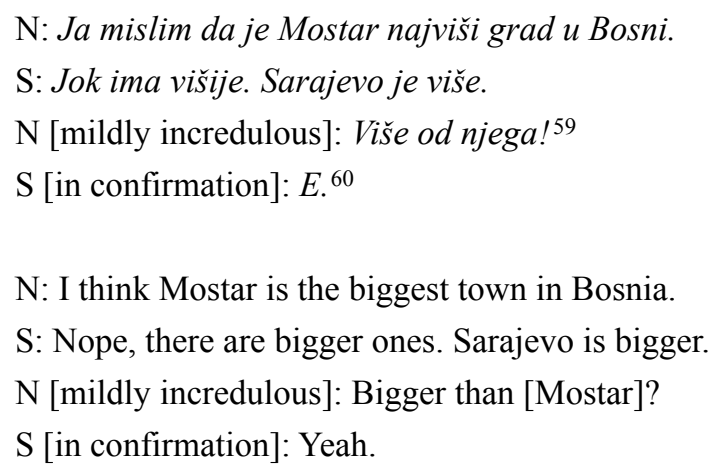

$\mathrm{N}$ : Ja mislim da je Mostar najviši grad u Bosni.

S: Jok ima višije. Sarajevo je višse.

$\mathrm{N}$ [mildly incredulous]: Više od njega! ${ }^{59}$

$\mathrm{S}$ [in confirmation]: $E .^{60}$

$\mathrm{N}$ : I think Mostar is the biggest town in Bosnia.

S: Nope, there are bigger ones. Sarajevo is bigger.

$\mathrm{N}$ [mildly incredulous]: Bigger than [Mostar]?

$\mathrm{S}$ [in confirmation]: Yeah.

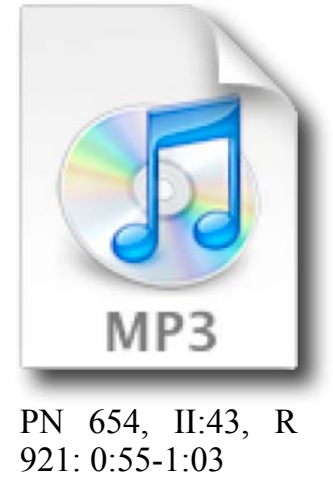

On other occasions Nikola feigns confusion, seemingly needing the singer to help him out, but in fact hoping to perplex him and in turn achieve a comical effect. Thus, for instance, when the singer once refers to ženska pijaca (a "women's market") meaning the green market, which, as opposed to the cattle market, was dominated by female sellers and buyers, Nikola asks excitedly if that is a place where women are sold and if he could go there and buy one for himself (PN 659,

\footnotetext{
${ }^{59}$ Nikola places an exclamation mark here, but his sentence is delivered more as a question, requiring the singer to confirm his claim.

${ }^{60}$ This word is delivered quietly and is not included in the transcript.
} 
VI:3, R 1042). Similarly, when they talk about the Islamic heaven and hell, Nikola uses the alliterative proximity of the two words-dženet (or denet in the singer's softer pronunciation) and džehenem (dehenem) ${ }^{61}$ - to act mixed up and create comic confusion. As the singer finishes describing the heavenly bliss that the deserving may expect to find in $d$ ženet, Nikola interjects as follows (PN 654, II:90, R 935: 2:20-2:25):

$\mathrm{N}: Đ e$ ? U džehenemu, jeli?

$\mathrm{S}$ [pronouncing slowly for emphasis]: $U$ denet!

$\mathrm{N}:{ }^{2}$ A kako je u džehenemu?

$\mathrm{S}:$ A u đehnem ${ }^{63}$ sačuva Bože!

$\mathrm{N}$ : Where [is all that]? In hell, isn't it?

$\mathrm{S}$ [pronouncing slowly for emphasis]: In heaven!

$\mathrm{N}$ : And how is it in hell?

S: But in hell, God keep [us from there]!

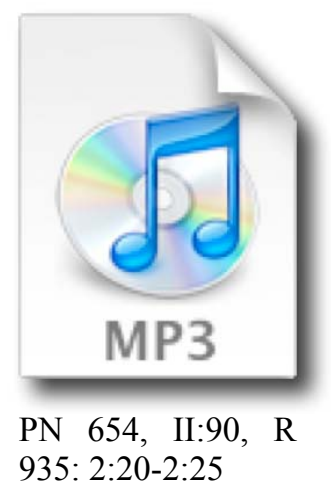

The conversation about what to expect in each place continues for a while, and once again Salih dwells on the lovely things one can experience in heaven, when Parry interjects (PN 654, II: 92-93, R 936: 0:51-1:09):

MP: $E^{64}$ kad ti umriješ?

$\mathrm{S}$ [longingly]: Ej ako bogda tu da me povedu!

$\mathrm{N}: U$ džehenem ${ }^{65}$ jeli? $^{2}$

S [emphatically]: Nedaj Bože [Nikola and Parry chuckle].

$\mathrm{N}$ [through laughter]: Đe bi ti volijo? U dženet ili u džehenem?

$\mathrm{S}$ [laughing along]: Ej, ja bi volijo u đenet ... [makes a hopeful sound and then coughs]: dekiku no ovamo hiljadu godina.

MP: And when you die?

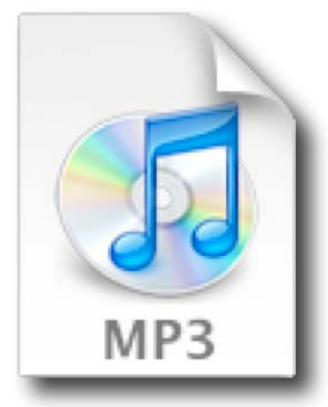

PN 654, II:92-93, R 936: 0:51-1:09

$\mathrm{S}$ [longingly]: Eh, may God grant that they take me there!

$\mathrm{N}$ : To hell, you mean?

S [emphatically]: God forbid [Nikola and Parry chuckle].

$\mathrm{N}$ [through laughter]: Where would you like to go, to heaven or to hell?

61 On some occasions Nikola and Salih use slightly different, abbreviated, but still similarly sounding variants such as džehem, džehnem, and đehnem. See the subsequent quotations.

${ }^{62}$ Nikola mistakenly marks his own speech with an " $S$ " here.

63 In the transcript, Nikola mistakenly replaces this noun with a corresponding pronoun in the locative: njemu.

${ }^{64}$ Here Nikola writes ali ("but") instead.

${ }^{65}$ Although here he actually says $d \check{z}$ ehenem, Nikola writes the shorter version in the transcript: $d \check{z} e h n e m$. 
S [laughing along]: Eh, I would like to [go to] heaven ... [makes a hopeful sound and then coughs]: [and spend] a minute [there] rather than [be] here for a thousand years.

For all the "clarification" and Islamic instruction Nikola receives, he will, after a while, make the same "mistake" one more time before finally giving up and causing another bout of laughter in the process (PN 654, II:96, R 937: 2:25-2:45):

\section{$\mathrm{N}$ : I onda kad se umre, onda se ide u džehenem ${ }^{66}$ jeli?}

S: Ne, ${ }^{67}$ neko u đenem, ${ }^{68}$ neko u đenet. Tu nema sem $^{69}$ dva, dva puta.

$\mathrm{N}$ : Dva puta?

S: Nejma! Tré́e nejma!

$\mathrm{N}$ [laughing while hinting at a known saying]: A sad ako zna ${ }^{70}$ đadu dobro je! [Both chuckle.] A ko nezna đadu, ode u Kaniđu jeli?

$\mathrm{S}$ [laughing in recognition and quoting the full rhyme]: Ooo! $!^{71} A d a !$ "A ko nezna đadu, on ode u Kajniđu gradu."

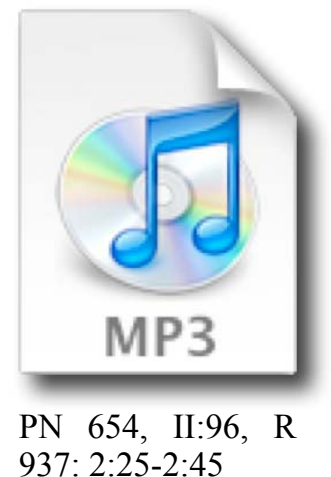

$\mathrm{N}$ : And then when one dies, one goes to hell, doesn't he?

937: 2:25-2:45

S: No, some [go] to hell, some to heaven. There are but two, two ways there.

$\mathrm{N}$ : Two ways?

$\mathrm{S}$ : There isn't. There isn't a third.

$\mathrm{N}$ [laughing while hinting at a known saying]: Well now, whoever knows the road, good [for him]!

[Both chuckle.] And who doesn't know the road, off he goes to Kaniđa!

$\mathrm{S}$ [laughing in recognition and quoting the full rhyme]: Oooh! But of course! "Who doesn't know the road $\left[\right.$ down $\left.^{72}\right]$, he ends up in Kajniđa ${ }^{73}$ town!"

The other side of this game - in which the "adult" pretends to know less than the "child"-is when s/he instead pretends to possess superior, even superhuman knowledge. One such instance we encountered earlier when Nikola claimed in an exaggerated manner to know the "whole

${ }^{66}$ Again, Nikola writes džehem instead.

67 Nikola here writes $E$ instead, but both this sound and what I hear are aimed at communicating the singer's negative answer.

68 This time Nikola does the opposite and writes the longer version: đehenem, even though the singer uses the abbreviated one.

${ }^{69}$ Nikola mistakenly renders these two words (nema sem) as one: nemaše.

${ }^{70}$ For some reason, Nikola renders this verb (here and with the negative form in the next sentence) as the second person singular in the transcript.

${ }^{71}$ Nikola marks the exclamation as $U$ !, but I believe Ooo! is closer to what the singer utters.

${ }^{72}$ I added this word for the rhyme to work.

73 The town in question is in fact Kanjiža in Vojvodina, Serbia. Located at the county's northern border (with Hungary), it became the proverbial faraway (yet-still-reachable, real) place for people from the southern and central regions of Yugoslavia. The town features prominently in the geography of the epic tradition. 
song" that Salih was asked to sing, therefore being able to detect instantly if the singer missed so much as a letter. On another occasion, Salih tries to free himself from a sticky situation by claiming that the (possibly fictitious) manuscript he mentioned in Pričanje $V$ would be of no use to Nikola since he does not know either Turkish or Arabic. The interpreter then insists that he knows both languages well, concluding with the following boast (PN 659, VI:5, R 1043): Znao je Mujov Halil dvades $i$ ćetiri, ja znadem dvades i pet jezika ("Mujo's Hali174 knew 24; I know 25 languages").

However, the most interesting example of this kind is surely when, following Salih's long and passionate description of the past heroic age filled with cries of wounded warriors, Nikola asks whether, in any of the actual skirmishes in which he fought, Salih personally had an occasion to cry out to his mother (PN 655, III:63-64, R 953: 0:17-0:35):

S [recites]: Neko viće jao mene majko, Neko kuku prifatime druže!

$\mathrm{N}$ [through laughter]: Jesili ti koji put reko: "Kuku majko!"

S [emphatically]: Nikad! [Through laughter, but adamant]: Nijesam zakukao tako mi vere!

$\mathrm{N}$ : A kako, kad je jedan stari mene iz Hercegovine meni pričo, da te ćerao kad si ratovao tamo neđe s Crnogorcima? Da te pušijo preko nekoga polja.

S [through laughter, but firmly denying]: Au, tako mi Boga laže! [Someone interjects with laughter, most likely Parry.] Auh, nije tako mi Boga ni video....

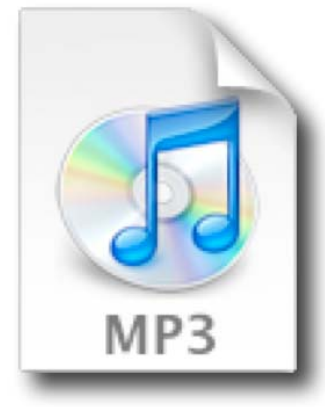

PN 655, III:63-64, R 953: 0:17-0:35

S [recites]: Someone cries: "Woe to me, my mother," / Someone: "Alas, comrade, catch me!" 75

$\mathrm{N}$ [through laughter]: Have you ever said: "Alas, ${ }^{76}$ mother!"

$\mathrm{S}$ [emphatically]: Never! [Through laughter, but adamant]: By my faith, I have never wept!

$\mathrm{N}$ : How is that, since one old man from Herzegovina told me that he chased you when you warred somewhere there with the Montenegrins? That he smoked you [made your feet smoke from running? / blew you off?] over some field?

S: [through laughter, but firmly denying]: Huh, by God, he lies! [Someone interjects with laughter, most likely Parry.] Huh, by God, he didn't even see. ...

In one of the footnotes to the portion of Pričanje I included in SCHS I, Lord provides some "amusing background" to this exchange, noting that the old man who served as an inspiration for the hoax was most likely Mićo Savić (Parry's and Nikola's favorite Christian singer) who fought

${ }^{74}$ Mujo and Halil are among the most famous Muslim heroes of the Bosnian Krajina ("Military Border") and loom large in the South Slavic epic. Referring to Halil as Mujo's (that is, belonging to Mujo) is formulaic and connected to the latter being the older of the two brothers. Mujo is thus seen as being in charge of (and responsible for) his younger brother.

75 The formula invokes a dramatic scene in which a freshly wounded hero entreats a comrade-in-arms to catch him as he is falling to the ground.

76 Rather than simply expressing deep sorrow, the original $(k u k u)$ is an onomatopoeic representation of actual weeping. 
in similar skirmishes as Salih, but on the opposite side. It is likely that the problematic ethics of this joke made Lord slightly uncomfortable, and he concludes the anecdote as follows (330): "Be it said to Salih's credit that he took the joke in the spirit in which it was meant." I wonder, however, whether this assessment is entirely accurate, even though the need to credit Salih with some largesse is urgent and understandable. To be sure, the singer laughs along, but there is a certain uneasiness and insecurity about it, too.

In particular, note how the singer at least gives credence to the possibility that a man somewhere in Herzegovina may have actually made such a claim, and thus he does not say to Nikola: "You made all this up," but rather, "He [the old man from the story] lies." What makes this example especially interesting is that the joke works precisely because of the skill with which Nikola subverts what can tentatively be called the "oral episteme." He first plucks the formula "Woe to me, mother" / "Alas, my mother" out of its epic context and places it in the realm of the everyday, thereby making it ironic. Then he proceeds with his fictitious story, assuming that Salih will give it at least a moment of serious consideration. As epic accounts of recent events start circulating in an oral community, they immediately become subject to scrutiny and censure (Jakobson and Bogatyrev 1971[1929]), with the participants being particularly sensitive about the way in which their feats are portrayed (Kilibarda 1972:94). Nikola thus counts on the fact that the singer's primary concern will be with his honor rather than the probability of the story as a whole. It is precisely the expert understanding of the "oral episteme" that allows Nikola to violate it so effectively and achieve the intended comic effect.

However, one important saving grace in connection with the jokes and teasing of the type discussed thus far is that by the end of the exchange the singer is given some relief by being let in on the joke and invited to laugh along. More problematic and rare (after all, Nikola never comes across as intentionally cruel) are the jokes that the mediator makes more for his own personal pleasure and the benefit of his educated listener(s). On a few occasions he, highly amused and childish himself, copies the singer's faulty pronunciation of "Austria" as "Austuria" (PN 674, VII:4, R 1229), or he feigns passionate opposition to the old man's story so as to wind him up. Thus he sometimes vehemently challenges the truth of the singer's claim that Muslim heroes were more powerful than Christian ones, only too ready to turn off his "anger" so as to remind the singer to state his own obstinate answer more loudly (PN 659, VI:48, R 1053: 0:51-0:52). On another occasion the singer tells a story in which the famed hero Đerđelez Alija shows exceptional nobility (in addition to his celebrated strength) when he saves a Christian village from a dragon to whom the villagers had to sacrifice their young daughters in order to gain access to a well the beast was guarding. However, Salih feels compelled to explain how it is that the second well Alija created when he burst open a stone with his saber was called Đurđeva voda ("George's water"), saying that Alija's feat took place on St. George's Day. Sensing that this explanation is perhaps a bit unconvincing, the ever-quick Nikola uses the opportunity to prod the singer concerning this weakness, knowing it would produce the desired comical effect (PN 656, IV:74, R 993: 2:29-2:44): 


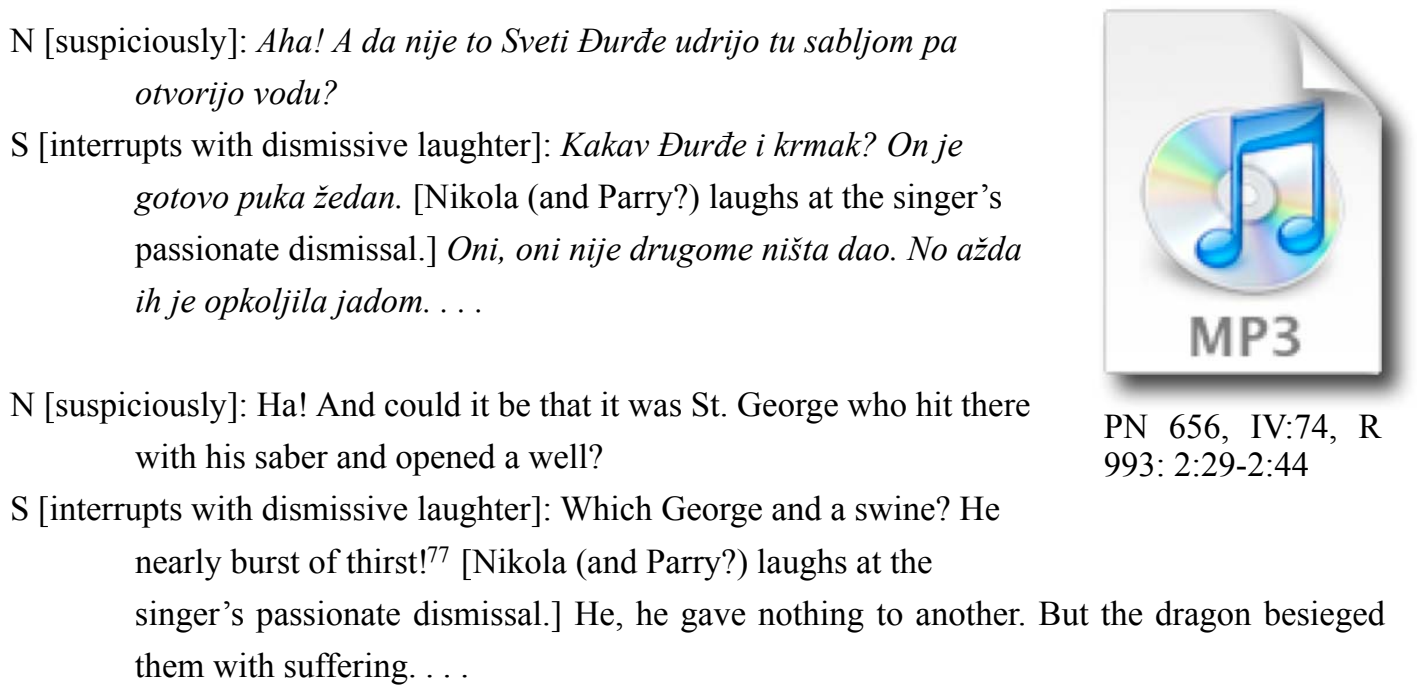

At other times, instead of seemingly antagonizing the singer, Nikola offers exaggerated praise, which he assumes Salih will take not as a cue to tone down his boasting, but to blow his own trumpet with even more gusto. For example, in Pričanje VI (119, R 1072-73) Salih claims that, after hearing the song from another singer only once, he can immediately sing it himselfexactly as heard if not even better - also stating that his manner of singing is superior to Nikola's and to many a singer who viće onako ka goveda da tera ("shouts as though rounding up cattle"). Nikola then compliments the singer: E ti si dedo, bogami "sveznadar" čini mi se ("Eh, by God, it appears to me, you grandpa are a 'know-it-all'"). Sure enough, this fires up the singer: Bogami te jesam belji bio znadar što ga nema niđe, a da mu jebem majku, ovo nebi pisao ni jedan nebi ti mogo kazat ("By God, indeed I was a knower the likes of which you couldn't find anywhere, and fuck his mother, no one else could write ${ }^{78}$ this, no one else tell it to you"). In cases such as these, the singer is not exactly invited to laugh along. Rather, his emotions are manipulated so as to produce a humorous effect.

While it would be entirely wrong to assume that Nikola's (and more rarely Parry's) jokes were cruel - that they were not primarily good-spirited and aimed at relaxing the singer (and themselves!) into what should have felt as the most natural context in which to perform - the instances discussed here do leave the listener wondering to what extent Salih enjoyed them, and whether the young men's conduct towards him was always fair and respectful. More importantly, their discussion here was meant to remind us how, beyond its role as a social leveler and one of the most humane and congenial ways of approaching any "other," humor is not unequivocally positive — or even neutral — and can itself entail epistemic violence.

\footnotetext{
77 What is particularly interesting here is that Salih dismisses only the possibility that St. George created the well but takes his actual existence for granted.

78 Note how the illiterate Salih here makes a meaningful lapse, presenting himself as the one who writes rather than the one who tells. Even though he immediately corrects himself, it is possible that he saw himself as the one writing in effect, if not in fact. Salih's attitudes toward writing are discussed later in the paper, but they are rich and varied and warrant a separate study.
} 


\section{Cognitive and Physical Strain}

As noted at the outset of the article, Parry was interested not only in what songs the Yugoslavian singers sang, how they performed, and what they said about their craft, but also in what songs they could produce if challenged with a specific task, and what they could further reveal about the latent possibilities inherent in their practice and skill. In the preface to SCHS I, Roman Jakobson praises Parry's fieldwork above that of his predecessors, among other reasons because he did not simply take what the singers told him for granted. Rather, all their claims were (1954:xii) "checked by actual experiment." Words such as "test," "verify," and "check" permeate the penultimate paragraph of Jakobson's panegyric. With the hindsight which, all the more to his credit, the illustrious Russian formalist did not have at the time of writing, it is now not difficult to agree with him that (ibid.:xi) "the harvest from this fieldwork" was indeed "unique," rich, and paradigm-shifting precisely because of Parry's thorough probing and experimentation. However, the cost of such harvest in terms of the cognitive and physical strain it placed on the singers has not been given much attention. Indeed, experimentation that involves living creatures by its nature regularly entails violence (even if consensual), as it usually requires that the subjects be taken out of their comfort zones. It also implies a certain intensity of the procedure, as the economic and logistical limitations rarely allow the experimenter much leisure time. $^{79}$ More importantly — as in the case of the Yugoslavian singers - the speed, agility, and endurance in performing set tasks are often among the very things the subjects are tested for, and hence psychosomatic strain is certain.

In terms of shedding light on this procedural and, from the present point in time, ethically challenging side of Parry's experiments, the interviews with the singers are greatly enlightening -in particular those with Salih Ugljanin, not least because of the singer's advanced age. In addition to sharing his usual (and rather bulky) repertoire of songs and stories for protracted periods of time, old Salih was asked to perform bardic feats that he had never before attempted. These tasks ranged from those to which he could adapt with relative ease - such as transforming the heroic lore that he knew and told as stories into actual epic songs (e. g., PN 652, I:59, 75, R 874,879 ) - to more awkward ones - such as extemporizing an epic song about the decidedly non-epic event of his encounter with Parry and Nikola (PN 655, III:105-07, R 965-66) - and on to those tasks that were incomprehensible to him, or simply tedious - such as reciting a song in Albanian and then "translating" it in rapid succession into Bosnian/Serbian and vice versa (e. g., PN 654, II:6-8, 13, R 907-08, 910). ${ }^{80}$ In this last case, even the collector and interpreter occasionally became confused about which language they wanted a song translated from or into (e. g., PN 654, II:6, R 907; PN 656, IV:29, R 981; PN 659 VI:59, R 1058), which reveals how generally counterintuitive this procedure was: if the two could become confused when merely stating their wishes, one can only imagine how difficult it was for Salih to materialize them.

\footnotetext{
${ }^{79}$ On economical and social underpinnings of hurried and selective procedures in ethnographic fieldwork, see Marker 2003:367.

${ }^{80}$ John Kolsti makes a persuasive argument that the singer here is recomposing a song rather than actually translating it (1990:54): "the concept of translating a line from one language to another is as vague to the singer as the idea of repeating a song, or even an episode 'word for word."'
} 
On rare occasions when the singer resists a request, the interviewers often refuse to take "no" for an answer. Thus, for example, in Pjevanje i pričanje (PN 674, VII:36, R 1237) Nikola asks Salih to sing the same song (though preferably an improved and a longer version!) about Đulić Ibrahim which, less then an hour ago, the singer had already dictated to him: E sad ćeš da zaguslaš! ("Eh, now you are going to start playing the gusle!"). Salih immediately agrees to play, but when he timidly suggests that he instead sing another song, Nikola responds with determination: Ovu ćeš ("You will [sing] this one"). Similarly, after being asked to recite the original Albanian version of the song he had just delivered in Bosnian, Salih objects, saying that he has already done so, but just as Parry is about to accept this response, the ever-watchful Nikola intervenes, saying that Salih recited only a few verses and that he should now deliver the full version. The singer stalls awhile, mumbles to himself, and then makes a final desperate attempt to evade the request (PN 655, III:89, R 966): . . . ne hujdiše se (“. . . it doesn't fit”), which will be ineffective against Nikola's disarming humor and relentless enthusiasm: Hujdisat će se ono samo ti pričaj ("It will fit, just you speak"). To counter the singer's resistance, Nikola here readily uses Salih's verb hujdisati $s e,{ }^{81}$ which was in fact unfamiliar to him until the previous day when he actually had to ask for its meaning (see PN 654, II:15-16, R 910). Not surprisingly, the singer gives a little laugh and delivers.

While attempting to meet the collector's complex requests, Salih will often be interrupted in order to be reminded to speak more loudly (e. g., PN 652, I:60, 100, 115, R 875, 883, 890): MP: Malo jače (“A little louder"), Glasnije, glasnije ("Louder, louder”), Samo malo jače ("Just a little louder"). The frequent need for such interventions (especially during the first three interviews) puts further pressure on the singer and occasionally makes him the target of the collector's and his assistant's annoyance. However, no sooner than they snap, the two young men check themselves and try to make light of it, as in the following instance (PN 655, III:78, R 957: 0:31-0:39):

MP: Glasnije. Prićaj glasnije.

$\mathrm{N}$ : Glasnije pričaj stari!

S: Glasnije...

N [now softer, jokingly]: Da se čuje, ja sam malo gluh ja ne čujem.

MP [justifying the outburst]: Kad ja ne čujem dobro odavlen. . . .

[Presumably he is close by.]

S: Znam, znam. ${ }^{82}$

MP: Louder, speak louder!

$\mathrm{N}$ : Speak louder, old man!

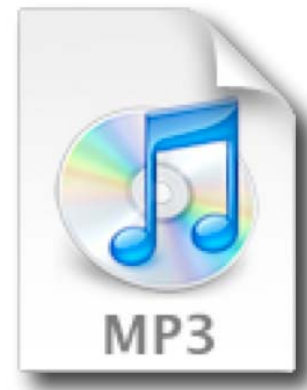

PN 655, III:78, R 957: 0:31-0:39

S: Louder ...

$\mathrm{N}$ [now softer, jokingly]: So that it can be heard, I am a little deaf, I can't hear.

MP [justifying the outburst]: When I can't hear well from here. . . . [Presumably he is close by.]

S: I know, I know.

81 See the entry for ujdisati in Škaljić 1966:630: "to befit," "to suit," "to fit." Kolsti (1990:79) chooses to translate this word more freely as "to adjust."

${ }^{82}$ Not included in the transcript. 
At the end of nearly every poem or story, the singer is asked if that was all, whether there was any more; apparently he is never able to sate the collector's appetite for more and longer stories. Even when he receives positive feedback upon a completed tale (PN 655, III:133, R 973: 2:57-3:38): N: Tako je dedo! ("That's right, grandpa!"); MP: Fina prič ("A fine story"), ${ }^{83}$ the singer is not safe from being asked for more: N: Jeli to kraj te priče? ("Is that the end of that story?”); MP: Hoćeš li još malo? (“Do you want [to tell us] some more?”). And so the singer cannot bask in the glow of a job well done for long, but he must instead scramble for a way to conclude the day's work: Jok! Sad nema vakta više. Teke imaće ako Bog da . . Dok namisljim još koju ovu, ja sam umijo ovije mlogo, pa sam [zaboravio?] . . ("No! There's no more time ... There will be if God permits . . until I can think of some more . . . I knew many like this, but I [forgot?] . .."). At the end of Pričanje IV (PN 656, IV:98, 104, R 1000-01) Salih suggests that they continue working tomorrow, giving as his first reason the great length of the remainder of the song he was reciting and the fact that there is a lot more left for them to do: Pa imamo da pišemo, pa imamo ... ("Then we have to write, then we have to ..."). Then, as a final resort, he goes on to blame his haste on his wife who ćeka tamo, hoću da je ubijem u glavu s ovom .. . ("is waiting for me there ... I'll beat her head in with this ..."). When, after a bout of joint laughter at the old man's jokey pluckiness, ${ }^{84}$ Nikola comes to the woman's rescue: E neka babe . . ("Eh, let grandma be ..."), ${ }^{85}$ Salih realizes he is off the hook and is thus quick to agree that, joking aside, his wife is a good woman who does not deserve harsh treatment: Bogami sirota je dobra ("By God, the poor thing is good"). However, the culmination of Salih's evasive tactics must be towards the end of Pričanje V (137, R 1040), when upon being asked by Nikola to tell još jednu dobru priču ("one more good story"), he refuses, promising instead to go to his literate neighbor that same night to look up a notebook full of stories that were written down from him 40 years earlier. The two young men are suspicious about the existence of this manuscript and ask him to give the most sacred of Albanian oaths, the besa, that he will bring it along with him the next morning. Salih immediately agrees, but not without a caveat, which he repeats in three consecutive sentences (PN 658, V:140, R 1040): ako ga nađem . . . ako nađem . . čim nađem ("if I find him ... . if I find . . . as soon as I find"). Like Scheherazade, Salih obtains his temporary respite by whetting the appetite of his listeners, enhancing their anticipation and coaxing them into a suspension of the current proceedings. Unlike the legendary Persian queen, however, the flesh-and-blood singer does not always deliver on his promises. Thus, in the end he is unable to produce the illusory notebook, and he is further unwilling to let Nikola and Parry accompany him to the neighbor to purchase the manuscript from him. Salih similarly betrays the two men's expectations when, after promising that the quantity of verses of the "Two Sultanas" would match the one delivered towards the end of Pričanje IV (c. 348), the following day he recites only a further 90 verses.

\footnotetext{
${ }^{83}$ Not included in the transcript.

${ }^{84}$ It is clear to everyone present that Salih means his wife no real harm.

85 In the transcript, this utterance is rendered as: E neka babe, to je ("Eh, let grandma be, it/that is"), followed by an empty space to indicate that the rest is inaudible. While, after repeated and careful listening, I cannot make out what Nikola says here, I am certain that it is not to je. Presumably it is something in further defense of "grandma," but it is impossible to tell precisely what.
} 
Still, it should be said that Salih usually becomes evasive in the ways described only after first being placed under a great deal of strain. For instance, after the first 259 verses of the "Two Sultanas," 86 the singer asks for a break, stating that he is already tired and that a lot more of the song remains (at this point there is indeed a bit less than half of the song left). However, the two young men keep insisting that he continue, themselves promising to soon call it a day (PN 656, IV:98-99, R 1000): PP: Još malo i onda ("Just a little bit more and then"); N: Još malo pa ćemo ić ća, kad si se umorijo ić ćemo ća ("Just a little more and then we'll go; since you are tired, we'll go"). When after another 89 verses Salih stops for the second time and gives a negative answer to Parry as to whether the song is finished, the two young men do not hurry to honor their earlier promise but instead attempt to make him complete the song. At this point it is tempting to consider (but impossible to claim with certainty) whether, when Salih subsequently tells Nikola there is as much of the song left to recite, he was purposefully ambiguous and did not have in mind all the $348(259+89)$ verses, but in fact only those 89 that he recited in between the two breaks. That way, having delivered 90 verses the next day, he would have both told the truth and misled the interviewers into letting him go home when he wished. Of course, I do not mean to suggest that Salih could have calculated (as I have) the length of the remainder of the song in terms of the number of verses, but that he nevertheless could have made such an estimate in terms of the time it would take him to finish it. At any rate, this is only a conjecture, one of the points of indecision that I have included as a way to resist the "efficiency" and feigned confidence of academic mannerisms that would often conceal such uncertainties, lest the "more solid" arguments suffer the consequences of such flights of fancy.

Indeed, even though the two young men generally show concern for Salih's well-being, ${ }^{87}$ the collector's desire for continuous and long narratives and the native's task of ensuring that the foreign scholar receives value for his money will time and again blind them to the fact that old Salih needs a rest or is actually in pain (PN 659, VI:92-93, R 1066: 2:03-2:37; PN 654, II:67-68, R 928: 2:19-2:50):

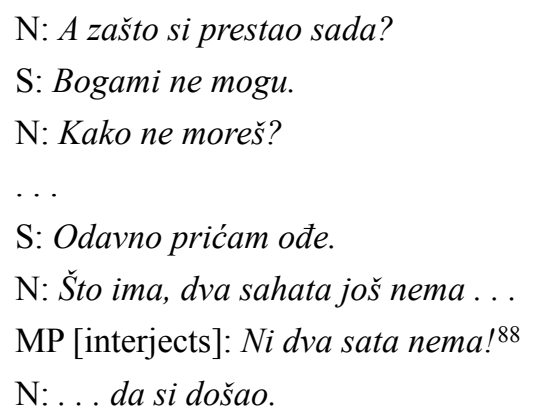

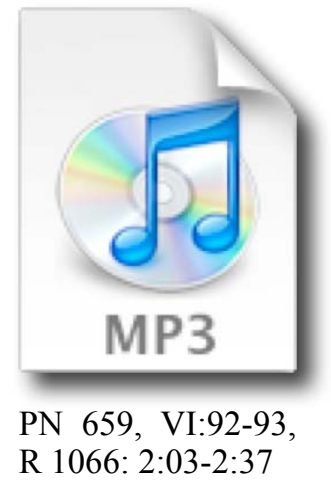

R 1066: 2:03-2:37

\footnotetext{
86 Note that Salih began reciting this song a few times that day. One of these times was the previously discussed instance when Parry and Nikola played a practical joke on him.

87 Nikola, for instance, asks the singer whether he is tired (PN 654, II:96, R 937) and Parry even orders refreshments (PN 654, II:67-68, R 928).

${ }^{88}$ Not included in the transcript.
} 
S: Bogami . . ${ }^{89}$

$\mathrm{N}$ I I va si puta počivao!

S: Pa jes no hej duša jedna, nemore, nemore da je konj.

N [complimenting and chiding all at once]: Da ja imam pričat koliko ti ja bi pričao deset dana, ne bi nikada prestao.

$\mathrm{N}$ : And why have you stopped now?

S: By God, I can't.

N: How come you can't?

.

S: I've been talking here for ages.

$\mathrm{N}$ : What is there, there's not yet two hours ...

MP [interjects]: Not even two hours!

$\mathrm{N}$ : ... since you came.

S: By God ...

$\mathrm{N}$ : And twice you rested!

S: Well, yes, but hey, there's only one soul [I have], it can't, it couldn't if it were a horse.

$\mathrm{N}$ [complimenting and chiding all at once]: If I had as much to tell as you, I would talk for ten days; I would never stop.

$\mathrm{S}$ [halting mid-recitation]: Iju! 90

MP [barely audible]: Što ti kažě̌? ${ }^{91}$

$\mathrm{S}$ [to Parry, through a quick painful laugh]: . . . Zohar mi ovde, nešto me zabolje.

$\mathrm{N}$ : Što ti je bilo?

$\mathrm{S}$ : Đe prićam ...

N: Nemoj ti prekinut sad. Pričaj naprijed.

$\mathrm{S}:$ Ne mogu, đe pričam . . .

MP: Eh mi ćemo poćinut, poćivati malo. Dobro je za kafu.

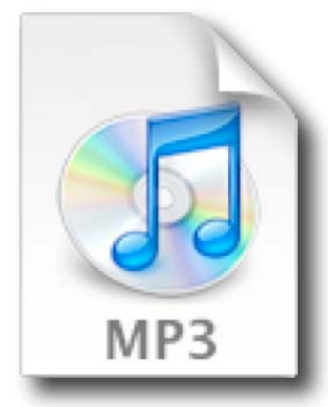

PN 654, II:67-68, R 928: 2:19-2:50

$\mathrm{S}:$ Da poćinem.

MP: $D a$.

S: Sam da malo se odmorim.

N: Samo nemoj zaboravit, đe si osto.

S: Jok.

$\mathrm{S}$ [halting mid-recitation]: Ouch!

MP [barely audible]: What do you say?

S [to Parry, through a quick painful laugh]: . . . [I feel pain] here, something started to hurt ...

\footnotetext{
${ }^{89}$ Not included in the transcript.

${ }^{90}$ Not included in the transcript.

${ }^{91}$ Not included in the transcript.
} 


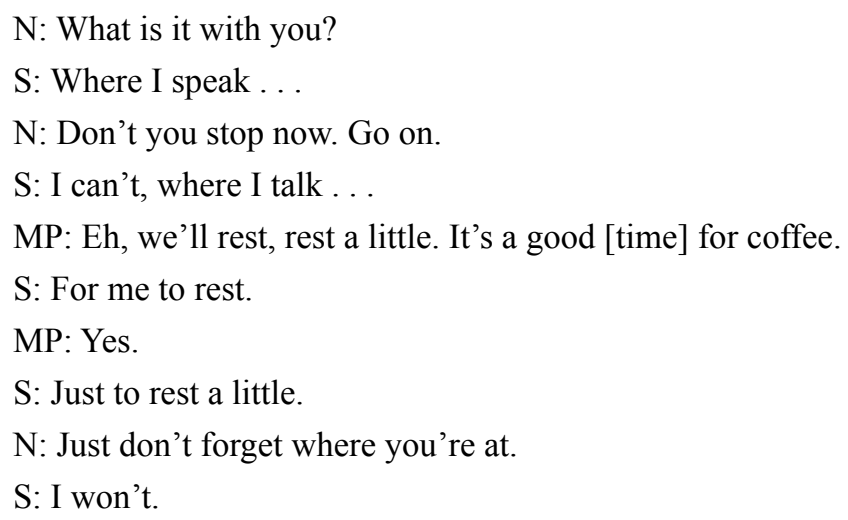

Of course, continually asking for more and longer stories was for Parry a good way of testing whether any single person would be able to produce narratives of the size of the Homeric epics. That the collector is primarily after long songs and stories seems to have been clear to the singer, too, and from day one, ${ }^{92}$ since he feels the need to alert the interviewers when a song they are discussing is only a short one and therefore may not be of their interest (e. g., PN 658, V:54, R 1015): A nije dugaćko znaš, kratka je ("But it [the song] isn't long, you know, it's short"). Testing for possibilities of length and "fullness" will often push the singer away from his habitual way of rendering a story, which - as Parry's other experiments show-itself varies depending on the audience, the immediate context of performance, and the singer's momentary inclinations but at least accords with his own notions of truth and correctness. ${ }^{93}$ However, some of Parry's attempts to obtain from Salih the hypothetical "complete" and "definitive" song on occasion imperil the singer's raison d'etre as the custodian of communal memory. For instance, when in Pričanje VI (113-14, R 1071) Salih ends the song he was reciting with the wedding of the hero Halil, Nikola asks doubtfully: Šta je to kraj? ("What is that, the end?"). As the singer confirms he is finished, the interpreter and the collector both then point to missed narrative opportunities as though they were not merely junctures for the singer to engage with or dispose of material while negotiating between his creative proclivities and responsibilities towards the communal truth, but rather points where he had failed to reproduce the song "correctly." For instance, since the hero marries in the end, Nikola teases Salih for not having used the traditional closing formula: Da je ljubi kad god se probudi ("To kiss her whenever he wakes up"). Even though Salih at first resists, appealing to his own knowledge of the "correct" version of the story (Vala to ljubljenje ${ }^{94}$ nema; "Well that kissing isn't there"), he eventually relents; after all, he is not being asked to compromise on how the actual events are related. Thus, he adds a further 17 lines of the formula expressing good wishes with regard to the prospective progeny of the happy couple. Not even this addition proves satisfactory enough, however, and the singer is spurred on further, this time by Parry: Hajde naprijed. . . . Ali njesi rekao ništa za našega sultana ("Go on

${ }^{92}$ See PN 652, I:34, 48, R 867, 871. Also: PN 654, II:28, R 915; PN 659, VI:57, R 1053.

${ }^{93}$ For a discussion of the ways in which notions of truth and correctness may vary from singer to singer, see, for example, Elmer 2010. Similarly, I discuss elsewhere (2012) how the same singer may assign different truthvalues to different songs in his own repertoire.

${ }^{94}$ Nikola does not transcribe the word, but the singer can be heard saying it. 
further. . . But you haven't said anything about our sultan"), upon which he adds another seven verses.

The described scene is, however, only a comical prelude to the final interview which was to take place four days later when, as Lord comments (SCHS I:352) "pressure was being brought to bear upon Salih to tell a full story and leave nothing out." Lord's description of what transpired as "pressure" (and in another place [341]: "vigorous questioning") hardly does justice to the epistemic onslaught that Nikola and Parry launched against the logic, truth, and aesthetics of Salih's song about Đulić Ibrahim, questioning both his abilities as a singer and the local tradition as a whole. Dissatisfied with the song Salih dictated to Nikola earlier in the day, they wanted to ensure that the version he was yet to deliver for the recording (to the accompaniment of the gusle) was a superior one. Hence, they begin interrogating the singer about the weaker points of his song, their questioning directly or indirectly suggesting ways in which it could be improved (improved, that is, in accordance with their own assumptions about coherence, plausibility, and narrative logic). In comparison with the previous six interviews, the ferocity and intensity of the last one is especially striking, as indeed is the slippage from the characteristic leisurely, humorous tone to an urgent, accusatory, and occasionally even offensive one. Thus, when Salih refuses to give in to the collector's persistent attempts to force him effectively to invent what Đulić's mother and sister said upon learning of his death ${ }^{95}$ and then also dismisses Nikola's formulaic suggestions (e. g., PN 674, VII:15, R 1232: Sunce moje rano ti mi zađe! ["My sun, you set early on me!']), Parry seems to lose patience. He proceeds to postulate his reasoning as superior and closer to the "truth" than Salih's song presents it (PN 674, VII:14, 16, R 1232): Sigurno da je majka rekla nešto ("For sure the mother had said something"); Sigurno da je rekla nešto ("For sure she had said something") - and he also openly casts doubt upon the singer's abilities (PN 674, VII:18, 36, R 1233, 1237): Sigurno da bi dobar pjevač rekao kako su rekle majka i sestra ("Surely, a good singer would have said what the mother and the sister had said"); E mi tražimo pjevače, pjevače koji kažu cijelu pjesmu ("Well, we are looking for singers, singers who tell the whole song"). Furthermore, he goes so far as to deride the two female characters who he knows must have represented for Salih (and the tradition at large) patriarchal ideals of every motherly and sisterly virtue (PN 674, VII:19, R 1233): Nijesu bile mudre. . . Budale su bile ("They were not wise. . . . They were fools"). Of course, this derision forms part of Parry's reverse psychology tactics aimed at provoking Salih into delivering a better song. Had he truly believed what he implied - that is, that Salih was a bad singer-he would have most likely not bothered to apply his "pedagogical" skills in the first place. Rather, he must have recognized in the singer aspects of what he imagined would be a true Homeric bard - the very creature he came searching for in the Balkans-whom he will, as it turns out, encounter only the following summer in the guise of Avdo Međedović from Bijelo Polje. Nevertheless, whatever Parry's ultimate aims and "true" assumptions about Salih were, this episode highlights the dangers inherent in the method, with the situational contingencies pushing the line of questioning in directions that blur encouragement and personal annoyance-thus compromising the results of the experiment.

95 The singer claims that they simply wept, even suggesting that they may have been too shocked to say anything. 
Here the interpreter characteristically quickly follows where the collector leads, which only escalates the situation. Thus, while on many previous occasions, if perhaps only by way of encouragement, Nikola has exhibited (or enacted) an utmost, implicit belief in the singer's truthful telling of epic events (e. g., PN 655, III:7, R 939: Kako ono bi? Kako je bilo Salja?; "How did that happen? How was it Salja?"), he now ridicules Salih's logic for claiming that the hero entered a room alone and cut off 50 enemy heads, as though such a hyperbolic feat had suddenly become something entirely unknown to the epic (PN 674, VII:23, R 1234): Dobro, a šta su radili ono pedeset ljudi, biće da su skupili ruke pa stali, za pasom s rukama ("All right, and what were those 50 people doing, they must have folded their arms and stood with their hands tucked inside their belts?'). The singer ventures a guess that the unsuspecting enemies' weapons were out of reach, but he is then criticized first for not having mentioned this circumstance during the recitation, and then for his yet again faulty reasoning, with Nikola pointing out that there usually are such objects in a room (chairs, tables) that one can use for defense against a saber until the greater numbers can overpower a single armed attacker. The singer makes one more desperate attempt at rationalization (PN 674, VII:24, R 1234): Oštra sablja ona išteti pamet ("A sharp saber, it can impair one's wits"), but after this explanation is promptly dismissed by Nikola: Nemoguce to ("Impossible, that"), he finally defers to the ultimate authority — that of the tradition (PN 674, VII:24-25, R 1234: 3:03-4:10):

\section{S: E pa oni tako pjevaju. ${ }^{96}$}

MP: Tako pjevaju?

S: $E$.

MP [argumentatively]: Ali je li dobro da tako pjevaju?

$\mathrm{N}$ [clarifying]: Jeli to istina valja čut?

MP: Jeli bila istina? Ako nije bila istina zašto se pjeva?

$\mathrm{S}$ [adamant]: E pa, on da nije istina, nebi ga on pevao.

...

$\mathrm{S}$ [on Parry's suggestion to include all this subsequent reasoning in his

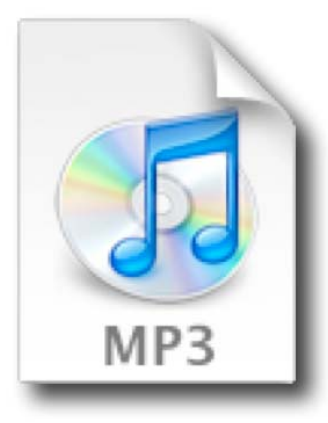

PN 674, VII:24-25,

R 1234: 3:03-4:10 song]: E oni ne kazuju da je imao koji oruža, da se digao na njega da učini huđum, niko.

$\mathrm{N}$ [teasingly]: Sigurno si ti preskočijo.

$\mathrm{S}$ [emphatically, imitating Nikola's contesting tone]: Nijesam. ${ }^{97}$

$\mathrm{N}$ : E dobro!

MP [interjects passionately]: Mislim ${ }^{98}$ da loši pjevač kaže samo da je, Haljil, odsjekao pedeset glava, tako, ali da dobar pjevač bi rekao tačno.

$\mathrm{S}$ [not following]: $\mathrm{Ha}$ !

${ }^{96}$ Not included in the transcript.

97 Nikola here adds vala, the word used for emphasis. However, I cannot make it out while listening to the recording. It is also possible that Nikola added it mechanically, as Salih did answer emphatically.

98 In the transcript, Nikola renders the beginning of Parry’s remark as znaš li ("do you know”), rather than mislim ("I think"), which is what I hear here. 
MP [explaining]: Kako je bilo, zašto je mogo da k, o, osjeć [laughs at own stammering], osječe toliko glava.

S: Well, they sing it like that.

MP: They sing it like that?

S: Yes.

MP [argumentatively]: But is it good that they sing it like that?

$\mathrm{N}$ [clarifying]: Is that the truth? It should be heard?

MP: Was that the truth? If it wasn't the truth, why is it sung [like that]?

$\mathrm{S}$ [adamant]: Well, he . . . if it wasn't true, he [the singer from whom he learned the song?] wouldn't have sung it.

$\cdots$

S [on Parry's suggestion to include all this subsequent reasoning in his song]: Well, they don't say if anyone had weapons ... that he got up to attack him, no one ...

$\mathrm{N}$ [teasingly]: You have skipped [something] for sure.

$\mathrm{S}$ [emphatically, imitating Nikola's contesting tone]: I haven't.

$\mathrm{N}$ : Well, OK.

MP [interjects passionately]: I think that a bad singer only says that Halil cut off fifty heads, like that, but a good singer would tell it correctly ...

$\mathrm{S}$ [not following]: Ha?!

MP [explaining]: . . . as it was, how come he was able to, c-, c-, cut [laughs at own stammering], cut off that many heads.

Again, a feeling of acute inadequacy as a singer and custodian of communal memory is being imposed upon Salih who is further confronted with two distressing options: either he told the untruth himself (and badly at that) or the fault lies with his predecessor (whom he deemed a good singer ${ }^{99}$ ) and possibly the entire tradition passed down to Salih and trusted by him implicitly ("But is it good that they sing it like that?"). Parry even proceeds to lay the ultimate claim to truth, offering his own (thus obviously more plausible!) "reconstruction" of events and pressing the singer to agree that that is what actually transpired (PN 674, VII:28, R 1235): Tako je bilo istina jeli? ("That's how it truly was, wasn't it?").

In addition to being accused of having strayed from the truth, the singer also faces renewed accusations of skipping lines from an imposed monolithic construct of a song. That in Salih's world the "same" song can be short yet complete, and long yet featuring no superfluous material, is one of several such realizations - born from epistemic probing of singers - that remain so difficult and counterintuitive to us as literates more than 50 years after The Singer of Tales. ${ }^{100}$ However, at this point of the interview, through his own experience of song-making and

\footnotetext{
${ }^{99}$ See PN 674, VII:35, R 1237: N: Jeli bijo dobar pjevač? S: Vala jes. (N: "Was he a good singer?" S: "Yes indeed.")

100 See, for example, David Elmer's recent discussion (2010) of the South Slavic singers' different yet equally valid or "normative" stances towards okićenje ("performance"). In particular, see his critique of Zlatan Čolaković (283-90).
} 
performance, the singer can resist but not actually dismiss the interviewers' ideal song construct. It is, after all, coming from figures of authority, the representatives of the literates who already dominated the social, political, economic, and cultural fabric of the country in which Salih was living; as an obviously more successful caste, they could thus claim superior knowledge.

While Parry's immediate goal to arrive at an improved version of the song about the captivity of Đulić Ibrahim ultimately fails, ${ }^{101}$ the cognitive and emotional ordeal to which, with Nikola's able assistance, he subjects Salih will nevertheless result in an abundant number of insights into the functioning of oral tradition and the nature of oral narratives. While Salih is obviously destabilized in the process, forced to scramble for explanations - which, as long as they remained within the rules of the imposed discourse, failed-the important thing to notice is how the singer destabilizes his interviewers in turn by continually breaking these imposed rules. The more aggressively he is challenged about the truth of his story, the more vehemently he defends it, persistently rejecting the interviewers' alternative scenarios and invoking the ultimate authority of tradition as the bottom line. When they think they have cornered him with their logical snares, he in turn ensnares them with one of his own, whereupon the song is true because people sing it that way, and they sing it that way because what it describes is true-otherwise why sing it? When they claim he has skipped something, he promptly quotes back the verses from his song as proof that he did not. When they demand cool, considered, cogent speech, he responds with a heated immediacy and the suggestiveness of onomatopoeia (PN 674, VII:25-26, R 1235): A da Bogami tu je sekao lasno. Udarijo na red, klapa, klupa, klapa, klupa, hajt, hajt, hajt, hajt, dok je poredijo ("Ah yes, by God he [Halil] cut there easily. He hit them in turn swish, swash, swish, swash, go, go, go, go, until he [cut them all] in a row"). When they ridicule his reasoning, he sniggers in turn at the kind of knowledge they presume to expect from an epic song (PN 674, VII:34, R 1236): e pa ko ti zna? ("Eh, well, who knows?," "Whoever could tell you that?," and "What a silly question!" all subsumed in this one sentence and the way it is intoned).

While the kind of epistemic violence perpetrated by the interviewers is of a more conspicuous nature, Salih's resistance (even if the term accurately evokes reactive rather than initiatory violence) was exquisitely aggressive in turn-resulting in Parry's (and also Lord's) own cognitive straining. It forced these enthusiastic students of oral literature (whose initial training, intuitions, and critical tools were nevertheless literary) to appreciate more fully that a value is a value only according to a measure, not because it holds universal currency, and that it was thus necessary to relinquish any residual claims on textual accuracy, completeness, truthfulness, and other such "clichés of another criticism" (Lord 2000[1960]:65). It taught them not to take for granted even the meaning of seemingly simple and self-explanatory words, such as the word "word."102 It is in this clash of two apparently incommensurable worlds, in this

${ }^{101} \mathrm{I}$ base this assessment on that made by Albert Lord, taking it as likely to have coincided with that of his teacher (1954:354): "The dictated No. 6 is, as usual, better than the sung No. 4."

102 See, for example, Lord 2000[1960]:28. As John Miles Foley writes (2007:9): "For Kukuruzović, and for other guslari as well, a 'word' had no relation to our typographically defined item; it was a larger, composite unit consisting of not a single but rather multiple written words . . . the term reč can also designate a speech, a scene, a narrative increment, and even an entire story-performance. . . . Anything smaller than a 'word'-one of our typographical words, for example_-just doesn't register as a cognitive chunk." 
unique "out of joint" space where both were forced to regard themselves in the twisted mirror of the other, that a new episteme was born.

\section{Countering Epistemic Violence: Salih versus Nikola and Parry}

In scholarly discussions on epistemic violence, one inadvertent form of epistemic violence often committed in the same breath is the unstated privileging of the scholarly arena as the ultimate (that is, frameless, "placeless") arena where the voice of the other is to be heard or else its inaudibility bemoaned. In her criticism of the current discourse on otherness, bell hooks specifically points to this problem of a relevant space in which to engage with these questions (1999:342):

I was made "other" there in that space with them [fellow scholars]. In that space in the margins, that lived-in segregated world of my past and present, I was not "other." They did not meet me there in that space. They met me at the center.

Although of utmost importance, the question of whether the subaltern can speak should perhaps also be accompanied by other questions, such as where could the subaltern speak and who would be there to hear if/when s/he does. Does one's having or not having a voice also depend on who is listening - an occupier, a foreign scholar, a local government official, one's sibling, a friend over a coffee in the privacy of one's home, or a peer in the local coffee-house, at once a place of great intimacy and a battleground over prestige and communal standing? And whose response will count most, in which situations, and about what topic? In other words, are not the listener and the context of utterance constitutive parts of the speaker's voice?

In the present context, it would be instructive to know what stories Salih told about his encounter with the American scholar and his native assistant, and how he conveyed them to people in places that mattered to him: his family, his neighbors and close friends, the fellow singers from the same area, and the owners and frequenters of the kafanas in which he sang. Of course, we cannot hope to access these stories, but it is possible to venture a guess that, while these stories probably all had slightly different slants (depending upon the desired effects on each target audience), it is likely that in all of them Salih was the main character; that, whether he praised or poked fun at his "bosses," he invariably came out on top. As mentioned before, the figure of the lowly man who outwits the high and mighty was prominent enough in the tradition that it did not require a great stretch of imagination for Salih to identify with this character. Moreover, there are humorous stories that specifically treat foreign travelers, stories that, having already been published in the late nineteenth and early twentieth centuries, seem to indicate they began circulating orally as soon as the explorers of all hues discovered an interest in the peoples and cultures of the Balkans. Of particular interest is one such story (originally published in 1902) that actually involves a foreign scholar who came da ispituje ("to explore;" literally "to 
interrogate") the Montenegrin people. ${ }^{103}$ After asking his first unsuspecting "subject" a few questions (for instance, what the name of Christ's mother was), the Montenegrin stops him to ask in turn whether he knows what his mother's name is. Upon receiving a negative answer, the "subject" concludes that because his interrogator does not know something that his whole village knows, he probably knows nothing at all (Đurić 1977:364): Stranac, videći da je na prvom koraku ograisao, okani se ispitivanja, i povrati se oklen je i došao . . . ("The foreigner, seeing that he came to grief at the first step, gave up his research [interrogation] and went back where he came from ....").

While I cannot claim that Salih in particular felt exactly as the Montenegrin from the story, or that he cast himself in a similar role when telling his friends and family about his encounters with Parry, I think the tale provides a very useful background against which to view Salih's own resistance. Indeed, to the extent to which this story is indeed a part of folk lore, it can be said that it encapsulates general attitudes towards the scholarly invaders and testifies to the natives' desire to beat them at their own game of knowledge and wits. In other words, the story seems to bear witness to the people's recognition of attempted epistemic subjection and their desire to resist it and strike back. Of course, it also bears witness to the patriotic desires and nationalist zeal of the native collectors who deemed such stories potentially appealing to their readership and thus publishable, but the fact remains that these tales were first told, that people efficiently continued to use their age-old medium in order to deal with rather new experiences, and that they continued to tell each other stories - their stories - that they could speak. Inasmuch as this is the case, Gayatri Spivak would, quite rightly, question their subaltern status. However, if such stories did not happen to serve the current interests of those with the power to publish/ record, would we have ever known that indeed there was a place where they could, or even wanted to, speak about these matters? ${ }^{104}$

Even if such open confrontation and the neat, unequivocal victory for the "home team" that one encounters in the Stranac i Crnogorac ("Foreigner and Montenegrin") remain the matter of humorous tales, the interviews with Salih also offer important insights into the ways of countering epistemic probing. As we shall soon see, these are subtler and messier, but also ultimately more effective: unlike the Montenegrin from the story who, by putting the foreigner "in his place," reinstates the status quo, Salih and other singers will, by both making themselves

103 I am greatly indebted to Dr. Sonja Petrović of the University of Belgrade for kindly presenting my children with a book in which, quite serendipitously, I first came across this story. However, I am even more grateful to Sonja for her subsequent effort in tracing for me the original source of its publication (Grđic Bjelokosić 1902), for suggesting other similar stories to read, for sacrificing her scarce free time to scan the essential yet for me inaccessible scholarly material, for offering heaps of helpful advice at various stages of this project, and, last but not least, for being an excellent colleague and a friend.

104 For example, the contemporary Serbian guslari often censor their repertoires when facing a university researcher (even if the latter is a compatriot). They are very forward when it comes to performing what they deem to be the songs that a scholarly audience is likely to appreciate - that is, those of proven aesthetic quality and socially acceptable ethical values, such as the songs from Karadžić's collections. However, they tend to be guarded and evasive when it comes to the songs of local significance and a personal nature, or those that treat more recent events, such as the 1990s wars in the former Yugoslavia, the songs whose content (for instance, the glorification of Slobodan Milošević) they judge might be politically and ethically controversial. According to Smiljana Đorđević (2005), before performing these latter types of songs, the guslari would first try to get to know their listener(s) better and would need a lot of reassurance and upfront approval. 
vulnerable to the epistemic probing of the foreign scholars and simultaneously resisting it, affect and change their visitors' own epistemic frameworks.

\section{The Power of Tradition}

As briefly touched upon earlier, one of the most effective means by which Salih deflects Parry's and Nikola's strikes against the logic, completeness, and truth of his songs is not his engagement with these challenges on their proposed terms (that is, by "rationalizing"), but his resistance to them from within his own cognitive paradigms, those supplied by his tradition. For instance, the most effective defense that the singer puts up during the exhausting questioning session about the various "weak" points of the song "Captivity of Đulić Ibrahim" occurs when he repeats or re-narrates the disputed scenes (instead of offering the expected short, pointed explanations), usually starting with a prose retelling and then slipping into actual recitation (e. g., PN 674, VII:8, 11-13, R 1231-32). In this way, Salih not only repeatedly rejects Parry's imposition of a "fuller" song scenario, but he does so through the very act of that repetition. The repetition itself renders the disputed passage as self-evidently what it is, giving it the persistence required to stand as evidence. As such, it becomes an oral document and a proof that Salih himself wields. Such responses are, of course, not unheard of from performers asked to translate the meaning of their work. Pina Bausch, for example, the great German choreographer of Tanztheater, gave a similar response to an invitation to deliver a series of lectures at Stanford. Rather than quenching our thirst to "know" the meaning of her work, she simply had her dancers perform some more. Assuredly, Pina had more practice than Salih at dealing with this kind of pressure and had more time to think about it. She would sometimes tell the apocryphal story about how the composer Beethoven likewise played an entire piece again when someone asked him what it meant. ${ }^{105}$ Apparently, for Pina, Beethoven, and Salih, their "work just is" (Climenhaga 2009:40).

The best the two young men can do in this situation is to claim that the singer skipped verses (e. g., PN 674, VII:13, 14, R 1232): N: Ti si preskočio tu meni se čini; MP: Ne, ne; ne, ne, ali si preskočio (N: "It appears to me you skipped [things] there;" MP: "No, no; no, no, but you skipped"). However, they cannot offer any immediate proof for these claims since, unlike the singer, they do not have a way to access the song instantly. Salih's ability to circumvent their logical challenges in this way proves frustrating (especially for Parry, as his is the most serious investment in these proceedings) and serves as an effective deterrent against the smug attitude the two men often assume towards him during the course of this interview. For example, after all his persistent and clever attempts to make the singer see just how plausible and necessary it would have been for Đulić's mother and sister not merely to cry but to honor the hero with a proper lament, Parry realizes that, against his generic expectations regarding an answer, Salih will respond with yet another round of verses. He thus quickly tries to cut off the old man (PN 674, VII:16, R 1232: 3:39-3:42): Dobro, dobro, dobro . . . dobro za to ("All right, all right, all

105 This probably is an apocryphal story, but the fact that it is so often repeated by composers, artists, writers, and performers does not seem to detract from the point either. 
right . . . all right [i. e., enough] about that!"). ${ }^{106}$ The words as quoted here hardly do justice to Parry's helplessness and annoyance at the unheeding singer who carries on, already moving beyond Đulic's mother's and sister's wordless crying onto the hero's own reaction to the two women's inability to recognize in the bearer of the grave news their own disguised (and very much alive!) son and brother. While Nikola eventually manages what Parry could not and makes the singer stop reciting, he does so only by also letting the matter of Đulić's mother and sister rest and then starting an altogether different line of questioning. However, that Parry will not be able to let go of his failure but will soon come back to the same topic with renewed and uncharacteristic passion, deriding the singer and the two female characters in the process, testifies to the profoundly unsettling impact of Salih's reliance on his own knowledge, skill, and obstinate invocation of tradition as he knows it.

The singer's profuse usage of epic formulas in the narration of not only his epic tales but also "real life" events as well may have presented another cognitively challenging factor for the collector. Thus, for example, when Salih tells of his encounter with the Serbian sergeant Uroš from Rogozno, who so appreciated his poetic acumen that he begged him to sing regardless of whether the Serbs or Muslims won the day, we are told that the sergeant's company numbered "32 comrades" (trides $i$ dva druga; PN 655, III:50, R 949). What makes this otherwise inconspicuous number stand out is the fact that Marko Kraljević (PN 652, I:35, R 867), Ahmet the standard-bearer (PN 656, IV:15, R 977), Mujo of Kladuša (PN 658, V:12, R 1004), Bojičić Alija (PN 659, VI:73, R 1061), Velagić Selim (PN 674, VII:6, R 1229), and nearly every other epic hero in Salih's songs also tend to be accompanied by "thirty-two comrades."107 Similarly, Salih tells of how his teacher, the legendary Ćor Huso Husović from Kolašin, had been awarded by the Austrian emperor Franz Joseph (PN 652, I:10, R 860) sto ovaca $i$ sto napoljona ("a hundred sheep and a hundred napoleons"), which is not only a formula modeled on sto ovaca $i$ sto jaganjaca ("a hundred sheep and a hundred lambs"), but is also rendered in flawless decasyllabic meter. In fact, when later in the day, the singer is asked to "remind" Nikola of how much Ćor Huso received from Franz Joseph, he will actually reply (I:86, R 882): sto ovaca i pod njima sto jagaca ("a hundred sheep and under them a hundred lambs"), ${ }^{108}$ quickly adding: I dao mu je sto napoljiona ("And he gave him a hundred napoleons"). It is interesting to note that, in comparison to his former use of the word, the singer here has an extra "i" in "napoleons" (napoljiona, rather than napoljona). This pronunciation seems to suggest that he dropped the vowel " $i$ " from the previous instance in order for the word to fit the decasyllabic meter.

On the face of it, this usage is not so unusual, and Nikola also often employs epic formulas in his conversations with Salih. For instance, he asks if the singer himself ever cried out

106 The transcript has: Dobro, dobro Salihe ("All right, all right, Salih"), but I wrote here what I heard upon repeatedly listening to the recording.

107 This number seems to be the singer's personal formula. In the South Slavic traditions (both Christian and Muslim), 30 (e. g., trides'kapetana/“thirty captains") is much more common.

108 Compare this instance to the verses of Salih's prosimetric narrative about Golalija that appears 17 pages later (PN 652, I:103, R 887): nabavijo hiljadu ovaca / i pod njima hiljadu jagaca ("he got himself a thousand sheep / and under them a thousand lambs"). Note how the number of sheep is now a thousand (still a multiple of ten) to better accommodate the decasyllabic meter. 
to his mother (PN 655, III:63-64, R 953: 0:21-0:23, see above), inquires as to whether Albanians are indeed ljuti Arnauti ("fierce Albanians") as the tradition has it (PN 654, III:4, R 938: $3: 22-3: 25)$, and upon hearing that a hero from Salih's story died a natural death, he commentsto the singer's approval— that he was killed (II:35, R 919: 0:17-0:20) Ni od puške, ni od noža, no od Boga, staroga krvnika ("Not by rifle, nor by knife, but by God, the old executioner"). However, for the literate singer Nikola, epic formulas clearly belong in the context of epic poetry, and thus when he employs them away from that particular context (as is the case here), he does so with light ironic distance and in a jocular tone. That there is no such distance in Salih's own usage (epic or everyday) suggests that formulas are for him not simply a part of what we now call "traditional poetic idiom," but are in fact constitutive of his general cognitive apparatus. For Parry (and Lord, too) such a confluence of the everyday and the traditional would have been counterintuitive not merely because it made sifting "fact" from "fiction" difficult, but because it actively challenged the validity of such a sharp conceptual division in the first place. ${ }^{109}$

It is in this context, I believe, that the enigma of Salih's age is to be considered most productively as well. Namely, at the outset of Pričanje I, the singer states that he is 85 years old, but in the heading to the transcript of Ženidba Đerđelez Alije ("The Wedding of Đerđelez Alija," PN 277) which he had recited earlier in the year, Nikola wrote that Salih was 70 . To complicate matters further, Matija Murko (1951:94) proposes that the singer's age was 63 when they met in 1930 (which would have made him 67 at the time of the interviews), while also noting that Alois Schmaus reckoned Salih was born around the year 1866 (making him 68 in 1934). While it is not unusual for a person of that time and place not to have known the exact year of his/her birth, it is interesting that Salih here opted for more years rather than less. In a culture that, as said before, generally privileges men in possession of their full physical and mental powers, there is only one cultural niche where great age is an asset, and that is in the custodianship of traditional loreSalih's domain. Again, 85 is a significant and precise number in the context of the singer's selfperception and self-performance, as it puts him on par with his most esteemed predecessor Ćor Huso, who, Salih claims (PN 655, III:55, R 950), was around 80 himself when he taught him some of his songs.

On occasion, it is not what Salih specifically says or does, but the sheer force of his performative habits that works to unnerve the two young men. Thus, for instance, at one point in Pričanje I after his recitation has been interrupted by the noise of squeaking doors, the murmur of intruder(s), and the interviewers' frequent requests to speak louder, Salih, upon yet another Malo jače ("A little louder!") from Parry, all of a sudden bursts into a song, apparently forgetting about the prohibition of singing during the mourning of King Aleksandar I. Under the strain of reciting (not his usual way of delivery) and being interrupted - and by this time in the day also being rather worn out-Salih here does nothing more than merely revert to his natural way of performing. The effect on Nikola and Parry, however, is mild panic, as the two men, probably worried that this might land them in trouble with the authorities, both scuttle to hush the singer (PN 652, I:144, R 898: 1:42-1:51): MP: Nemoj pjevat, pričaj (“Don’t sing, talk”); N: Nemoj

109 Consider, for example, Lord's explanation of Đemail Zogić's conception of exactness/truthfulness (2000[1960]:28). 
pjevat nego pričaj ("Don't sing but talk"); MP: Pričaj ("Talk"). ${ }^{110}$ In this case, it is not that Salih acts on purpose so as to get back at the collector and the interpreter for putting these additional strains on him, but it is as though his very world of traditional performance is rebelling on his behalf against the discipline of the imposed setup.

\section{Subverting the Request and Taking Charge}

In addition to the traditional cognitive frameworks that enable Salih to counter his interviewers' epistemic impositions, other rather effective means of resistance are his evasion of Nikola's questions - often using the interviewers' very appetite for stories to help him change the subject - and his pretending to give way to their request, only to subvert it in the end. For example, anxious to tell the story about the rescue of two sultanas from the town/empire of Đirit, Salih brushes aside Nikola's hopes of hearing some stories about the famous Albanian hero Skenderbeg that his mention of a place called Skenderija inadvertently inspired (PN 656, IV:35, R 982): Valahi nešto sam čuo za Skender bega, teke tu je jedna carevina bila. Đirit je bila dvadeset $i$ sedam godina ("By Allah, I did hear something about Skenderbeg, but there was an empire there. Đirit was there for 27 years"). Not only does Salih turn the focus back onto Đirit to suit his inclinations, but he also adds a narrative detail ("for 27 years") to inspire curiosity in his listeners and thus make them forget or at least abandon their previous pursuits. Later, upon finishing a story about an Albanian outlaw, he sees that Nikola has some more questions, but instead of answering them, Salih quickly offers another tale in exchange (PN 656, IV:68, R 992): $\mathrm{N}$ : Jeli to davno bilo? ("Was that long ago?"); S: Pa da ti prićam još jednu priću? ("Well, shall I tell you one more story?"). And sure enough, such an offer proves too irresistible to pass up for the sake of some minor detail from the previous tale.

However, the most spectacular example of subversion must be Salih's way of dealing with Nikola's repeated requests for a song in which the Serbs win the day. In itself, this kind of request would not have been unusual as it was common knowledge that some of the more traveled singers often had two repertoires in order to cater to the tastes of both Christian and Muslim audiences, the most famous example being that of the nineteenth-century blind singer Filip Višnjić (Nedić 1990:43), whose portrait serves as the logo for this very journal. Murko is also familiar with the phenomenon and notes the sentiments of the frequenters of Muslim coffeehouses as follows (1951:42): Samo da je dobar junak, tu se sluša bez razlike ("If only he [the main character] is a good hero, [the song] will be listened to with no difference [as to the hero/ singer being Muslim or Christian]"). In this context Salih himself is similarly eager to tell of his (already mentioned) encounter with the Serbian sergeant Uroš who granted him the liberty to cut down anyone he liked in his songs, and it is also a matter of great pride for him to claim that he would not kill off a Serbian hero in a song just because he was a Serb (PN 655, III:5, R 939). Thus the question that Nikola poses to the singer during the very first interview (PN 652, I:34, R 867): Znaš li ti srpskije pjesama? ("Do you know [any] Serbian songs?”) is neither offensive nor indelicate, even if Salih himself repeatedly fought against the Serbs - in the Balkan Wars, in World War I, and in any large or small local skirmish imaginable. However, what does imbue the

\footnotetext{
${ }^{110}$ Nikola only transcribes his own intervention, but Parry can also be heard both before and after it.
} 
question with some tension, despite Nikola's characteristically cheerful manner, is the fact that he persisted in posing it even though he received a negative answer the first time he asked (PN 652, I:34, R 867): Vala ja srpski neznam, sem na ova jezik ("Well, I don't know any Serbian [songs] apart from [those] in that language"). Seeing that the young man would not get off his hobbyhorse so easily, Salih will in Pričanje III finally "admit" that he knows one such song, and he will take quite some time to recite a long poem about two Serbian captains who are not-sobad heroes until the end when they still prove to be no match for the dashing Muslim hero Mujo, who kills them and carries off the wife of one of the captains to marry her himself (PN 655, III: 49-50, R 949: 1:17-2: 03):

N: Kako to? Ti si rekao da ćeš pjevat pravoslavnu pjesmu, da ćeš pričat a ti si već sada da su turci pobjedili. Kako to Bogati?

S [through laughter]: Bogami, ja onako mi dade uz riječ, a neznam ... [All chuckle].

MP: Rekao si da će bit pravoslavna pjesma.

N [repeating Parry's remark louder]: Rekao si da će bit pravoslavna pjesma.

S: Vala pravoslavna jes, ama teke, ja zar zanosim na turski, a oni ovo pevaju.

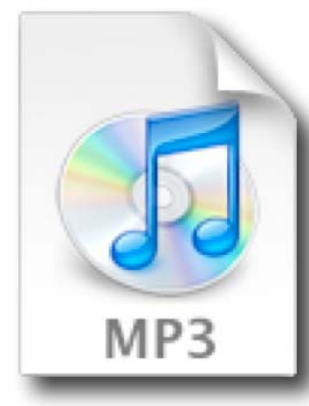

PN 655, III:49-50, R 949: 1:17-2: 03

$\cdots$

$\mathrm{N}$ : A znaš li ti koju drugu srpsku pjesmu?

$\mathrm{S}:$ A pa ima.

$\mathrm{N}$ : Ma đe srbin pobijedio turčina? Znaš li?

S: Vala, pa znam to nekoliko.

N: E hajde jednu da mi kažeš, koju? Koju to hoćeš?

S: A da ope će platit Srbin najzadnje.

N: How's that? You said you were going to sing an Orthodox song, that you are going to tell, but you now [made it so] that the Turks won! How's that, by God?

S [through laughter]: By God, that's how the words came to me, and I don't know . . . [All chuckle].

MP: You said it was going to be an Orthodox song.

N [repeating Parry's remark louder]: You said it was going to be an Orthodox song.

S: Well it is Orthodox, but I lean towards the Turkish [point of view?], and they sing this.

$\cdots$

N: But do you know some other Serbian song?

$\mathrm{S}: \mathrm{Ah}$, well there are some.

N: But where a Serb won against a Turk? Do you know [any]?

S: Well, I know a few.

$\mathrm{N}$ : Eh, come on, tell me one! Which? Which one do you want?

S: Well, yes, but the Serb will pay in the end again. 
Not even this outcome will deter Nikola, and a little later, as the conversation turns back to Ćor Huso, he asks whether the legendary singer knew any Serbian songs. Salih initially answers that (like himself) Ćor Huso only sang in Serbian/Bosnian, but when Nikola repeats the question one more time, the singer says that indeed Ćor Huso sang about a certain Stojan Čupić (the nineteenth-century Serbian chieftain and one of the leaders of the First Serbian Uprising). Excited but perhaps also suspecting that this roundabout way of finally coaxing the singer into reciting an "Orthodox song" is still too good to be true, Nikola asks cautiously (PN 655, III:58, R 951): Jeli fina pjesma? (“Is it a fine song?"). The singer's preemptive answer $A$ da ono tako je bilo znaš ("Well, yes, that's how it happened, you know") already hints at how the song will finish, and sure enough, Čupić ends up dead, with the final laudatory remarks devoted to the local Adempašić family of Novi Pazar. Here Nikola finally, if cheerfully, admits defeat by way of teasing the singer (PN 655, III:61, R 952: 1:55-2:04): N: Beli se radi tu da je neki srbin pobjedio dok ti ne pjevaš? ("Could it be that that song is about some Serb winning, just as long as you are not singing [it]?”); S: Bogami . . . (“By God . ..”[all chuckle]). Even though, as discussed before, Nikola will continue to tease and contest the singer over the issue of whether the Christian or Muslim heroes were better warriors, he does not, however, ask him again to recite an "Orthodox song."

Unable to evade an imposed task completely, the singer at least sometimes manages to dictate the terms under which he will go about performing it. Thus when, after the initial confusion as to what is expected of him, Salih finally assents to improvise a poem about their encounter and (by then) a six-days-long collection of poetry, he proceeds in the typical manner of an epic singer faced with composing a song about a new event ${ }^{111}$ (PN 655, III:106-07, R 966: $0: 13-1: 12)$ :

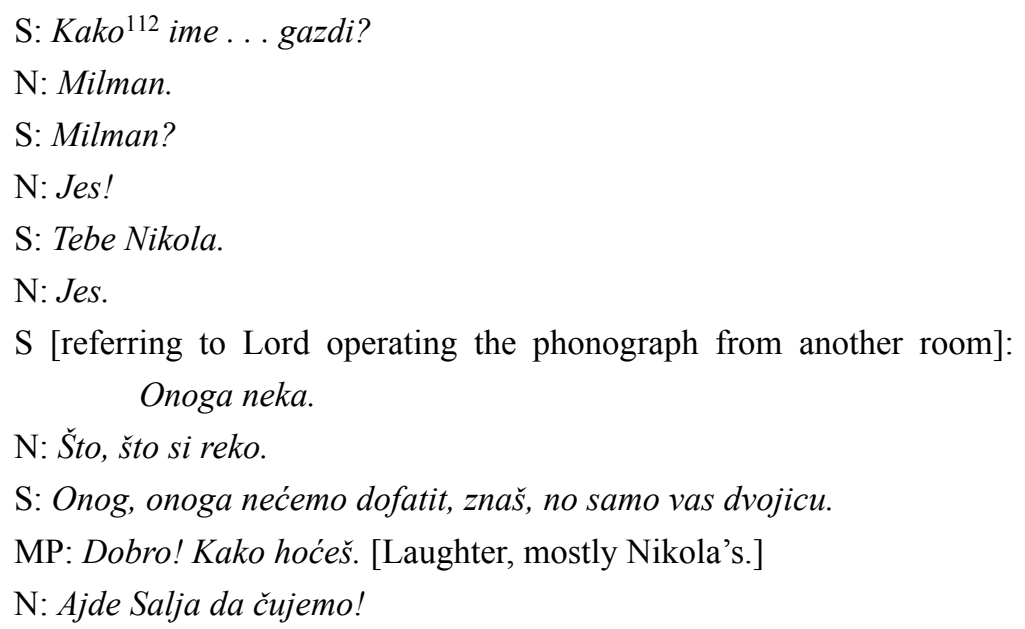

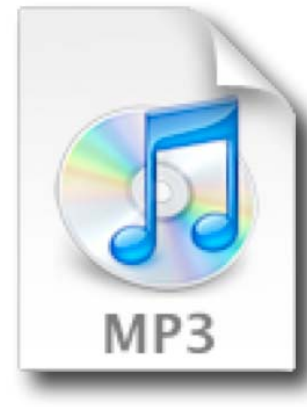

PN 655, III:106-07, R 966: 0:13-1:12

${ }^{111}$ As early as the nineteenth century, the singer Filip Višnjić offered useful insights in this regard. He said that after a battle he would ask the returning soldiers about who led the forces, where and against whom they fought, who was killed, and so on (Nedić 1990:52). Salih himself offers a similar list of such key narrative points in Pričanje IV (32, R 982).

${ }^{112}$ Nikola here inserts the verb $b i$, but the singer cannot be heard saying it. 
S [quietly, to himself]: E da vidim u koji dan smo poćelji . . u ponedeljak. ... ${ }^{113}$

$\mathrm{N}$ : Ma lijepo ko za gusle znaš.

$\mathrm{S}$ [quietly]: A da vala....

$\mathrm{N}$ : Počeli smo radit ovđe u poneđeljak, a danas je subota.

$\mathrm{S}$ [pensively]: Jes ... demek radilji smo cijo dan do, do noći.

N: Jes.

$\mathrm{S}$ [more confidently]: U svaki dan cijo dan do noći, radilji smo ...

$\mathrm{N}:$ Jes.

S: I tako, [Parry interrupts] . . i tako smo pjesmu. ...114

MP: Glasnije! ${ }^{115}$

$\mathrm{S}: A$ ?

$\mathrm{N}$ : Glasnije pričaj!

S: Glasnije ću pričat, teke sad dok... [Recitation follows after a pause of seven seconds].

S: What is the name ... of the boss?

$\mathrm{N}$ : Milman.

S: Milman?

$\mathrm{N}$ : Yes.

S: Yours is Nikola.

$\mathrm{N}$ : Yes.

S: [referring to Lord operating the phonograph from the next room]: That one, let him be.

$\mathrm{N}$ : What, what did you say?

S: The other, the other one, we won't put him in [the song], you know, but only you two.

MP: All right, as you please. [Laughter, mostly Nikola's.]

$\mathrm{N}$ : C'mon, Salja, let's hear it!

S: [quietly, to himself]: Well, let me see, what day did we start . . . on Monday. ...

$\mathrm{N}$ : But nicely, as though for the gusle, you know. ${ }^{116}$

$\mathrm{S}$ [quietly]: Ah, yes, of course....

$\mathrm{N}$ : We started working here on Monday, and today is Saturday.

$\mathrm{S}$ [pensively]: Yes ... indeed, we worked the whole day till night.

N. Yes.

$\mathrm{S}$ [more confidently]: Every day, the whole day until the night we worked. ...

$\mathrm{N}$ : Yes.

S: And so, [Parry interrupts] . . and so we did the song. ...

MP: Louder!

S: Huh?

${ }^{113}$ The last two words do not appear in the transcript.

${ }^{114}$ Nikola transcribes this last bit as: I tako ćemo pjesmu pjevat (“And thus will sing the song”).

115 Nikola skips Parry's and his own requests to the singer to speak louder, signaling the ellipsis with a longish continuous line.

${ }^{116}$ In his translation of this dialogue Lord (2000[1960]:287) mistakenly ascribes this sentence to Parry. 


\section{N: Speak louder! \\ S: I will speak louder, but now while ... [Recitation follows after a pause of seven seconds].}

As the singer gathers (or rather rehearses) the information about the participants, event, and details worth mentioning, he is already trying things out, placing the facts playfully into formulaic decasyllabic lines ("we worked the whole day until night," "every day till night we worked"), repeating them as though to ensure they are correct, making choices ("we won't put him in"), mumbling pensively, warding off with various fillers and elliptical statements the two men's premature prompts and demands to speak more loudly-in other words, he is biding his time and stalling (in hindsight, his initial "confusion" about Nikola's request may have been a part of this delaying tactic as well). Thus we see the singer taking charge, applying his expertise, exercising his liberty, managing his audience's impatience, and making creative decisions, even if the resulting poem is but an adequate response to an inadequate request.

At least in the context of the South Slavic oral epic of the time, Lord rightly explains (2000 [1960]:286) that "collectors and collecting are not inspiring nor proper subjects for epic!" Jeff Opland (1988:353), however, is not entirely convinced and wryly suggests that Lord's consignment of such material to "footnotes and appendices" may have had something to do with the fact that, in comparison with Parry, "Lord himself receives short shrift in these songs." Opland then proceeds to cite this same part of Pričanje III in which Salih decides to exclude Lord from his song as a colorful background for his own story of Lord's 1985 visit to South Africa, at which time this distinguished scholar "graduated from his position 'in the next room at the recording machine"" (354) and thus managed to inspire a Xhosa praise poem. What entirely escapes Opland's attention in this process is that Salih's song actually excluded not only the student but "Professor Milman Parry the glorious""117 (353) as well, the "boss" himself. The central characters are in fact the singer and the scribe, and in that order (PN 655, III:107, R 966): Ja i Nikola pesme iskazali / Ja kazao Nikola pisao ("I and Nikola recited songs, / I told them, Nikola wrote them"). Parry, the very person who instigated the collection and paid for all the tea, coffee, tobacco, and daily allowances, is only possibly subsumed under the collective pronoun, which may have, after all, included Lord as well (PN 655, III:107, R 966): I mene su pošteno platili ("And they paid me fairly"). ${ }^{118}$ In this way, Salih's poem, which fails as an epic but amply fulfills the aims of Parry's experiment by shedding light on both the improvisational techniques of oral singers and the importance of adequate subject matter, also bears witness to the singer's self-assertion and his resistance to the imposed experimental setup.

\section{Incomprehensibility for Incomprehensibility, a Joke for a Joke}

When faced with an uncommon task, the purpose of which is not entirely clear to him, the singer sometimes responds by being unclear and incomprehensible himself. For instance, as

\footnotetext{
117 Opland here refers to the dedication portion of the song composed in Parry's honor in 1933 by a literate oral singer, Milovan Vojičić.

118 Lord translates this sentence as (2000[1960]:287): “And they paid me honorably," which better accords with the attempted genre but is not as close to the original meaning as "fairly" is.
} 
mentioned earlier, the second interview was particularly cognitively taxing, as Salih was continually asked to translate songs from Albanian into Bosnian/Serbian and vice versa. Although both actions felt counterintuitive, Salih was, with minor effort, able to perform the first, which also made more sense since his interviewers could only understand Bosnian/Serbian. However, he found translating (or rather recomposing) a song ${ }^{119}$ from Bosnian into Albanian extremely hard, and was possibly also perplexed about what use such translations could be to the two men, neither of whom spoke Albanian. Although John Kolsti (1990:61) convincingly argues that the main difficulty with this task was that Salih understood he was supposed to translate "a ten-syllable line in Serbo-Croatian into an eight-syllable Albanian line," I would suggest that the fact that his interviewers understood no Albanian also played an important role. As already discussed, a listener is a constitutive part of a speaker's voice. It is perhaps no wonder then that, when asked to recite in a language no one present would understand, Salih struggles to find his "Albanian" voice. And so, just as Parry and Nikola are in no hurry to explain the purpose of such a request, the singer makes no great effort to make the explanation of his difficulty any clearer than the following (PN 654, II:14, R 910-11): Ono povlažne su bosanske; znaš ne more da se okreće arnautska. Arnautska je pokraća jezik, a bosanska jok no poduža. I sličnije je bosanski no arnautski. ("Well, Bosnian [songs] are a bit wetter [better flowing? smoother?], you know, it [they?] can't be turned into Albanian. Albanian is a shortish language [poetic language? verse?], whereas Bosnian is not, but is rather longish. And Bosnian is more similar [pliable?] than Albanian.") ${ }^{120}$ When, shortly after, the matter is raised again, Salih offers the consistent and confident explanation (PN 654, II:15-16, R 910-11): one vlažne su, povlažnije su. Poslićnije dolazu riječi ("they [Bosnian songs] are wet, they are wetter [better flowing?]. The words come out more similarly [fit together better?]"). As the issue continues to crop up in the subsequent pričanja (e. g., PN 655, III:79-89, 103-04, R 957-60, 965; PN 658, V:63-64, R 1019) and Salih's vocabulary - although iterative-becomes clearer as it is applied in these slightly different contexts, it seems that what the singer means is that he finds it easier to lengthen the shorter Albanian meter as he translates a song into Bosnian, rather than to adequately shorten the Bosnian longer verse (cf. Kolsti 1990:61). In addition, as I tried to suggest in the square brackets above, to Salih Bosnian songs (which he generally prefers to his native Albanian) are "better flowing" and the words (that is, traditional idiomatic units) somehow tend to "fit" better or come along more easily upon translation from the Albanian into Bosnian than when he attempts the opposite. As I myself commit epistemic violence by presuming to speak for the singer here, I

119 See Kolsti 1990.

${ }^{120}$ In an attempt to provide a readable translation of this passage, Kolsti (1990:60) invests it with a clarity and coherence that it does not have. He also only concentrates upon Salih's comments on the difference in length of the respective "languages" (verses), which indeed supports his claim regarding the singer's difficulty in casting decasyllabic verses as octosyllabic. However, Kolsti does not give attention to the other part of Salih's explanation - that Bosnian language is "wetter" - which the singer always repeats in conjunction with the comment on the length of the two "languages." In fact, Kolsti does not include this concern in his translation at all. Of course, this omission is probably due to the extreme difficulty of understanding what precisely Salih meant; but its exclusion (for whatever reason) makes Kolsti's explanation of Salih's difficulty appear more definitive than it might otherwise have been. Furthermore, no explanation is given as to why I sličnije je bosanski no arnautski is translated as: "And Bosnian is more regular than Albanian." Literally, sličnije means "more similar." If a wider perspective is taken, the root of this word can be understood to connote harmony (as in slik, "rhyme"), something that is suitable or befitting. Regularity, on the other hand, is only one possible aspect of harmony. 
cannot but notice that in order to arrive at even this meager translation of his "incomprehensible" statements, the singer's entrenched position has forced me in turn to undergo a violent cognitive strain. I imagine (and in so doing commit yet another violent act) that the effect of Salih's explanation on Parry and Nikola could not have been much different.

For a last example of Salih's “counter-strikes," I will briefly return to the power of humor since - even though it happens rarely - the singer himself occasionally jokes with the two young men as well. For instance, when, after a long and tiring day the indefatigable Parry asks the singer (PN 656, IV:104, R 1000): Šta će bit danas ("What [else] will be today?"), Salih promptly responds: Ono veljiko vala malo ne ("That big [thing], by God, not the small"), upon which everyone bursts into laughter. Not knowing the exact context, it is very difficult to guess the precise meaning of Salih's ellipsis. However, the end of Pričanje $V$ suggests a possible answer. There Salih refers to something in his possession (something that Parry seems to have just given him) as ovo veljiko ("this big [thing];" PN 658, V:141-42, 1041), which seems to have been a fifty-dinar coin/note, or petica ("a fiver") — his daily allowance. He then goes on to distinguish it from a smaller unit, a ćetvor ("a quarter"? "25 dinars"? "40 dinars"?). If, therefore, Parry and Nikola knew that the "big thing" for the singer was the larger rather than the smaller amount within the range they used to pay him, it becomes clear why they instantaneously burst into laughter. Salih effectively subverts Parry's roundabout way of asking that they do some more work that day by taking the question quite literally and suggesting that it is the time of day for them to pay up - in other words, that he is done for the day. Regardless of whether my guess is right, it seems that Salih not only successfully managed to joke back, but he also won his deserved break. ${ }^{121}$

Similarly, at another point during Pričanje IV (it seems Salih was in a particularly comical mood that day!), by way of explaining what details he would need to know in order to compose a song about an event worthy of an epic, the singer takes Nikola as a hypothetical hero of such a story (PN 656, IV:32, R 982: 0:17-0:33): Otišao je . . Nikola. Otišao je u Bosnu $i$ ućinio si neakvu ja štetu ja . . . ("He went . . . Nikola. He went to Bosnia, and you did some damage there, or ..."). Nikola here cannot resist the urge to tease the singer a little, so he interrupts: Da, recimo posjeko trista turaka, recimo ("Yes, for example, [he] cut down three hundred Turks, for example"), thus effectively putting into Salih's mouth a story in which his usual heroes become defeated villains (and dispensable extras at that!). Unshaken, the singer promptly fires: I posjeko jednoga, dosta bi bilo ("And [he] cut down even one, that would have been enough"). Again, laughter is heard here (most likely Nikola's own), as the witty mediator is himself outwitted. What makes this joke particularly clever is that, while Salih's sentence appears merely to state a simple truth, that even a victory over a single enemy (for instance, in a duel) is perfectly song-worthy, he at the same time very clearly suggests that for "heroes" such as Nikola cutting down even one "Turk" would be enough of a feat.

${ }^{121}$ I am grateful to Scott Garner for suggesting an alternative possibility - that Salih is here lightly mocking Parry and Nikola who frequently asked for longer rather than shorter songs. I must also add that, before encountering the above dialogue from Pričanje $V$, and purely based on the "inside" knowledge of the culture (which, of course, can sometimes lead one to spectacularly wrong conclusions!), my first impulse was to take Salih's remark as a bit of toilet humor. 


\section{Claiming the Spoils of the Epistemic Clashes}

Just as fascinating as Salih's self-assertion in terms of resistance is his equal readiness to lay claim to the imposed proceedings and adopt them as his own, as well as to appropriate instantly the products of the requests against which he had initially struggled but was unable to evade. For example, even though he was illiterate and Nikola was the sole scribe present, Salih seems to consider this imbalance a technicality and refers to the writing as a common undertaking (e. g., PN 656, IV:38, 104, R 983, 1001): Pa ćemo pisat, iz kraja ("Then we will write, from the beginning"); Pa imamo da pišemo ("Then we have [things] to write"). Moreover, his occasional slip of the tongue reveals that he may have perceived himself as the one writingin effect if not in fact (PN 659, VI:119, R 1072-73): ovo nebi pisao ni jedan nebi ti mogo kazat ("no one could write this [for you] ... [he] couldn't tell you this"). Although Salih immediately corrects himself here, another similar instance suggests this to be more than just a lapse. In Pričanje $V$ he refers to a book of stories in which (PN 658, V:138, R 1040): bijo sam upisao nekoljiko prići ("I had written down a few stories"), only later implying that these were written down from him rather than by him. The singer thus sees and presents himself as the one with whom the writing originates, even if he is not the one holding the pen in his hand.

As discussed earlier, Salih's experience of rapidly translating songs from Albanian into Bosnian/Serbian (and especially vice versa) was particularly grueling. However, once he finds himself on the other side of the task, he is clearly proud, suggesting that nothing is beyond him, given a bit of time (PN 654, II:33, R): N: Vidiš, a da nemoreš druge preves ("You see, and [to think] that you can't translate others [songs] ...") S: Pa ja znaš, dok bi misljio đavola .. . (Well, I, you know . . . till I would [take some time to] think [about] the devil [i.e., the song?] . . " ). ${ }^{122}$ Consequently, the singer does not always experience the tasks Parry sets as simply a burden, but also as a challenge, even if only in retrospect. For instance, in Pričanje III, as he enjoys Parry's praise for a successful translation, the singer takes similar pleasure in dramatizing the process that led him to this achievement and in (perhaps inadvertently) casting himself in the role of a tormented genius (75, R 956): Ja svu noć đavola dok sedim. Sve mislim kako koja more da se prevede, ovako da je slićno, ovako da je .. . ("All night I [thought of] the devil, as I was sitting. All the time I'm thinking how could this or that one [the song] be translated: like this it would accord well, like that it would ..." ). The collector's experiments also reveal to Salih the unexplored aspects of his practice and offer new insights into his creative abilities, which the singer finds gratifying. Thus, even though his own habit is to sing rather than to recite the songs, when asked in Pričanje $V$ whether the sung or recited songs are better, the singer gives precedence to the latter. Even if this stated preference were nothing but an attempt to please his interviewers and tell them what he thinks they would like to hear, the act would have been empowering, reinstating the singer's control over his audience. As it is, Salih's long and ardent answer seems to express genuine excitement about this novel (at least for him) kind of delivery (PN 658, V:67, R 1020): Bolje kazivane. Što ove, što se peva, ove što se pevaju u guslji, u ono

122 The sentence is very elliptical, and thus one cannot hope for an incontestable explanation of the singer's meaning. Nevertheless, what seems most likely to me is that Salih is here agreeing with Nikola regarding his ability to translate those "other songs" as well, provided only that he is given enough time to think the "devil" (that is, the task/song/translation) over, rather than doing it on the fly as the two men requested from him earlier. 
hitaš . . ja će preskoćit, ja će preturit, ja će poturit, a ovako iskazane, ono nema no ide ka ono, ka na ćitanju. Tak, tak, tak, tak, sve redom ("The recited [songs] are better. These that, these that are sang to gusle, during those you hurry ... one will either skip [things], or jumble [them] up, or sneak [them] in, but recited this way, there is none of that, but [the whole thing] goes as if at a reading: tack, tack, tack, tack, all in order"123). Thus, rather than merely being a passive "subject" of scholarly experimentation, Salih himself derives from the experience some professional satisfaction and personal sense of achievement.

Salih Ugljanin, an 85-year-old ${ }^{124}$ man who had gone from riches to rags but was still making his living by relying on his cleverness (pamećom; PN 652, I:16, R 862), was one who had lived through several wars and also suffered loss and displacement. He was someone who, until his thirtieth year, had exclusively sung in his native Albanian, but he was so curious, so intellectually and spiritually agile, that by his thirty-fifth year he had mastered another language and another traditional epic idiom (that of the Bosnian Muslims). He was a singer who was proud of his skill and knew its worth for collectors; ${ }^{125}$ he was also a performer who had encountered enough ethnically and religiously diverse audiences to learn to have an answer to any question (even when he did not have it). Such a man could hardly have let himself become a passive conduit of others' bidding, a mere facilitator of their self-fulfillment.

As we have seen, throughout the interviews Salih responds with a series of intricate strategies by which he evades or resists various pressures from his interviewers and sometimes takes control over a situation that has become uncomfortable. Whether these are conscious or intuitive strategies is hard to say (and it is even harder to draw a rigorous distinction between the two), but they are rather effective in terms of his self-assertion and disruption of the imposed hierarchy in which his place is decidedly lower. Moreover, Salih readily lays claim to the fruits of the epistemic clashes in which he engages with the collector and the interpreter. It is in this space, I have argued, where the "dominant" is thrown off balance and the "subaltern" finds personal stake in the imposed proceedings, where a dialogue has in fact taken place and mutual learning occurred.

\section{Violence and Splendor of Epistemic Harvests}

The Pričanja with Salih Ugljanin call for a more optimistic revision of the possibility of dialogue between the dominant and the subaltern. What I believe they vividly (and at times poignantly) remind us is that epistemic violence is constitutive of any and all relations with the other, and that as such it is necessarily a two-way economy. Rather than lamenting the very

123 Kazivati redom ("to tell in order") seems to be one of the main aesthetic principles in composition of South Slavic oral epic, and its importance is particularly emphasized by the famous nineteenth-century Serbian collector of oral lore, Vuk Stefanović Karadžić. For a more detailed discussion see Milošević Đorđević 2002. Coincidentally, David Elmer's (2010) already convincing comparison of South Slavic kita and Homeric kosmos would have been made even stronger had it featured a discussion of this traditional principle.

${ }^{124}$ Salih's exact age has been discussed above.

${ }^{125}$ As mentioned earlier, Salih had already sung for Matija Murko and would later sing for Alois Schmaus as well. 
condition of possibly ever encountering the other, we must rather be forever vigilant against forgetting the violence that in each case brought to us the fruits of our epistemic harvests. If Lord's Singer of Tales is one such splendid product guilty of neglect and this forgetting, the Pričanja - with Salih Ugljanin as the record of both the "harvest" and the "fruit" in its own right - accuse their authors of epistemic violence and simultaneously exonerate them because none of the violence is forgotten. Published online, available for inspection, and open to endless scrutiny, these interviews, with their relentless complexity, are enabled to fight any simple appropriation of the other: that of Parry and Nikola regarding the singer, or mine regarding all of them.

Finally, as an afterthought and a brighter counterweight to some of the more somber thoughts on the subtle and ongoing power struggles at play in the Pričanja, I would like to stress that we only ever manage to see our differences, our "othernesses," because they are framed by the commonalities that define us - among other things as (Swift 1983:62) "the story-telling animal[s]." Indeed, there are such moments in the Pričanja when the balance of power is shifted away from the collector, the mediator, and the storyteller alike onto the story and the performance itself - moments when the captivated collector forgets about the purposes of his research trip and about the hypotheses he might be able to prove or form; when the mediator, eager to hear the end of a funny story, cannot compose himself enough to stifle a juicy swear word of approval, begging the storyteller to continue; when, infected by his audience's laughter, the storyteller falters at his post and cannot go on because he must hold his own splitting sides. And then, when the story is finally told in full, no one rushes to move on, to use up the time prudently and efficiently, to collect more, to prompt more, or to command more attention, but instead they all want to use the fancy technology to hear the story again and repeat the experience; for a moment, these three very different men indeed become a true small community, hard won by those days of intense interaction and mutual probing and violence (PN 655, III: 99-100, R 963: 2:30 to R 964: 0:37):

N [fighting his own and general laughter]: Pričaj još Bogati jebem!

$\mathrm{S}$ [himself laughing]: Ma neda mi smijeh.

[Salih continues, and at times also enacts his story, interrupted only by common laughter. ... .]

$\mathrm{N}$ [coughing and laughing along with the others]: Jeli to istina bila čiča?

$\mathrm{S}$ : Istina istinska, ovo ti pričam. ${ }^{126}$

$\mathrm{N}$ [laughing and swearing approvingly]: I nije išo po drugu jeli?

$\mathrm{S}$ [fighting his own laughter]: Bože saćuvaj! [Parry here contributes an inaudible but obviously jolly remark] . . . Tako mi Boga . . . ne znam. . . . 127

N [interjecting, through laughter]: Ajde Bogavam da čujemo ovu ploču šta je bilo? [All burst out laughing.]

\footnotetext{
${ }^{126}$ Nikola here instead transcribes: Istina istinska ovo ti je bila ("The truest truth this was").

${ }^{127}$ The last two words are not transcribed.
} 


\section{S: Haj Bogami . . Ovo nema niđe ni u Auropu. ${ }^{128}$}

$\mathrm{N}$ [fighting his own and general laughter]: Tell more, for fuck's sake! ${ }^{129}$

$\mathrm{S}$ [himself laughing]: The laughter is not letting me.

[Salih continues, and at times also enacts his story, interrupted only by common laughter....]

$\mathrm{N}$ [coughing and laughing along with the others]: Was that a true story, old man?

S: The truest truth, this, I tell you.

$\mathrm{N}$ [laughing and swearing approvingly]: And he didn't go for a second one [wife], ha?

$\mathrm{S}$ [fighting his own laughter]: God forbid! [Parry here contributes an inaudible but obviously jolly remark] ... I swear to God ... I don't know. ... .

$\mathrm{N}$ [interjecting, through laughter]: C'mon, by God, let's hear this record [again], what happened. [All burst out laughing.]

S: Let's, by God ... There's nothing like this anywhere, not even in Europe!

\section{Centre for Medieval Studies} University of Bergen

\section{References}

Alexander and Elias-Bursać 2006 Ronelle Alexander and Ellen Elias-Bursać. Bosnian, Croatian, Serbian: A Textbook with Exercises and Basic Grammar. Madison: University of Wisconsin Press.

Clifford and Marcus 2010

Climenhaga 2009

Deretić 2000

Derrida 1997

Đorđević 2005
James Clifford and George E. Marcus, eds. Writing Culture: The Poetics and Politics of Ethnography. Berkeley: University of California Press.

Royd Climenhaga. Pina Bausch. London: Routledge.

Jovan Deretić. Srpska narodna epika. Beograd: Filip Višnjić.

Jacques Derrida. Of Grammatology. Trans. by Gayatri Chakravorty Spivak. Corrected ed. Baltimore: Johns Hopkins University Press.

Smiljana Đorđević. "Jedan trenutak savremenog guslanja—guslar Slobodan Gligorijević." Liceum, 9:139-66.

128 Nikola omits the conjunction " $\mathrm{u}$ " in the transcription and inserts the noun "Auropa" (Europe) in the "correct" locative case (Auropi), whereas the singer gives it in the dative (Auropu).

${ }^{129}$ Literally: "Tell some more, may I fuck your God!" Although in English this swear word, directed at the singer, sounds supremely offensive (especially when taking Nikola's and Salih's religious differences into account), this is in fact one of the mildest Balkan swear words and is here employed in just the opposite spirit - to emphasize Nikola's approval of Salih's story. 
Đurić 1977

Elmer 2010

Finnegan 1992

Foley 1991

Foley 1998

Foley 2004

Foley 2005

Foley 2007

Grđic Bjelokosić 1902

hooks 1992

Jakobson 1954

Jakobson and Bogatyrev 1971[1929]

Karadžić 1870
Vojislav Đurić, ed. Antologija narodnih pripovedaka. Beograd: Srpska književna zadruga.

David F. Elmer. "Kita and Kosmos: The Poetics of Ornamentation in Bosniac and Homeric Epic.” Journal of American Folklore, 123:276-303.

Ruth Finnegan. Oral Poetry: Its Nature, Significance, and Social Context. 2nd ed. Bloomington: Indiana University Press.

John Miles Foley. Immanent Art: From Structure to Meaning in Traditional Oral Epic. Bloomington: Indiana University Press. "Individual Poet and Epic Tradition: Homer as Legendary Singer." Arethusa, 31:149-78. . "Nikola Vujnović's Resinging." In The Wedding of Mustaybey's Son Bećirbey as Performed by Halil Bajgorić. Ed. and trans. by John Miles Foley. Folklore Fellows Communications, 283. Helsinki: Academic Scientiarum Fennica. pp. 145-91. eEdition at http://oraltradition.org/zbm/resinging.

. "From Oral Performance to Paper-Text to Cyber Edition." Oral Tradition, 20:233-63. http://journal.oraltradition.org/issues/20ii/foley

_. "Reading' Homer through Oral Tradition." College Literature, 34:1-28.

Luka Grđic Bjelokosić, ed. Stotina šaljivih priča. Iz srpskog narodnog života u Herceg-Bosni. Mostar: Paher i Kisić.

bell hooks. "marginality as site of resistance." In Out There: Marginalization and Contemporary Cultures. Edited by Russell Ferguson, Martha Gever, Trinh T. Minh-ha, and Cornel West. New York and Cambridge, MA: The New Museum of Contemporary Art and the MIT Press. pp. 341-43.

Roman Jakobson. “Preface.” In SCHS I:xi-xii.

Roman Jakobson and Petr Bogatyrev. "On the Boundary between the Studies of Folklore and Literature." In Readings in Russian Poetics: Formalist and Structuralist Views. Ed. by Ladislav Matejka and Krystyna Pomorska. Cambridge, MA: MIT Press. pp. 91-93

Vuk Stefanović Karadžić, ed. Srpske narodne pripovjetke. Drugo umnoženo izdanje. Vienna. 
Kay 1995

Kilibarda 1972

Kolsti 1990

Lord 1954

Lord 2000[1960]

Marker 2003

Milošević Đorđević 2002

MPCOL

Murko 1932-33

Murko 1933

Murko 1951

Murko 1990

Nedić 1990

Opland 1988
Matthew W. Kay. The Index of the Milman Parry Collection 1933-1935: Heroic Songs, Conversations and Stories: New York: Garland.

Novak Kilibarda. "Specifičnost crnogorske narodne epike." In Poezija i istorija u narodnoj književnosti. Ed. by Novak Kilibarda. Beograd: Slovo ljubve. pp. 85-103.

John Kolsti. The Bilingual Singer: A Study in Albanian and Serbo-Croatian Oral Epic Traditions. New York: Garland.

Albert B. Lord. “General Introduction.” In SCHS I:3-20.

The Singer of Tales. Harvard Studies in Comparative Literature, 24. New ed. Cambridge, MA: Harvard University Press.

Michael Marker. "Indigenous Voice, Community, and Epistemic Violence: The Ethnographer's 'Interests' and What 'Interests' the Ethnographer." Qualitative Studies in Education, 16:361-75.

Nada Milošević Đorđević. Kazivati redom: Prilozi proučavanju Vukove poetike usmenog stvaranja. Beograd: Rad, KPZ Srbije.

"Milman Parry Collection of Oral Literature On-Line." http:// chs119.chs.harvard.edu/mpc/index.html

Matija Murko. “Zpěvačky epických písní v Dalmácii.” Československojihoslovanská revue, 3:297-301. . "Nouvelles observations sur l'état actuel de la poésie épique en Yougoslavie.” Reuue des Études Slaues, 13:16-50.

. Tragom srpsko-hrvatske narodne epike: Putovanja u godinama 19301932. 2 vols. Zagreb: Jugoslavenska akademija znanosti i umjetnosti.

"The Singers and Their Epic Songs." Trans. by John Miles Foley. Oral Tradition, 5:107-30. http://journal.oraltradition.org/issues/5i/murko

Vladan Nedić. Vukovi pevači. Beograd: Rad.

Jeff Opland. "Lord of the Singers." Oral Tradition, 3:353-67. http:// journal.oraltradition.org/issues/3iii/opland 
Parry 1971

Pričanje I

Pričanje II

Pričanje III

Pričanje IV

Pričanje $V$

Pričanje VI

Pričanje VII

Ranković 2012

Ranković and Ranković 2012

Ritchie 1993
Adam Parry, ed. The Making of Homeric Verse: The Collected Papers of Milman Parry. Oxford: Clarendon Press.

Salih Ugljanin. Pričanje I. Novi Pazar, November 15, 1934. MPCOL. Text: http://pds.lib.harvard.edu/pds/view/2588060?n=1 Audio: http://nrs.harvard.edu/ urn-3:HLNC.MPCOL:863970

Pričanje II. Novi Pazar, November 16, 1934. MPCOL. Text: http:// pds.lib.harvard.edu/pds/view/2588062?n=1 Audio: http://nrs.harvard.edu/ urn-3:HLNC.MPCOL:862910

. Pričanje III. Novi Pazar, November 17, 1934. MPCOL. Text: http:// pds.lib.harvard.edu/pds/view/2588063?n=1 Audio: http://nrs.harvard.edu/ urn-3:HLNC.MPCOL:862911

Pričanje IV. Novi Pazar, November 18, 1934. MPCOL. Text: http:// pds.lib.harvard.edu/pds/view/2588064? $\mathrm{n}=1$ Audio: http://nrs.harvard.edu/ urn-3:HLNC.MPCOL:927635

Pričanje V. Novi Pazar, November 19, 1934. Transcript scans courtesy of MPCOL.

Pričanje VI. Novi Pazar, November 20, 1934. MPCOL. Text: http:// pds.lib.harvard.edu/pds/view/2588065?n=1 Audio: http://nrs.harvard.edu/ urn-3:HLNC.MPCOL:879280

. Pjevanje i pričanje. Novi Pazar, November 24, 1934. MPCOL. Text: http://pds.lib.harvard.edu/pds/view/2587645?n=1 Audio: http://nrs.harvard.edu/ urn-3:HLNC.MPCOL:1068575

Slavica Ranković. "Authentication and Authenticity in the Sagas of Icelanders and Serbian Epic Poetry." In Medieval Narratives between History and Fiction: From the Centre to the Periphery of Europe, 1100-1400. Ed. by Panagiotis A. Agapitos and Lars Boje Mortensen. Copenhagen: Museum Tusculanum Press. pp. 199-233.

Slavica Ranković and Miloš Ranković. "The Talent of the Distributed Author." In Modes of Authorship in the Middle Ages. Ed. by Slavica Ranković with Ingvil Brügger Budal, Aidan Conti, Leidulf Melve, and Else Mundal. Toronto: Pontifical Institute of Mediaeval Studies. pp. 52-75.

Susan Ritchie. "Ventriloquist Folklore: Who Speaks for Representation?" Western Folklore, 52:365-78. 
Saussy 2006

Schmaus 1938

SCHS I

Spivak 1988

Sremac 1894

Swift 1983

Škaljić 1966

Tate 2010

Vasenkari and Pekkala 2000

Wood 2005
Haun Saussy, ed. Comparative Literature in an Age of Globalization. Baltimore: The Johns Hopkins University Press.

Alois Schmaus. "Beleške iz Sandžaka." Prilozi proučavanju narodne poezije, $5: 274-80$.

Milman Parry, coll., and Albert B. Lord, ed. and trans. Serbocroatian Heroic Songs. Vol. 1. Novi Pazar: English Translations. Cambridge, MA, and Belgrade: Harvard University Press and the Serbian Academy of Sciences. 1954.

Gayatri Chakravorty Spivak. "Can the Subaltern Speak?" In Marxism and the Interpretation of Culture. Ed. by Cary Nelson and Lawrence Grossberg. Basinstoke: Macmillan Education. pp. 271-313.

Stevan Sremac, ed. Nasradin-hodža: njegove dosetke i budalaštine u pričama. Beograd. Štamparija V. Valožića.

Graham Swift. Waterland. London: William Heinemann.

Abdulah Škaljić. Turcizmi u srpskohrvatskom jeziku. Sarajevo: Svjetlost.

Aaron P. Tate. “"There Were Two Foreigners and One of Ours': Parry and Lord in Kijevo, Croatia, 24 September 1934." Folklore, 121:311-20.

Maria Vasenkari and Armi Pekkala. "Dialogic Methodology." In Thick Corpus, Organic Variation, and Textuality in Oral Tradition. Ed. by Lauri Honko. Helsinki: Finnish Literature Society. pp. 243-54.

David Wood. The Step Back: Ethics and Politics after Deconstruction. New York: State University of New York Press. 
This page is intentionally left blank. 
Oral Tradition, 27/1 (2012): 67-84

\title{
Oral/Aural Culture in Late Modern Society? Traditional Singing as Professionalized Genre and Oral-Derived Expression
}

\author{
Ingrid Åkesson
}

This article discusses some expressions and elements of orality and aurality in late modern society, and the roles, functions, and limitations of these expressions. Traditional song of different cultural origin has been the subject of much analysis and scholarship within the areas of orality studies, ballad studies, and several other related fields. However, songs and singing are in many cases analyzed chiefly as verbal art and verbal performance, while less attention is given to the closely interwoven texture of words, music, rhythm, and timbre, or to the balance between verbal and music-related sides of orality. I think more frequent discussions between scholars within the disciplines of folkloristics, literature, linguistics, and ethnomusicology might be fruitful. Initiatives of this kind are continuously taken in conferences and publications, and a couple of interesting texts on musical aspects have recently been published in Oral Tradition itself. $^{1}$

My own discipline is ethnomusicology, and my topic is traditional singing (or vocal folk music) in a Northern European and especially Swedish/Scandinavian context, viewed as a contemporary cultural—verbal and musical — expression, and partly as an established sub-genre within the genre or field that is today labeled "folk music" or "folk and world music." There are reasons to ask, in the early twenty-first century, what the consequences are for oral-derived singing and music-making in an era of accelerating professionalization, institutionalization, and formalization. Which elements and expressions of orality function in a cultural environment characterized by fast changes, access to innumerable cultural items, and music as a mediatized, processed, and often digitized phenomenon? And what are the consequences for affinity-centered and long-term qualities of oral tradition, such as learning songs across the kitchen table and performing and developing one's repertory during a lifetime?

This essay is based on my studies of the Swedish/Scandinavian contemporary folk music scene with some references to earlier periods of time and other European/Western music cultures. It is my belief that, despite these geographic and cultural limitations, several of my

\footnotetext{
${ }^{1}$ See Foster 2004 and Sborgi Lawson 2010.
} 
observations are relevant in the wider context of the tension fields ${ }^{2}$ traditional-revival-postrevival as well as oral/aural-literate/mediated in a transnational and transcultural perspective. The larger research project with which the current essay is associated focuses on music-making as an activity and meaning-making phenomenon at small-scale events, where the modes of performance may shift to and fro between the participatory and the presentational. ${ }^{3}$ This approach is in contrast to the strongly dominant discourse on music-and other cultural expressions - as products that are made by the few for the reception and consumption of the many. Thus the project includes what might be called contemporary expressions of oral/aural tradition in late modern mediatized society. ${ }^{4}$

Traditional singing in the Scandinavian cultural area includes ballads and other narrative songs, lyric songs, jocular songs, lullabies, work songs, hymns and religious songs, and short ditties of several kinds. The vocal tradition also comprehends two wordless types: the one is diddled dance tunes and the other is herding calls that are performed outdoors with the use of a special voice technique. Both of these wordless types, as well as singing, have played an important role in the establishment of vocal folk music as a "genre" in the post-revival sense. Diddling, or trall, in the Scandinavian/Nordic area shows some likeness to the Celtic and British tradition of "mouth music." Non-semantic syllables are used in a rhythmical fashion that imitates the movements of the bow on the strings of a fiddle. The technique has been used for the accompaniment of dancers as well as for transmission of tunes; today it is performed as dance music or at concerts. Herding calls, which likewise are used at concerts and in musical arrangements, have been performed chiefly by women (and children) since cattle herding belonged to the feminine sphere of earlier rural society as a result of the gendered division of labor. There is more documentation of men having sung, for example, military songs or shanties and of women having sung ballads and lullabies, but except for the calling there are no formal gendered or age-related restrictions concerning repertory.

Besides oral transmission, song lyrics have been disseminated and transmitted via chapbooks, mainly from the eighteenth century onwards, and later by way of printed as well as hand-written song books. Singing has been performed chiefly in a domestic context, unaccompanied and often combined with story-telling and talk, while instrumental dance music and ceremonial tunes have belonged to the more public and presentational sphere of life.

2 I use the concept "tension field" since it allows for continuity and several conceivable positions along a scale between oral and literate. Fields of tension may have more than two poles and make up a multi-dimensional sphere of energy (Lundberg et al. 2003:63), meaning that concepts are not regarded as dichotomies but as containing possible overlap (cf. Finnegan 1988:125). Likewise, tradition, revival, and post-revival may be regarded as overlapping fields; see Figure 1 below.

${ }^{3}$ Cf. Turino 2008. Turino's definition of presentational performance emphasizes a clear distinction between artist(s) and audience, and the musicians' attention divided between themselves, the musical product, and the audience. The participatory mode is characterized by music-making as social intercourse among face-to-face participants; the roles of performer and audience may shift within the group, and focus is directed inwards (90).

\footnotetext{
${ }^{4}$ I am also here building on earlier field work, presented in Åkesson 2006 and 2007.
} 


\section{Orality and Literacy in Text and Music}

Let me begin by presenting some basic presuppositions and departure points for this article. As stated, my approach to the fields of orality, literacy, and mediation is from the viewpoint of ethnomusicology. I am primarily concerned with singing on a number of levels: lyrics, melody, tonality, style, content and meaning, transmission, performance, and contexts of performance. As the concept of orality—or oral tradition — is broad and multi-faceted, and verbal art and linguistics are not my own area, I speak rather of "expressions or elements of orality" in this article.

a) Orality in traditional singing has, of course, much in common with verbal arts such as story-telling or spoken poetry, but also with other kinds of music-making by ear; singing combines verbal and musical orality. I allude to music-making that makes no or little use of notation or sheet music but that is based on memorization as well as on variation and improvisation within frameworks, for instance, jazz and blues or Arabic and Indian art music (cf. Lilliestam 1995, Foster 2004).

b) When discussing singing, I use the combined concept of oral/aural with its stress on learning by listening, by ear, in the present, irrespective of which modes of transmission have been used in the past. The German terms Gehörskultur and Gehörsmusik (generally used in much European literature) can be said to cover both oral and aural culture/music. The concept Gehör also has more general connotations to aurality as a wider concept in music-making as a whole. In this case it stands for singing or playing by ear, without using sheet music (even if the performer can read it and the music is composed and written down) and regardless of musical genre. Gehör, or aurality in this wider sense, is not necessarily associated with elements like family or local tradition, formulas, and variation that are included in "oral culture." Gehör in an even wider sense is sometimes used in everyday speech for something you do by ear, or from experience and (tacit) embodied knowledge, without using a written or printed model, recipe, or prescription. The term may also be used in relation to the skill of a person who has a good sense of what is correct and of what constitutes fluent spoken and written language, learned more by ear and through reading than by studying grammar.

c) Concepts such as literacy, writing, and print may be primarily associated with the lyrics, the literally textual side of songs and singing. However, they also allude to different kinds of notated musical transcriptions, to the skill of reading and using notation (notated "text"), and to the phenomenon of music in literary or 
written circulation. ${ }^{5}$ The basic meaning of the concept mediation is that music, speech, and other such elements are conveyed to their recipients via media, that is, in almost every way that is not direct and simultaneous aural communication (cf. Lundberg et al. 2003:68). Mediation includes literacy as well as the use of wax cylinders, tape recordings, CDs, MP3 files, and other types of sound recordings; it also includes film and video, and analog as well as digital media. Mediatization implies that items - in this case musical — are changed and adapted in ways that are decided by the structure of the media system (idem). It also implies that recorded, arranged, and mediatized versions of traditional songs or tunes become models and might be the only versions known to younger generations.

d) Another basic notion is that oral/aural qualities as well as approaches and techniques associated with writing, printing, or other kinds of mediation are usually to some degree simultaneously present in most societies, historically as well as today. As Ruth Finnegan has pointed out on several occasions, orality and literacy might be regarded as a continuum rather than as separate modes; they are processes for representing and communicating information that take diverse forms in differing cultures and periods, and that mutually interact and affect each other (1988:125). Many of today's scholars are well aware that elements of orality and literacy are intermixed rather than separated in the long-term transmission of traditional culture over centuries and generations in many parts of the world. ${ }^{6}$

Some examples of this intermixing are available from my own field: since the eighteenth century in Scandinavia, and earlier in many parts of Europe, songs of both oral and literary origin have been printed in broadsheets and chapbooks in a process simultaneous with that of oral transmission. There are numerous examples of both narrative and lyrical songs that are found in both oral/aural and literate circulation. As the lyrics accordingly in some cases have been learned or supplemented from the page, the printed versions have had some influence on, for example, the ballad tradition (cf. Jersild 2005). On the other hand, literary poems written by established authors and printed in chapbooks have entered the oral process and resulted in an endless number of variants. We do find some variability in many kinds of printed texts, for instance, in songs and poems; they are not completely stable but reveal a blurred area between the Text with a capital $\mathrm{T}$ and versions/variants in the plural (cf. Atkinson 2002:25). Further, though song texts may have been learned from the page of a chapbook or a song book, the print has often been put aside after a while, and the song has entered into the singer's orally maintained repertory. There are examples of the reversed process as well: many singers have written down newly learned song texts or copied song texts from others' collections for their own use. Some of these songs have

5 One line of thought within musicology accentuates the notion of music as a visual and literary phenomenon by approaching musical notation as a system of signification in its own right (as opposed to a mere representation of musical sound), focusing on "correctness" and, for instance, graphic scores (cf., for example, Wadle 2010).

6 Atkinson 2002:1-38 contains a good overview of this discussion with ballads as a starting point, with references to, among other topics, reception theory and traditional referentiality (cf. Foley 1991). 
entered the singer's active repertory, but others have seldom been performed and may rather be regarded as passive items in a collection (Ternhag 2008).

However, we should remember that both the popular circulation of broadsheets and chapbooks and the existence of hand-written song books imply a literacy that is restricted to the lyrics. Tunes have chiefly - in vernacular contexts and milieus more or less exclusively — been transmitted in oral/aural ways, far into the twentieth century, and into our own time. Likewise, performance style and also more general skills in traditional music-making have been transmitted aurally; in fact, these can only be transmitted aurally, whatever the music genre. Traditional singers have very seldom been able to use notation; this is one of the differences between the vocal and the instrumental traditions. Some fiddlers and other instrumentalists in the vernacular community have been able to read and write music; in eighteenth- and nineteenth-century Sweden it was primarily musicians who received their musical training in the military service who acquired this skill, while many peasant instrumentalists have played only by ear even into the twentieth century (a statement that of course says nothing about the respective quality of their performance). In the case of printed texts as well as notated music, these resources seem to have been used in vernacular and aural-dominated milieus mainly as a support for memory, or as a skeleton for a multi-faceted performance. Although there are numerous examples of songs that have been influenced by print and other forms of literacy, the transmission process as a wholeand the individual actors in the process - have maintained a high degree of oral-derived qualities, especially in the transmission of melodies.

\section{Oral Elements in Living Tradition, Revival, and Post-Revival}

What position, then, do verbal and musical oral elements hold today, in the late modern folk and world music scene of Sweden-and other countries or areas with similar characteristics? Are different expressions of orality found in different parts of the milieu? To begin, I would say that the present situation is characterized by roughly three partly overlapping and intermingling trends (see Figure 1 below) $:^{7}$

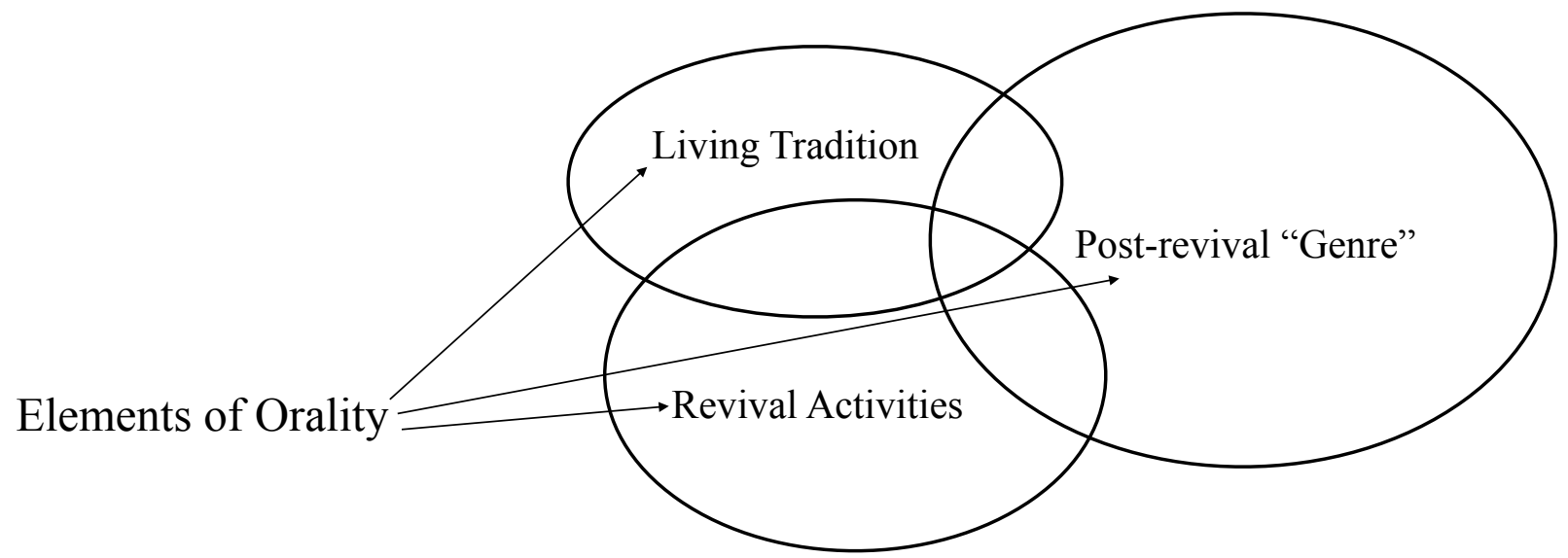

Figure 1: Three intermingling trends in late modern folk music.

\footnotetext{
${ }^{7}$ This model can be regarded as an extension of Tamara Livingston's model for revivals (1999).
} 
There is the so-called post-revival folk music "genre," which is largely institutionalized, professionalized, and characterized by a great deal of arranged and technically processed music that is performed at large concerts and festivals as well as published as digital sound recordings by small or large companies. But we also find strands of living tradition, especially in certain musical families and in tradition-conscious areas. These strands run parallel with, and partly overlap, strands of what might be called "revival activities" - activities that rest on (and are rather similar to) the 1960 s and 1970 s vogue of revival or revitalization (see also Åkesson 2007:104). The "living tradition" and "revival" milieus are both mainly small-scale phenomena of the participatory and inclusive kind, in which aesthetic and social values intertwine. Phenomena such as unplugged performance, unaccompanied singing, face-to-face interaction, and a lower degree of formality characterize these milieus and can be contrasted to the greater amount of formality and organization, the elaborate instrumental arrangements, the big localities, and large audio systems along with extensive sound checks that characterize big festivals. This is not a question of absolutely separate worlds; the same musicians may partake in different kinds of events, and some festivals include participatory spaces such as workshops and jam sessions. However, one visible tendency since the 1980s has been the gradual increase in restrictions on musical meetings outside the festival stages and a greater distance between artists and audience (cf. Ronström 2001).

The quantity, or strength, of living tradition is not as great in Swedish vocal traditional music as in instrumental music, partly due to the greater amount of interest and resources available for the performance, collection, and publication of instrumental music and dance during the twentieth century. Instrumental music and dance music also had stronger positions in the manifestation of national and regional identity (cf. Boström et al. 2010). Furthermore, folk music collection was primarily done with pen and paper; only a few collectors used the phonograph, and sound recordings became common only as late as the 1940s. This means that we have very few sound recordings of traditional singing from the first half of the twentieth century. There is also a visible gap between generations, which becomes manifest in traditional singing. The revival started rather late, in the years around 1970, when few traditional singers were still active in the rapidly modernized Swedish society. This situation can be compared to the British, Irish, and North American revivals that were well under way in the 1950s and to a great extent overlapped with the existence of strong strands of living tradition (cf. Brocken 2003; Russell and Atkinson 2004). The generation gap has of course had its impact on the nature and amount of oral/aural transmission of singing traditions.

Another influential feature, common to many cultures or countries, is the fact that traditional songs often have been performed publicly by opera singers, by choirs, and in schools. In that process they have been adapted into a more or less classical idiom; they have become estranged from their oral context and - maybe most important of all-they have become known to most people in that idiom. The music hall or revue scene also set its imprint, especially on the comical songs.

One consequence of these factors is that the general idea of traditional song has been rather strongly influenced by an aesthetics that is nearer to the literate and the fixed than to oral tradition. Another consequence of the generation gap and the lack of direct person-to-person transmission of performance skills is that we are very much dependent today on archival field 
recordings for the study and transmission of musical style elements such as phrasing and ornamentation or the way to carry forward the narrative or content of the song - that are present only in the individual performance. Similar situations seem to be found in other Western cultures, ${ }^{8}$ which makes this an important empirical starting point for studying different elements of orality in the present. In the following sections, I would like to concentrate on these questions:

- Which elements of orality and aurality can be clearly discerned today and how are they used?

- What is the relationship between these elements and what might be called long-term and affinity-centered qualities of oral culture?

- What are the consequences of the present-day mixture of face-to-face oral and "mediated aural" transmission?

\section{Contemporary Elements of Orality: Transmission, Techniques, Ideals, and Style Markers}

In consideration of the first of these questions, I will briefly discuss present-day forms of oral/aural transmission, the use of oral/aural techniques, and the characterization of traditional music or folk music as a "genre" or a micromusic (Slobin 1993) in terms of oral/aural ideals, especially aesthetic ideals, and style markers. These phenomena are clearly discernible in all parts of the folk music milieu; they are present as inherent elements of traditional music or as more or less consciously used tools (the degree of consciousness or intent depending on the individual and the context). However, they do not, of course, constitute a comprehensive mapping of "present-day orality." There are sides of oral/aural transmission-and oral-derived culture as a whole - that relate to affinities, to face-to-face encounters, to participation and blurred boundaries between performer and audience, and to the singers' and listeners' lifeworlds and horizons of understanding. These relations and horizons are subject to constant change; I will come back to this idea later.

While discussing the Stewarts of Fetterangus, a Traveler family of singers, pipers, and story-tellers from northeast Scotland, the folklorist Tom McKean writes that in a family with a musical and verbal tradition of that kind, in spite of the use of literacy in several forms over a long period of time, "the horizontal 'tradition as personal relationship' . . . is fundamentally unchanged in form and in function" throughout the twentieth century (2004:182). This description is relevant for many twentieth-century contexts and for many cultures. It may be said that this horizontal process is still discernible with many revival and post-revival singers, although the vertical oral transmission between generations has ceased. A horizontal oral/aural transmission of songs and tunes, from person to person, is fairly widespread, is encouraged by teachers of traditional music, and is regarded as the most important type of learning among most folk singers.

But how does person-to-person transmission function in a late modern context? Is the amount and impact of literacy, mediation, and institutionalization so much greater today that the

\footnotetext{
${ }^{8}$ Cf. Ramnarine 2003 and Hill 2005 on Finland.
} 
horizontal transmission changes its character? Many personal relationships are of a much more temporary and formalized kind in the twenty-first century - they might still be personal, but in the context of a music course or a series of workshops rather than in the context of a family or a local community, and one does not learn songs over the kitchen table again and again from the same person. Is it, then, the same qualities that are transmitted in this contemporary oral/aural process?

Oral/aural transmission of songs, tunes, and style is consciously used as a pedagogical tool in traditional music education by teachers who themselves started out in the revival of the 1970s in Sweden, or who were themselves taught by revivalists. (We find a similar situation in Finland, especially at the Sibelius Academy of Helsinki; see Hill 2005.) An important issue of the revival was to replace the use of notation with learning by ear from live musicians, or from archival recordings, thus focusing on playing and singing style, idiom, sound, and individuality rather than just the songs and tunes. Pedagogues urge students to return to the sounding sources - the archival recordings - and to learn to master the idiom and style of traditional music, that is, to work orally and aurally. It is a common notion that if you have managed to master the idiom and use the tools you have acquired, you can learn songs and tunes also from print and notation and perform them in the same way as the songs you have learned directly from another singer (cf. Åkesson 2007:166, 228).

As very few people today are brought up immersed in family or local tradition, few singers learn songs by hearing them from childhood onwards. The most common ways to learn traditional music are to attend workshops and courses or to learn from recordings. If you want to become a professional musician, you probably train at one of the music colleges that nowadays include traditional music. Oral transmission is re-contextualized into the education system. I would argue that it is also being re-negotiated through the combination of, on the one hand, (horizontal) face-to-face transmission by ear and, on the other hand, field recordings as well as the use of recording equipment such as cell phones or mini discs in the classroom setting, where students record the singing of their teachers and their fellow students and learn songs that way. This interchange between face-to-face transmission and recordings is part of what I call "mediated aurality." By this term I allude to a conscious recycling process: a sound recording of one separate performance represents one frozen version of a song, but by learning the song and creating one's own individual version of it, that is, by subjecting it once more to variation and interpretation, this recorded and acquired item may be "recycled" or re-entered into a process that is chiefly oral/aural, though certain levels are out of necessity mediated. The process comprehends obvious oral elements as long as the song is not a fixed version but subject to possible continuous change and variation with each new singer. ${ }^{9}$

The educational use of mediated aural transmission is a characteristic of this era of disembedded traditions, when knowledge of traditional material is to a great extent institutionalized and the acquisition of this knowledge is part of an education. But the

${ }^{9}$ However, the song in question may at a certain time become fixed and elaborately arranged, recorded, or performed on a big concert stage and disseminated to many listeners in that form; thus it becomes subject to another, more decidedly mediated and mediatized type of change. In this shape the song has become more of a work of art; it is much more difficult to imagine this version's re-entrance into something that might be termed oral tradition. Cf. Glassie 1995. 
phenomenon is not merely connected to present-day audio and recording technologies; there is a similarity to the way song texts have moved between oral transmission and printed media such as chapbooks. The element of mediation or literacy leaves a trace but does not make the whole chain of transmission non-oral. Another parallel is instrumental tunes being learned from transcriptions (when these are the only existing source material) but internalized and in the next phase played and taught only by ear (cf. Ramsten 1991). For these wanderings between written or sound recordings on the one hand, and present-moment orality on the other, we may use the terms de-mediatization and re-mediatization. ${ }^{10}$

A widely disseminated concept is, of course, "secondary oral tradition." But if we look at transmission of songs historically as an intermingling of oral and literate or mediated elements, it is not easy to decide exactly where the border lies between "primary" and "secondary." How much influence from mediation or literacy is accepted within a process that we may term "chiefly oral" or "oral-derived" is an open question; as Ruth Finnegan pointed out (1988:125), the literary and oral modes mutually interact. One point of view here might be that time and maturation are crucial for the recycling of a musical item into an oral-dominated process: the singer or musician in question needs to put the recording or sheet aside and internalize the song or the tune, performing it again and again over a long time, and develop her/his own individual version in terms of nuances, ornamentation, and variability. This is the declared intention and acknowledged ideal from the teachers' side, but there is not much space today in the "folk and world music" genre for the time-consuming maturation that characterizes oral transmission as a wider concept.

Oral/aural techniques for textual and musical re-creation, transformation, arrangement, and other such processes differ from the ones typical for literature or musical notation. These techniques may be used intentionally or unintentionally, consciously or unconsciously. Some contemporary Swedish performers and teachers have analyzed older singing styles in archival recordings, both for their own use and to create pedagogical models. These oral/aural techniques are now taught in contemporary folk music education. Some of them concern a micro level of performance, such as ornamentation, the use of grace notes, slight changes of wording, or the phrasing of the melody in free rhythm. Others concern macro level changes and exchanges of text and melody, such as adding or omitting phrases, stanzas, or motifs; making compilations of different text variants; or exchanging refrains or melodies.

My more extensive study (Åkesson 2007) of ballad singing in the present as well as in older sources can provide examples of such oral/aural techniques. If we observe the variation and transformation of ballad singing in historical sources (including written documents) and compare it to present-time arrangements, we of course become aware of differences: in older source material the singers often seem to have reinforced oral elements such as incremental repetition and parallelism, while today most musicians tend to shorten the length of the ballad, omit repetition and parallelism, and replace them with instrumental introductions and interludes. These latter techniques demand some degree of musical literacy as a prerequisite, as well as a general modernist and "non-traditional" approach to lyrical and musical material. Literacy and

10 Cf. Lundberg et al. 2003:68, where the authors use the terms de-mediaization and re-mediaization, coined by Roger Wallis and Krister Malm (1984). In this text I use the forms de-mediatization and re-mediatization respectively, in accordance with the general use of the term mediatization. 
mediation probably also lie behind the wide-ranging use of bricolage because of so many versions being accessible in print or in sound recordings and thus inviting singers to mix and blend; bricolage is certainly also an element of late modernity. The same prerequisites lie behind the elaborated musical arrangement - used with inspiration from other genres - such as changing melody and meter within a song. Naturally, most of these oral/aural techniques are common to several song cultures and not specifically Scandinavian. ${ }^{11}$

The following techniques that are used today seem to be oral-derived:

- borrowing stanzas from other ballads

- borrowing refrains from other ballads

- completing the narrative

- stressing certain motifs

- melodic variation (ornaments, intonation, and so forth)

- minor changes to text

- creating stanzas from formulaic elements

- creating new melodies

These techniques are all parts of an orally/aurally dominated transmission, and are today used rather spontaneously as well as taught in folk music education, which means that they constitute a strong element in contemporary performances. Certainly these techniques are used much more intentionally and consciously today, and in more formalized contexts. Elements of orality and aurality are formalized in late modern society.

Orality/aurality may also be discussed in the context of a genre's style and aesthetic ideals. These ideals are shown through the use of style markers, which are derived from and modeled on archival recordings, filtered through contemporary performers' notions, and influenced somewhat by idioms of world music, early music, chamber music, jazz, and rockthat is, genres that are characterized by both orality and literacy. Some of the revival pioneers have approached songs and singing mostly intuitively, absorbing some stylistic traits from their models but without verbalizing this process. Other pioneers have analyzed, verbalized, and constructed pedagogical models for teaching and transmitting older singing styles (cf. Åkesson 2007:214). The point here is that whether they are verbalized or not, the ideals are based on aural sources.

Again, because of the lack of living tradition in the shape of live, traditional, unaccompanied, and unarranged singing in contemporary formal or informal contexts, singers as well as scholars in Sweden depend very much on archival sound recordings. There are also other kinds of sources - for instance, literary descriptions from the eighteenth and nineteenth centuries, earlier collectors' field notes, and the collectors' transcriptions of tunes as both drafts and fair copies - that give us information about the way traditional singing was performed before the strong impact of school and choir singing, radio, and gramophone records in the early twentieth

\footnotetext{
${ }^{11}$ See, for example, Sweers 2005 on similar elements in the English folk song revival.
} 
century. ${ }^{12}$ To be able to make what we may call more or less "historically informed" performances and interpretations of songs (or "historically informed" scholarly presentations and analyses) we must use all these sources.

Some important style markers regarding singing style that have been put forward by scholars and pedagogues are the following: ${ }^{13}$

- chest voice

- relatively low women's voices and high men's voices

- no "classical" vibrato

- placing of sound in the front part of the voice cavity

- approaching the pitch from below or above

- the use of sounding and even ornamented consonants

- grace notes applied individually, with a blurred boundary to ornaments

- ornamentation ruled by sound and phoneme qualities, not semantic ones

Several of these style elements are to be found in traditional singing from different parts of the world, and also in classical singing from areas outside the Western world, but they are seldom found in Western school or choir singing. Most of them are impossible to discern from written music (except for some ornaments and grace notes); they must be learned by ear, by an aural process. Style elements such as these have become an important means for giving traditional music as a genre its profile - contrasted to traditional songs performed by choirs or by classically trained singers. The highlighted stylistic traits are, of course, selected in one way or another by pioneers of the vocal revival as well as by scholars. ${ }^{14}$ This ambition to (re)construct a singing style should be regarded as a parallel to a similar process that took place among fiddlers about two decades earlier, which highlighted drones and other older musical elements such as multistringed bowing techniques.

What we see here is roughly a question of fortifying certain style markers from earlier layers of time, and of combining ideals of the ancient with ideals of the unusual. The style markers or stylistic traits were certainly present in the performance of older singers, but in many cases they were not all present simultaneously in the performance of one individual. Some of the younger singers today, however, use many of the style elements at once, and more frequently than in archival recordings. The need to identify a contemporary style or genre of traditional music among a great number of available genres has led to what Ramsten terms "fortified tradition" (1992:37). There is also a strong connection to the focus on musical performance and

12 There have been extensive discussions on source criticism associated with the transcription of traditional music, not least because of the late introduction of sound recordings by Swedish collectors. For an overview, see Jersild and Åkesson 2000.

${ }^{13}$ Cf. Jersild and Ramsten 1988; Rosenberg 1993; Jersild and Åkesson 2000, chapters 8 and 9.

14 I would like to emphasize that this analytical work has been carried out in a cumulative way, where Scandinavian (mostly Swedish and Norwegian) scholars and singers/pedagogues have alternated and used each other's analyses. 
voice qualities, rather than on narrative and content, in the Swedish vocal vogue of the $1980 \mathrm{~s}$ onward (cf. Åkesson 2007:301).

\section{Oral Techniques and Style Markers versus Oral-Derived Culture in a Wider Sense}

Traditional music is a large, disparate, multi-faceted body of text, music, styles, persons, content, and contexts. It is a common cultural heritage, which is continually both created and handed down. Today it is also a subculture, a micromusic or "genre." This dual nature certainly raises some questions about the quantity, the qualities, and the characteristics of present-day orality. Much of the present-day use of oral/aural transmission, techniques, and style markers is associated with the institutionalized and professionalized folk and world music milieus, where identity as a musician is a matter of both status and making a living. Many of the more affinityrelated and participation-centered values are stronger in small-scale, living tradition or revival circles, in which musical identity may embrace a wider and more holistic field. If we regard these contexts as both separate and overlapping, as I proposed at the beginning of this article, the pattern might be illustrated as in Figure 2.

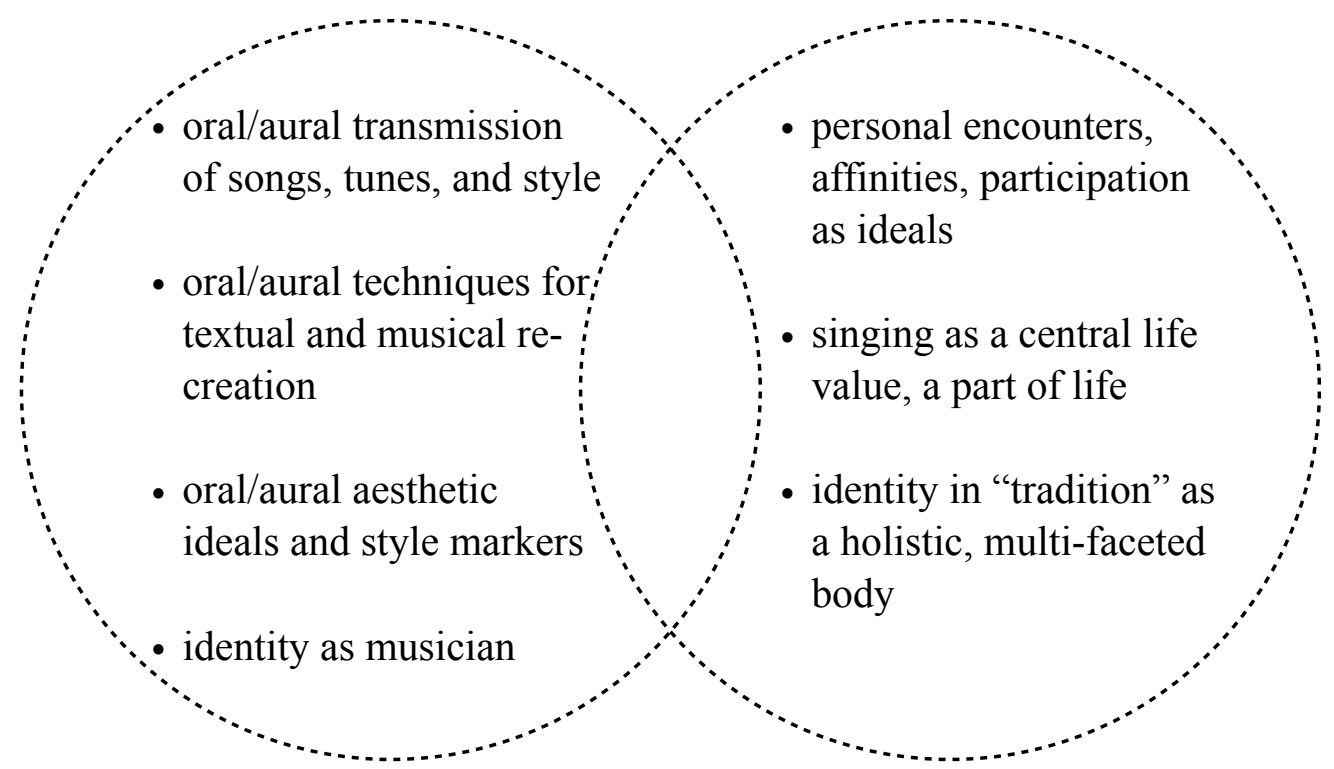

Figure 2: Ideals in different but overlapping contemporary folk song milieus.

When orality and aurality are regarded as ideals and techniques as in the discussion above, they are attached primarily to the aesthetic and formal side of singing and represent a rather narrow aspect of orality. The ideals and techniques are associated with performance-asform and performance-as-sound. In becoming a tool, orality in this sense runs some risk of being regarded as a technical quality of transmission and performance. There is less space for other qualities of oral culture, such as those attached to singing as a central life value and as an important everyday activity; that kind of approach was expressed by many older singers in archival interviews. There is also less space for personal relations to forerunners and affinities for 
singers not only as singers and sources of information, but also as individuals. Some young professional folk musicians with a conservatory education, several of whom try to make their living as artists, seem to stress idiom more than affinity and emphasize richness of arrangement more than richness of repertory. Many are not particularly interested in, for example, the maintenance of traditional repertories as such. In a more "traditional" context, the singers who knew many songs were regarded as good and important singers; they were the keepers of collective memory. Besides repertory, the singers' general knowledge of tradition and local history was valued together with their performance, story-telling ability, style, and voice quality.

Today, in late modern society, there has been a shift of focus: it is primarily style and voice quality, together with technical skill and elaborated arrangements, that are valued, just as they are in jazz or art music. This shift is understandable when many try to make a living through their music-making; we are regarding the inevitable consequences of professionalization and a closer connection to official cultural institutions as well as to the music market. In this process, however, traditional music becomes something performed by the few for the consumption of the many, rather than performed in a company where the roles of listener and performer shift to and fro, and where participatory and presentational sides of performance are valued as equal. This development indicates a doubtful future for oral culture regarded as a broader phenomenonalthough I, of course, have made some simplifications in order to render a clear image of the present situation.

Formalization and institutionalization are no doubt necessary processes for the future existence of traditional music in late modern society. It would, however, be an oversimplification to regard the present as a post-traditional society (cf. Giddens 1994) and focus merely on "orality as a tool." A great part of the concert and festival audience consists of people who are involved in different kinds of informal, small-scale activities that are more closely connected to affinities, everyday aesthetics, and lifeworlds. Within the field of traditional music, both dancing and playing of an instrument lead quite a strong existence as participatory cultural expressions, and singing is not wholly dedicated to stage performance. Outside that field there is little general interest in expressions of immaterial oral culture in Swedish society, and folkloristics has ceased to exist as an academic discipline. However, a revival of story-telling started in the 1990s.

Further, oral tradition as a wider concept contains and rests on, among other things, a great amount of extra-musical and extra-textual knowledge, which is probably also necessary for the future understanding of traditional culture. When listening to old songs, tales, or other expressions of oral-derived culture, the audience needs some knowledge of the background and the genre to make the sometimes obscure texts-or modal tunes-comprehensible. In small communities, traditional singing has been performed as communication between a singer and a knowledgeable audience, with different individuals taking turns as performers and with a sufficient distribution of knowledge covering the need for traditional referentiality (Foley 1991). 
This kind of knowledge is mostly to be found in small-scale folk music milieus today, where enthusiasts strive to create and make accessible common frames of reference. ${ }^{15}$

The acquisition of knowledge and skill in songs and singing, as well as extra-musical and extra-textual knowledge, are time-consuming procedures, and are issues involved with maturity. A feature common to oral and oral-derived traditions worldwide is the notion that it takes time to become a performer or an expert; it takes more than skill and necessitates internalizing one's own life experience into performance. Becoming a singer or story-teller is regarded as a lifelong mission or object, not a pastime to which one gives a couple of years and then leaves for something else. But here is another of the current obstacles for the long-term qualities of oral traditions: today one is expected to move on through life from one project to the next, and to alternate between different cultural areas. There is little time and space in an educational curriculum for a deep immersion in a tradition, even though most teachers try their best to stimulate their students to continue studying on their own. However, there is a certain amount of fluidity in the musical and social spaces; there are blurred boundaries and some comings and goings between the institutionalized and professionalized milieus on one side and the informal revival circles on the other. In that kind of exchange are probably embedded the possibilities, such as they are, for a continuance of wider oral/aural values and qualities.

\section{Conclusion}

In late modern societies traditional arts tend to become disembedded from a functioning vernacular milieu and at least partly become absorbed into institutionalized and formalized structures. Traditional singing in present-day Sweden is one evident example of an area where oral tradition as a comprehensive concept, characterized by elements such as affinities to tradition-bearers, long-term immersion, and participatory performance, is being transformed and renegotiated into a selection of oral techniques, style markers, and aesthetic ideals connected to the post-revival music scene as well as to music education. Oral transmission is to a great extent recontextualized and mixed with mediated aurality as an interchange between face-to-face, byear transmission and audiovisual recordings. Certain oral-derived elements, techniques, and ideals are being fortified and carried into the field of post-revival traditional music. It is rather in the simultaneously existing milieus where the strands of living tradition and revival are strong that we find other expressions connected to oral tradition, such as an emphasis on extra-textual and extra-musical knowledge, participatory ideals, and an idea of singing as meaning-making and a central life value.

University of Umeå, Sweden

\footnotetext{
15 Though such issues are beyond the scope of the current essay, I am aware that this kind of extra-textual knowledge should be further discussed in connection with the notion of musical or expressive specialists being appointed by knowledgeable peers (cf. Merriam 1964:123-40; Herndon and McLeod 1982:92-102); issues concerning ethnopoetics, the role of the audience, and traditional referentiality (Briggs 1988:5-22; Foley 1991:7-12 and 1995:6-11); and, furthermore, ideas of embodied knowledge.
} 


\section{References}

Åkesson 2006

Åkesson 2007

Atkinson 2002

Boström et al. 2010

Briggs 1988

Brocken 2003

Finnegan 1988

Foley 1991

Foley 1995

Foster 2004

Giddens 1994

Glassie 1995
Ingrid Åkesson. "Re-creation, Re-shaping, and Renewal Among Contemporary Swedish Folk Singers: Attitudes Toward Tradition in Vocal Folk Music Revitalization." Svensk tidskrift för musikforskning. STM-Online, 9. http:// musikforskning.se/stmonline/vol_9/akesson/index.php?menu=3

Med rösten som instrument: Perspektiv på nutida svensk vokal folkmusik. [With the Voice as an Instrument: Perspectives on Contemporary Swedish Vocal Folk Music.] Svenskt visarkivs handlingar, 5. Stockholm: Svenskt visarkiv. With CD. Summary in English.

David Atkinson. The English Traditional Ballad: Theory, Method, and Practice. Aldershot, UK: Ashgate.

Mathias Boström, Dan Lundberg, and Märta Ramsten, eds. Det stora uppdraget: Perspektiv på Folkmusikkommissionen i Sverige 1908-2008. [The Great Mission: Perspectives on the Folk Music Commission in Sweden 1908-2008.] Svenskt visarkivs skrifter, 27. Stockholm: Nordiska museets förlag.

Charles L. Briggs. Competence in Performance: The Creativity of Tradition in Mexicano Verbal Art. Philadelphia: University of Pennsylvania Press.

Michael Brocken. The British Folk Revival, 1944-2002. Aldershot, UK: Ashgate.

Ruth Finnegan. Literacy and Orality: Studies in the Technology of Communication. Oxford: Blackwell.

John Miles Foley. Immanent Art: From Structure to Meaning in Traditional Oral Epic. Bloomington: Indiana University Press. The Singer of Tales in Performance. Bloomington: Indiana University Press.

H. Wakefield Foster. "Jazz Musicians and South Slavic Oral Epic Bards." Oral Tradition, 19:155-76. http://journal.oraltradition.org/issues/19ii/foster

Anthony Giddens. "Living in a Post-Traditional Society." In Reflexive Modernization: Politics, Tradition and Aesthetics in the Modern Social Order. Ed. by Ulrich Beck, Anthony Giddens, and Scott Lash. Cambridge: Polity Press. pp. 56-109.

Henry Glassie. “Tradition.” Journal of American Folklore, 108:395-412. 
Herndon and McLeod 1982

Hill 2005

Jersild 2005

Jersild and Åkesson 2000

Jersild and Ramsten 1988

Lilliestam 1995

Livingston 1999

Lundberg et al. 2003

McKean 2004

Merriam 1964

Ramnarine 2003
Marcia Herndon and Norma McLeod. Music as Culture. 2nd ed. Darby, PA: Norwood Editions.

Juniper Hill. "From Ancient to Avant-Garde to Global: Creative Processes and Institutionalization in Finnish Contemporary Folk Music." Unpubl. Ph.D. dissertation, University of California, Los Angeles. http://juniperlynnhill.net

Margareta Jersild. "Ballader i skillingtryck: Om interaktion mellan tryckt text och muntligt traderad melodi." ["Ballads in Chapbooks: On Interaction between Printed Text and Orally Transmitted Tunes."] Noterat, 13. Stockholm: Svenskt visarkiv. pp. 51-62.

Margareta Jersild and Ingrid Åkesson. Folklig koralsång: En musiketnologisk undersökning av bakgrunden, bruket och musiken. [Traditional Hymn-singing: An Ethnomusicological Study of History, Performance, and Tunes.] Hedemora: Gidlunds.

Margareta Jersild and Märta Ramsten. "Grundpuls och lågt röstläge: Två parametrar i folkligt sångsätt." ["Individual Pulse Pattern and Low Pitch: Two Parameters of Traditional Singing.”] Sumlen 1987. Stockholm: Samfundet för visforskning. pp. 132-56.

Lars Lilliestam. Gehörsmusik: Blues, rock og muntlig tradering. [Gehörsmusik: Blues, Rock, and Oral Transmission.] Göteborg: Akademiförlaget.

Tamara E. Livingston. "Music Revivals: Towards a General Theory." Ethnomusicology, 43:66-85.

Dan Lundberg, Krister Malm, and Owe Ronström. Music, Media, Multiculture: Changing Musicscapes. Stockholm: Svenskt visarkiv/The Centre for Swedish Folk Music and Jazz Research. http://www.visarkiv.se/online/online_mmm.html

Thomas A. McKean. "The Stewarts of Fetterangus and Literate Oral Tradition." In The Singer and the Scribe: European Ballad Traditions and European Ballad Cultures. Ed. by Philip Bennett and Richard Firth Green. Amsterdam: Rodopi. pp. 181-208.

Alan P. Merriam. The Anthropology of Music. Evanston, IL: Northwestern University Press.

Tina K. Ramnarine. Ilmatar's Inspirations: Nationalism, Globalization, and the Changing Soundscapes of Finnish Folk Music. Chicago: The University of Chicago Press. 
Ramsten 1991

Ramsten 1992

Ronström 2001

Rosenberg 1993

Russell and Atkinson 2004

Sborgi Lawson 2010

Slobin 1993

Sweers 2005

Ternhag 2008

Turino 2008

Wadle 2010
Märta Ramsten. “Upptecknat 1897—inspelat 1984. Funderingar kring tradering och tolkning med utgångspunkt från Einar Övergaards folkmusiksamling." ["Transcribed 1897-recorded 1984. Thoughts on Transmission and Interpretation Based on Einar Övergaard's Folk Music Collection.”] Sumlen 1989. Stockholm: Samfundet för visforskning. pp. 25-48. . Återklang: Svensk folkmusik i förändring 1950-1980. [Reverberations: Swedish Traditional Music in a State of Change 1950-1980.] Göteborg: University of Gothenburg, Institution for Musicology.

Owe Ronström (with contributions by Krister Malm and Dan Lundberg). "Concerts and Festivals: Public Performances of Folk Music in Sweden." The World of Music, 43/2-3:49-64.

Susanne Rosenberg. Med blåtoner och krus: Ett kompendium om äldre folklig sång $i$ Sverige. [With Blue Notes and Ornaments: On Older Traditional Singing in Sweden.] Stockholm: Udda toner.

Ian Russell and David Atkinson, eds. Folk Song: Tradition, Revival, and Recreation. Elphinstone Institute Occasional Publications, 3. Aberdeen: University of Aberdeen.

Francesca R. Sborgi Lawson. "Rethinking the Orality-Literacy Paradigm in Musicology." Oral Tradition, 25:429-46. http://journal.oraltradition.org/issues/ 25ii/lawson

Mark Slobin. Subcultural Sounds: Micromusics of the West. Hanover, NH: Wesleyan University Press.

Britta Sweers. Electric Folk: The Changing Face of English Traditional Music. Oxford: Oxford University Press.

Gunnar Ternhag, ed. Samlade visor: Perspektiv på handskrivna visböcker. [Collected Songs: Perspectives on Handwritten Song Books.] Uppsala: Kungl. Gustav Adolfs Akademien för svensk folkkultur.

Thomas Turino. Music as Social Life. The Politics of Participation. Chicago: The University of Chicago Press.

Douglas C. Wadle. "Meaningful Scribbles: An Approach to Textual Analysis of Unconventional Musical Notations." Journal of Music and Meaning, 9. http:// jmm9.musicandmeaning.net 
Wallis and Malm 1984
Roger Wallis and Krister Malm. Big Sounds from Small Peoples: The Music Industry in Small Countries. London: Constable. 
Oral Tradition, 27/1 (2012): 85-108

\section{Masonic Song in Scotland: Folk Tunes and Community Katherine Campbell}

The Masonic song tradition of Scotland gives an opportunity to explore the vital role of oral tradition, particularly as carried by communal performance. Issues surrounding folk tunes and community will be explored in turn in this article, first by looking at the songs of Freemasonry against the backdrop of folksong culture and then by viewing the songs as central to the Masonic community and also more broadly to the community at large. This study builds on the general theoretical points made by Anne Dhu McLucas in the American context in her book, The Musical Ear: Oral Tradition in the USA. McLucas highlights the many musical contexts in which oral tradition plays a vital role, with the proposition that these contexts do "not depend on the use of musical notation to make their power felt" (2010:1). Of course, this does not mean that musical notation is not present, and McLucas recognizes that while "the oral/aural is present everywhere," it "mixes freely with the written" (4).

One of the main differences between oral societies and literate ones is that the oral, by definition, involves a group activity; one can read a story in a book alone and in silence, but a performer-audience dynamic must always be present in the oral environment. The importance of this communal context is discussed by McLucas (2010:132-33), who notes that the act of singing together forms strong bonds with fellow performers and brings the group closer together. Her examples include patriotic or nationalistic song, and she makes the following observations about a contemporary Rotary club in Oregon in which the singing is an adjunct to the overall activities of the group (129):

\footnotetext{
A group of middle-aged members of the Eugene Downtown chapter of Rotary International, male and female, gather every week for lunch at a local hotel. Part of the opening ceremony for this weekly luncheon is the singing of a national song - either the official anthem, which, though notoriously hard to sing, still comes up occasionally, or "America" or "God Bless America," the perennially favourite substitutes. With the help of a piano, they make a lusty sound, with harmonies - both accidental and intentional-occasionally appearing. Because it is part of their ritual, and because the group is meant to be participatory and collegial, all seem to take part.
}

The ritual nature of the event and the elements of participation and collegiality are also key to Masonic gatherings. This group context has more in common with the Masonic environment than McLucas's following example: that of song circles who meet with the express purpose of singing, where solo performance is heard in the main and where those assembled are expected to 
join in on the chorus. But all such groups involving singers have the face-to-face quality that gives scope for that difficult-to-define lift that has been called "presence." James Porter (2009:7-8) discusses this quality in the context of Scottish ballads, noting that the shared experience of a performance in a live situation is totally different from listening to a ballad though a mass-mediated channel (such as television, radio, or the Internet).

The community elements of folk music are much stronger than in the art music tradition. Take, for example, the classic definition of folk music, given by the International Folk Music Council in 1954 (Bohlman 1988:xiii):

Folk music is the product of a musical tradition that has evolved through the process of oral transmission. The factors that shape the tradition are: 1) continuity which links the present with the past; 2) variation which springs from the creative individual or the group; and 3) selection by the community, which determines the form or forms in which the music survives.

The term can be applied to music that has been evolved from rudimentary beginnings by a community uninfluenced by popular and art music, and it can likewise be applied to music which has originated with an individual composer and has subsequently been absorbed into the unwritten living tradition of a community.

The term does not cover composed popular music that has been taken over ready-made by a community and remains unchanged, for it is the re-fashioning and re-creation of the music by the community that gives it its folk character.

The word "community" is mentioned in each paragraph, sometimes more than once. The community is connected with the selection and preservation of material, with housing it in its "unwritten living tradition," and with re-creating it in terms of variation. In Anthony Seeger's study (1987) of the Suyá Indians of Brazil, music in combination with ritual is at the heart of community life, being used to mark out particular points in the day as well as in the calendar: in other words, music and community life are totally intertwined and are co-dependent.

In an oral culture, the music of a community is strongly linked with the concept of transmission. As Bruno Nettl observes (1982:3): "The way in which a tradition is passed on is called transmission, and the two terms are sometimes used, informally and perhaps colloquially, to emphasize two sides of the character of a culture or indeed of a music - its stability on the one hand, its tendency to change on the other."

The transmission of music includes both product and process. Bohlman refers to this combination in the context of oral tradition (1988:25):

The dialectic of oral tradition consists of both products and the processes by which these products are derived. For folk music, the product is the discrete entity - the song, the record of a single performance, a version of the unit of transmission - whereas the process is the continuation of transmission.

When transmission is discussed, it is more often associated with a group than with individuals in the case of an oral tradition (Bohlman 1988:71), but of course there are always individuals engaged in the process of passing things on as they make their own distinctive contributions. In 
the production of song, it is necessary to distinguish the two elements of words and music that may either keep together or take their separate ways. An important factor in transmission is the practice of contrafactum - the use of different words for an existing tune. The Latin word, meaning imitation or forgery, and used in relation to song since before the Middle Ages, is more familiar in a classical music context, but it is equally applicable to folk song. According to Grove's Dictionary, the practice "virtually disappeared in 19th- and 20th-century art music. This can be attributed to the premium placed on originality and the belief in the uniqueness of the individual work of art that has prevailed since the 19th century" (Falck and Picker 2012). The contrafactum principle has always been central to folk tradition where the use of the same tune over and over again is vital to its continuation - there is no premium placed on originality.

Tunes transmitted aurally are easily able to permeate cultures, to accompany song texts in different languages, to cross from folk song to other musical genres, and to cross from one socioeconomic context to another. Song has an especial importance in Scottish culture, and the relative simplicity of this musical form, coupled with the use of pre-existing tunes, has meant that there has been a continual outpouring of feelings by members of the community at large who had no technical musical skills. Typically, no need existed for song composers to develop new melodic material since there was so much fine music already "in the air" (as we know from the rich records we have from the seventeenth century onwards; see, for example, Stell 2008- and Johnson and Burns 1787-1803), and, equally typically, there has been no sense that the melodies as received were sacrosanct. The situation was indeed that of an aural culture as regards the music in the sense of the "taking in by ear of sounds" (McLucas 2010:1; see also Finnegan 1992:16), and the composers who received the music by ear accompanied by particular words transmitted it by mouth by singing fresh words to what would have been regarded as "the same" music that would always have been subject to modification in the light of the different words and the composer's skills and preferences. These musical vehicles were open to Masons in Scotland as well as to the community as a whole.

\section{Masonic Tunes}

It is often the case that the creation of a group's identity is achieved partly through its songs. This was certainly true for the Masons, where song played an important role from the time of the Craft's formalization in the early eighteenth century, and song was also likely involved even in the informal freemasonry that is known to have taken place earlier in Scotland within taverns and the like and in the convivial activities that accompanied proceedings. In general, two types of song can be observed: formal songs dealing with the history of Freemasonry, its principles, and so on, sometimes of an anthem-like nature, and more informal material of a drinking song variety.

While these two types of Masonic song might be thought of as examples of art song on the one hand and of folk song on the other, Matthew Gelbart cautions against this response, and demonstrates that it was only in the late eighteenth century that the categories of folk and art music actually emerged or, to use his term, were "invented," due to the "transfer of emphasis from function to origin" (2007:15). Thinking of function here, we have different kinds of 
material for the formal and informal points in the Masonic ceremony, with the former being more dependent on musical literacy and musical training than the latter.

Although Scotland played an important part in the foundation of Freemasonry (Stevenson 1988), its formal organization began in England and a central text, The Constitutions of the FreeMasons, was published in London in 1723. The work was by James Anderson (1679-1739), who was born in Aberdeen and was the son of the former secretary of the Lodge of Aberdeen (Stevenson 1987:39). The Constitutions includes four songs. The first three of these are of the formal type: "The Master's Song: Or, the History of Masonry," "The Warden's Song: Or, Another History of Masonry," and "The Fellow-Crafts Song." The fourth, "The Enter'd Prentice's Song," is of the informal type that relates to folk song. To show the extent of the contrast between types, the tunes of two of the three formal songs are considered here (the tune of the "Fellow-Crafts Song" is not included in Anderson 1723) and then compared to "The Enter'd Prentice's Song."

In the first edition, "The Master's Song" is a long and formal affair with 28 eight-line verses with a four-line chorus to be sung at the behest of the Master, and pauses at the ends of Parts 1-4 in order to drink firstly the present grand-master's health, then to drink to the health of the "Master and Wardens of this particular Lodge," then "to drink to the glorious Memory of Emperors, Kings, Princes, Nobles, Gentry, Clergy, and learned Scholars, that ever propagated the Art," and finally "to drink to the happy Memory of all the Revivers of the ancient Augustan Style" (Anderson 1723:75-78). In the revised edition of 1738, however, the song has been reduced to six verses with chorus and carries the explanatory note: "In the first Book it is in 5 Parts, comprehending the History of Masonry; but being too long, the $3 \mathrm{~d}$ Part is only printed here" (Anderson 1738:200). It seems likely that this contraction of the text came from the response of the performers of the song, emphasizing the difference between a song in print and its transformation into a song in performance. Since music does not appear in the 1738 volume, the 1723 illustration of "One Verse of the Third Part of the Master's Song, with the Chorus, set to Music, by a Brother" is given here (Anderson 1723:85-86): 
( 85 )

One Verfe of the Third Part of the Mafter's Song, with the Chorus, fet to Mufic, by a Brother.
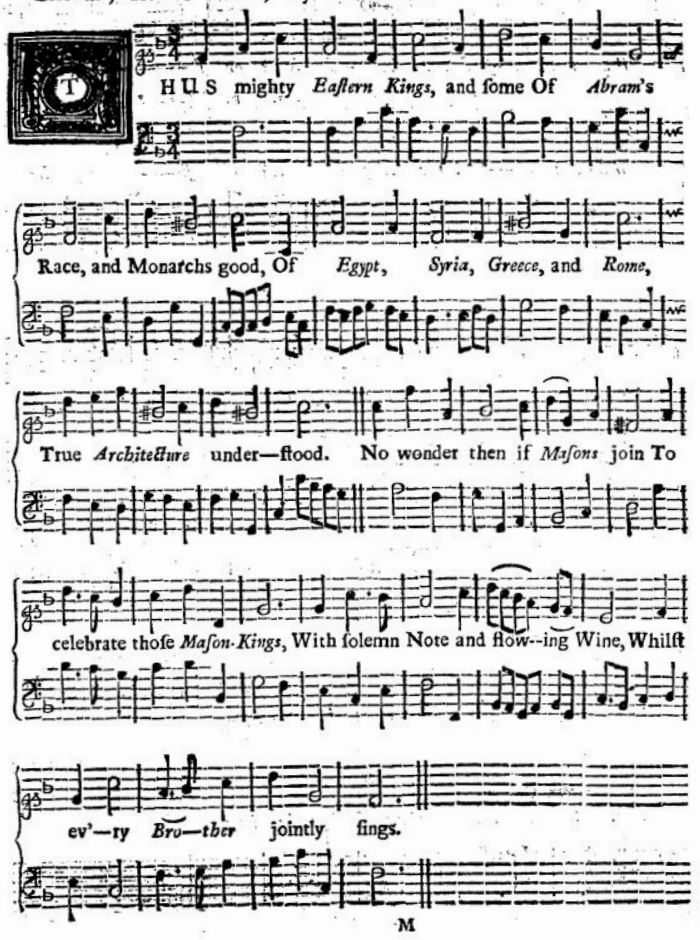

( 86 )
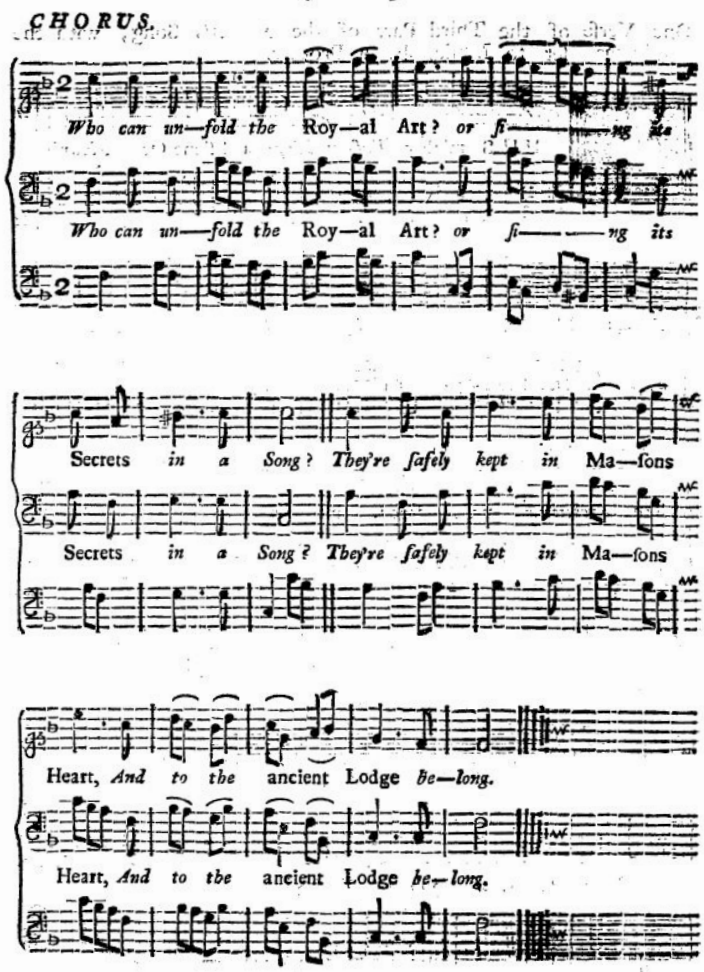

Fig. 1: “The Master's Song.” Eighteenth Century Collections Online, http://www.jisc-content.ac.uk/collections/ eighteenth-century-collections-online-ecco.

Thus mighty Eastern Kings,

and some Of Abram's Race, and Monarchs good,

Of Egypt, Syria, Greece, and Rome,

True Architecture understood.

No wonder then if Masons join

To celebrate those Mason-Kings,

With solemn Note and flowing Wine,

Whilst ev'ry Brother jointly sings.

\section{Chorus}

Who can unfold the Royal Art?

or sing its Secrets in a Song?

They're safely kept in Masons Heart,

And to the ancient Lodge belong.

Regarding the tune, we may well be seeing the Masonic significance of the number three since the song is in three parts, demarcated by double bar-lines reflecting the eight-line verse (itself in two parts) and the four-line chorus. The eight-line text is split into two different pieces, melodically speaking, so that we have an $\mathrm{ABC}$ structure overall (including the chorus). A bass 
line is given for the verse, but then the music for the chorus is a three-part treatment, harmonically speaking, with the melody, a harmony line, and a bass line being given. The key signature of the tune is $\mathrm{F}$ major, but the tune modulates at various points to encompass $\mathrm{C}$ major and briefly $\mathrm{G}$ minor; three keys can thus be detected. The first two parts are in 3/4 time. Part 1 of the tune is 16 bars in length but Part 2 has 15 bars, an unusual feature possibly linked to the Masonic significance of the numbers three and five (Mackey 1929). Within Part 2, the first phrase is only seven bars in length up to the word "Kings," and then the second phrase occupies eight bars. The seven bar phrase can be accounted for by the unexpected treatment of "celebrate those Mason-Kings," which one would expect to occupy four bars but here occupies only three. Part 3 - the chorus - is in 2/4 time and is 16 bars in length. The chorus is concentrated in the higher tonal register, but the melody of the tune overall has a wide range from middle $\mathrm{C}$ up to $\mathrm{G}$ directly above the staff of the treble clef — an octave and a fifth — which would have been sung an octave lower by male voices.

In the case of "The Warden's Song," we again see striking textual contraction. The note to it in the 1738 edition appears to show a flexible responsiveness to performance of this rather stiff and lengthy piece with its elaborate chorus. "In the first Book [that is, the 1723 edition] it was of 13 Verses, too long: But this last Verse and Chorus is thought enough to be sung" (Anderson 1738:202). The last verse and chorus mirror what is presented with the music in the 1723 edition, and the first two pages of this earlier edition's music are reproduced here along with the corresponding text (Anderson 1723:87-90):
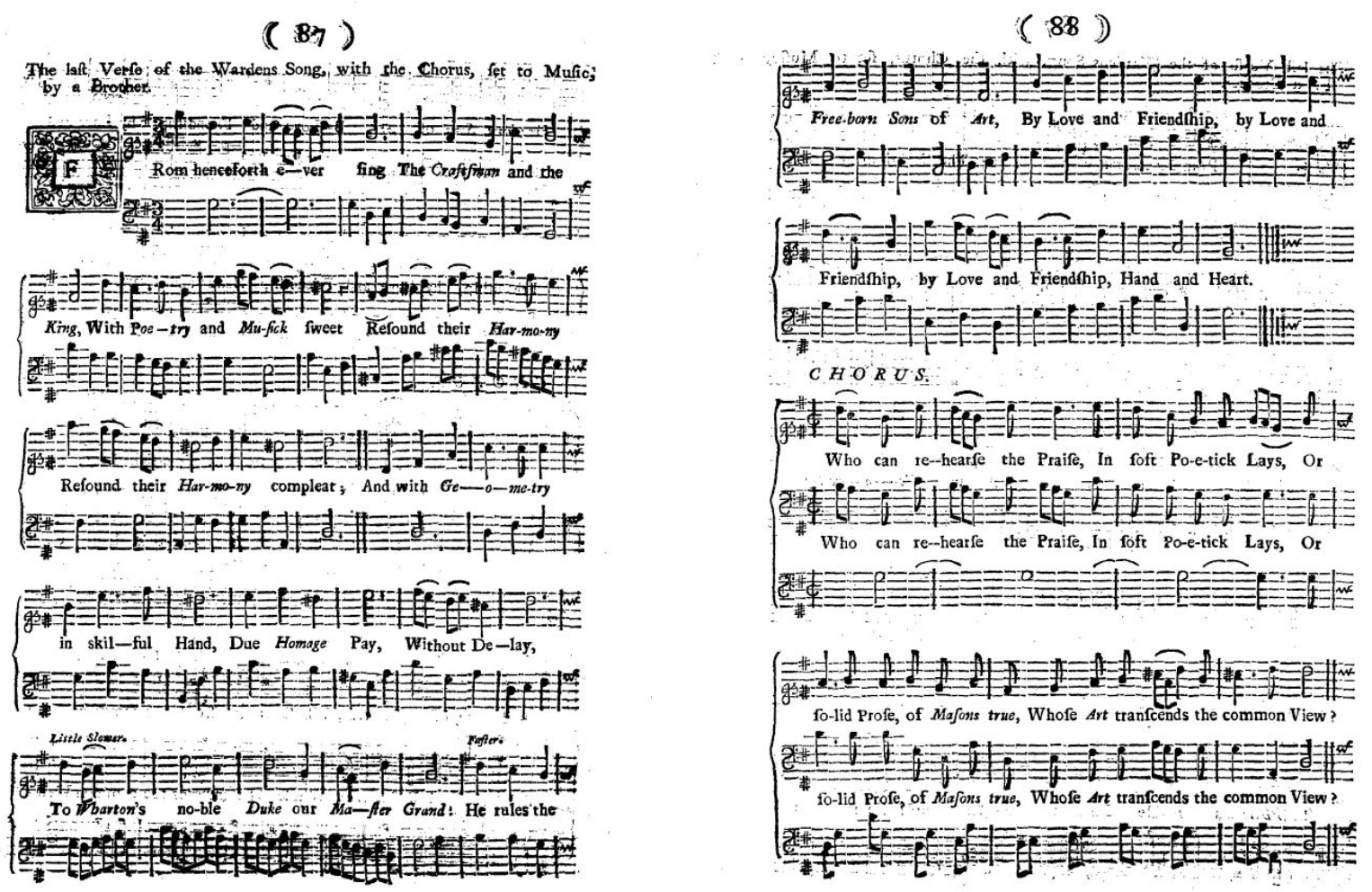

Fig. 2: "The Warden's Song," (Anderson 1723:87-88). Eighteenth Century Collections Online, http://www.jisccontent.ac.uk/collections/eighteenth-century-collections-online-ecco. 
From henceforth ever sing
The Craftsman and the King,
With Poetry and Musick sweet
Resound their Harmony
Resound their Harmony compleat;
And with Geometry in skilful Hand,
Due Homage Pay, Without Delay,
To Wharton's noble Duke our Master Grand; ${ }^{1}$
He rules the Freeborn Sons of Art,
By Love and Friendship, By Love and Friendship,
by Love and Friendship, Hand and Heart.

Chorus

Who can rehearse the Praise

In soft Poetick Lays,

Or solid Prose, of Masons true,

Whose Art transcends the common View?

Their Secrets, ne'er to Strangers yet expos'd,

Preserv'd shall be Preserv'd shall be, by Masons Free,

And only to the ancient Lodge disclos'd;

Because they're kept in Mason's Heart, because they're kept in Mason's Heart

by Brethren of the Royal Art.

In terms of the tune of "The Warden's Song," we have a similar pattern of a three-part melody (ABC). We have 15 bars in Part 1, and then Part 2 in 3/4 time has 25 bars. In Part 2 the tune is marked a "Little slower" at "To Wharton's noble Duke our Master Grand," then "Faster" at "He rules the Freeborn Sons of Art, By Love and Friendship ..." when the song resumes, this change in tempo presumably being made in order to honor the Grand Master. The chorus in 2/2 time has a two-beat anacrusis, then five bars followed by a double bar-line, and then a further nine bars to finish. This arrangement may well again relate to the importance of the numbers five and three. The chorus splits into two parts with a bass line (three lines in total). We have the musical device of canon in the chorus (1723:89), where the harmony part starts a little later than the melody but with the same words. The overall key of the piece is $\mathrm{G}$ major, but three keys can be detected: $\mathrm{G}$ major, D major, and brief movement to E minor. The range is an octave and a fifth.

"The Enter'd Prentice's Song" is a much simpler affair by comparison. It is eight bars in length in the key of $\mathrm{C}$ major with a 6/4 time signature, and it can be broken down into two simple phrases, each of four bars in length. There is no harmonization or bass line and the melody is simple. The song is short and easily memorable, especially compared to the two pieces just discussed, and the tune has the range of a ninth (Anderson 1723:84 [lyrics], 90 [music]):

${ }^{1}$ The name Wharton is brought up-to-date by replacement with "Caernarvon" in the 1738 edition. 


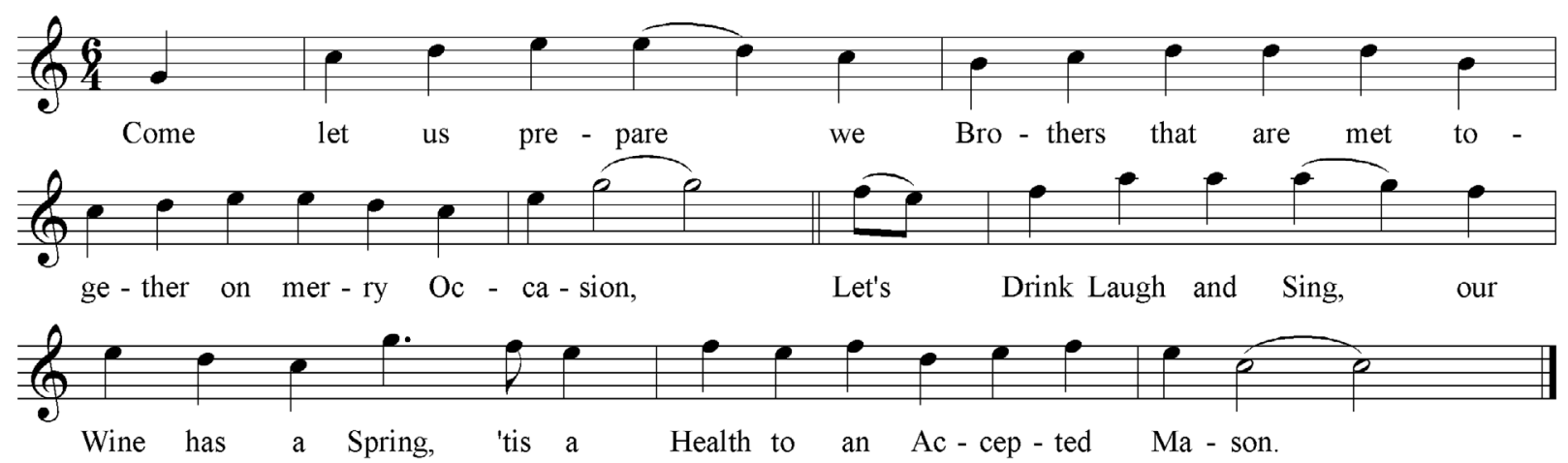

Fig. 3: "The Enter'd Prentice's Song."

1) Come let us prepare

we Brothers that are met

together on merry Occasion,

Let's Drink Laugh and Sing,

our Wine has a Spring,

'tis a Health to an Accepted Mason. ${ }^{2}$

2) The World is in pain

Our Secrets to gain,

And still let them wonder and gaze on;

They ne'er can divine

The Word or the Sign

Of a Free and an Accepted Mason.

3) 'Tis This, and 'tis That,

They cannot tell What,

Why so many Great Men of the Nation

Should Aprons put on,

To make themselves one

With a Free and an Accepted Mason.

4) Great Kings, Dukes and Lords,

Have laid by their Swords,

Our Myst'ry to put a good Grace on,

And ne'er been asham'd

To hear themselves nam'd

With a Free and an Accepted Mason.

5) Antiquity's Pride

We have on our side,

2 The text of the first verse is given here as it appears with the music. On p. 84, where the whole text is given, the words differ slightly, namely "are Assembled" for "are met together" and "Here's" for "'tis" in the last line. 
And it maketh Men just in their Station:

There's nought but what's good

To be understood

By a Free and an Accepted Mason.

6) Then join Hand in Hand,

T'each other firm stand,

Let's be merry, and put a bright Face on:

What Mortal can boast

So Noble a Toast,

As a Free and an Accepted Mason?

Overall, this is a more relaxed piece as reflected in the indication regarding its performance; it is to be "sung when all grave Business is over, and with the Master's Leave" (Anderson 1723:84). The last verse indicates a toast. The tune is said to have been composed by Brother Matthew Birkhead (90), yet a version of it appeared earlier in Pills to Purge Melancholy in 1719 (Chappell 1855-59:ii, 663). Although it is possible that Birkhead did write the tune since he was a singer, composer, and actor at Drury Lane Theatre in London (Denslow and Truman 1957:i, 97), Birkhead had died by the time of Anderson's publication, and it is equally possible that the tune to which his words are set was in fact drawn from earlier tradition.

It was only after a song's composition that a tune could potentially be considered to have Masonic links and thus take on extra-musical associations when used with other sets of words. Later in the eighteenth century, Robert Burns used with good effect the tune of "The Enter'd Prentice's Song," setting his "No Churchman Am I for to Rail and to Write" to it in 1782. He entitled the tune "Prepare, my dear Brethren, to the tavern let's fly," suggesting that there was perhaps a comic Freemason drinking song known to him that went to this same tune. Burns's song, in fact, is little more than a drinking song with its emphasis in the last line of each verse on a bottle of wine. The last verse, "A Stanza added in a Mason Lodge," runs (Kinsley 1968:i, 39):

\footnotetext{
Then fill up a bumper and make it o'erflow, And honours masonic prepare for to throw;

May ev'ry true Brother of th' Compass and Square

Have a big-belly'd bottle when harass'd with care.
}

Andrews (2004:280) makes the point that drunkenness was not actually tolerated, with Masons being fined if they became intoxicated, but that conviviality was an important part of gatherings.

Similarly, Burns's "Farewell to the Brethren of St. James Lodge, Tarbolton" uses the folk tune of "Guid Nicht and Joy be Wi you Aa'," the traditional parting song of Scotland before "Auld Lang Syne." Here he builds on the idea that everyone knew that this was a song of parting, and he personalizes it to make it into his own leaving song, using the first person ("Tho I to foreign lands must hie"). He also peppers it with language typically found in Masonic songs, such as "hieroglyphic bright," "grand design," "Architect Divine," "Order," and "Masonry": the song thus operates on many levels and is more like the formal type of Masonic anthem, rather 
than being a drinking ditty. Although Burns only wrote a few Masonic songs, being drawn more toward the idea of comradeship on a grander scale later on in his life (Andrews 2004:304), the concept of the anthem is one that permeates a number of his songs, the most famous of which are "Auld Lang Syne" and "A Man's a Man for aa That." These are songs that are still sung today, the former uniting peoples of the world at the turn from the old year to the new one. The opening of his song of brotherhood to the earlier tune of "Guid Nicht and Joy" runs as follows (Dick 1903:214-15):

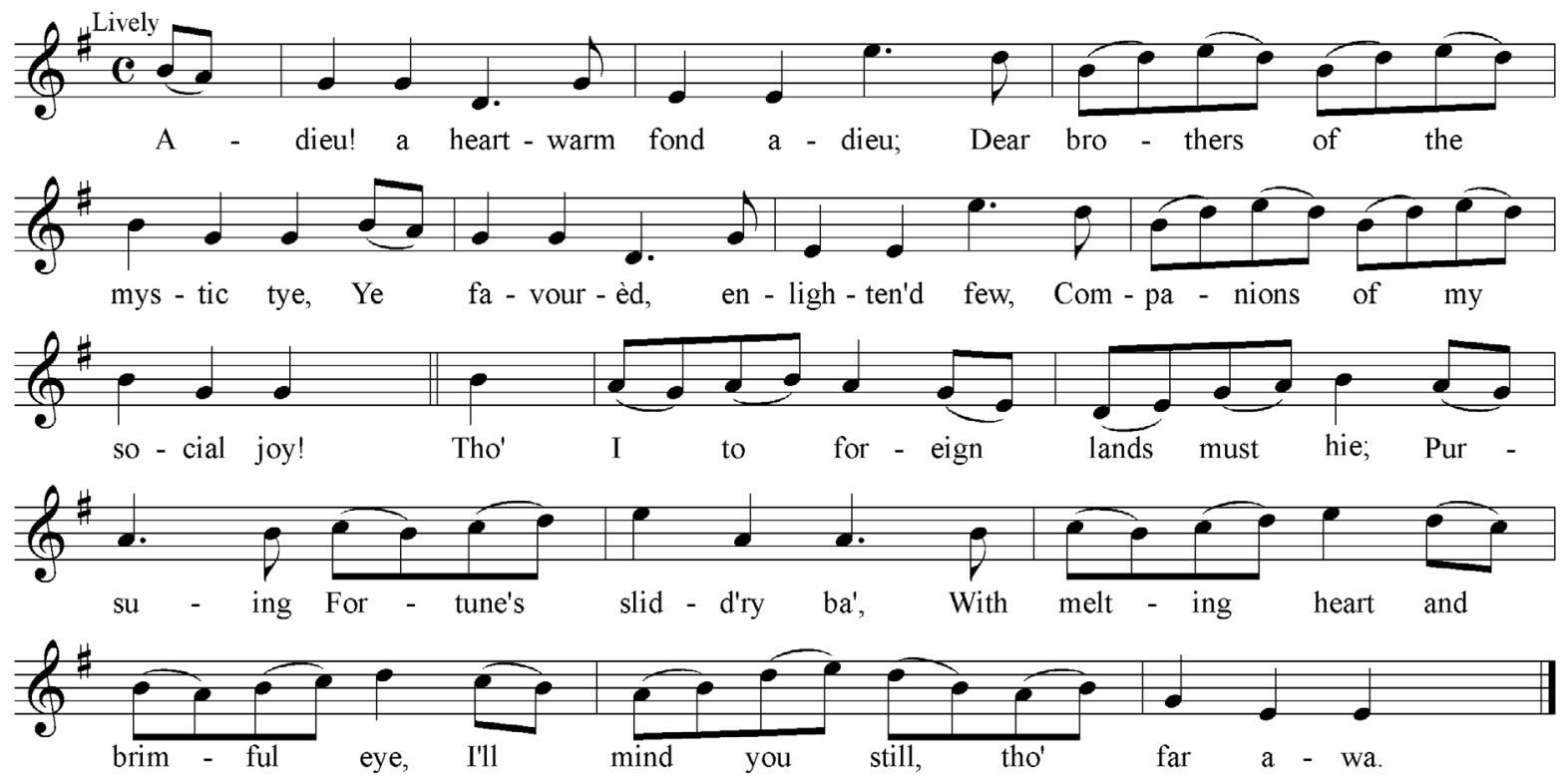

Fig. 4: "Farewell to the Brethren at St. James Lodge, Tarbolton."

1) Adieu! a heart-warm, fond adieu;

Dear brothers of the mystic tye,

Ye favoured, enlighten'd few,

Companions of my social joy!

Tho' I to foreign lands must hie,

Pursuing Fortune's slidd'ry ba';

With melting heart and brimful eye,

I'll mind you still, tho' far awa.

2) Oft have I met your social band,

And spent the cheerful, festive night;

Oft, honour'd with supreme command,

Presided o'er the sons of light:

And by that hieroglyphic bright,

Which none but craftsmen ever saw!

Strong Mem'ry on my heart shall write

Those happy scenes, when far awa!

${ }^{3}$ The song has four verses in total. 
The tune of "Guid Nicht and Joy" seems to have become associated with being a Masonic tune after Burns's use of it. A song called "Come, All Ye Freemasons" was written down by the fiddler and collector, George Riddell of Rosehearty (1853-1942), who was Right Worshipful Master of Lodge Forbes in his village. He states that the song "was known only to "brothers of the mystic tie"” (making reference to Burns's song lyric) and continues (Riddell 1906-11:118):

I have heard it sung with great applause on high and memorable occasions; but my recollection of the words is of the haziest description. The very few who knew it have long since ascended to the Grand Lodge above, and it is only after infinite trouble that I have managed to give the first verse. Indeed, the seventh line is an interpolation of my own, done for the purpose of showing the run of the melody. The song, although of interest to members of the craft, was of no poetic merit; but I think the melody worthy of preservation.

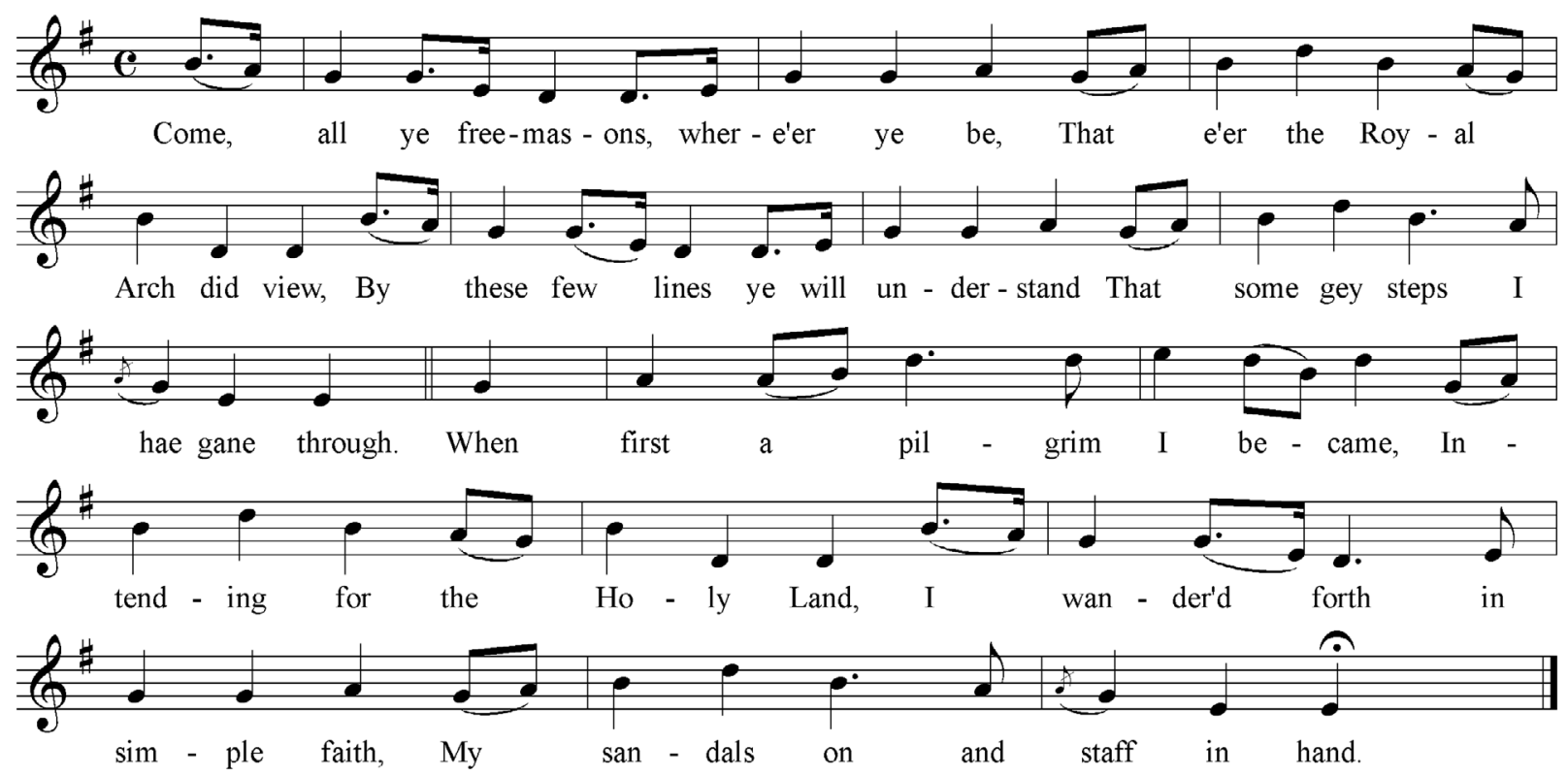

Fig. 5: "Come All Ye Freemasons” (Riddell 1906-11:118).

Come, all ye freemasons, where'er ye be,

That e'er the Royal Arch did view,

By these few lines ye will understand

That some gey steps I hae gane through.

When first a pilgrim I became,

Intending for the Holy Land,

I wander'd forth in simple faith,

My sandals on and staff in hand.

Although not identical to the tune of "Guid Night," this song can certainly be considered a variant of it. It is of the same length (16 bars) and is in two parts. It opens in a very similar fashion and closes in an almost identical way. When the opening phrase is repeated again beginning in bar 4, we see the same pattern in Riddell's tune. The opening of the second part in 
"Guid Night" (B A G A B) is similar to the equivalent point in Riddell's tune (G A A B D). Riddell's tune differs in form to that of "Guid Night" (A Av B Av instead of A Av B C), ${ }^{4}$ but this variance can perhaps be linked to the general traits of the folk process, where repetition is key and where more complex musical phrases (that is, "C") tend to get simplified.

Folk tunes that we can be fairly certain had no particular Masonic connection were also adopted for the songs. There are examples in The Musical Mason or Free Mason's Pocket Companion (c. 1764-78) where tunes are given in staff notation or the melodies are named at the top of the page. These songs include "Some folks have with curious impertinence" (set to "Greensleeves"), "King Solomon that wise Protector" (to "Come Fy Let Us aa to the wedding"), "How happy a mason whose bosom still flows" (to the jig "the Miller of Mansfield"), and "With Cordial Hearts let's drink a Health" (to "the Wark o the weavers"). The use of folk tunes would have made the songs accessible to people, whether or not they could read staff music notation. To people already familiar with the tunes in an oral context, this method offered the chance for immediate performance.

We also have examples of Masonic songs in the books where no tune title is given, and this again is a hallmark traditionally of the printing of folksong in Scotland. In these instances the implication is either that everyone knew what the tune was and did not need to be told its title or more likely, I think, that people could simply draw on any tune they knew that fitted the words. An example here is "While Yet as a Cowan" 5 from St Cecilia; or, the British Songster, published in Edinburgh in 1782, a song that has a distinctive stanza pattern that suggests knowledge of the well-known "A'body's Like to be Marriet but me" (Greig-Duncan 1374). ${ }^{6}$ The Masonic song gives a humorous treatment of the transition from the outside world where Freemasonry could be regarded as devil's work ${ }^{7}$ to incorporation into the first stage of the Masons' world (tune: Greig-Duncan 1374C; ${ }^{8}$ text: St Cecilia 1782:no. 3):

\footnotetext{
${ }^{4}$ In this notation, " $\mathrm{v"}$ indicates a variant in the musical phrase.

${ }^{5} \mathrm{~A}$ cowan is an unskilled laborer.

${ }^{6}$ Greig-Duncan references are taken from Shuldham-Shaw et al. 1981-2002.

${ }^{7}$ Roeck (1995) has explored this theme in Belgium and the Netherlands.

${ }^{8}$ The tonic has been lowered here from $\mathrm{D}$ to $\mathrm{C}$.
} 


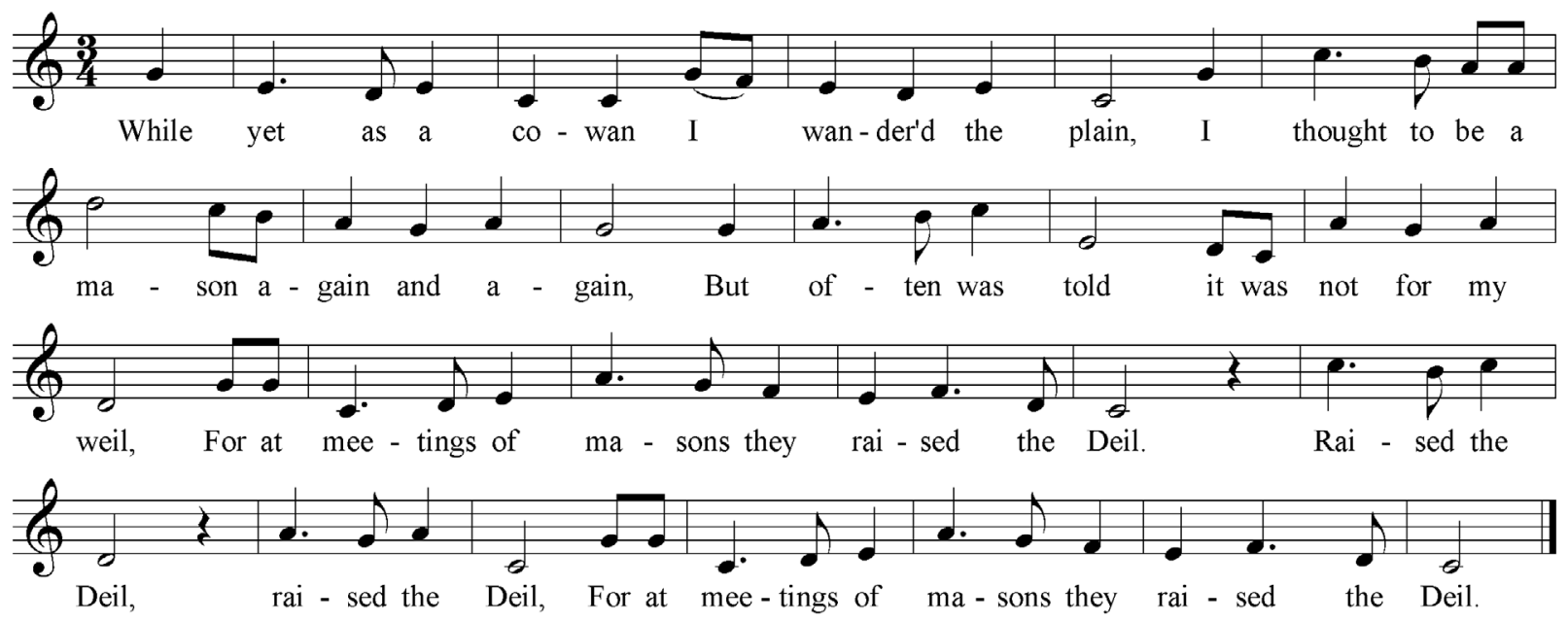

Fig. 6: "While Yet as a Cowan."

While yet as a cowan I wander'd the plain,

I thought to be a mason again and again,

But often was told it was not for my weil,

For at meetings of masons they raised the Deil.

raised the Deil, \&c.

I thither repair'd, being resolv'd in my mind,

When to my surprise a good friend I did find,

And bade me prepare, for so hearty I'd feel,

What still was now strange when I thought on the Deil.

thought on the Deil, \&c.

We knock'd, but was stopp'd; when we enter'd the door,

They said, Who bring you here whom we ne'er saw before;

I told them I thought to be admitted fu' weil,

As I freely came here to shake hands wi' the Deil.

shake hands wi' the Deil, \&c.

By leave from the chair then admittance we found,

But like one that's blind I gropp'd all the way round;

'Till something I felt made me stagger and reel,

Which rais'd my old thought, I'd meet wi' the Deil.

meet with the Deil, \&c.

At last to my joy I found all things go right

And began by degrees to discover the light;

The master advis'd me to swallow a pill,

Which he said would purge me from all fears of the Deil.

fears of the Deil, \&c. 
By leave from the chair I did join the glad throng,

And partook of their joys o'er a glass and a song,

Ye cowans, remember the masons are leel,

And beware of yourselves when you speak of the Deil.

speak of the Deil, \&c.

Two other Masonic items are found in St Cecilia, one set to the tune of "God Save the King." It is clear that such material circulated freely and was not limited to books of Masonic song per se. Indeed, the songs seem to have enjoyed wide popularity, and there was a market for them. This last point is borne out by the appearance of Masonic songs on broadsides - cheap, ephemeral, one-sheet publications that were common throughout Britain. An example is "The Sons of Levi," which emanated from the Poet's Box in Glasgow (see further McNaughtan 1990:173-75) and was published in 1874. This song also occurs in the Greig-Duncan Folk Song Collection, made in the early twentieth century by Gavin Greig and James Bruce Duncan in the Northeast of Scotland, that contains several other Masonic songs, some in different versions. One simply called "Freemasons' Song," which was contributed by James Angus, a cooper from Peterhead, opens with the following verse (Greig-Duncan 466):

\footnotetext{
Behold in a Lodge we dear brethren are met, And in proper order together are set;

Our secrets to none but ourselves shall be known,

Our actions to none but Freemasons be shown,

Derry down down, down derry down.
}

This song stresses the concept of a secret world, and Greig alluded to these recondite activities when he published the material: "Not being myself a member of the craft I am not in a position to remark on the songs submitted" (Greig 1963:Ob. 155). ${ }^{9}$ However, the songs themselves were in many cases an open secret. As well as being freely published, they must have been heard sung by Masons either in private or on public occasions. Although women were excluded from the Masonic brotherhood, two Masonic items in the Greig-Duncan collection provide evidence that songs did cross the gender division. "The Plumb and Level" (472) and "The Freemason King" (467) were contributed by Mrs. Johnstone of Bogie near Huntly who recalled them from the singing of her father who was a Mason. Clearly, this singing must have taken place outside a Masonic lodge in order for her to recall the material. It is possible that these types of songs were in women's passive repertoires rather than their active ones (see Russell 1986), and it was perhaps seen as inappropriate for women to sing these songs to an audience. At any rate, this kind of transmission seems to fall into the general category of material sung in the home being absorbed by women, even though they were not necessarily the performers.

The tunes of the Masonic songs in Greig-Duncan are either tunes specifically associated with Freemasonry or folk tunes. In the case of the "Sons of Levi" (470), Greig makes the volume.

9 “Ob." relates to the series of articles originally published in The Buchan Observer given in the 1963 
interesting comment that the tune is called "The Mason's Word-Keep your mouth shut" (Greig 1963:Ob. 155). The tune itself is not given in Greig-Duncan, but it does occur in the contemporary collection of Cecil Sharp from England, and that tune has been used here with minor modifications (Karpeles 1974:ii, 489):

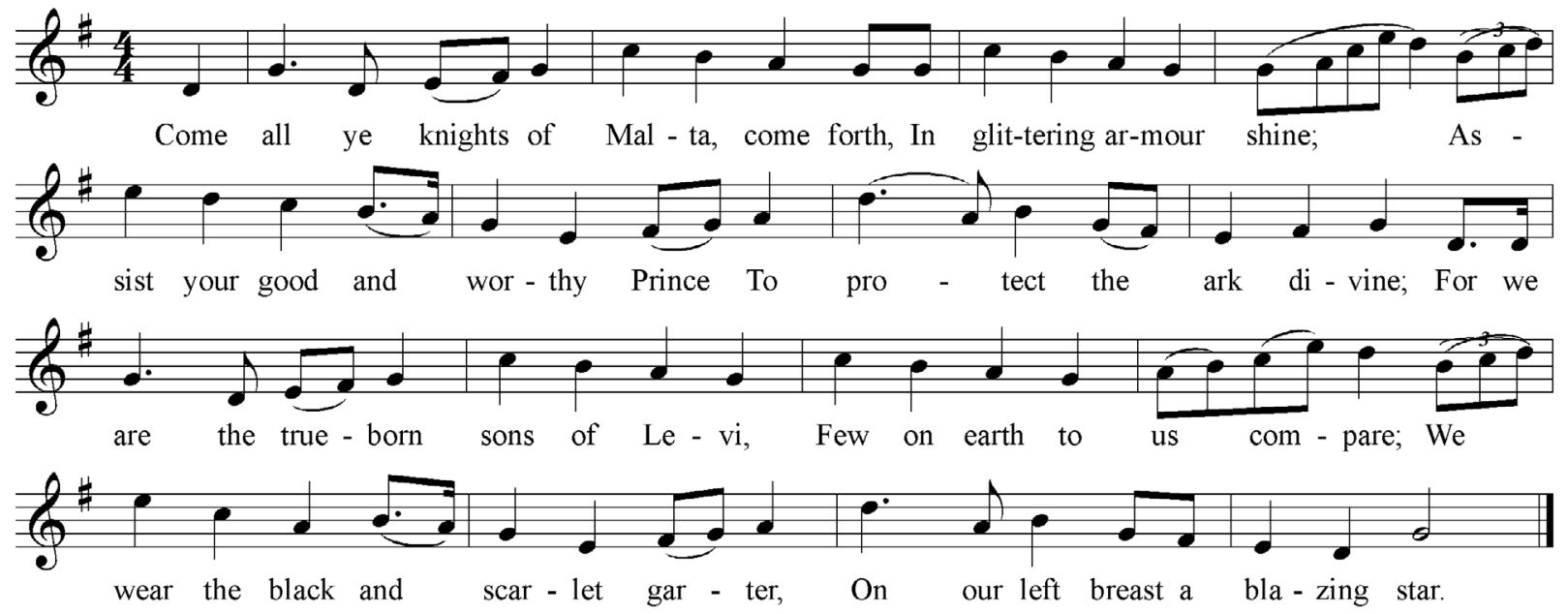

Fig. 7: "Sons of Levi."

1) Come all ye knights of Malta, come forth,

In glittering armour shine;

Assist your good and worthy Prince

To protect the ark divine;

For we are the true-born sons of Levi,

Few on earth to us compare;

We wear the black and scarlet garter

On our left breast a blazing star.

2) With trembling steps I slow advanced,

Sometimes I knocked both loud and shrill,

Until a knight in armour bright

Demanded me what was my will.

Sharp's version was collected from the singing of James Beale (aged 72) at Warehorne in Kent in 1908 (Karpeles 1974:ii, 489).

"The Freemason King" (467) uses a folk tune that appears in variants under a number of titles, including "Allan MacLean" (1403) and "Donald's Return to Glencoe" (1044). William Christie notes that this same tune — which he calls "The Rose of Dundee" (1876-81:ii, 274) —was used in Morayshire for this song that he refers to as "a long masonic ballad, "The building of Solomon's Temple'." The tune of "Wi the Apron On" was recorded by George Riddell of Rosehearty (Greig-Duncan 471D) as one used for the annual Masonic procession there (see below). Riddell's tune is given in Figure 8. The four tunes for this song in Greig-Duncan closely resemble one another, all being in 6/8 time, with some having a simplification of the second part 
presented in Riddell's tune, or simply a repetition of the first part for the refrain. The close melodic correspondence overall tells us that only one tune was being used for this song. The tune bears similarities to that of Greig-Duncan 1088, "Irish Mally O," and thus seems to have been used for a range of songs, one of them being this Masonic one.

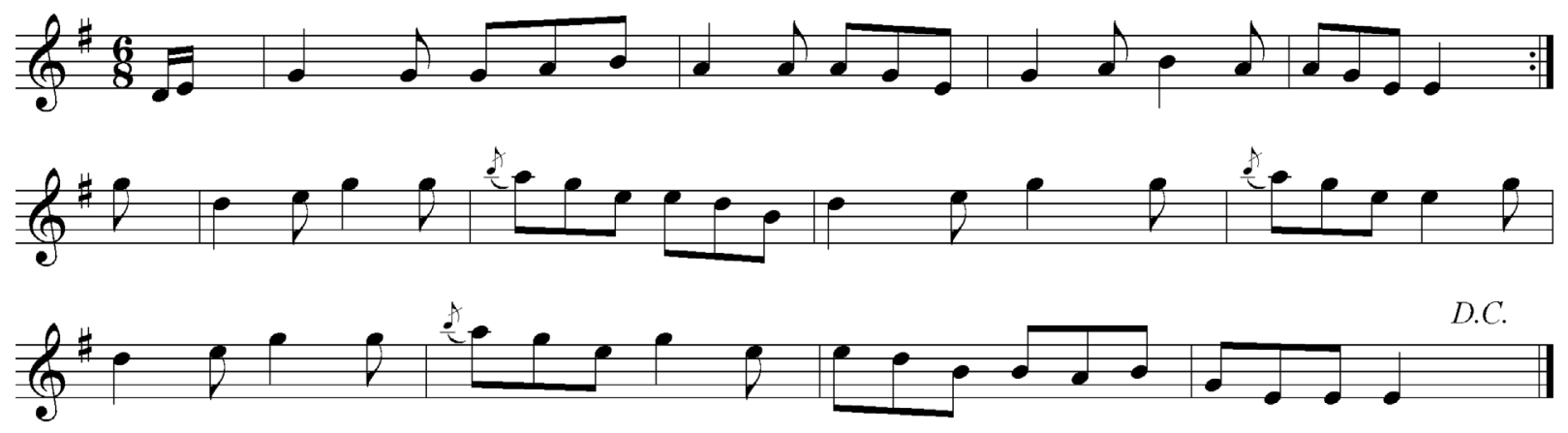

Fig. 8: "Wi the Apron On" (Greig-Duncan 471D).

\section{Masonic Song and Community}

Within the Lodges, the Masons had the expectation of singing songs at regular meetings with each other in a ritualized face-to-face community, in an all-male environment. The songs included choruses where everyone could join in, and these often contained the plural "we" in their lyrics, as in "We are the true born sons of Levi." The songs helped to pledge allegiance to the group. Clark believes that the production of Masonic songbooks resulted in "a kind of musical lingua franca, [which] facilitated the participation of visitors at lodge meetings" (2000:326). The Masons were further surrounded by objects in the Lodges that could be understood on two levels: the concrete in the case of operative masonry and the symbolic in the case of speculative freemasonry. (See further MacNulty 1991.)

Instrumental music was also sometimes heard and was held in high regard; indeed some Lodges had a specific place-the Musicians' Gallery (sometimes called the "Fiddlers' Gallery") — for this. An example can be seen in Fig. 9, a photograph from Lodge St. Ebbe ${ }^{10}$ in the fishing port of Eyemouth, not far from the

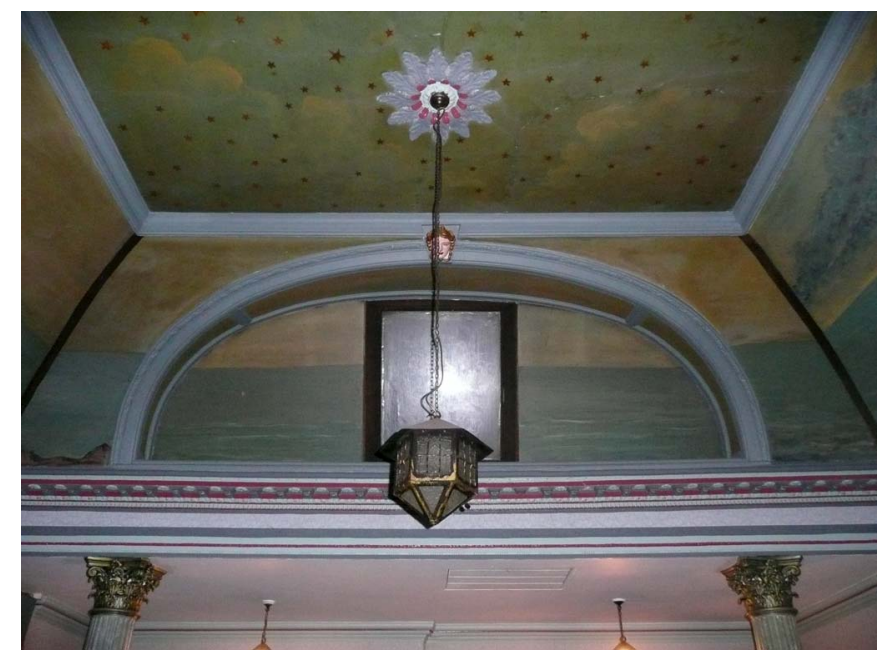

Fig. 9: Fiddlers' Gallery, Eyemouth.

10 I would like to thank the late Mrs. Jean Hutchings, a Ph.D. student at Celtic and Scottish Studies, University of Edinburgh, for introducing me to Mr. Jack Willox of Lodge St. Ebbe who kindly supplied this photograph of the Lodge interior. 
border between Scotland and England. The Gallery is above the place where meetings were held and was accessed by a ladder.

Masons did venture outside the ritualized space of the Lodge and into the wider community on special occasions and at certain, specific times of year, and here again music was central. The engraving by David Octavius Hill (Fig. 10) of the St. James's Masonic Lodge march of 1840, for

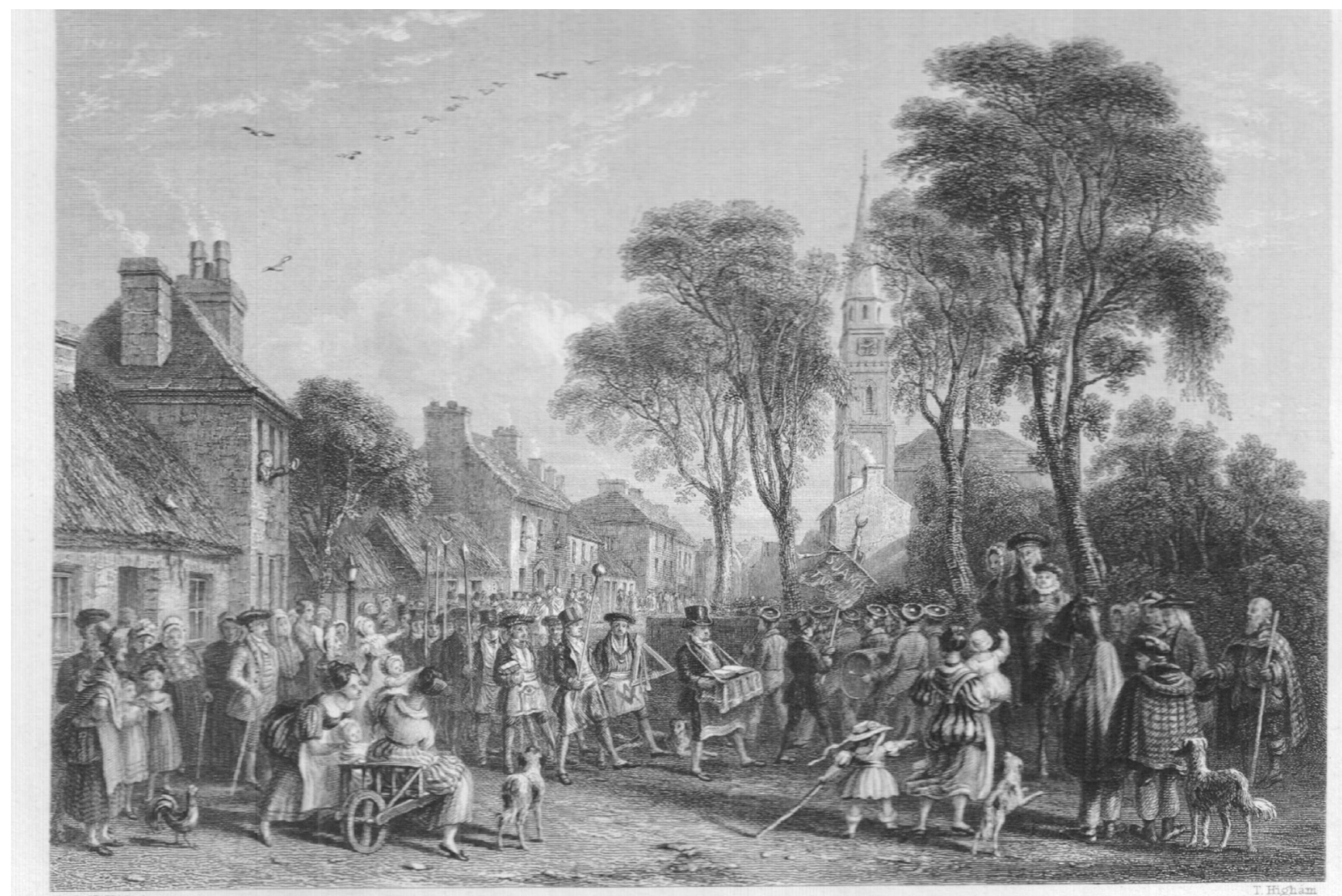

Fig. 10: Masonic procession (Wilson and Chambers 1840:66).

example, shows a band of music-makers. Particular times for gathering were Sts. John Days, as Jones notes (1956:339): "Many ancient lodges had their summer festival on St John the Baptist's Day [June 24] and their winter festival on St John the Evangelist's Day, December 27." Wade's history of Melrose speaks of a procession held at the winter festival time (1861:145-47): 
Immediately after the election of office-bearers for the year ensuing, the brethren walk in procession three times round the Cross, and afterwards dine together, under the presidency of the newly elected Grand Master. About six in the evening the members again turn out, and form into line two abreast, each bearing a lighted flambeau, and decorated with their peculiar emblems and insignia. Headed by the heraldic banners of the lodge, the procession follows the same route, three times round the Cross, and then proceeds to the Abbey. On these occasions the crowded streets present a scene of the most animated description. The joyous strains of a well-conducted band, the waving torches, and incessant showers of fireworks make the scene a carnival. But at this time, the venerable Abbey is the chief point of attraction and resort, and as the mystic torch-bearers thread their way through its mouldering aisles, and round its massive pillars, the outlines of its gorgeous ruins become singularly illuminated, and brought into bold and striking relief. . . . The whole extent of the Abbey is, with "measured step and slow," gone three times round. But when, near the "finale," the whole masonic body gather to the chancel, and forming one grand semicircle around it, where the heart of King Robert the Bruce lies deposited near the High Altar, and the band strikes up the patriotic air,

"Scots wha hae wi' Wallace bled,

Scots wham Bruce has often led,"

the effect produced by the associations of the music and the scene is sublime and overpowering.

Midst showers of rockets and the glare of blue lights, the scene closes.

"Scots Wha Hae" (Low 1993:no. 246) was central to the closing sequence of the proceedings and would have been a tune (and song) that was known to everyone in the community as part of their cultural memory. It continues to have such impact and indeed was put forward as one of the tunes that might be adopted as the Scottish national anthem following the inauguration of the Scottish Parliament in recent times.

A representation of a recent Masonic procession in Melrose is captured in a DVD produced by Moffat (2008). Here a pipe band provides the music, and an extended version of the "Ho Ro the Merry Masons" tune (discussed below) is used at the start and played repeatedly. This tune is a variant of "The Enter'd Prentice's Song," although inevitably it is given in a different form than that which appears in Anderson. Its range of a ninth - the same as that of the Highland bagpipe-makes the tune eminently suited to that instrument. The repeated use of the melodic motif " $\mathrm{G} \mathrm{A}^{\mathrm{b}} \mathrm{G} \mathrm{F} \mathrm{B}$ " corresponding to the words "as we march along" is particularly noticeable. Other tunes used for the march include favorites such as "Scotland the Brave" and "The Rowan Tree." A soloist is heard singing "Scots Wha Hae" in the Abbey itself. A lone piper plays "Flowers of the Forest," the solemn tune used for funeral processions in Scotland. Then group singing of "Auld Lang Syne," not accompanied by pipes, is heard.

A Masonic procession, or "Walk," also takes place in the coastal village of Rosehearty in Northeast Scotland (Campbell 2008b) during the afternoon on the second day of January. It lasts around two and a half hours and involves the Masons processing along the streets of the village in their regalia, cheered by onlookers. Newly initiated Masons carry the flags of Lodge Forbes, and two Masons hold up rods - one at either side of the road - as the group processes round a corner. The Walk has been running continuously since the eighteenth century and is central to life in the village, with the second day of January taking on more importance in terms of the calendar 
than New Year's Day and acting as a time in which village "ex-pats" typically return to be with family and friends.

We know that both traditional melodies of Scotland and ones with a Masonic connection were used in the nineteenth century to accompany the procession. George Riddell of Rosehearty noted the following down from Auld Jeck, otherwise known as John Ritchie, a fife player who led the procession: "Colonel Hay," "Duke Willie," "The Lass o Glenshee," "Supple Sandy," "Drumdelgie," and "I Kissed my Love wi' his Apron On" (Campbell 2008a), the last being the Masonic tune given above (see Fig. 8). As time has gone on, however, specific Masonic tunes have fallen out of the repertoire, and the single fife player has been replaced by a pipe band. The tunes played nowadays by the band are classics within the repertoire of Scottish traditional music and readily recognizable to many, and a good number are also songs, for instance, "Rowan Tree" and "Bonnie Gallowa." If we think of the procession as having an aural dimension in addition to a visual one, we get the idea not only of significant sights but also of significant sounds within the procession, of which these tunes are clearly a part. Such tunes give the onlookers (and Masons, for that matter) an opportunity to participate in the songs, even if the words are simply going on in their minds as they hear the tunes. Inherent in the procession is the idea of a "soundscape" (Shelemay 2006) in addition to a landscape. The community and the Masons expect to hear significant sounds within the ritual. This point has been highlighted by Russell (2002-03) in his work on the processions of neighboring fishing villages in the Northeast of Scotland, which have their roots in the Temperance movement rather than in Freemasonry. Here a mixture of sacred and secular material is played by the community, and a particularly significant aural (and visual) aspect is when one of the community members "taks a stannin beat" on the big bass drum outside the home of someone who is housebound or elderly. This is a way of paying tribute aurally to a member of the community.

Nowadays, one of the tunes played by the pipe band to finish off proceedings is "Highland Cathedral." This is a popular slow air that, although modern, encapsulates for many a national sentiment, as does "Scots Wha Hae." The idea of an anthem as something that can unify is discussed by McLucas (2010:129), and here we see it as something that brings the Masons and the whole community together. The tune formerly used for this part of the ceremony was "Ho Ro The Merry Masons." In 2007, I collected this tune (see Fig. 11) from Mr. Crawford, a senior member of the Lodge. He told me that the tune used to be played by the pipe band, but that with the passage of time and generational shift, it was not known to people in the group and consequently dropped out of the repertory. This change is in contrast to the practice at Melrose, where it is very much still part of the ceremony.

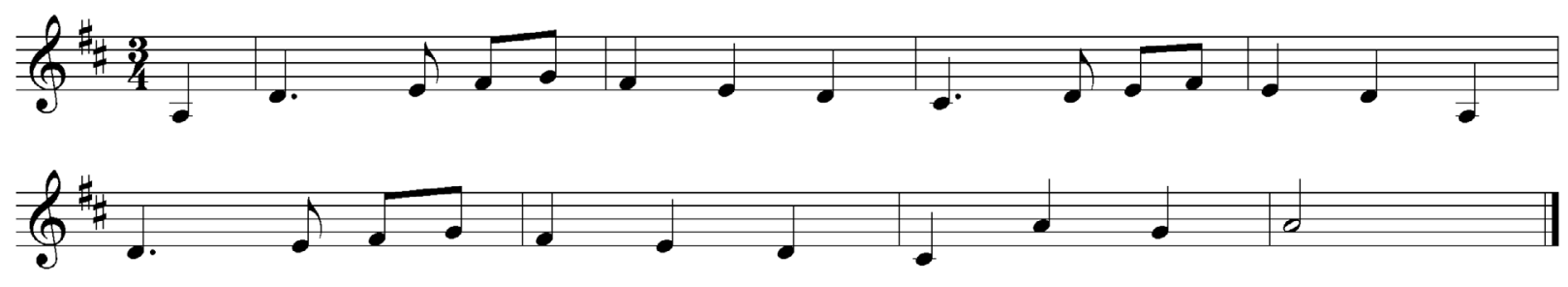

Fig. 11: "Ho Ro The Merry Masons." 
James C. Dick tells us that this tune was known to have been sung by children in the streets in the West of Scotland in the nineteenth century to the following words (Dick 1903:441):

Hey the merry Masons, and ho the merry Masons

Hey the merry Masons goes marching along.

It will be of no surprise to scholars of oral tradition to find that the Rosehearty tune is a variant of the tune we first hear about in the Masonic context in 1723, namely "The Enter'd Prentice's Song." Although the connections between the two tunes may not be immediately apparent, particularly as far as the rhythm is concerned, when one looks at the overall contour ${ }^{11}$ of the two melodies, one sees that the opening two bars are almost identical, with the bold "sohdoh" leap at the beginning being prominent.

The Masonic song tradition can be seen as one where gender division eventually dissipated in the case of some of the material to incorporate a broader, mixed community, and where some of the songs of the Masons made it out of their specific repertory and into the community at large, serving to bind the community together on particular occasions. The specific catalyst for this shift was the oral/aural tradition that allowed others to hear and experience the songs outside of the Lodges. The tunes that have survived in this context are particularly those folk tunes that are easily remembered, assimilated, and sung.

University of Edinburgh

\section{References}

Anderson 1723

Anderson 1738

Andrews 2004

Bohlman 1988
James Anderson. The Constitutions of the Free-Masons. Containing the History, Charges, Regulations, \&c. of that Most Ancient and Right Worshipful Fraternity. For the Use of the Lodges. London: William Hunter for John Senex and John Hooke.

The New Book of Constitutions of the Antient and Honourable Fraternity of Free and Accepted Masons. London: Caesar Ward and Richard Chandler.

Corey Andrews. Literary Nationalism in Eighteenth-Century Scottish Club Poetry. Lewiston, NY: Edwin Mellen Press.

Philip V. Bohlman. The Study of Folk Music in the Modern World. Bloomington: Indiana University Press.

\footnotetext{
${ }^{11}$ Contour analysis is a technique used and discussed by Shapiro (1985:404-17).
} 
Callendar 1758

Campbell 2008a

Campbell 2008b

Chappell 1855-59

Christie 1876-81

Clark 2000

Denslow and Truman 1957

Dick 1903

Falck and Picker 2012

Finnegan 1992

Gelbart 2007

Greig 1963

Johnson and Burns 1787-1803

Jones 1956
James Callendar. A Collection of Free Masons Songs. Edinburgh: Br. A. Donaldson.

. "George Riddell of Rosehearty: Fiddler and Collector." In Driving the Bow: Fiddle and Dance Studies from Around the North Atlantic 2. Ed. by Ian Russell and Mary Anne Alburger. Aberdeen: The Elphinstone Institute, University of Aberdeen. pp. 35-56.

Katherine Campbell. "The Masons' Walk at Rosehearty." Review of Scottish Culture, 20:127-32.

William Chappell. Popular Music of the Olden Time. 2 vols. London: Cramer, Beale, and Chappell.

William Christie. Traditional Ballad Airs. 2 vols. Edinburgh: Edmonston and Douglas; David Douglas.

Peter Clark. British Clubs and Societies 1580-1800. Oxford: Clarendon Press.

William R. Denslow and Harry S. Truman. 10,000 Famous Freemasons. 2 vols. Richmond, VA: Macoy. Rpt. 2004. Whitefish, MT: Kessinger.

James C. Dick, ed. The Songs of Robert Burns. London: Henry Frowde.

Robert Falck and Martin Picker. "Contrafactum" in Grove Music Online. Oxford Music Online. Available via subscription at http://www.oxfordmusiconline.com/ subscriber/article/grove/music/06361.

Ruth H. Finnegan. Oral Traditions and the Verbal Arts: A Guide to Research Practices. London: Routledge.

Matthew Gelbart. The Invention of "Folk Music" and "Art Music": Emerging Categories from Ossian to Wagner. Cambridge: Cambridge University Press.

Gavin Greig. Folk-Song in Buchan and Folk-Song of the North-East. Foreword by Kenneth S. Goldstein and Arthur Argo. Hatboro, PA: Folklore Associates.

James Johnson and Robert Burns. The Scots Musical Museum, 1787-1803. 2 vols. Ed. and intro. by Donald A. Low. Aldershot: Scolar Press. Facsimile reprint ed. 1991.

Bernard E. Jones. Freemasons' Guide and Compendium. New and rev. ed. London: Harrap. 
Karpeles 1974

Kinsley 1968

Low 1993

Mackey 1929

McLucas 2010

McNaughtan 1990

MacNulty 1991

Moffat 2008

The Musical Mason c.1764-78

Nettl 1982

Porter 2009

Riddell 1906-11

Roeck 1995
Maud Karpeles, ed. Cecil Sharp's Collection of English Folk Songs. 2 vols. London: Oxford University Press.

James Kinsley, ed. The Poems and Songs of Robert Burns. 3 vols. Oxford: Oxford University Press.

Donald A. Low, ed. The Songs of Robert Burns. London: Routledge.

Albert G. Mackey. Encyclopedia of Freemasonry and Kindred Sciences. New ed. London: The Masonic History Company.

Anne Dhu McLucas. The Musical Ear: Oral Tradition in the USA. Farnham, Surrey: Ashgate.

Adam McNaughtan. “A Century of Saltmarket Literature, 1790-1890.” In Six Centuries of the Provincial Book Trade in Britain. Ed. by Peter C. G. Isaac. Winchester: St. Paul's Bibliographies. pp. 165-80.

W. Kirk MacNulty. Freemasonry: A Journey Through Ritual and Symbol. London: Thames and Hudson.

Kenneth Erik Moffat. In Search of Ancient Britain. DVD. Not Even a Shoestring Productions: Hawick.

The Musical Mason or Free Mason's Pocket Companion being a Collection of Songs used in all Lodges to which are added the Free Mason's Mark and Ode. London: C \& S Thompson.

Bruno Nettl. "Types of Tradition and Transmission." In Cross-Cultural Perspectives on Music. Ed. by Robert A. Falck and Timothy Rice. Toronto: University of Toronto Press. pp. 3-19.

James Porter. Genre, Conflict, Presence: Traditional Ballads in a Modernizing World. Trier: Wissenschaflicher Verlag Trier.

George Riddell. "A Set of Six Old Airs, with Notes." Miscellanea of the Rymour Club, 1:116-21.

Alfons Roeck. "Freemasonry in Modern Folk Stories in Belgium (Flanders) and the Netherlands." In Folk Narrative and Cultural Identity: 9th Congress of the International Society for Folk-Narrative Research. Ed. by Vilmos Voigt. Budapest: Department of Folklore, Eötvös Loránd University. pp. 674-84. 
Russell 1986

Russell 2002-03

Seeger 1987

Shapiro 1985

Shelemay 2006

Shuldham-Shaw et al. 1981-2002

Stell 2008-

Stevenson 1987

Stevenson 1988

St Cecelia 1782

Wade 1861

Wilson and Chambers 1840
Ian Russell. "Context and Content: A Study of the Repertoires of Arthur Howard." In Singer, Song and Scholar. Ed. by Ian Russell. Sheffield: Sheffield Academic Press. pp. 31-54. "Flute Bands and their Annual Walks in North-East Scotland: Music, Tradition, and Community." Review of Scottish Culture, 15:99-111.

Anthony Seeger. Why Suyá Sing: A Musical Anthropology of an Amazonian People. Cambridge: Cambridge University Press.

Anne Dhu Shapiro, ed. Music and Context: Essays for John M. Ward. Cambridge, MA: Department of Music, Harvard University.

Kay Kaufman Shelemay. Soundscapes: Exploring Music in a Changing World. London: Norton.

Patrick Shuldham-Shaw, Emily B. Lyle, et al., eds. The Greig-Duncan Folk Song Collection. 8 vols. Aberdeen and Edinburgh: Mercat Press for the University of Aberdeen in association with the School of Scottish Studies, University of Edinburgh.

Evelyn Stell. "Early Scottish Melodies Online." http://www.melody. celtscot.ed.ac.uk

David Stevenson. "The Scottish Origins of Freemasonry." In Aberdeen and the Enlightenment. Ed. by Jennifer J. Carter and Joan H. Pittock. Aberdeen: Aberdeen University Press. pp. 36-39.

The Origins of Freemasonry: Scotland's Century, 1590-1710. Cambridge: Cambridge University Press.

St Cecilia; or, The British Songster: A New and Select Collection of the Best Scotch and English Songs. Edinburgh: Campbell Denovan.

James A. Wade. History of St. Mary's Abbey, Melrose, the Monastery of Old Melrose, and the Town and Parish of Melrose. Edinburgh: Thomas C. Jack.

John Wilson and Robert Chambers. The Land of Burns. Glasgow: Blackie and Son. 
This page is intentionally left blank. 
Oral Tradition, 27/1 (2012): 109-160

\title{
The Storyteller, the Scribe, and a Missing Man: Hidden Influences from Printed Sources in the Gaelic Tales of Duncan and Neil MacDonald
}

\author{
William Lamb
}

\section{Introduction}

The Scottish Gaelic tradition bearer Duncan MacDonald ${ }^{1}$ (1883-1954) was one of the most remarkable storytellers of twentieth-century Europe. ${ }^{2}$ He piqued the interest of a host of ethnologists in the later years of his life because of his considerable repertoire of traditional knowledge. They were especially interested in his ability to tell certain tales of his-particularly those with ties to older literary versions in manuscripts ${ }^{3}$ - in a virtually identical fashion from recitation to recitation. During a period when scholars were admitting that the conservatism of Gaelic oral tradition had been perhaps exaggerated at times (see Ó Duilearga 1945), Duncan MacDonald's abilities were seen as an acquittal of the seanchaidh. ${ }^{4}$ It became clear that it was possible in certain cases for the surface forms of language, not just plot, to survive down through the ages in an almost unaltered form. MacDonald's genealogy (see Matheson 1977), with its ties to the hereditary poets and historians of Clann Dòmhnaill of Sleat, suggested that he was an approximation of the kind of professional Gaelic storyteller that would have been an institution in earlier times.

1 Originally from Snishaval (Snaoiseabhal), South Uist. He was better known as Dunnchadh Clachair _ “Duncan the Stone-mason”_or by his patronymic Dunnchadh 'ac Dhòmhnaill 'ac Dhunnchaidh.

${ }^{2}$ For biographies, see MacGillEathain 1954 and Matheson 1977.

3 The classic study of this genre of formal storytelling is Bruford 1966. The Gaelic romances were hero tales that were composed in medieval and early modern times evidently to entertain the nobility of the day. They circulated in manuscript form, on both sides of the Sea of Moyle, and were written in a largely grapholectic, formal form of the language known as Classical Gaelic. Although Classical Gaelic would have seemed rather antiquated to many of the Scottish - and Irish-Gaels who listened to the stories and songs composed in it, it is clear that they comprehended much and that some Scottish bards and storytellers were fluent in it (see J. L. Campbell and Thomson 1963).

4 Seanchaidh is generally translated as "storyteller" or "tradition bearer," but it has a wider semantic range than that; seanchaidhean would normally be expert genealogists and local historians as well. They were the professors of oral tradition, as it were, for each area. 
Maartje Draak (1957) was the first scholar to comment upon the verbal consistency of Duncan's narratives. She compared two versions of a story well known as Fear na h-Eabaid ${ }^{5}$ ("The Man of the Habit"). The first was taken down by K. C. Craig in 1944 and published in Sgialachdan Dhunnchaidh (MacDhòmhnaill and Craig 1950), and the second was recorded on wire in 1950 by John Lorne Campbell. ${ }^{6}$ Campbell's recording was transcribed for a folklore conference that Draak attended (Du. MacDonald 1953). ${ }^{7}$ Draak says that his narration at the conference-where he had been invited to give a demonstration-was "nearly word perfect" (1957:47) when compared to the transcription of Campbell's 1950 recording; however, when compared to Craig's 1944 transcription, there were instances of imperfections and "story decay" (ibid.:53). Most of these changes seem negligible ${ }^{8}$ when considering the length and complexity of the story as well as the crucial fact that Craig's version was more temporally removed than Campbell's. ${ }^{9}$ Additionally, Draak's equating him to a literatus at one point (1957:54) is an indication of the standard that was being employed.

Bruford $^{10}$ (1979) extended Draak's analysis

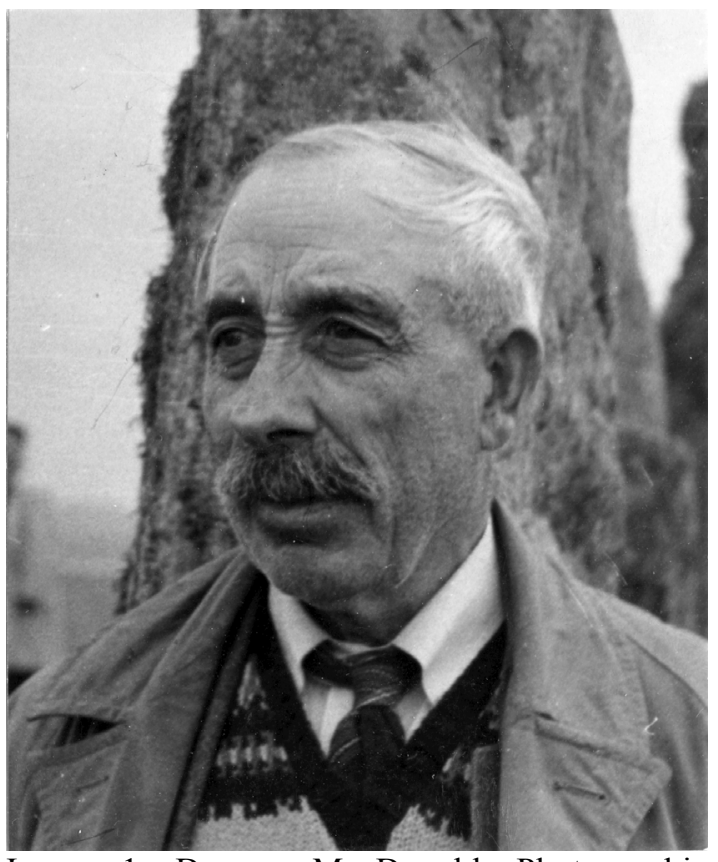

Image 1: Duncan MacDonald. Photographic archive of the School of Scottish Studies.

with the inclusion of another four versions, totaling six altogether. Importantly, Bruford included a text from Duncan's brother Neil, also a storyteller of note. This text was taken from the manuscript collection of Donald John MacDonald (1919-1986), Duncan's son (see §3.1.2 below). The various versions of Fear na h-Eabaid are listed below for ease of reference and are in diachronic order. The abbreviations are as per the original, and the word counts are from the present study:

${ }^{5}$ For a history of this tale, originally a medieval literary romance, see Bruford 1968.

${ }^{6}$ See http://www.tobarandualchais.co.uk/fullrecord/24358/1 for this recording.

7 The "International Conference on Celtic Folklore," held in Stornoway and Oban in 1953.

${ }^{8}$ Such as substituting the word subhachas ("gladness") for the word dubhachas ("sadness"), and occasional character conflations.

9 This is a key point: two narratives that were collected from an individual around the same time period are likely to share more in common with one another than are two that are relatively more temporally removed from each other.

${ }^{10}$ Dr. Allan Bruford (1937-1995) was a Senior Lecturer and Archivist at the School of Scottish Studies. 
D1 (1936): Peggy McClements, ${ }^{11}$ from dictation, 5171 words.

D2 (1944): K. C. Craig, from dictation, and published in MacDhòmhnaill and Craig 1950, ${ }^{12} 6571$ words.

D3 (1947): Calum Maclean, transcribed from an Ediphone recording made for the Irish Folklore Commission (IFC MS 1031:152-85), 6771 words.

D4 (1950): John Lorne Campbell, recorded on wire and transcribed by Matheson and Thomson (Du. MacDonald 1953), 7492 words.

D5 (1953): Calum Maclean, recorded on tape for the School of Scottish Studies and transcribed by Donald Archie MacDonald (SA 1953/34 A4-35 A1), 7381 words.

N (1955): Donald John MacDonald, from the dictation of Neil MacDonald, for the School of Scottish Studies (DJM MS 3524-83), 6109 words. ${ }^{13}$

Bruford's paper bolsters Draak's findings and conclusions for the most part, providing a running account of the different types of variation found among the texts. Unlike Draak, however, he does not cast discrepancies in negative terms, and he highlights the impressive similarity between the renditions (Bruford 1979:33-34):

I have not produced examples of the most remarkable feature, that for the most part all six texts are almost identical in wording - it is easier to study the differences because they are only a small part of the whole. ... Brief comparisons of the different versions of other tales of this type which Duncan told - the other four printed by Craig (1944) in fact ${ }^{14}$ - suggest equal if not greater consistency in wording. [emphasis added]

Bruford thought that this level of consistency was unusual in his experience of contemporary Gaelic storytelling, in Uist and elsewhere. He offered two possible explanations for it. One was that Duncan had remembered the stories verbatim as told by his father, from whom the vast majority of them had come. The other was that he had stabilized his versions as an adult by way of repetition, preserving the plot and some of the formal language that he had heard from his

11 Peggy McClements (née Lowe) collected the tale while she was an undergraduate in Celtic at the University of Edinburgh. She worked at the School of Scottish Studies for many years and produced a wealth of transcriptions of Gaelic traditional narrative.

12 All of the bibliographic databases that I have encountered have Sgialachdan Dhunnchaidh as being published in 1944, but Calum Maclean (MacGillEathain 1954) indicates that it was published in the Autumn of 1950. The confusion may relate to the fact that the only date listed in its front matter is the year in which the stories were collected (quote as in original): "Seann sgialachdan air an gabhail le Dunnchaidh [sic] mac Dhomhnaill ac Dhunnchaidh, Uibhist a Deas, mar a chual e aig athair fhein iad, 1944" ("Old stories told by Duncan MacDonald son of Duncan, South Uist, as he heard them from his own father, 1944"). Additionally, in the biography collected from Duncan in 1950 and published in Tocher (Matheson 1977:8), he mentions that the book had yet to be published, but that it was expected soon.

${ }^{13}$ Bruford notes that this version was taken down "probably on tape" (1996:190).

${ }^{14}$ See note 12 above. 
father. Bruford initially favored the latter explanation, but he revised his position when he discovered that Neil's versions of the hero tales were virtually the same, word for word (Bruford 1979: 34):

... it seems clearly disproved by the texts from Neil MacDonald, which are for the most part as close to his brother's texts as one of those is to another. . . . It seems clear that both brothers had learned some of the their father's tales virtually word for word. [emphasis added]

This remarkable observation, that two members of a storytelling family had stories learned from oral transmission that were almost identical — not simply in terms of motif structure, but in the actual language used as well—raised the bar considerably regarding the potential for linguistic conservatism in traditional Gaelic narrative. Subsequent publications have commented on the importance of this conservatism (Bruford 1981:103, 1996:177-78; Bruford and MacDonald 2003:453; Zall 1998:12-13, 2007-10:210), and perhaps Draak styling Duncan as a literatus was not actually very far from the mark; it was as if the two brothers had acted as faithful amanuenses for their father's recitations. Bruford's observation (1979:35-37) that Duncan's versions of less formal storytelling genres, such as Märchen and local legend, tended to show significantly more variation implied that the family had made a distinction in their repertoirealbeit a subconscious one-between tales with more formal, literary origins and those with a more purely oral, informal background. Accordingly, an almost literate aesthetic - the concept of an ideally immutable, lexically "correct" version - had perhaps become attached to certain of their tales. ${ }^{15}$

While I was writing a theoretical paper on the oralization and mnemonic retention of the literate Gaelic romances, I decided to investigate quantitatively the extent to which Neil and Duncan MacDonald's tales shared the same language. The data that Bruford provided, and a cursory examination of the raw evidence, seemed to fit well with the emerging hypotheses. However, as I discovered, all of the textual evidence that we have of Neil's storytelling comes from one source: the manuscript collection of Uist oral tradition made by Donald John MacDonald, Duncan's son (see $\$ 3.1 .1$ below for further information). In every case, the language of Neil's stories is almost identical to Duncan's when examining two sources: the tales published by K. C. Craig (1947; MacDhòmhnaill and Craig 1950) and those attributed to Duncan himself in Donald John's collection. However, their proximity diminishes when other sources are considered, such as the transcriptions and recordings made of Duncan by Peggy McClements (1936), John Lorne Campbell (early 1950s), and Calum Iain Maclean (1947-53). In other words, the stories contributed by Donald John from Duncan and Neil are more similar to those of Craig - and to each other - than to versions taken down by other collectors.

15 During the preparation of this essay, I believed that neither brother could apparently read Gaelic (Innes 2011); however, it has since come to light that both Duncan and Neil were indeed probably literate. According to Donald John's stepson, Donald MacNeil — who had worked closely with Neil as an apprentice-the brothers could read and write in Gaelic and English (MacNeil 2011). Dr. Andrew Wiseman, a colleague who worked on the Calum Maclean Project (available with registration at http://www.calum-maclean.celtscot.ed.ac.uk/calmac), points out to me that in Duncan's autobiography, which was collected by MacLean, he states that he is literate. 
This finding is anomalous since Donald John's texts are the most temporally distant from Craig's transcriptions of any of the extant versions. One would expect the language of storytellers to evolve over time. For a person to revert back suddenly to how he or she told a tale ten years previously would be highly unusual. Furthermore, it is understood that Neil is a separate individual from Duncan. These two variables - temporal distance and the involvement of a separate narrator-would be expected to be associated with more, rather than less, variation. A close textual examination of the texts, such as the ones Bruford himself conducted, provides hints of the underlying relationship between Donald John's texts and those of Craig. However, once a quantitative analysis is carried out, the level of intersection between them is so extensive, and their divergence from the texts of other collectors so marked, as to suggest only one conclusion: Donald John's texts of Neil and Duncan are not independent from Craig's published texts of Duncan. In fact, there is strong evidence (see $\$ 3.1 .3$ below) to suggest that Donald John visually copied Craig's work into his manuscripts, word for word in some places, and slightly altered in others. This is a surprising finding, and it raises a number of interesting questions and implications that will be explored in the current paper.

In the analyses that follow, I employ the following abbreviations:

$\begin{array}{ll}\text { Cat } & \text { Am Fear a Thug Cait dhan Tuirc } \\ \text { CG } & \text { Conall Gulban } \\ \text { CIM } & \text { Calum Iain Maclean } \\ \text { DJM } & \text { Donald John MacDonald } \\ \text { DJM-D } & \begin{array}{l}\text { Duncan MacDonald's texts in the Donald John MacDonald manuscript } \\ \text { collection }\end{array} \\ \text { DJM-N } & \text { Neil MacDonald's texts in the Donald John MacDonald manuscript } \\ & \text { collection } \\ \text { EM } & \text { Eachdraidh Mhànuis } \\ \text { GS } & \text { Gruagach nan Sealg } \\ \text { IFC } & \text { Irish Folklore Commission } \\ \text { IO } & \text { Iain Òg Mac Righ na Frainge } \\ \text { JLC } & \text { John Lorne Campbell } \\ \text { MWHT } & \text { More West Highland Tales } \\ \text { NP } & \text { Noun phrase } \\ \text { Old MS } & \text { "Old manuscript" } \\ \text { REFL } & \text { Reflexive } \\ \text { TM } & \text { Sgeulachd an Tuairisgeil Mhoir }\end{array}$

\section{Methodology}

\subsection{Data}

All of the tales that Duncan and Neil MacDonald had in common were collated using the database in the Tale Archive of the School of Scottish Studies. Those tales that were also in a 
publication of Craig's were prioritized and considered for analysis. A further two sets of texts were included in the dataset to investigate potential relationships with tales in More West Highland Tales (J. F. Campbell 1940). Table 1 below summarizes the data:

Table 1: A selection of Duncan and Neil's tales in the D. J. MacDonald manuscripts ${ }^{16}$

\begin{tabular}{|c|c|c|c|c|c|}
\hline \multirow[b]{2}{*}{ Tale name } & \multicolumn{2}{|c|}{ DJM manuscripts } & \multirow[b]{2}{*}{ Printed source } & \multicolumn{2}{|c|}{$\begin{array}{c}\text { Alternative versions (mostly from } \\
\text { Duncan MacDonald) }\end{array}$} \\
\hline & $\begin{array}{l}\text { Duncan } \\
\text { (DJM-D) }\end{array}$ & $\begin{array}{c}\text { Neil } \\
\text { (DJM-N) }\end{array}$ & & $\mathbf{A}$ & B \\
\hline $\begin{array}{l}\text { Am Fear a Thug am } \\
\text { Boireannach às an } \\
\text { Tuirc (ATU 506) }\end{array}$ & $\begin{array}{l}9 / 9 / 53 \\
390-438\end{array}$ & -- & Craig 1949:134-44 & $\begin{array}{l}\text { CIM: } 31 / 01 / 49 \\
\text { IFC MS 1156: } \\
\text { 202-37 (as Eilean } \\
\text { an Òir) }\end{array}$ & $\begin{array}{l}\text { JLC: } 07 / 12 / 50 \\
\text { Tape ID: } \\
\text { CW0083 }\end{array}$ \\
\hline $\begin{array}{l}\text { *Am Fear a Thug } \\
\text { Cait dhan Tuirc/An } \\
\text { Dà Sgiobair (ATU } \\
\text { 1651/506) }\end{array}$ & -- & $\begin{array}{l}22 / 11 / 54 \\
2634-60\end{array}$ & $\begin{array}{l}\text { J. F. Campbell } \\
\text { 1940:372-92 }\end{array}$ & $\begin{array}{l}\text { DJM MSS: Mary } \\
\text { Ann MacInnes } \\
\text { 20/05/57 } \\
6248-75\end{array}$ & \\
\hline $\begin{array}{l}\text { An Ceatharnach } \\
\text { Caol Riabhach }\end{array}$ & -- & $\begin{array}{l}6 / 11 / 53 \\
596-605\end{array}$ & unknown & $\begin{array}{l}\text { CIM: } 7 / 1 / 49 \\
\text { IFC MS 1180: } \\
105-07\end{array}$ & -- \\
\hline *An Tuairisgeul Mòr & $\begin{array}{l}8 / 2 / 54 \\
948-1002\end{array}$ & $\begin{array}{l}12 / 2 / 55 \\
3079-148\end{array}$ & $\begin{array}{l}\text { MacDhòmhnaill and Craig } \\
\text { 1950:59-72 }\end{array}$ & $\begin{array}{l}\text { CIM: 12/01/47 } \\
\text { IFC MS 1031: } \\
\text { 103-51 }\end{array}$ & $\begin{array}{l}\text { JLC: } 14 / 02 / 50 \\
\text { Tape ID: } \\
\text { CW0056 }\end{array}$ \\
\hline *Conall Gulban & $\begin{array}{l}2 / 2 / 54 \\
881-932\end{array}$ & $\begin{array}{l}22 / 12 / 54 \\
2847-910\end{array}$ & $\begin{array}{l}\text { MacDhòmhnaill and Craig } \\
\text { 1950:45-58 }\end{array}$ & $\begin{array}{l}\text { CIM: } 26 / 1 / 48 \\
\text { IFC MS } 1054 \\
1-57\end{array}$ & $\begin{array}{l}\text { JLC: } 17 / 02 / 50 \\
\text { Tape ID: } \\
\text { CW0066 }\end{array}$ \\
\hline $\begin{array}{l}\text { *Eachdraidh } \\
\text { Mhànuis }\end{array}$ & $\begin{array}{l}5 / 1 / 53 \\
779-825\end{array}$ & -- & $\begin{array}{l}\text { MacDhòmhnaill and Craig } \\
\text { 1950:1-16 }\end{array}$ & $\begin{array}{l}\text { CIM: 08/01/49 } \\
\text { IFC MS 1179: } \\
207-66\end{array}$ & $\begin{array}{l}\text { JLC: } 16 / 02 / 50 \\
\text { Tape ID: } \\
\text { CW0063 } \\
\end{array}$ \\
\hline *Fear na h-Eabaid & -- & $\begin{array}{l}14 / 5 / 55 \\
3524-83\end{array}$ & $\begin{array}{l}\text { MacDhòmhnaill and Craig } \\
\text { 1950:17-29 }\end{array}$ & \multicolumn{2}{|c|}{$\begin{array}{l}\text { See above for a list of alternate } \\
\text { versions. }\end{array}$} \\
\hline $\begin{array}{l}\text { *Gruagach nan } \\
\text { Sealg/Mar a } \\
\text { Cheileadh an } t \text {-Sealg } \\
\text { air an Fhinn }\end{array}$ & $\begin{array}{l}1 / 10 / 53 \\
481-96\end{array}$ & $\begin{array}{l}22 / 12 / 54 \\
2774-92\end{array}$ & Craig 1947:245-50 & $\begin{array}{l}\text { CIM: 11/01/49 } \\
\text { IFC MS 1171: } \\
\text { 393-406 }\end{array}$ & -- \\
\hline $\begin{array}{l}\text { *Iain Òg Mac Righ } \\
\text { na Frainge }\end{array}$ & $\begin{array}{l}5 / 4 / 54 \\
1250-300\end{array}$ & $\begin{array}{l}12 / 11 / 54 \\
2493-553\end{array}$ & $\begin{array}{l}\text { J. F. Campbell 1940:Chapt. } \\
17\end{array}$ & $\begin{array}{l}\text { DJM MSS: from } \\
\text { "an old } \\
\text { manuscript": } \\
6278-322\end{array}$ & -- \\
\hline
\end{tabular}

16 The information supplied for the Donald John MacDonald collection is the date that each tale was collected (as noted on the accession sheet) and its page numbers. Items marked with an asterisk (*) are analyzed within the current essay. Within this chart and the following discussion "ATU" is an abbreviation for "AarneThompson-Uther" and refers to a tale-type number, as represented in The Types of International Folktales (Uther 2011). Similarly, "CW" is an abbreviation for "Canna Wire," referring to the older material collected by John Lorne Campbell; the associated links are to the Tobar an Dualchais/"Kist o Riches" website, a portal that allows access to ethnographic audio recordings from the School of Scottish Studies, the BBC, and the Canna archive. 


\begin{tabular}{|l|l|l|l|l|l|}
\hline $\begin{array}{l}\text { Mac an Ridire } \\
\text { Albannaich (ATU } \\
\text { 517) }\end{array}$ & $\begin{array}{l}6 / 8 / 53 \\
289-328\end{array}$ & $\begin{array}{l}8 / 12 / 54 \\
2680-734\end{array}$ & Craig 1947:231-45 & $\begin{array}{l}\text { CIM: 11/01/49 } \\
\text { IFC MS 1171: } \\
\text { 472-526 (as } \\
\text { Alasdair Mór mac } \\
\text { Righ na h-Eiphit) }\end{array}$ & -- \\
\hline $\begin{array}{l}\text { Na Trì } \\
\text { Comhairlichean } \\
\text { (ATU 910B) }\end{array}$ & $\begin{array}{l}19 / 5 / 54 \\
1544-57\end{array}$ & -- & $\begin{array}{l}\text { J. F. Campbell 1940: } \\
\text { Chapt. 6 }\end{array}$ & -- & - \\
\hline $\begin{array}{l}\text { Sgeulachd Mhic Righ } \\
\text { Lochlainn }\end{array}$ & $\begin{array}{l}14 / 1 / 54 \\
830-80\end{array}$ & $\begin{array}{l}15 / 1 / 55 \\
2952-3016\end{array}$ & $\begin{array}{l}\text { MacDhòmhnaill and Craig } \\
1950: 30-44\end{array}$ & $\begin{array}{l}\text { CIM: 10/01/48 } \\
\text { IFC MS 1053: } \\
\text { 408-60 }\end{array}$ & $\begin{array}{l}\text { JLC: } 15 / 02 / 50 \\
\text { Tape ID: } \\
\text { CW0056 }\end{array}$ \\
\hline
\end{tabular}

To ensure that the texts utilized the same orthographical system-crucial when conducting this type of analysis - they were laid out in columns to facilitate visual comparison (see examples in \$3.3) and standardized. This standardization was done roughly in concordance with the Gaelic Orthographic Conventions (SQA 2009). Where words could not be found in the dictionary, the spelling in Sgialachdan Dhunnchaidh (MacDhòmhnaill and Craig 1950) or J. F. Campbell 1994 was employed. Incidents of ellipsis were expanded to minimize false negativesfor example, $a$ th' ann > a tha ann-acute accents were made grave, and punctuation was excluded during the analysis.

The data for each tale included all available sources. Where sound recordings existed but no transcriptions were available, the transcribing was undertaken by the current author. The Fear na $h$-Eabaid texts were utilized in full, but for the other analyses samples of approximately 250-350 words were used. This methodology was found to be sufficient for detecting differences across the texts. The word counts for each sample varied (see Table 2 and Table 3), as they were defined on the basis of parallel motif structure and language, and were arranged so that each sample of a text was as semantically equivalent as possible. Unless otherwise stated, each sample was taken from the beginning of the text. Where taken from the end of a text, the sample ran back from the last word for as many words as are reported below. In three cases, samples were taken from the middle of a tale. The page numbers for these tales will be detailed in the relevant sections below.

Table 2: Word counts for Fear na h-Eabaid texts

\begin{tabular}{|cccccccc|}
\hline Craig & DJM-N & McClements & CIM53 & CIM47 & JLC & Mean & Total \\
\hline 6571 & 6109 & 5171 & 7381 & 6771 & 7492 & 6583 & 39495 \\
\hline
\end{tabular}


Table 3: Word counts for all sampled texts

\begin{tabular}{|ccccccccc|}
\hline Sample & $\begin{array}{c}\text { Published } \\
\text { text }\end{array}$ & DJM-N & DJM-D & CIM & JLC & Old MS & Mean & Totals \\
\hline TM beg & 258 & 277 & 256 & 258 & 318 & & 273 & 1367 \\
TM end & 323 & 334 & 357 & 347 & 391 & & 350 & 1752 \\
CG & 246 & 257 & 253 & 290 & 271 & & 263 & 1317 \\
EM & 244 & & 262 & 420 & 436 & & 341 & 1362 \\
GS & 447 & 462 & 455 & 517 & & & 470 & 1881 \\
Cat beg & 353 & 537 & & & & & 445 & 890 \\
Cat mid & 410 & 483 & & & & & 447 & 893 \\
Cat end & 269 & 282 & & & & & 276 & 551 \\
IO beg & 325 & 425 & 366 & & & 389 & 376 & 1505 \\
IO mid & 237 & 238 & 265 & & & 215 & 239 & 955 \\
IO end & 217 & 241 & 237 & & & 446 & 285 & 1141 \\
Mean & 303 & 354 & 306 & 366 & 354 & 350 & & \\
Totals & 3329 & 3536 & 2451 & 1832 & 1416 & 1050 & & 13614 \\
\hline
\end{tabular}

\subsection{Statistical and computational techniques}

To gauge the intersection between the different versions of the texts, a calculation that is commonly employed in plagiarism detection was used, the Dice similarity coefficient (Alzahrani et al. 2012); it was implemented with WordSmith Tools (Scott 2011), a widely available software package. The measure describes the overlap between two texts on the basis of shared tokens (words, in this case), using the following formula:

$$
D(x, y)=\frac{2|x \cap y|}{|x|+|y|}
$$

In essence, the coefficient is twice the total number of shared words in documents $x$ and $y$, divided by the total number of words found in document $x$ along with the total number of words in document $y$. The results range from 0 to 1 , much like a typical correlation. A return of null would indicate that the texts are completely unrelated to one another ${ }^{17}$ and a return of 1 that they are exactly the same. Although the measure is unable to detect syntactic relationships, ${ }^{18}$ it is a good indication of lexical similarity. The next section will describe the results from the analyses.

17 This result would be highly unlikely due to the effect of common, co-occurring lexemes.

18 It is currently not possible to automate syntactical analysis in Gaelic, but there are initiatives afoot that would hopefully make such analysis a reality at some point in the future (Bauer et al. 2009). 


\section{Results}

The first part of this section will focus on the Fear na h-Eabaid texts, which have received the most attention in the literature. The quantitative results will be presented and discussed (\$3.1.1), followed by background information on Donald John MacDonald and his collection (\$3.1.2). Then, the evidence suggesting that Donald John was engaged in visual copying will be provided (\$3.1.3), followed by an examination of the linguistic differences in evidence between the texts of K. C. Craig and Donald John (\$3.1.4). This methodology will thus lay the groundwork for a series of subsequent analyses (\$3.2-3.3) with the aim of extending the scope of the investigation and answering the following questions:

1. To what extent were Donald John's submissions dependent upon Craig's publications?

2. Can we detect a distinction between the texts attributed to Duncan and Neil?

3. Is there evidence that Donald John utilized published sources other than Craig's publications?

\subsection{The Fear na h-Eabaid Texts}

\subsubsection{Quantitative Results and Discussion}

As mentioned above, the six texts that are included in the present analysis of Fear $n a h$ Eabaid are the same ones that were investigated by Bruford (1979). To provide a control, an unrelated text from Sgialachdan Dhunnchaidh was included as well, a hero tale known as Sgeulachd an Tuairisgeil Mhoir ("The Story of the Big 'Made Up Tale'," 7675 words). This text was processed so that it was orthographically equivalent to the others (see $\$ 2.1$ above for details). Full texts were used throughout, with a total word count of 47,170. Table 4 presents the results: 
Table 4: Dice coefficient results for the Fear na h-Eabaid texts and Sgeulachd an Tuairisgeil Mhòr ${ }^{19}$

\begin{tabular}{|ccc|}
\hline Text 1 & Text 2 & Relation \\
\hline Craig & DJM-N & $\mathbf{0 . 8 7}$ \\
Craig & CIM53 & 0.82 \\
CIM53 & JLC & 0.82 \\
Craig & JLC & 0.81 \\
CIM47 & Craig & 0.81 \\
CIM47 & CIM53 & 0.80 \\
CIM47 & JLC & 0.79 \\
DJM-N & CIM53 & 0.78 \\
Craig & McClements & 0.77 \\
DJM-N & JLC & 0.77 \\
CIM47 & DJM-N & 0.77 \\
CIM47 & McClements & 0.76 \\
DJM-N & McClements & 0.76 \\
CIM53 & McClements & 0.75 \\
JLC & McClements & 0.75 \\
Craig & TM & 0.45 \\
JLC & TM & 0.44 \\
McClements & TM & 0.44 \\
CIM53 & TM & 0.43 \\
CIM47 & TM & 0.43 \\
DJM-N & TM & 0.42 \\
\hline
\end{tabular}

The data in Table 4 is ranked in accordance with the relation value in the third column. As can be seen by looking at the bottom of the table, all of the Fear na h-Eabaid texts correlated comparatively weakly with Sgeulachd an Tuairisgeil Mhoir: there was a difference of 0.30 between the most concordant instance in this case (Craig and Sg TM: 0.45) and the two least concordant Fear na h-Eabaid texts (JLC and McClements: 0.75). In fact, the Fear na h-Eabaid texts are remarkably similar to one another across the range, indicating the consistency with which Duncan MacDonald told some of his tales. However, the most striking result here is that the two most concordant Fear na h-Eabaid texts are Craig, collected from Duncan in 1944, and DJM-N, written down by Donald John MacDonald in 1955, ostensibly from Neil's recitation. This result seems illogical. Not only is DJM-N the most recent text by two years, and therefore the most diachronically distant from Craig (eleven years of difference versus eight years for Clement's text), but it was also taken down from a separate individual, thereby distinguishing it from all of the other texts. No two of Duncan's own texts are as close to one another as Neil's version is to the one of his in Sgialachdan Dhunnchaidh. This is the case despite the fact that Neil's version contains a lacuna of approximately 730 words, omitting two episodes common to

${ }^{19}$ Here and throughout $\$ 3.1 .1$, "Craig" is used to refer to the 1944 version of Fear na h-Eabaid published in MacDhòmhnaill and Craig 1950. 
all of the other versions (discussed further in §3.1.3). One can assume that, had these episodes not been omitted, the relation value might have been higher still.

In order to provide corroboration for this result, another test commonly employed to detect plagiarism was performed on the Fear na h-Eabaid data: the cosine coefficient (see Table 5). ${ }^{20}$ It is interpreted in the same way as the Dice coefficient. The preparation of the texts was as above, although a stop list was employed, removing the fifty most common words. ${ }^{21}$

Table 5: Cosine coefficient results for the Fear na h-Eabaid texts

\begin{tabular}{|l|llllll|}
\hline & Craig & McClements & DJM-N & CIM53 & CIM47 & JLC \\
\hline JLC & 0.891 & 0.847 & 0.873 & 0.896 & 0.872 & 1 \\
CIM47 & 0.855 & 0.861 & 0.846 & 0.867 & 1 & 0.872 \\
CIM53 & 0.875 & 0.844 & 0.865 & 1 & 0.867 & 0.896 \\
DJM-N & $\mathbf{0 . 9 1 2}$ & 0.866 & 1 & 0.865 & 0.846 & 0.873 \\
McClements & 0.863 & 1 & 0.866 & 0.844 & 0.861 & 0.847 \\
Craig & 1 & 0.863 & $\mathbf{0 . 9 2 1}$ & 0.875 & 0.855 & 0.891 \\
\hline
\end{tabular}

These results confirm the previous finding: the two texts most similar to one another are Donald John MacDonald's transcription of Neil (DJM-N) and Duncan's version in Sgialachdan Dhunnchaidh (Craig). Despite the temporal distance between the two versions, the aforementioned episodic gap, and the fact that they came from different individuals, their similarity to each other is greater than any two of Duncan's own renditions of this story. It is highly unlikely that Neil, a recognized storyteller in his own right, ${ }^{22}$ memorized his version more or less word for word from K. C. Craig's book. Rather, it appears that Donald John took Duncan's version of Fear na h-Eabaid almost directly from Sgialachdan Dhunnchaidh but changed words and phrases in places, and wrote it down in his own particular orthographical style (see §3.1.3-3.1.4 below). Figure 1 provides a scan of the label filled out by him for this particular tale.

${ }^{20}$ My thanks to Dr. Michael P. Oakes for his help and advice, and for running the texts through his cosine coefficient application. See Oakes 1998 and 2012 as well as Maurer et al. 2006 for more information on this analysis.

21 A stop list removes a pre-determined set of words from the analysis before it commences. In language studies, it is often used to filter out the most common words of a language in order to increase the likelihood that the analysis will be based upon lexemes with potentially more semantic interest.

22 Bill Innes, in his introduction to Chi Mi (MacDhòmhnaill and Innes 1998:viii) says "Neil's knowledge of Gaelic folklore may have been even richer than his brother's," although, as an introvert, he did not attract the same level of attention as the more extroverted Duncan. 
Figure 1: Accession sheet label submitted by Donald John MacDonald for Neil MacDonald's recitation of Fear na h-Eabaid

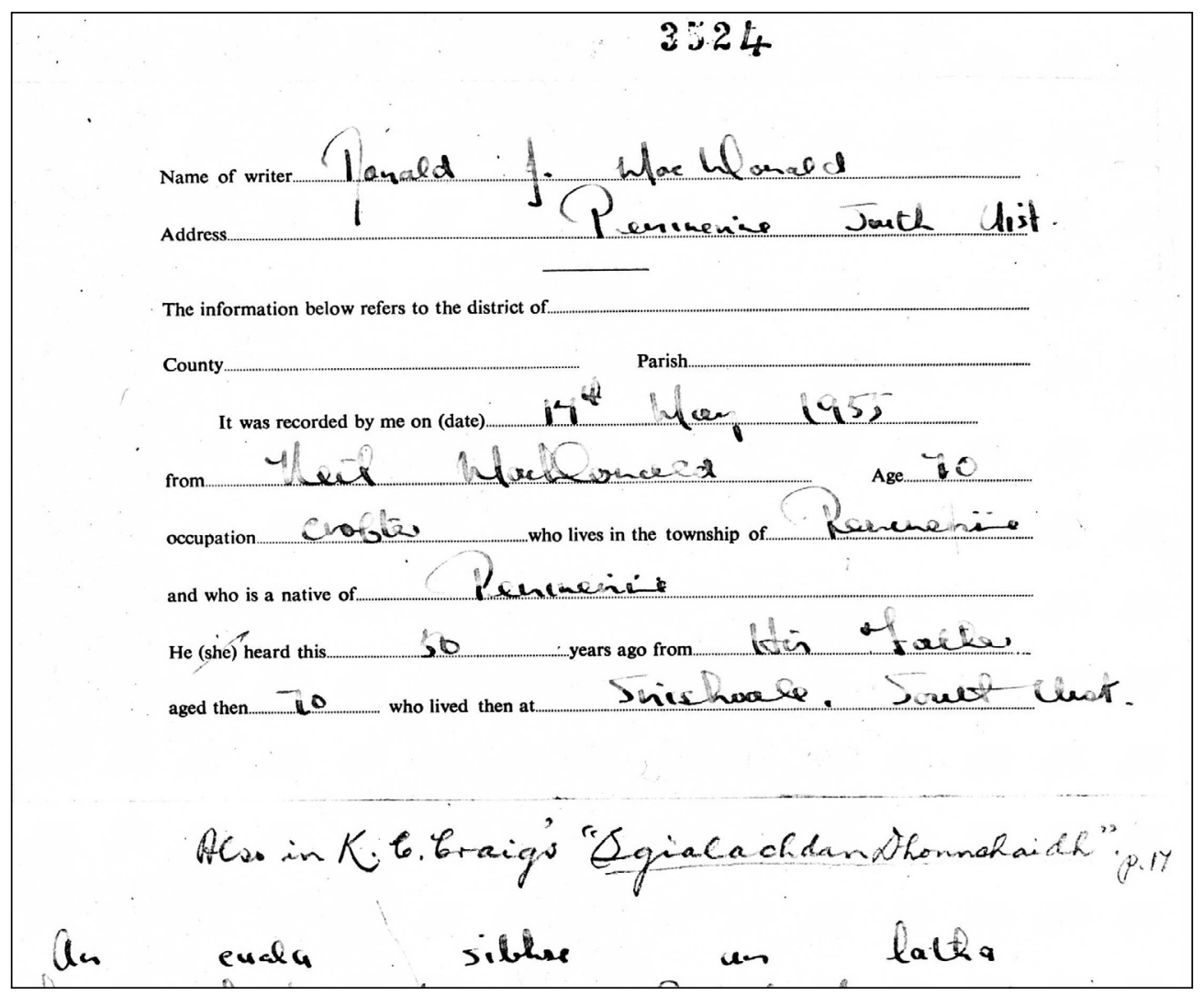

This accession sheet dates the recording session as 14 May 1955 and states that Neil had learned the tale from his father fifty years previously, thus clearly implying that the text has come from an oral source, recorded from a particular individual on a particular date.

Given that the relationship with Craig's book is so close, it is interesting to note that previous scholars-Bruford, in particular-did not detect this relationship. When one revisits Bruford's 1979 publication, it is notable that he often found the texts to be more in parallel than the other four versions. He even interprets the presence of the relationship between $\mathrm{N}$ (Neil) and D2 (Craig) in one case - the third quote below - as indicating that the brothers were likely to have heard the story from their father in a particular way:

$\mathrm{D} 2$ (and $\mathrm{N}$ ) ' . . duine ... a bhite fiachainn ri eallach a thogail dhà' (“. . . a person . . . for whom one was trying to lift something") (30).

$\mathrm{N}$ has much the same words as D2, though the order within clauses is different. ... (30)

On the other hand $\mathrm{N}$ has the same order as D2, and I suspect that this is how Duncan learned it (31-32).

... in D1 he simply leaves in pursuit without comment, and in D2 and $\mathrm{N}$ he gets ready . . before leaving (33). 
Although he regards Neil's texts as authentic, ${ }^{23}$ Bruford has this to say about the collection: "[It] has been unduly neglected hitherto because of some fault found with later volumes, but the early volumes in particular contain much of great interest" (Bruford 1979:40). This "fault" does not appear to have been mentioned again in any of Bruford's subsequent publications, but it must have been of a relatively serious nature for the collection to have been "neglected." 24 Bruford and MacDonald (2003) were clearly unaware of any derivative relationship between Neil's text of Fear na h-Eabaid and Craig's: "[it is] fairly certain that both brothers learned the story virtually word for word by heart from their father" (453). Additionally, the manuscripts of Duncan and Neil's stories in the DJM collection generally show annotation in the form of motif numbers (see Figure 5 below), having been inserted probably by either Bruford or Donald Archie MacDonald. Such annotation is thus further evidence that the stories were considered authentic. However, if Bruford did have any suspicion concerning the origin of the items in Donald John's manuscripts, the issue was more extensive than he had suspected: the results from the current analyses (see \$3.2-3.3 below) suggest that Donald John was drawing from Craig's publications within the first $10 \%$ of his work. Furthermore, it can be demonstrated that he utilized printed work not only in what he claimed were transcriptions from his uncle, but in those he submitted in his father's name. Support for these assertions, as well as evidence for visual copying, will be provided in the sections below.

The data available from Duncan for a "thick corpus" approach — as advocated by Honko, who described it as "worth its weight in gold" (2000:21) - is thus greatly limited. Some of the stories attributed to him were collected only by Craig and Donald John. One also wonders whether any of Neil's narratives were taken down from him verbatim. Without these stories, we cannot investigate the variation in evidence between him and Duncan, a crucial source of information for reconstructing how they may have heard their stories in the first place.

However, before considering these topics further and providing additional evidence of the link between Donald John's manuscripts and printed sources, it will be useful to consider more fully the collector and his collection.

\subsubsection{Donald John MacDonald and His Collection}

Donald John MacDonald is described as having been a "harum-scarum, truant-playing teenager impatient to leave school at fourteen, having shown precious little sign of any academic bent" (MacDhòmhnaill and Innes 1998:vii). Despite his lack of obvious scholarly inclinations, he

23 In footnote 13 of Scottish Traditional Tales, Bruford says (1979:41): "Neil's text [of An Ceatharnach Caol Riabhach] ... . was most regrettably overlooked when we published Donald Alasdair Johnson's version of this tale [in Macdonald and Bruford 1970]."

${ }^{24}$ Another interpretation of this "fault" is that the later volumes of Donald John's work have as few as two or three words per line and are double spaced, contrasting sharply with his earlier writing style. It is a curious feature of his collection, and it could perhaps be explained by the way in which he was paid. A short piece in the first volume of Scottish Studies (Anonymous 1957) mentions that Donald John was "engaged on a voluntary, part-time basis" (14). If he had the same arrangement as other part-time collectors at the time, he would have received $£ 5$ per notebook of 96 pages (Sanderson 1953). He submitted 69 notebooks and, therefore, would have been paid-in today's currency (see http://www.measuringworth.com) - around $£ 18,000$ in total, or roughly $£ 3,500$ per year of engagement. 
published two books during his lifetime (MacDhòmhnaill 1974 and 1981), a number of articles and songs in the Gaelic periodical Gairm, and a short piece in Scottish Studies (Do. MacDonald 1957). He was also one of the most celebrated Gaelic poets of the twentieth century. His song Moladh Uibhist won him the Mod's Bardic Crown in 1948 (MacDhòmhnaill and Innes 1998:20-30), and he wrote a number of other celebrated songs in the language. He suffered as a German prisoner of war during WWII - details of which are published in his book Fo Sgàil a' Swastika ("Under the Shadow of the Swastika," MacDhòmhnaill 1974)—and afterwards returned to the croft of his youth in Peninerine, South Uist.

He was engaged on a casual basis by the School of Scottish Studies ${ }^{25}$ during the years 1953 and 1958, when he would have been in his mid-thirties. Calum Maclean encouraged him to record everything that his father said on "tape" (MacGillEathain 1954). Evidently, then, he had a tape recorder at some point, ${ }^{26}$ although there is only one trace of recordings made by him in the School's database. ${ }^{27}$ His manuscript collection is in 26 bound volumes in the Upper Library of the school, organized into 69 books. A large number of the pieces that he submitted were attributed to his father and uncle; there were over 1500 pages from Duncan alone (Hillers 2007; MacGillEathain 1954).

Bill Innes (MacDhòmhnaill and Innes 1998:viii) relates that Donald John and his sister Ann had essentially been raised by Neil, and had been closer to him than their father: Duncan was often away from home, apparently, due to the demands of the croft, his work as a mason, and his popularity as a storyteller. Donald John's use of Craig's work in the items ostensibly taken from Neil is thus perplexing.

Is it possible that Donald John did not fully understand the remit before him? His accession sheets-labels that he would have pasted into his notebooks before writing down the contributions of an informant ${ }^{28}$ - detail the date on which he collected each text and the particular individual from whom it came (see Figure 1 above). Additionally, he had a long association with the School of Scottish Studies (over five years), and such a remit would have presumably become evident during this time. Although it is not currently possible to locate any correspondence between Donald John and the School, the briefs given to other part-time and casual collectors around the same period make explicit the imperative to collect from oral sources, as well as for transcriptions to be a true reflection of recitations or recordings. Here is an excerpt from one of these briefs, a letter written by Professor Kenneth Jackson to a potential collector in Barra (Jackson 1951):

${ }^{25}$ The school was founded in 1951 at the University of Edinburgh.

${ }^{26}$ Allan Bruford himself was under this impression. (See note 13 above.)

${ }^{27}$ SA1956.167, relating to songs collected from Kate and Annie MacDonald in South Uist.

${ }^{28}$ A letter from Stewart Sanderson, Secretary-Archivist of the School, to a potential part-time collector of the same period says: "I expect Mr. Maclean [that is, Calum Maclean] has explained the system: a new label should be used for every new person from whom you collect information" (Sanderson 1953). 


\begin{abstract}
Mr. Calum Maclean of the School of Scottish Studies tells me that you would like to do some part time work collecting Gaelic oral traditions for us, [and] that he has explained what sort of thing we want. . . . We use a standard notebook of 96 pages, into which the collector transcribes his collections, either from Ediphone records or directly from the recital of the teller; and we pay $£ 5$ per notebook. If you are willing to undertake some work for us this summer, would you kindly let me know by return? Then I will send a couple of notebooks and some labels.
\end{abstract}

It is hard to imagine how Donald John would have not been aware that the School was interested in orally garnered material rather than that taken from published sources, even if they were from his father originally. The labels that he was given seem to make this awareness clear. However, at the moment, as there is no trace of correspondence with him, any assumptions about what he was or was not told, and what he took from it, belong to the realm of conjecture.

\title{
3.1.3 Evidence for Visual Copying in Fear na h-Eabaid: Weddings, Fires, and Textual Lacunae
}

At first glance, the connection between Craig's published texts and Donald John's manuscripts is obscured by the difference in the two writers' orthographical habits. Craig was a careful and consistent editor, presenting his texts in an orthographically conventional fashion for the most part, but also trying to convey the dialectal flavor of South Uist Gaelic. Donald John's orthographical practice - particularly his use of accents and punctuation-is irregular, but he does tend to be fairly even in his spelling, as unconventional as it is at times. Despite Craig's proficiency in written Gaelic, he was working in the days before word processors, and occasional irregularities are to be found. One of these inconsistencies involves the word banais ("wedding"), which occurs six times in Craig's version of Fear na h-Eabaid ${ }^{29}$ : twice as banais (on pages 23 and 24) and four times as bainis (on pages 26, 27, and twice on 29). Curiously, Donald John makes the identical switch in the same places. The first two figures below show the parallel use of banais: $^{30}$

Figure 2: MacDhòmhnaill and Craig 1950:24, banais (line 4, word 3)

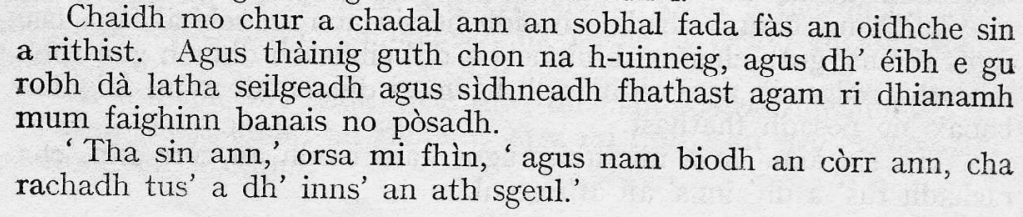
a rithist. Agus thàinig guth chon na h-uinneig, agus dh' éibh e gu robh dà latha seilgeadh agus sidhneadh fhathast agam ri dhianamh mum faighinn banais no pòsadh.

'Tha sin ann,' orsa mi fhin, 'agus nam biodh an còrr ann, cha rachadh tus' a dh' inns' an ath sgeul.'

$$
24
$$

${ }^{29}$ MacDhòmhnaill and Craig 1950:17-29. For ease of reference, within §3.1.3-3.1.4 this work will often be denoted as "Craig" or "Craig's version."

${ }^{30}$ Cf. MacDhòmhnaill and Craig 1950:23 and DJM-N:3553. 
Figure 3: DJM:3557, banais (line 4, word 1)

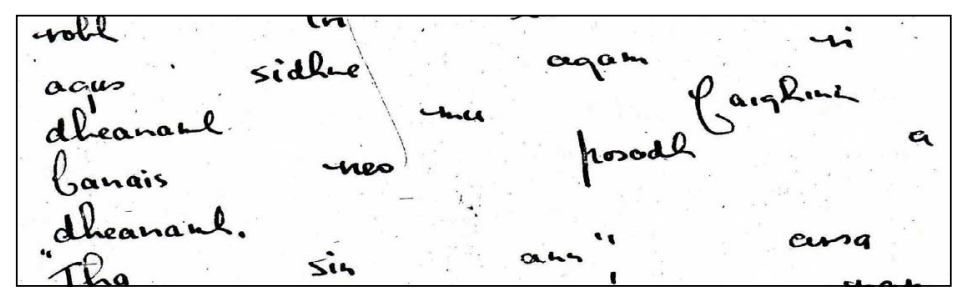

The difference in the syntax and vocabulary here is curious ${ }^{31}$ and seems to indicate conscious modification (see $\$ 3.1 .4$ below for discussion and further examples). The next two figures show the parallel use of the misspelling bainis: ${ }^{32}$

Figure 4: MacDhòmhnaill and Craig 1950:26, bainis (line 2, word 3)

dhomh gu robh latha seilgeadh agus sidhneadh agam ri dhianamh
mum faighinn bainis no posadh.' '
'Tha sin ann,' orsa mi fhin, 'agus nam biodh an còrr ann, cha
rachadh tus' a dh' inns' an ath sgeul.'
'Cha bu lughaide do chuid-sa a gheasachd an eilein sin,' ors am
fear eile, 'mura cuirinn-sa na geasaibh ud ort, chuireadh fear eil'
ort iad.'
26

Figure 5: DJM-N:3557, bainis (line 4, word 1) with motif annotation on right

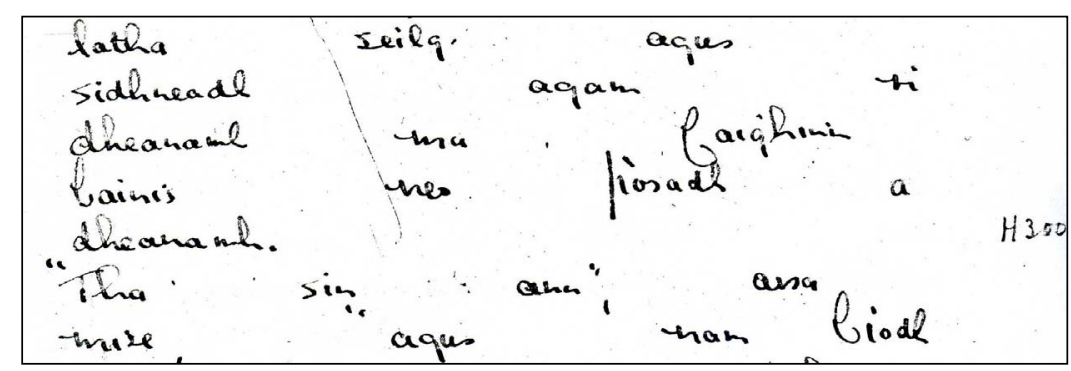

Spelling fluctuation in a handwritten document is not unusual, especially for a language that has undergone a number of orthographical iterations over the years. However, it is difficult to envisage how chance alone could account for Donald John's spelling of this word fluctuating in parallel with Craig in the six places that it occurs in the text. It is important to emphasize that

${ }^{31}$ Donald John's reads (original formatting): “Chaidh mo chur a chadal an oidhche sin a rithist ann a sabhal fada thàinig an guth a dh' ionnsaigh na h' uinneig, agus dh' eubh e gun robh trì latha seilge agus sìdhne agam ri dhèanamh mu faighinn banais neo pòsadh a dhèanamh. 'Tha sin ann,' arsa mi fhìn, 'agus nam biodh an còrr ann cha rachadh tusa a dh' innse an ath-sgeoil."”

32 This may be an Irishism, but bainis is also given as an alternative form in Dwelly's dictionary (2001 [1911]:60; my appreciation to Dr. Wilson McLeod for this information). Two further parallel examples are found at MacDhòmhnaill and Craig 1950:27, 29 and DJM-N:3573, 3582. 
K. C. Craig published Sgialachdan Dhunnchaidh a number of years before Donald John began work on his manuscripts. This fluctuation is plain evidence of visual copying. While this is one instance of parallel inconsistency, the next example is a common artifact of transcriptive practice.

Any person who has done a significant amount of transcription from a printed source will be familiar with the phenomenon of unconsciously moving up or down to a neighboring line of text and copying the wrong words. Donald John seems to have experienced this on at least one occasion, as can be seen in the following example:

Figure 6: Donald John MacDonald transcribing the wrong line of text from Craig (from DJM: 3564)

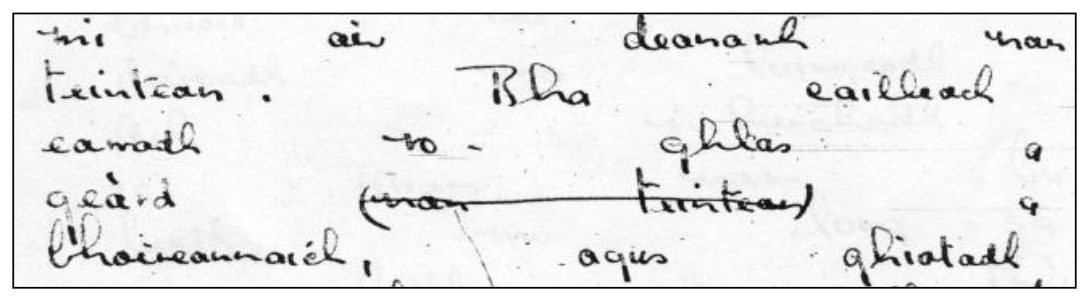

The following is a printed version of the excerpt (original formatting):

. . mi air deanamh nan teintean. Bha cailleach earradh ro- ghlas a geàrd (nan teintean) a bhoireannaich, agus ghiotadh. ...

If we look in the original, we see that the words he has crossed out-nan teintean 33 ("of the fires")- are immediately above those that he had intended to write down:

Figure 7: Example (MacDhòmhnaill and Craig 1950:26) showing nan teintean immediately above $a$ 'bhoireannaich

Dh' fhalbh mi mach agus thòisich mi air dianamh nan teintean Bha cailleach earradh ro ghlas a' geàrrd a' bhoireannaich ; agus ghiotadh $i$ mach, agus dhianadh i dà theine ma 'n aon fhear riumsa

This is additional evidence of Donald John actively copying from Sgialachdan Dhunnchaidh.

As a third and final example of visual copying, Donald John omits two episodes of the tale that are in the other versions taken from Duncan. These episodes pertain to the second and third times that the wife of Fear na h-Eabaid is abducted and subsequently rescued, and they run from page 22, paragraph 6, to page 23, paragraph 11, in Craig's version. The wording in each

33 This word is also indicative of a derivative relationship between the texts, as it can be spelled with one or two $n$ 's. Teintean is the spelling in Craig's version and in DJM-N, as well as in the version of McClements, which predates them and is unpublished. CIM47, JLC, and CIM53, on the other hand, all have teinntean. Judging by the Dice coefficient results (Table 4) that find McClements' text to be the most dissimilar to the others, it is unlikely that either Craig's version or DJM-N were derived from or influenced by it in any way. 
episode is quite similar, and occasionally formulaic, explaining how such a lacuna could have easily occurred. The following quote is from MacDhòmhnaill and Craig 1950 (page 22) and the text that is crossed out shows the beginning of the gap in DJM-N (original formatting preserved):

. . . agus sheòl mi mo shleagh fhìn airsan, agus bhuail mi ann an àird a chlèibh e, agus thuit e. Greas mi ga ionnsaigh, agus mharbh mi e. Agus thug mi liom am boireannach air ais dhachaidh dha 'n Tiobard; agus ma bha biadh no deoch aca ri ghabhail, bha iad air an gabhail mun do ràini' mise.

. . . and I sailed my own spear at him, and I struck him in the top of his ribcage, and he fell. I hurried toward him, and I killed him. And I took the woman with me back home the Fountain; and if there was food or drink to have, that they had consumed it before I arrived.

This lacuna lasts for approximately a page and three paragraphs, omitting 730 words of Craig's text. The similarity of the language on either side of the gap is shown by the following, which is taken from Craig at the point that Donald John's text resumes (MacDhòmhnaill and Craig 1950:23):

Agus thug mi am boireannach liom dhachaidh.

Ach thuirt mi rium fhìn, cho math 's gun robh an Tiobard, gum fòghnadh siod dhomhsa dhith; agus dh' fhalbh mi fhìn agus an nighean agus Gruagach an Fhéidh. ...

And I took the woman home with me.

But I said to myself, as good as the Fountain is, that I've had enough; and I myself left [with] the girl and the Woman of the Deer....

This is how the text appears in DJM-N (3552), with * indicating the 730-word lacuna:

... agus sheòl mi mo shleagh fhìn airsan, agus bhuail mi ann an àird a chlèibh e, agus leag mi e. Ghreas mi ga ionnsaigh agus mharbh mi e. Agus thug mi am boireannach leam dhachaidh. * Ach thuirt mi rium fhìn, cho math 's ga robh an Tiobard, gum fòghnadh sud dhòmhsa dhi, agus dh' fhalbh mi fhèin agus a nighean agus Gruagach an fhèidh. ...

... and I directed my own spear at him, and I struck him in the top of his ribcage, and I felled him. I hurried towards him and I killed him. And I took the woman home with me. * But I said to myself, as good as the Fountain is, that I've had enough, and I myself left [with] the girl and the Woman of the Deer....

The gap did not escape Bruford (1979:34), but he rationalized it by saying that it might have been a reflection of the way in which their father had originally told the tale; Duncan 
himself was in error by triplicating the episode. ${ }^{34}$ To bolster his interpretation, Bruford observes that the other orally collected versions of the story have only one "stealing" episode. However, there appears to be sufficient evidence to reject, or at least temper, this interpretation now on the grounds that Craig's published tale formed the basis of Neil's text. Perhaps Donald John himself omitted these episodes because Neil had indicated that they were superfluous. This explanation is possible, but it would mean that Neil was complicit in the copying, which seems unlikely. A more straightforward explanation is that Donald John lost his place in the book, or that he regarded the episodes as redundant and decided to omit them.

In this section, I have not yet provided the strongest evidence of a derivative relationship between the two texts: the proliferation of long, identical passages that are shared between them (but see $\$ 3.2$ and 3.3 below). There is little chance that such similarities, or any of the textual features delineated above, could have occurred without Donald John MacDonald visually scanning the tale of Fear na h-Eabaid published in Sgialachdan Dhunnchaidh. Furthermore, as Neil's version (DJM-N) has more lexical crossover than any of the others with Craig's version (see Table 4 and Table 5) and they are, in fact, the two most concordant texts, there are very firm grounds for concluding that Donald John took Neil's text from Craig's work. Having established this likely source, it remains to be seen how Donald John transformed that source and then convinced several scholars that the texts he provided from Neil and Duncan were taken down from their recitation and were independent from other versions.

\subsubsection{Tweaking the Text: Differences between Craig's and DJM's Versions of Fear na h-Eabaid}

This section will detail the most significant ways in which Donald John's text of Fear na $h$-Eabaid differs from Craig's. As the evidence indicates that visual copying took place, it follows that the differences described here are a product of conscious modification. An examination of the texts reveals two broad types of change: lexical and syntactic.

\subsubsection{Lexical Change}

The lexical changes can be categorized into augmentation, omission, synonymic replacement, the expansion of pronominal referents, and the alteration of pronominal emphasis. Augmentation is being used here to refer to the insertion of extra words into a phrase. In DJM-N, these insertions usually take the form of filler words carrying little or no extra semantic information. This is one of the ways in which DJM-N differs from the variants that are independent from Craig's version. Extra words in the independent variants often feature additional or different information, while those in DJM-N generally do not: a parasitic version is limited by the semantic borders of the original. At its simplest, augmentation in DJM-N takes the form of the insertion of agus ("and"):

\footnotetext{
${ }^{34}$ Of course, the convention for triads runs deep in folklore around the world (see Lease 1919).
} 
Example 1: Lexical change (augmentation using agus [“and"])

\begin{tabular}{|ll}
\hline Craig (17) & DJM-N (3527) \\
Cò $[$ am $]$ fear thusa $\ldots$ & Agus cò am fear thusa ... \\
Who are you ... & And who are you ...
\end{tabular}

In addition to agus, Donald John's version in Example 1 also includes the determiner am ("the"), which was elided in Craig's version, presumably to reflect spoken Gaelic. In speech, elision such as this is phonologically motivated and definiteness would be understood. Another common augmentation in DJM-N is the use of dh'fhalbh NP agus ("NP went and ..."):

\section{Example 2: Lexical change (augmentation using dh'fhalbh ["went"])}

\section{Craig (20)}

$\ldots$ agus ghabh mi an coinneamh na gruagaich a bha tighinn.

... and I squared off with the hairy giant that was coming.

\section{DJM-N (3543)}

... agus dh'fhalbh mi agus ghabh mi an coinneamh na gruagaich a bha tighinn.

and I went and I squared off with the hairy giant that was coming.

The only difference between Craig's version and DJM-N in Example 2 is the insertion of the phrase dh'fhalbh mi agus; this strategy occurs another five times in the text.

Other common filler words in DJM-N include discourse particles and conjunctions such as ach ("but"), an-dà ("well"), a-nis ("now"), an-sin, ("there/then"), an-seo ("here/now"), ge-tà ("however"), ma-tà ("then" [that is, "if it is the case"]), an uair sin ("then" [temporal]), and intensifiers such as glè ("very") and gu math ("well/very").

Omission is rare, and may be unintentional, such as in the case of the lacuna mentioned in \$3.1.3 above and in the following example, which is at the end of the tale and results in a nonsensical proposition in DJM-N:

\section{Example 3: Lexical change (omission)}

Craig (29)

Cha robh sìon a chruinnich Macan Òg na Grèige airson na bainnse aige fhèin nach do dheònaich e nis a chosg ri bainis a dhèanamh dhomhsa.

There wasn't anything that the Young Son of Greece gathered for his wedding that he wasn't now willing to spend in order to make a wedding for me [EMPH].

\section{DJM-N (3582)}

Cha robh [omission] Macan òg na Greige airson na bainnse aige fhèin nach do dheònaich e a chosg a nis airson bainis a dheanamh dhomhsa.

* The Young Son of Greece wasn't for his wedding that he wasn't now willing to spend in order to make a wedding for me [EMPH]. 
As can be seen, the omission in DJM's text renders the sentence unintelligible. It may be simply an unconscious by-product of visual copying. ${ }^{35}$

There are also numerous cases of synonymic replacement and the deployment of semantically equivalent phrases, three examples of which can be discussed here.

Example 4: Lexical change (synonymic replacement)

Craig (29)

Nuair a bha e treis a' feitheamh, ...

When he had been waiting a while,...

\section{DJM-N (3583)}

Nuair a bha e greis a' feitheamh, ...

When he had been waiting a short while, ...

Example 4 is the simplest of the three, with treis ("a while") being replaced by the closely related word greis ("a short while"). Example 5 is slightly more complicated, as the usage of the closely related phrase timcheall ("around") for mun cuairt ("about") also involves a change in syntax. The subject of the second clause in DJM-N is oblique, encoded by the prepositional pronoun agam ("at me"). As discussed further below, this modification is probably an example of Donald John being forced to use marked ${ }^{36}$ syntax to avoid the wording of the original, which is more natural by far.

Example 5: Lexical change (replacement using semantically equivalent phrase)

Craig (25)

Nuair a ràinig mi, cha robh mi faicinn duine mun cuairt.

When I arrived, I wasn't seeing a person [anybody] around.

\section{DJM-N (3560)}

Nuair a ràinig mi cha robh aon duine ri fhaicinn agam timcheall an àite.

When I arrived, I couldn't see one person around the place. [Lit. "When I arrived, not one person was to be seen by me around the place."]

Finally, in Example 6 we come to the most verbose instance of this type of modification in Fear na h-Eabaid. All of the other versions of the story (JLC, CIM47, CIM53, and McClements) resemble the straightforward simplicity of Craig here, but Donald John's rendering borders on the pleonastic:

35 This passage also contains the third incidence of the misspelling of banais, a phenomenon that was mentioned above.

36 Trask defines a marked form as "less central or less natural than a competing one on any of various grounds, such as lower frequency, more limited distribution, more overt morphological marking, greater semantic specificity or greater rarity in languages generally" (1995:167). 
Example 6: Lexical change (replacement using semantically equivalent phrase)

\section{Craig (28)}

Dh'atharraich sinn aodaichean.

We switched clothes.

\section{DJM-N (3575)}

Chuir esan dheth a chuid aodaich fhèin agus chuir mise dhiom m' aodach fhìn agus dh'atharraich sinn ar cuid aodaich mar sin.

He put off his own clothes and I put off my own clothes and we switched our clothes like that.

The next type of modification is the expansion of pronominal referents, seen in the following examples. Such expansion involves the use of a full noun phrase in the place of a pronoun. Essentially, these are cases of augmentation, as the expansion adds no additional information to the text.

Example 7: Lexical change (expansion of pronominal referents)

Craig (28)

... rinn $\mathbf{i}$ lasgan mòr gàire.

... she made a big laugh.

\section{DJM-N (3576)}

... rinn a' chailleach lasgan mòr gàire.

... the old woman made a big laugh.

As seen in Example 7 above, $i$ ("she") is replaced with $a$ " chailleach ("the old woman"). The rest of DJM-N is identical to Craig's version. Example 8 is similar, with $e$ ("he") being replaced by Fear na h-Eabaid ("the Man of the Habit"):

\section{Example 8: Lexical change (expansion of pronominal referents)}

\section{Craig (18)}

Agus thòisich $\mathbf{e}$ air dèanamh an eallaich.

And he began to make the load.

\section{DJM-N (3529)}

Agus thòisich Fear na h-Eabaid air dèanamh an eallaich.

And the Man of the Habit began to make the load.

These examples all involve marked language being used in the place of the more natural options that are already in the source text (Olsson 2009:31-32):

The copyist cannot use the same lexicon as the source, but has to adapt words and phrases found in the original. . . [ [He or she] has to avoid the very words which come most naturally and which, probably, are already in the text being copied. . . . The result, very often, is that [his or her] vocabulary choices are to a greater or lesser extent, less than ideal. 
From the examples in $\$ 3.1 .4 .2$ below (and Example 5 above), it appears that copyists also occasionally resort to marked syntax. This probably occurs for a similar reason: it is an attempt to avoid the simple modes of expression already present in the original.

To conclude this section, the way in which a pronoun receives emphasis is also seen to differ between Craig's version and DJM-N. In English, we generally emphasize pronouns and other words through pitch, or loudness, or both. In Gaelic, this emphasis is normally achieved through suffixation ( $e$ ["he/him"] $>$ esan ["he/him"]: $e+$ san [emphatic suffix]), or by making the NP reflexive (for example, mi ("I/ me") > mi fhin ("myself"). Where Craig's version has one form of emphasis, DJM-N often uses the other:

Example 9: Lexical change (alteration of pronominal emphasis)

\section{Craig (26)}

"Tha sin ann," arsa mi fhìn. ...

"That is the case," I myself said. ... [Lit. "That is in it. ..."]

\author{
DJM-N (3568) \\ “Tha sin ann”, arsa mise.... \\ "That is the case," I (EMPH) said. . . . \\ [Lit. "That is in it. ..."
}

In Example 9, the only difference is that Craig's text has mi fhin while DJM-N has mise; Craig uses reflexive emphasis while DJM-N uses emphatic suffixation.

The vast majority of lexical change to be seen in Donald John's version of Fear na hEabaid involves some kind of augmentation. As mentioned above, these additions provide little or no additional information to the text; they merely make it appear to be distinct from the original. The next section will explore another type of modification, that involving changes in word order.

\subsubsection{Syntactic Change}

Most of the syntactic changes evident in DJM-N consist of preposing adverbials and other elements that are relatively unconstrained in Scottish Gaelic syntax. In general, this type of change is not overly abundant in the text compared to instances of lexical change, particularly augmentation. In Example 10 the only change to be seen is the shifting of the adverbial an seo ("here") to occur before the main verb chuala ("heard"):

Example 10: Syntactic change (position of adverbial)

\section{Craig (26)}

Ach chuala sinn an seo a' chailleach earradh ro ghlas ag èigheach dha na fuamhairean. ...

But we heard here the hag with the very grey mantle yelling to the giants. ...

\section{DJM-N (3566-67)}

Ach an seo chuala sinn a' chailleach earradh ro ghlas ag èigheach dha na famhairean. ...

But here we heard the hag with the very grey mantle yelling to the giants... . 
The rest of the clause is identical in the two sources. Example 11 works similarly, in that the clause headed by the narrative verb arsa ("quoth/said") is shifted to a new position. As with adverbials, this type of clause is fairly moveable in Gaelic syntax:

Example 11: Syntactic change (position of narrative verbal clause)

$\begin{array}{ll}\text { Craig (26) } & \begin{array}{l}\text { DJM-N (3568) } \\ \text { "Ach co dhiubh," arsa Fear na h-Eabaid, "fhuair sinn "Ach co-dhiubh, fhuair sinn dhachaidh," arsa Fear na } \\ \text { dhachaidh. ..." }\end{array} \\ \begin{array}{ll}\text { "But anyway," said the Man of the Habit, "we got "But anyway, we got home," said the Man of the } \\ \text { home. ..." }\end{array}\end{array}$

The narrative clause arsa Fear na h-Eabaid has been postposed in DJM and does not break up the reported speech as it does in Craig's version. As in many of the previous examples, the rest of the utterance is the same.

Occasionally, cases of paraphrasing can be found that involve a change in syntax, depending on the particular idiom employed:

Example 12: Syntactic change (paraphrasing)

\begin{tabular}{|ll}
\hline Craig (29) & DJM-N (3580) \\
"Leigeadh a staigh mi. ..." & "Chaidh mi fhìn a leigeil a staigh. ...” \\
"I was let in. ..." & "I myself was let in....” \\
& {$[$ Lit. "My-REFL letting in went. ..."] }
\end{tabular}

There are various ways of decreasing valence in Scottish Gaelic (see Lamb 2008:242-44), resulting in passive and impersonal expressions. While Craig uses a morphological passive, with the main verb incorporating a passive suffix, DJM-N has a periphrastic equivalent. The place adverbial a-staigh ("in") is shifted to the end of the utterance in DJM-N, and the main verb is in a medial position through its coupling to the auxiliary chaidh ("went"), which needs to be clauseinitial. Finally, the pronoun is reflexive, whereas it is unmarked in Craig's version.

The last example (Example 13) shows an instance of clause order shift:

Example 13: Syntactic change (clause order modification)

$\begin{array}{ll}\text { Craig (19) } & \text { DJM-N (3536) } \\ \begin{array}{l}\text { Agus chaidh Murchadh mac Brian, nuair a rug e } \\ \text { air, na dheagh fhaireachadh. ... }\end{array} & \begin{array}{l}\text { Ach nuair a rug Murchadh mac Brian air } \\ \text { chaidh e na dheagh fhaireachadh.... }\end{array} \\ \begin{array}{ll}\text { And Murdo son of Brian went, when he grabbed } \\ \text { it, into a good feeling.... }\end{array} & \begin{array}{l}\text { But when Mugmented] } \\ \text { went into a good feeling. ... [integrated] }\end{array}\end{array}$


In Craig's text, the temporal clause nuair a rug e air ("when he grabbed it") is nested medially within the larger clause agus chaidh Murchadh mac Brian na dheagh fhaireachadh ("and Murdo son of Brian went into a good feeling"). This type of fragmentation is natural in spontaneous speech and follows from the logic of information structure (see Chafe 1982; Miller and Weinert 1998). The DJM-N text, on the other hand, preposes the temporal clause and resembles the integrated syntax of typical written language.

To summarize, there are a number of ways in which Donald John modified his text of Fear na h-Eabaid. The most frequent type of modification by far is lexical augmentation, characterized here by the insertion of words with little additional semantic sense. Ultimately, the options for altering the source text are limited by the semantic boundaries of the original and the lexicon employed therein. Syntactic adjustments are in evidence, but are less frequent. By and large, these modifications involve shifting the placement of adverbials and other syntagms that have relatively few syntactic constraints in the Gaelic language.

Having established that visual copying is the only explanation for Donald John MacDonald's text of Neil being closer to Craig's text of Duncan than are any of Duncan's other versions themselves, it remains to be seen how many other texts show the same signs of dependence. A further four tales published by Craig will now be explored using the Dice coefficient and textual analysis in order to determine whether or not Fear na h-Eabaid is an isolated case. As we shall see, the evidence strongly suggests that Donald John made extensive use of Craig's work, both in texts he submitted as recitations of his uncle Neil and in those attributed to his father.

\subsection{An Analysis of Four Other Texts Submitted by Donald John MacDonald and Their Relationship to the Work of K. C. Craig}

\subsubsection{Sgeulachd an Tuairisgeil Mhòir}

Sgeulachd an Tuairisgeil Mhòr ("The Story of the Big 'Made Up Tale"') was a popular hero tale much in the same vein as Fear na h-Eabaid, with which it shares an abundance of antiquated, formulaic language. Unlike Fear na h-Eabaid, however, there are no old manuscript versions of it in evidence, indicating that it was probably not a literary romance per se. All five available sources were involved in the present analysis (see Table 1 above). The transcription of John Lorne Campbell's 1950 recording was done by the current author. Samples were gathered from both the very beginning and end of the tale. ${ }^{37}$ Unlike the Fear na h-Eabaid analysis, there is a version attributed to Duncan in Donald John's manuscripts (DJM-D), but there is only one from Maclean and none from McClements:

37 Samples from the beginning and end are by definition naturally selected due to the presence of predetermined boundaries, thus minimizing the possibility of researcher bias. (Of course, one boundary is still determined by the researcher, but in this case it has been defined by word-count limits.) Additionally, as will be argued below, if a copyist of a long manuscript is trying to avoid detection, the beginnings and ends will probably be attended to in a more rigorous manner than the middle section. Therefore, if the level of intersection between two texts at the beginning and end is markedly high, it is even more likely that visual copying occurred. 
Table 6: Dice values for the beginning of Sgeulachd an Tuairisgeil Mhoir ${ }^{38}$

\begin{tabular}{|ccc|}
\hline File 1 & File 2 & Relation \\
\hline Craig & DJM-D & 0.90 \\
DJM-D & DJM-N & 0.89 \\
Craig & DJM-N & 0.86 \\
Craig & JLC & 0.72 \\
CIM & DJM-D & 0.72 \\
DJM-D & JLC & 0.72 \\
JLC & DJM-N & 0.71 \\
CIM & DJM-N & 0.70 \\
CIM & Craig & 0.69 \\
CIM & JLC & 0.68 \\
\hline
\end{tabular}

The relation values clearly show that there is a close intertextual relationship between Craig, DJM-N, and DJM-D. While the other texts have some crossover, none of them evinces the same degree of similarity. The following examples ${ }^{39}$ illustrate these tendencies:

Craig: Dh' fhalbh Mac Rìgh Èreann dhachaidh, e fhèin 's am boireannach. Agus cha robh moit ann ach a' mhoit a bha air athair nuair a ràinig a mhac le a leithid sin do bhoireannach ciatach.

DJM-N: Thill mac Rìgh Ėireann dhachaidh, e fhèin agus am boireannach, agus cha robh moit ann ach a' mhoit a bha air Rìgh Eireann nuair a ràinig a mhac dhachaidh le a leithid seo do bhoireannach brèagha.

DJM-D: Dh' fhalbh mac Rìgh Ėireann dhachaidh, e fhèin agus am boireannach, agus cha robh moit ann ach a' mhoit a bha air athair nuair a ràinig a mhac dhachaidh le a leithid seo do bhoireannach ciatach.

CIM: Agus dh' fhalbh Mac Rìgh Èreann dhachaidh, agus am boireannach aige, agus 's ann a bha moit mòr air athair, 'n uair a ràinig a mhac dhachaidh agus a leithid seo a bhoireannach mòr, ciatach, brèagha còmhla ris. ...

JLC: Dh' fhalbh Mac Rìgh Èireann dhachaidh agus am boireannach eireachdail a bha ann an seo aige agus cha robh moit ann ach a' mhoit a bhiodh air athair nuair a chunnaic e a mhac a' tighinn dhachaidh le a leithid seo a bhoireannach mòr ciatach.
The son of the King of Ireland went home, himself and the woman. And there was no pride but the pride that was on a father when his son arrived with such a beautiful woman.

The son of the King of Ireland returned home, himself and the woman, and there was no pride but the pride that was on the King of Ireland when his son arrived home with such a lovely woman.

The son of the King of Ireland went home, himself and the woman, and there was no pride but the pride that is on a father when his son came home with such a beautiful woman.

And the son of the King of Ireland went home, and the women with him, and it was that there was great pride on his father, when his son came home with such a lovely, beautiful, big woman along with him. . . .

The son of the King of Ireland went home and this handsome woman here with him and there was no pride but the pride that would be on a father when he saw his son coming home with such a large, beautiful woman.

\section{${ }^{38}$ Within $\$ 3.2 .1$ “Craig” is used to refer to MacDhòmhnaill and Craig 1950:59-72.}

39 These and the following examples are given in their standardized orthography, unless otherwise stated. No attempt was made for the examples to conform exactly to GOC, but rather for them to be in line with each other, using GOC as a reference point. All English translations provided are by the current author. 
The language is remarkably consistent across the versions, but the first three texts depart from CIM and JLC in specific ways. Craig, DJM-N, and DJM-D all have a variant of a motion verb + mac Righ dhachaidh (e. g., "the king went home"), and then a right detached phrase- $e$ fhein agus am boireannach ("he himself and the woman") - while CIM and JLC use the cosubordinate agus (see Lamb 2008:263-64). In the second sentence ${ }^{40}$ of Craig, both CIM and JLC are more verbose in describing the boireannach ("woman"), while Craig, DJM-N, and DJM-D use a single adjective — either ciatach or brèagha, both meaning "beautiful."

If we examine the Dice values for the end of the text, the same patterns obtain:

Table 7: Dice values for the end of Sgeulachd an Tuairisgeil Mhòr

\begin{tabular}{|ccc|}
\hline File 1 & File 2 & Relation \\
\hline Craig & DJM-N & 0.88 \\
Craig & DJM-D & 0.88 \\
DJM-D & DJM-N & 0.86 \\
CIM & JLC & 0.69 \\
Craig & JLC & 0.69 \\
JLC & DJM-N & 0.68 \\
CIM & Craig & 0.66 \\
CIM & DJM-N & 0.66 \\
DJM-D & JLC & 0.65 \\
CIM & DJM-D & 0.65 \\
\hline
\end{tabular}

Again, Craig, DJM-N, and DJM-D form a triad, with a marked gap between their collective Dice values and those of the other texts. One would expect that Neil's text would be the most dissimilar to the others, as those texts all derive from Duncan, a separate individual, but instead it is actually at the top of the table. Additionally, as mentioned before in relation to the Fear na h-Eabaid texts, DJM's texts are more temporally distant from Craig than CIM or JLC. One would expect the latter two to be more similar to Craig due to their relative contemporaneousness. Here are some textual examples, followed by a table (Table 8) summarizing some of the different features present:

40 One might argue with the applicability of the notion of "sentence" to an oral text (see Halliday 1989:66; Miller and Weinert 1998:32-71). However, as Neil and Duncan's texts are assumed to be based upon Craig-a publication evincing punctuation-it seems felicitous to deploy it in this context. 
Craig: Dh' fhalbh e dhan bheinn sheilg agus, nuair a ràinig e an cnocan far na dh' fhàg e an duine fo na geasaibh, cha robh ann ach torradan chnàmh agus fòlach air fàs mun timcheall.

DJM-D: Dh' fhalbh Mac Rìgh Èireann dhan bheinn sheilg agus nuair a ràinig e taobh a' chnuic far na dh' fhàg $e$ an duine fo na geasaibh cha robh ri fhaicinn ann ach torradan beag chnàmh agus fòlach air fàs timcheall orra.

DJM-N: Dh' fhalbh Mac Rìgh Èireann agus chaidh e a mach dhan bheinn sheilg. Nuair a ràinig e air cnocan far na dh' fhàg e an duine fo na geasaibh, cha robh ann ach torradan chnàmh agus fòlach a' fàs mun timcheall.

CIM: Dh' fhalbh Mac Rìgh Èireann agus an fhàlairidh, agus ràinig e an dearbh chnocan, air a robh e fhèin, agus an Tuairisgeul Òg a' cluichd air an tàileasg, agus cha robh ann an sin ach cnàmhan geala agus fòghlach gorm a' fàs mun timcheall.

JLC: Leum e ann an glac na diollaid agus mharcraich e dhan a' cheart sgroban air an robh e uaireigin an tsaoghal ag iomairt air an tàileasg. Agus cha robh sìon ann an sin ach tòrr fòlaich agus cnàmhan geala thall 's a bhos air fheadh, far na dh'fhàg e an duine.
He went to the hunting hill and when he arrived at the hillock where he left the man under spells, there was only a heap of bones with manured grass growing around them.

The son of the king of Ireland went to the hunting hill and when he arrived at the hill where he left the man under spells, all that could be seen was a heap of bones with manured grass growing around them.

The son of the King of Ireland left and he went out to the hunting hill. When he arrived on a hillock where he left the man under spells, there was only a heap of bones with manured grass growing around them.

The son of the King of Ireland and the palfrey left and they arrived at the exact hillock, on which he himself and the Young Tuairisgeul had played chess, and all there was there was white bones and green manured grass growing around them.

He leapt into the catch of the saddle and he rode to the exact mound on which he once upon a time had played chess. And there was nothing there but a lot of manured grass and white bones here and there throughout, where he had left the man.

Table 8: Feature list for the end of Sgeulachd an Tuairisgeil Mhoir

\begin{tabular}{|l|lllll|}
\hline Features & Craig & DJM-D & DJM-N & CIM & JLC \\
\hline $\begin{array}{l}\text { falbh ... dhan bheinn sheilg } \\
\text { fàlairidh }\end{array}$ & $\checkmark$ & $\checkmark$ & $\checkmark$ & & \\
$\begin{array}{l}\text { duine fo na geasaibh } \\
\text { cnoc(an) } \\
\text { tàileasg } \\
\text { torradan chnàmh } \\
\text { cnàmhan geala }\end{array}$ & $\checkmark$ & $\checkmark$ & $\checkmark$ & & $\checkmark$ (implied) \\
\hline & $\checkmark$ & $\checkmark$ & $\checkmark$ & $\checkmark$ & sgroban \\
& & $\checkmark$ & $\checkmark$ & & $\checkmark$ \\
\hline
\end{tabular}

As shown in Table 8, Craig, DJM-D, and DJM-N parallel each other in ways that the other two do not. All three share the phrase dh' falbh ("went") + subject (e ["he"] or mac Righ Eireann ["son of the King of Ireland"]) + dhan bheinn sheilg ("to the hunting hill"). DJM-N has the intermittent phrase agus chaidh e a mach ("and he went out"), but this is a form of augmentation, as discussed in \$3.1.4.1 above. Additionally, these three versions also have the phrases duine fo na geasaibh ("man under spells"), cnoc(an) ${ }^{41}$ ("hill[ock]")—shared with CIMand torradan chnàmha ("heap of bones"). On the other hand, CIM and JLC go together in hill”).

${ }^{41}$ Cnuic is the genitive singular form of cnoc and -an is a diminutive masculine ending, thus cnocan ("little 
mentioning the fàlairidh ("palfrey") (implied in JLC via mharcraich ["ride"] and diollaid ["saddle"]), tàileasg ("chess"), and cnàmhan geala ("white bones"). Considering the dates of their collection, we would expect DJM-D and DJM-N to evince at least as close a textual relationship with CIM and JLC as the one they have with Craig, but this is not the case. The textual evidence and relation values indicate a parasitic relationship between Donald John MacDonald's texts and Craig's published version.

\subsubsection{Conall Gulban}

Eachtra Chonaill Gulban ("The Adventure of Conal Gulban") was perhaps the most popular of the Gaelic romances. No fewer than 54 versions have been found in the Gaelic manuscripts of Scotland and Ireland (Bruford 1963-65:4). The same five sources were available for this tale as for Sgeulachd an Tuairisgeil Mhoir. As the Dice coefficient results for the end of Sgeulachd an Tuairisgeil Mhoir were consistent with the beginning, it seemed reasonable to analyze only the beginning of Conall Gulban. The following table presents the Dice coefficient results for this data:

Table 9: Dice coefficient results for the beginning of Conall Gulban ${ }^{42}$

\begin{tabular}{|ccc|}
\hline File 1 & File 2 & Relation \\
\hline Craig & DJM-D & 0.93 \\
DJM-D & DJM-N & 0.90 \\
Craig & DJM-N & 0.88 \\
CIM & Craig & 0.70 \\
DJM-D & JLC & 0.70 \\
CIM & JLC & 0.69 \\
CIM & DJM-D & 0.69 \\
JLC & DJM-N & 0.68 \\
Craig & JLC & 0.67 \\
CIM & DJM-N & 0.66 \\
\hline
\end{tabular}

Once again, the texts of Craig and Donald John MacDonald (DJM-N and DJM-D) form a group. There is a clear gap between the relation values of these texts and those of CIM and JLC. It is interesting to note that CIM and JLC, which were collected a mere three years apart from one another and were both transcribed from recordings, have a relation value of 0.70 . As will be discussed in $\$ 3.4$ below, this is the relation value that tends to obtain from two independent versions of Duncan's tales. But Neil's text (DJM-N), when compared to Craig's transcription of Duncan (referred to here as "Craig"), has a relation value 0.18 higher and is thus aberrant; it was from a separate individual and recorded eleven years later. Some textual examples of these relationships appear below, followed by an analysis:

\footnotetext{
${ }^{42}$ Within $\$ 3.2 .2$ "Craig” is used to refer to MacDhòmhnaill and Craig 1950:45-58.
} 
Craig: $\mathrm{Gu}$ dè ach a ghabh an Rìgh ceum sìos rathad glinne bha taobh shìos dhe. Chunnaic e brugh beag do thaigh ann an sin. Agus bha e cho eòlach air a' ghleann 's a bha e air a leth làimh 's air a leth chois, agus ar leis nach fhaca e taigh riamh ann.

DJM-D: Agus gu dè ach a ghabh an Rìgh ceum sìos rathad glinne a bha an taobh shìos dhe, agus chunnaic a brugh beag do thaigh ann an sin. Agus bha e cho eòlach air a' ghleann 's a bha e air a leth-làimh, 's air a lethchois, agus ar leis nach fhaca e taigh riamh roimhe ann.

DJM-N: Agus gu dè ach a ghabh an Rìgh ceum sìos rathad glinne a bha ri taobh shìos dhe, agus chunnaic e brugh beag do thaigh ann an sin. Agus bha e cho eòlach air a' ghleann agus a bha e air a leth-làimh agus air a leth-chois agus ar leis nach fhaca e taigh riamh ann.

JLC: Agus ghabh e sìos cuairt gu ò bha glinn a bha an taobh shìos dhe agus gu dè a chunnaic e ach bothan beag ann an sin shìos air ùrlar a' ghlinne. Agus bha e smaoineachadh gu robh e cho eòlach air an àite 's a bha [e] air a leth-làimh is air a leth-chois agus chan fhaca e taigh riamh ann.

CIM: Agus ghabh Rìgh Ėireann sìos cuairt air leathad cnoic a bha e eòlach gu leòr air, agus gu dè a chunnaic e ach brugh beag de thaigh shios air ùrlar a' ghlinne. Agus ar leis gu robh e cho eòlach anns a' cheart àite 's a bha e air a leth làimh agus air a leth chois agus cha dug e an aire do thaigh riamh ann.
What [happened] but that the king took a walk down the glen road that was below him. He saw a wee mound of a house there. And he was as knowledgeable of the glen as he was of the back [lit. "one half"] of his hand and foot, and he was certain he had never seen a house there before.

And what [happened] but that the king took a walk down the glen road that was below him, and he saw a wee mound of a house there. And he was as knowledgeable of the glen as he was of the back [lit. "one half"] of his hand and foot, and he was certain he had never seen a house there ever before.

And what [happened] but that the King took a walk down the glen road that was below him, and he saw a wee mound of a house there. And he was as knowledgeable of the glen as he was of the back [lit. "one half"] of his hand and foot, and he was certain that he had never seen a house there.

And he took a walk down to, oh, there were glens that were below him, and what did he see but a wee hut there down on the floor of the glen. And he was thinking that he was as knowledgeable of the place as [he] was of the back [lit. "one half"] of his hand and feet and he had never seen a house there.

And the King of Ireland took a walk down the declivity of a hill that he was plenty knowledgeable about, and what did he see but a wee mound of a house there down on the floor of the glen. And he was certain that he was so knowledgeable in ["of"] that very place as he was of the back [lit. "one half"] of his hand and foot and he had never noticed a house there before.

Table 10: Feature list for the end of Conall Gulban

\begin{tabular}{|c|c|c|c|c|c|}
\hline Features & Craig & DJM-D & DJM-N & CIM & JLC \\
\hline $\begin{array}{l}\text { gu dè ach a ghabh an Righ ceum sios } \\
\text { rathad glinne }\end{array}$ & $\checkmark$ & $\checkmark$ & $\sqrt{ }$ & cuairt & cuairt \\
\hline $\operatorname{glinn}(e)$ & $\checkmark$ & $\checkmark$ & $\checkmark$ & $\checkmark$ & leathad cnoic \\
\hline gu dè a chunnaice e & & & & $\checkmark$ & $\checkmark$ \\
\hline brugh beag (de thaigh) & $\checkmark$ & $\checkmark$ & $\checkmark$ & bothan & $\checkmark$ \\
\hline ùrlar a'ghlinne & & & & $\checkmark$ & $\checkmark$ \\
\hline ar leis nach fhaca e taigh & $\checkmark$ & $\checkmark$ & $\checkmark$ & & \\
\hline agus bha e cho è̀lach air a'ghleann & $\checkmark$ & $\checkmark$ & $\checkmark$ & & \\
\hline
\end{tabular}

In this section - the third paragraph of the story in Craig - the previously noticed patterns re-occur. The first clause is all but identical in Craig, DJM-D, and DJM-N, using the emphatic, 
clefted opening gu dè ach a ghabh an Righ ceum sios ("what but that the King took a step [walk] down"). On the other hand, the other two texts have the more straightforward ghabh NP sios cuairt ("the NP took a walk down"). The word glinn(e) ("of a glen"/"glens") is used in the first four texts, but leathad cnoic ("a hill declivity") is used in CIM. JLC goes with Craig, DJM-D, and DJM-N in describing the house as a brugh beag ("wee mound"), but, furthermore, CIM and JLC both use the phrase urlar a' ghlinne ("floor of the glen"). This phrase presents information that does not occur in Craig, contrasting to the semantically empty augmentation that usually occurs in DJM-N and DJM-D. Finally, the last sentence in Craig is almost identical in DJM-D and DJM-N, but it reads slightly differently in the other two texts. Once again, although CIM and JLC sometimes join with DJM-N, DJM-D, and Craig in certain features, they display rich semantic and lexical divergences from them in other ways. Such divergence is the hallmark of independent texts.

\subsubsection{Eachdraidh Mhànuis}

The story of Eachdraidh Mhànuis ("The Adventures of Manus") was another extremely popular tale in earlier times, judging by the oral and manuscript evidence in Ireland and Scotland (Bruford 1966). The story was apparently not submitted by Donald John under Neil's name (see Table 1 above). As for the previous tale, only the beginning was analyzed, with the results that Craig ${ }^{43}$ and DJM-D once again show a solid and aberrant relation to one another:

Table 11: Dice coefficient results for the beginning of Eachdraidh Mhànuis

\begin{tabular}{|ccc|}
\hline File 1 & File 2 & Relation \\
\hline Craig & DJM-D & 0.90 \\
JLC & CIM & 0.66 \\
Craig & JLC & 0.64 \\
Craig & CIM & 0.62 \\
DJM-D & JLC & 0.61 \\
DJM-D & CIM & 0.59 \\
\hline
\end{tabular}

The data here is consistent with that from the previous analyses: Craig and DJM-D show a relation value that is considerably higher (by a margin of 0.24 ) than the next highest value (that between JLC and CIM), thus providing further evidence of a derivative relationship between Donald John MacDonald's texts and those of Craig. Some examples follow: ${ }^{44}$

${ }^{43}$ Within $§ 3.2 .3$ “Craig” is used to refer to MacDhòmhnaill and Craig 1950:1-16.

44 The examples that follow are taken from the fourth sentence of MacDhòmhnaill and Craig 1950:1 and from its parallels within the other sources. 
Craig: Thàinig an seo bochdainn air Rìgh Lochlann, agus dh'eug e agus ghabh dà stàta dheug uallach na rìghachd gan ionnsaigh fhèin gus an tigeadh an toighre gu ìre a gabhail. (30 words)

DJM-D: Thàinig an seo bochdainn air Rìgh Lochlann, agus bhàsaich $\mathrm{e}$, agus ghabh dà stàta dheug uallach na rìghachd gan ionnsaigh fhèin, gus an tigeadh an toighre gu ìre a gabhail. (30 words)

CIM: Agus dh' fhàs an seo Rìgh Lochlann bochd agus bha e ùine mhòr air leabaidh agus a dh' aindeoin agus na b' urrainn lighichean a dhèanamh ris dh' eug e air a' cheann mu dheireadh. Agus cha robh an t-oighre ach fuathasach òg ach 's e a' rud a chaidh a dhèanamh chaidh an dà stàta dheug bu luaithe teist ann a Lochlann maideachadh orra airson bòidean na Rìoghachd a ghabhail gan ionnsaigh fhèin gus an tigeadh an t-oighre gu ìre an gabhail. (83 words)

JLC: . . agus dh'fhàs an seo Rìgh Lochlann bochd. Chaidh e gu laighe leapa agus a dh' aindeoin innleachdan is ionnsachadh dhotairean, bha a h-uile coltas air nach biodh e fada beò agus 's e a thachair gun do dh' eug Righ Lochlann. Agus cha robh dad an uair sin ach an dà stàta dheug bu luaithe [?] ann an Lochlann fhaighinn agus gun gabhadh iad bòidean na rìoghachd gan ionnsaigh fhèin gus an tigeadh an toighre gu ìre a gabhail. (80 words)
There now came an illness on the King of Norway, and he died, and twelve statesmen took control of the kingdom for themselves until the heir would be at the point to assume it.

There now came an illness on the King of Norway, and he died, and twelve statesmen took control of the kingdom for themselves until the heir would be at the point to assume it.

And the King of Norway now grew ill and he was a long time on his bed, and despite all that the doctors could do for him he died in the end. And the heir was only very young, and the thing that was done was that the twelve most reputable statesmen resolved to take oaths to take the kingdom for themselves until the heir would be at the point to assume it.

... and the King of Norway now grew ill. He went to lie on his bed and despite the efforts and learning of doctors, there was every indication that he would not be alive long, and what happened is that the King of Norway passed away. And there was nothing to do then but to find the most reputable statesmen in Norway so that they would take oaths to take the kingdom for themselves until the heir would be at the point to assume it.

It is interesting to note that CIM and JLC are much longer and descriptive than the passage in Craig and DJM-D; there is a difference of roughly 50 words between the former and latter pairs. The only difference between Craig and DJM-D here is the use of the word bhàsaich in DJM-D instead of dh'eug in Craig. This is a case of synonymic replacement, as described in \$3.1.4.1 above: both mean "died." In both CIM and JLC, the sickness leading up to the death is described in some detail, with physicians being brought in, but to no avail. The last several clauses in CIM and JLC are again similar, and overall these texts provide greater detail, departing from the more clipped account in Craig and DJM-D.

The quantitative results and textual analysis for Eachdraidh Mhànuis further bolster the position that Donald John's texts of the above tales are dependent upon those in Sgialachdan Dhunnchaidh. The next section will provide evidence that Donald John also utilized another source that one would not imagine to have been so readily available to a house in the Outer Hebrides in the 1950s - the Irish folklore journal Béaloideas, where Craig published several of Duncan's other tales.

\subsubsection{Gruagach nan Sealg}

Gruagach nan Sealg ("The Lady of the Hunts") is a Fenian tale and therefore of a slightly different nature than the others considered so far. Stories about Fionn MacCumhaill and his tribe 
of hero-warriors have been part and parcel of both oral and literate Gaelic tradition for well over a thousand years (Ó hÓgáin 1988:4). To present a slightly different picture of this text, and to anticipate the analyses of the coming section (§3.3), a sample from the middle of the tale was used. Although the example chosen was of direct speech (comprising most of the story), it was monologic and descriptive in nature rather than dialogic. Dialogue has been shown previously to be more likely to fossilize and remain constant over repeated tellings (Bruford 1966:60, 1979:31; Dòmhnallach 1989:218 n. 31; Zall 1998:49-50, 2007-10:7). Each example corresponds to the middle of paragraph five in Craig's text (1947:248).

Table 12: Dice coefficient results for a middle section of Gruagach nan Sealg

\begin{tabular}{|ccc|}
\hline File 1 & File 2 & Relation \\
\hline Craig & DJM-D & 0.91 \\
DJM-D & DJM-N & 0.90 \\
Craig & DJM-N & 0.90 \\
DJM-D & CIM & 0.56 \\
CIM & DJM-N & 0.56 \\
Craig & CIM & 0.55 \\
\hline
\end{tabular}

For this tale there were only four texts available for comparison, as John Lorne Campbell apparently did not record it from Duncan, or if he did, I am unable to find a record of it. However, it is evident that the same pattern is found here as in the previous results: Craig, DJM$\mathrm{D}$, and DJM-N co-occur in their lexicon but are substantially divergent from the other versions collected around the same time. Additionally, Donald John's text of Neil is once again more similar to Craig than to texts collected from Duncan by other ethnologists, in this case CIM. Some examples follow as an illustration of the textual relationships:

Craig: Chì thu an uair sin coltas froise a' cruinneachadh anns an àird an iar thuath, agus nuair a shileas i, cumaidh tu t-aghaidh innte, agus cha toir thu snaoidheadh a null no a nall air do cheann ach a' coimhead dìreach air meadhan na froise gus an tèid $i$ seachad, agus ann an deireadh na froise chì thu boireannach a' tighinn agus fàlairidh agus seud agus seabhag aice. Foighneachdaidh i dhiot c' àit a bheil [am] fear [a] thug glaodh air an fhìdeig. . . .

DJM-D: Chì thu an uair sin coltas froise a' cruinneachadh anns an àird an iar-thuath, agus nuair a shileas i cumaidh tu t-aghaidh innte, agus cha toir thu snaoidheadh a null no nall air do cheann ach a' coimhead dìreach ann am meadhain na froise gus an tèid $\mathrm{i}$ seachad agus ann an deireadh na froise chì thu boireannach a' tighinn agus fàlairidh agus seud agus seabhag aice. Foighneachdaidh i dhiot c' àit am bheil am fear a thug glaodh air an fhìdeag. ... .
You will see then the appearance of a shower forming in the high northwest, and when it pours, keep your face in her, and don't turn your head back or forth but keep looking straight ahead on ["at"] the middle of the shower until it goes past, and then at the end of the shower you will see a woman coming, with a palfrey and a jewel and a hawk. She will ask you where is [the] one who made a call on the whistle. . . .

You will see then the appearance of a shower forming in the high northwest, and when it pours, keep your face in her, and don't turn your head back or forth but keep looking straight ahead in the middle of the shower until it goes past, and then at the end of the shower you will see a woman coming, with a palfrey and a jewel and a hawk. She will ask you where is the one who made a call on the whistle. ... 
DJM-N: Chì thu an uair sin coltas froise a' cruinneachadh anns an aìrde an iar thuath, agus nuair a shileas i, cumaidh tu t' aghaidh innte, agus cha toir thu snaoidheadh a null no nall air do cheann ach a' coimhead dìreach ann am meadhain na froise gus an tèid $\mathrm{i}$ seachad, agus ann an deireadh na froise chì thu boireannach a' tighinn agus fàlairidh agus seud agus seabhag aice. Foighneachdaidh i dhiot càit am bheil am fear a thug glaodh air an fhideig. . . .

CIM: . . . chì thu cruinneachadh meall ann an sin agus thig am meall na chlachan-meallain san iar-thuath ann ad aghaidh agus air na chunna tu riamh na tionndaidh t' aghaidh-sa null na a-nall ach ag amharc direach ann an cridhe a' mhill agus ann an deireadh na froise thig marcraiche fàlairidh guirme agus e le sèin agus seabhag air foidhneachdaidh e dhiotsa cò sheinn an fhìdeag. . . .
Same as DJM-D above.

... you will see the forming of a shower there and the shower will arrive as hailstones in the northwest in your face, and for all you've ever seen [that is, for the love of your life] do not turn your head back or forth but keep gazing straight in the heart of the shower, and in the end of the shower a rider of a blue palfrey will come with an amulet and a hawk on him and he will ask you who sounded the whistle....

The first three examples are almost identical. The only differences to be seen are that while Craig has air meadhan na froise ("on the middle of the shower"), both DJM-D and DJM-N have ann am meadhan na froise ("in the middle ..."), and that the word fear ("man") is definite in both of DJM's texts, while it is (perhaps less idiomatically, or probably as a mistake) indefinite in Craig's. On the other hand, there are some significant differences between these three texts and CIM:

- Meall ("shower") is used in the place of its synonym fras (genitive singular froise).

- Cridhe a' mhill ("heart of the shower") is used in CIM in the place of meadhan na froise ("middle of the shower").

- Hailstones (clachan-meallain) are mentioned.

- Aird ("high") is not present as a modifier of iar-thuath ("northwest") in CIM.

- The phrase air na chunna tu riamh ("for the love of your life" [lit. "for all you have ever seen"]) is employed as an intensifier in CIM.

- The wording of the penultimate clause is significantly different, and sein (or the alternate spelling seun, "amulet") is used in CIM as opposed to seud ("jewel"). ${ }^{45}$

- CIM adds the detail that the palfrey is "blue," which is extra information and unlike the empty augmentation common to DJM-N and DJM-D.

- In the last clause, the rider of the palfrey is a woman in Craig and DJM's texts, but a man in CIM's.

Overall, given that CIM's text was taken down in 1949, two years after Craig's was published, one would expect it to be more lexically similar to Craig than are the other two, which were taken down in 1953 and 1954, yet this is not the case. It appears that the texts in Sgialachdan Dhunnchaidh are not the only ones on which Donald John's are dependent: he must

${ }^{45}$ This could have been a misapprehension in one of the transcriptions, although the words are semantically close enough to be interchangeable in the context of a traditional narrative. 
have also had access to this particular issue of Béaloideas ${ }^{46}$ or at least an offprint of it. Donald John submitted Duncan's version of Gruagach nan Sealg within the first 10\% of his work for the School of Scottish Studies, indicating that he had begun to use printed sources quite early on in his collection.

\subsection{Comparison of Donald John MacDonald's Manuscripts with More West Highland Tales}

From the examples above we know that Donald John submitted nearly identical texts on multiple occasions; clearly, those dealt with above that are attributed to Duncan and Neil ultimately derive from Craig. He utilized at least two of Craig's publications in the stories that he contributed, and it is reasonable to inquire to what extent he employed other printed sources. At least two of the tales that he wrote for the School, one under the name of Neil and the other under both Neil and Duncan's names, had been previously published in More West Highland Tales (J. F. Campbell 1940): Iain Òg Mac Righ na Frainge ("Young Iain Son of the King of France") and An Dà Sgiobair ("The Two Skippers"), which he submitted as Am Fear a Thug Cait dhan Tuirc ("The Man Who Took Cats to Turkey"). In the case of the first tale, Donald John submitted a form of it at least three times: under Neil's name, under Duncan's name, and as a copy from "an old manuscript" (see Table 1 above for the dates on which he took these down). In the case of the latter tale - a version of ATU 1561/506 - he took it down twice: once under Neil's name, and once from Mary Ann MacInnes (in 1957), a version that does not seem to be related to the other two. Interestingly, neither John Lorne Campbell nor Calum Maclean collected these stories from Duncan, at least in the form that Donald John offered them, which raises the question of whether or not they were in their repertoire in the first place, and if not — or, perhaps, even if they were - whether Donald John utilized a printed source when he wrote them down.

\subsubsection{Iain Òg Mac Rìgh na Frainge}

Iain $\dot{O} g$ is one of the long, meandering hero tales that were popular with Gaelic speakers up until the beginning of the twentieth century. To my knowledge, apart from Donald John's manuscripts it only appears in one place: More West Highland Tales (J. F. Campbell 1940). Campbell has this to say about it: "One of the regular Highland stories which have nothing earthly to do with books of any kinds that I ever read-quite peculiar" (275). A casual look at the versions submitted by Donald John reveals that they have a number of similarities with the one in MWHT in terms of wording and motif structure, but that these are less transparent than in the cases above. The following analyses were conducted to determine a possible relationship between Donald John's versions and the text published in MWHT.

One of the central tenets of the study of human memory is termed the serial position effect (see Ebbinghaus 1913; Robinson and Brown 1926). Essentially, items in a series of data are recalled in varying degrees depending on their location within that series. Research has generally confirmed that items occurring near the beginning or end of a series are recalled best,

46 Donald John submitted another tale — of the Märchen variety-that had previously appeared in a different issue of Béaloideas (Craig 1949): Am Fear a Thug am Boireannach às an Tuirc (see Table 1). It appears to be independent from Craig; see Lamb forthcoming. 
while those in the middle present difficulties for us. The primacy effect is the name given to the enhanced recall for items at the beginning of a series, and the recency effect refers to the relatively easier recall of terminal data. The primacy effect is explained by the fact that items at the beginning of a series are more available for repetition and practice. On the other hand, the recency effect occurs because items at the end of a data series are the last ones processed by working memory; it is assumed that they pass into long-term memory more readily due to the brain's relatively less fettered state at that time. ${ }^{47}$

If the versions of this tale as taken down by Donald John MacDonald and attributed to Neil and Duncan show a high level of correlation with $M W H T$, and a marked difference in their relation values for samples taken at the beginning, middle, and end, then it will help to distinguish between various competing hypotheses. First, if the relation values are reasonably high and it seems that there is a connection between Neil's and Duncan's versions and MWHT, we can assume that they either learned the tales from the book, had a strong connection through oral tradition to the person who originally narrated it, ${ }^{48}$ or that Donald John consulted the published source. If the relation values are V-shaped across the different sections, showing a dip in the middle section, then this result is the one we would expect if the tales had been learned in either of the first two ways, due to serial position effects. If, on the other hand, the relation values peak in the middle section, giving us an "inverted V" pattern, this finding would be consistent with Donald John having consulted $M W H T$ when he wrote down his versions. If a copyist were trying to avoid detection, it is likely that he or she would be more attentive to the beginning and end of a piece than to the middle section, which would be less noticeable to potential scrutinizers.

The following tables provide the relation values, separated into beginning, middle, and end sections.

Table 13: Dice coefficient results for the beginning of Iain Òg Mac Righ na Frainge

\begin{tabular}{|ccc|}
\hline File 1 & File 2 & Relation \\
\hline DJM-D & DJM-N & 0.65 \\
$M W H T$ & DJM-N & 0.65 \\
DJM-D & Manuscript & 0.56 \\
DJM-D & $M W H T$ & 0.55 \\
Manuscript & DJM-N & 0.51 \\
Manuscript & $M W H T$ & 0.43 \\
\hline
\end{tabular}
psychology.

${ }^{47}$ See Rubin 1995 for coverage of the mnemonic aspects of oral traditions from the perspective of cognitive

48 That is, Roderick MacNeill from Glen, Barra, circa 1860; again, the time and distance involved make this scenario unlikely as well. 
Table 14: Dice coefficient results for the middle section of Iain Òg Mac Righ na Frainge

\begin{tabular}{|ccc|}
\hline File 1 & File 2 & Relation \\
DJM-D & DJM-N & 0.76 \\
DJM-D & $M W H T$ & 0.75 \\
$M W H T$ & DJM-N & 0.72 \\
Manuscript & DJM-N & 0.69 \\
DJM-D & Manuscript & 0.68 \\
Manuscript & $M W H T$ & 0.67 \\
\hline
\end{tabular}

Table 15: Dice coefficient results for the end of Iain Òg Mac Righ na Frainge

\begin{tabular}{|ccc|}
\hline File 1 & File 2 & Relation \\
\hline DJM-D & DJM-N & 0.74 \\
DJM-D & $M W H T$ & 0.63 \\
$M W H T$ & DJM-N & 0.62 \\
DJM-D & Manuscript & 0.48 \\
Manuscript & DJM-N & 0.44 \\
Manuscript & $M W H T$ & 0.43 \\
\hline
\end{tabular}

Compared to the earlier results, these tales show a less clearly defined link between the hypothesized printed source and Donald John's texts. However, we have a basis of comparison to help disambiguate these results: the relation values previously obtained between Maclean, JLC, and Craig, which are fairly certain to be independent from one another. These values are as follows:

Table 16: Dice coefficient values between Maclean and Craig

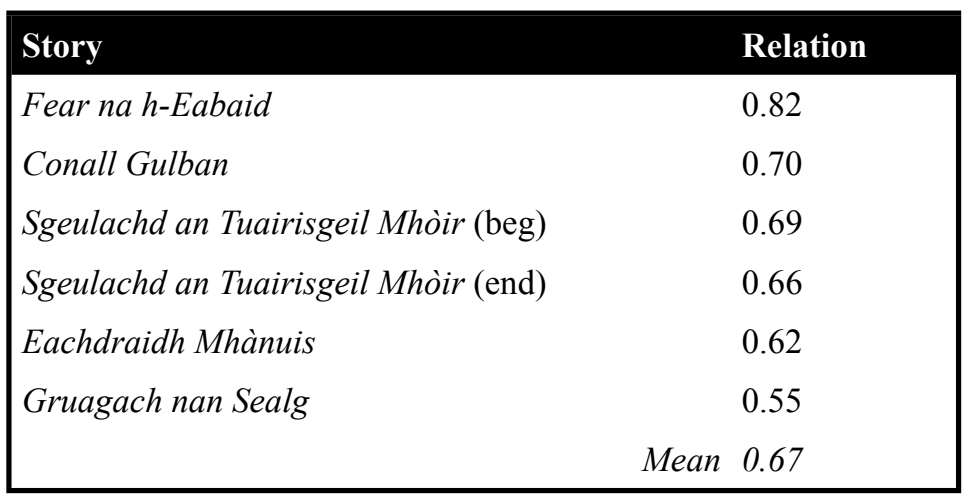


Table 17: Dice coefficient values between JLC and Craig

\begin{tabular}{|c|c|}
\hline Story & Relation \\
\hline Fear na h-Eabaid & 0.81 \\
\hline Sgeulachd an Tuairisgeil Mhòir (beg) & 0.72 \\
\hline Sgeulachd an Tuairisgeil Mhòir (end) & 0.69 \\
\hline Conall Gulban & 0.67 \\
\hline Eachdraidh Mhànuis & 0.64 \\
\hline Gruagach nan Sealg & N/A \\
\hline Mean & 0.71 \\
\hline
\end{tabular}

Table 18: Dice coefficient values between JLC and Maclean

\begin{tabular}{|c|c|}
\hline Story & Relation \\
\hline Fear na h-Eabaid & 0.79 \\
\hline Sgeulachd an Tuairisgeil Mhòir (end) & 0.69 \\
\hline Conall Gulban & 0.69 \\
\hline Sgeulachd an Tuairisgeil Mhòir (beg) & 0.68 \\
\hline Eachdraidh Mhànuis & 0.66 \\
\hline Mean & 0.70 \\
\hline
\end{tabular}

The mean relation values obtained at the bottom of the tables indicate the general amount of crossover that we might expect from Duncan MacDonald among his different versions of a single tale. Thus, we would anticipate, from tale to tale, that a relation value in the region of 0.70 would obtain. So far, we have no reason to expect that Neil's tales, as given by Donald John MacDonald, are independent from the tales of Duncan in Craig's publications. One might as well substitute the name "Neil" with "Duncan" in every case up until now. What do we make of the Iain O $g$ data? First, the relation values in the middle section are higher than either the beginning or the end, which gives us reason to think that neither Duncan nor Neil memorized the story from $M W H T$. The relation value of 0.75 in the middle section for DJM-D and MWHT is higher than what we would expect, given that the narrators are different people, from a different island, and that there is a span of nearly one hundred years between the versions. If our assumptions are correct about Donald John being less concerned with the middle section having a clear resemblance to the printed source, then our data is consistent with this scenario. The following graph illustrates the relation values between the three sources (DJM-D, DJM-N, and "manuscript") and the story as presented in $M W H T$, over the three different sections:

Graph 1: Dice coefficient values with $M W H T$ over three sections of Iain $\dot{O} g$ Mac Righ na Frainge from the manuscripts of Donald John MacDonald

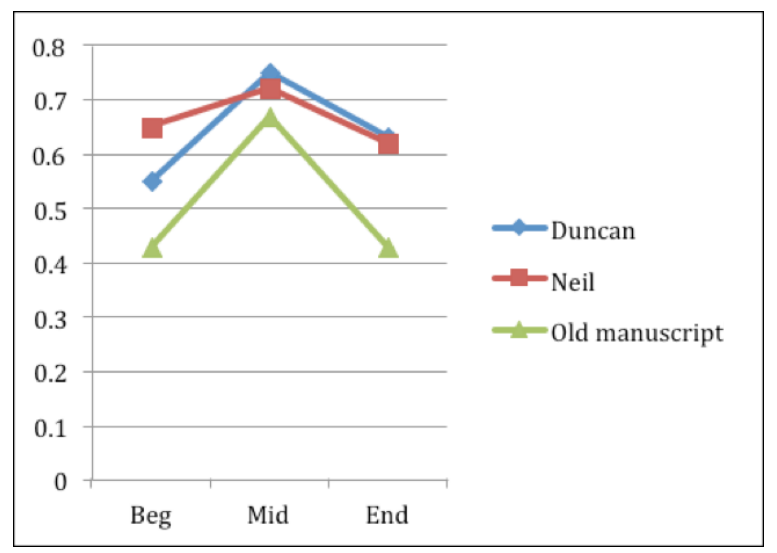


As is clearly visible, each version's relation value peaks in the middle, whereas the beginning and end sections are relatively similar, forming an inverted "V." Some examples from the beginning and middle section will be useful for gauging the level of semblance:

\section{Beginning section of Iain Òg Mac Righ na Frainge}

\section{MWHT}

Bha Rìgh anns an Fhraing agus phòs e, agus bha gaol mòr aige air a' Bhan Rìghinn, agus bha iad a' cur ann am mòr thoilinntinn le chèile.

Dh'fhàs a' Bhan Rìghinn trom, agus aig ceann a hùine, rug i leanabh mic. Bhaist iad an leanabh, agus is e Iain Òg, Mac Righ na Frainge, a thug iad air a' ghille.

Thug $i$ cìoch is glùn an seo dha gus an robh e bliadhna a dh' aois.

An ceann bliadhna, dh'fhàs i fhìn, tinn, bochd. An ùine ghoirid, fhuair $\mathrm{i}$ bàs,

agus bha an Rìgh fo leann-dubh is fo mhulad mòr, a' caoidh na Ban Rìghinn. ...

\section{MacD-D}

Chuala mise siud a bha ann Rìgh na Frainge, agus mar a bha Rìgh na Frainge ann, phòs e, agus ann an ceann ùine rugadh mac dha. Agus 's e Iain a thugadh mar ainm air a ghille, agus 's e Iain òg Mac Righ na Frainge a chainte ris.

Thug a bhàn Rìghinn cìoch is glùin dhan leanabh fad bliadhna, agus nuair a bha ceann na bliadhna suas, dh'fhàs i tinn agus ann an ùine gu math goirid bhàsaich $i$, agus dh' fhàg i Iain agus an Rìgh leotha fhèin.

Bha an Rìgh fo mhulad mòr ag ionndrainn na bàn Rìghinn. . . .

\section{MacD-N}

Chuala mise siud a bha ann Rìgh na Frainge, agus mar a bha Rìgh na Frainge ann, phòs e, agus bha gaol mòr eadar e fhèin agus a bhàn-Rìgh, agus bha iad uamhasach toilichte còmhla.

Ann an ceann ùine an so, dh' fhàs a' bhan Rìgh trom, agus aig an àm rug $\mathrm{i}$ leanabh mic.

Chaidh a leanabh a bhaisteadh agus Iain a thoirt mar ainm air. Bha iad a dol air aghaidh glè mhath còmhla, an sin, iad fhèin agus an leanabh.

Thug a bhan Rìgh cìoch agus glùin dha fad bliadhna. Ach ann an ceann na bliadhna, dh' fhàs a' bhan Rìgh tinn, agus a dh' aindeoin gach luchd-sgil a thug an Rìgh ga h-ionnsaigh, cha do rinn e feum sam bith, agus ann an ùine ghoirid fhuair a bhan Rìgh am bàs.

Bha an Rìgh an uair-sin fo bhròn mòr ag ionndrainn na bàn-Rìgh. . . .

\section{Old Manuscript}

Ma tà, bha siud ann uaireigin Rìgh anns a Fhraing, agus bha aon mhac aige. Cha robh a mac ach na phàisde gu math òg nuair a bhàsaich a' bhan Rìghinn.

Bha an Rìgh a nis air fhàgail leis fhèin. ... 
There was a king in I heard there that there France and he married, was a king of France and and he had much love on the queen, and they were extremely happy together.

The queen grew pregnant, and after some time, she bore a baby boy. They baptized the boy, and it is Young Iain, the song of the King of France that they named the boy.

She gave breast and knee to him until he was one year old.

At the end of the year, she grew sickly, ill. In a short while she died, as there was a king of France, he married, and in a while a son was borne to him. And they named him Iain, and it was Iain son of the King of France that he was called.
The queen gave him breast and knee until he was one year old, and at the end of the year, she grew ill and in short time died and she left Iain and the King on their own.
I heard there that there was a king of France, and as there was a king of France, he married, and there was much love between him himself and the queen, and they were extremely happy together.

In a while, then, the queen grew pregnant, and in time, she bore a baby boy.

The boy was baptized and they called him Iain. They were getting on very well together, then, themselves and the baby.
The queen gave breast and knee to him for a year. But after the year, the queen grew sickly, and despite every skilled person that the king brought to her, it didn't do any good, and in a short while she died.
Then, that was there once upon a time a king in France, and he had one son. His son was only a baby when the queen died.

The king was then left by himself. ... and the king was under a misery and great sadness, grieving over the queen....
The king was under great sadness grieving over the queen. ...
The king was then under great sadness grieving over the queen. ...

These passages could easily be from four different narrators, despite sharing certain phrases, such as cioch is glùin ("breast and knee" [MWHT, MacD-D, MacD-N]) and fo mhulad mòr ("under great sadness" [MWHT, MacD-D]). However, although the versions are different on the surface, it is still possible that they could be derivative; there is very little in the non-MWHT versions that could not have been semantically extrapolated from it. Looking at the middle section, which had the highest relation score, this position becomes more tenable: ${ }^{49}$

\footnotetext{
49 The paragraph breaks in the right three texts are altered to facilitate comparison; $M W H T$ is as per the original in this sense, beginning on page 258 of J. F. Campbell 1994. All punctuation is presented as it appears in each individual text.
} 
MWHT

Thug iad a nuas an tsail. Chuir esan a cheann ann an eig, is chuir iadsan an cinn ann an eagannan mu a choinneamh, agus spion e na cinn às na $h-$ amhaichean aig a h-uile gin aca, is thug e fhèin a cheann às sàbhailte. Cha robh an seo gin aca beò ach am bodach.
MacD-D

Thug iad a nuas an tsail. Chuir Iain a cheann ann an eig agus chuir iadsan an cinn anns na h-eagan mu choinneamh, agus spìon esan na cinn às na $h$ amhaichean aig a h-uile fear aca, agus thug e fhèin a cheann às sàbhailte. Cha robh a nis gin aca beò ach am bodach.

Rug e an sin air a' Bhodach, is chuir e glùn air an amhaich aige. Thuirt e ris, 'Tha am bàs os do chionn : gu dè t-èirig ?'

'Ma tà, is mòr sin,' arsa am Bodach; 'is iomadh èirig duine bhochd agus duine beairtich a tha fon fhàrdaich $\mathrm{a}$ tha $\mathrm{an}$ so.'

'Tha sin agamsa, agus am bàs os do chionn-sa; ge dè t-èirig?'.

'Och ! chan eil tuilleadh èirig agam, ach innsidh mi dhuibh mar a bheir sibh beò sia comhdhaltan deug Rìgh Èireann, ma leigeas sibh leam mo bheatha.'

'Dè mar a bheir sinn beò iad ?' arsa Iain
Rug Iain an uair sin air a' bhodach, agus chuir e a ghlùin air a sgòrnan aige. "Am bàs os do chionn", arsa esan, "gu dè t-èirig".

"An dà", arsa am bodach, "'s mòr sin. 'S iomadh èirig duine bhochd is bheairteach a tha anns an fhàrdaich a tha seo".

"Bidh sin agam agus do cheann", arsa Iain, "gu dè t-èirig".

"Ò, chan eil an còrr èirig agam", arsa am bodach, "ach innseadh [sic] mi dhuibh mar a bheir sibh beò sia comhdhalta deug Rìgh Èireann mu leigeas sibh mo bheatha leam",

"Dè mar a bheir sinn beò iad", arsa Iain.

\section{MacD-N}

Dh' fhalbh iad agus thàinig fear aca leis an t-sail. Chuir esan a cheann anns an eag, agus chuir iadsan an cinn anns na h-eagannan mu-choinneamh, agus spìon e na cinn às na $h$ amhaichean às a h-uile gin aca, agus thug e fhèin a cheann às sàbhailte. Cha robh an uair sin beò ach am bodach.

Rug e an uair sin air a' bhodach, agus chuir e ghlùin air an amhaich aige. "Am bàs os do chionn", arsa esan ris a bhodach, "gu dè tèirig".

"An dà 's mòr sin", arsa am bodach. "'S iomadh èirig duine bhochd agus bheairtich a tha fon fhàrdaich so".

"Tha sin agam agus do bhàs", arsa Iain, "gu dè t-èirig".

"Ò chan eil tuilleadh èirig agam", arsa am bodach, "ach innse [sic] mi dhut ciamar a bheir thu beò sia comhdhalta deug Rìgh Èireann mu leigeas tu mo bheò leam".

"Agus", arsa Iain, "gu dè mar a bheir sinn beò iad".

\section{Old Manuscript}

Thug iad a nuas an tsail dharaich, agus dh' iarr Iain oirre-san an cinn a chuir anns na h' eagan. Chuir e fhèin a cheann anns an eag mun coinneamh. Spìon e an uair sin na cinn às a h-uile gin aca, agus thug e fhèin a cheann às sàbhailte.

Cha robh gin dhiubh air fhàgail an uair sin ach am bodach.

Ghabh e chun a bhodach, agus leig e air an ùrlar e. "Am bàs os do chionn", arsa esan, "gu de t-èirig".

"An dà 's mòr sin", arsa am bodach, "'S iomadh èirig duine bhochd agus bheairteach a tha fon fhàrdaich a tha seo".

"Bidh sin agam sa agus do bhàs", arsa Iain. ["Gu dè t-èirig".]

"Ò chan eil an còrr èirig agam-sa" arsa am bodach, "ach innsidh mi dhut mar a bheir thu beò sia comhdhaltan deug Rìgh Ėireann".

"Dè mar a bheir sinn beò iad", arsa Iain. 
They brought forth the beam. He put his head in a notch, and they put their heads into the notches opposite, and he pulled the heads out of every one of their necks, and he himself took his head out safely. There was now none amongst them living apart from the old man.

He then grabbed the old man, and he put his knee on his neck. He said to him, "The death is above you: what is your ransom?"

"Well then, it is large," said the old man, "many is the ransom of a poor man and a rich man that is beneath this roof."

"That is mine, and your
death is above you;
what is your ransom?"
"Och, I have no further
ransom, but I will tell
you how you can
resuscitate sixteen of
the King of Ireland's
foster-brothers, if you
allow me to keep my
life."

"How may we bring them alive?" said Iain.
They brought forth the beam. Iain put his head in a notch and they put their heads in the notches opposite, and he pulled the heads out of the necks of every one of them, and he himself took his head out safely. There was then none amongst them living apart from the old man.

Iain then grabbed the old man, and he put his knee on his throat. "The death above you," he said, "what is your ransom?"

"Well," said the old man, "it is large. Many is the ransom of a poor man and a rich man beneath this roof [slight difference in wording here]."

"That will be mine and your head," said Iain, "what is your ransom?"

"Oh, I have no further ransom," said the old man, "but I will tell you how you can resuscitate sixteen of the King of Ireland's foster brothers, if you allow me to keep my life with me."

"How may we bring them alive?" said Iain.
They went and one of them came with the beam. He put his head in a notch, and they put their heads in the notches opposite, and he pulled the heads out of the necks of every one of them, and he himself took his head out safely. There was at that time none alive apart from the old man.

He then grabbed the old man, and he put his knee on his neck. "The death above you," he said to the old man, "what is your ransom?"

"Well it is large then," said the old man. "Many is the ransom of a poor man and a rich man that is beneath this roof."

"That is mine and your death," said Iain, "what is your ransom?"

"Oh, I haven't any other ransom," said the old man, "but I'll tell you how you can resuscitate sixteen of the King of Ireland's foster-brothers, if you allow me to have my life."

"And," said Iain, "how may we bring them alive?"
They brought forth the oak beam and Iain asked them to put their heads in the gaps. He put his own head in the gap opposite them. The then pulled the heads out of every one of them, and he took his own head out safely. There was not any of them alive then apart from the old man.

He took to the old man, and he felled him to the floor. "The death above you," he said, "what is your ransom?"

"Well, it is large," said the old man, "many is the ransom of a poor man and a rich man beneath this roof."

"That will be mine and your death," said Iain.

"Oh I haven't any further ransom," said the old man, "but I will tell you how you can resuscitate sixteen foster-brothers of the King of Ireland."

"How may we bring them alive?" said Iain.

In practical terms these four excerpts are all but identical. There are slight differences, such as in tense (bidh sin agam ["that will be mine"] versus tha sin agam ["that is mine"]), close synonyms (for example, an corr versus tuilleadh ["any more"]), placement of the narrative verb (arsa ["said"]), and the varying use of emphatic suffixes. However, there is strikingly little that is different, and these features were discussed in $\S 3.1 .4$ as being among the possible consequences of textual modification. Is it possible that four independent sources of a tale would have sections in them that progress in a virtually identical, word-for-word fashion? 
Carol Zall discusses what she terms "Type 3" language: "dialogue and other phrasing which does not seem to be identifiably archaic, rhythmic, or otherwise 'special,' but which nevertheless recurs from story to story in a highly similar form" (2007-10:7). By this definition, the above excerpt would fit. But interestingly, the examples that she provides of Type 3 language - from Gaelic storyteller Brian Stewart ${ }^{50}$ _ do not exhibit the same unity of word and phrase that we see in the middle section of Iain $\dot{O} g$. The examples that she provides in another article (Zall 2006-07) are closer, but they are still not as close as the ones above. Although the results for Iain $\grave{O} g$ are suggestive rather than conclusive, they fit in with the trends discussed elsewhere in this paper.

\subsection{An Dà Sgiobair/Am Fear a Thug Cait dhan Tuirc}

As a final analysis, I investigated whether or not the same "inverted V" pattern held with another tale from MacDonald's collection, An Dà Sgiobair/Am Fear a Thug Cait dhan Tuirc ("The Two Skippers"/“The Man Who Took Cats to Turkey"). This tale was collected around 1860 by one of J. F. Campbell's collectors ${ }^{51}$ from Alexander MacNeill of Ken Tangval (Ceann Tangabhal), Barra. It is an international tale of the "Whittington's Cat" type (ATU 1651), but in this rendition it is conflated with ATU 506, "The Rescued Princess." Although the tale was not overly common in Uist, it was collected there at least four other times. ${ }^{52}$ Neither JLC nor CIM took it down from Duncan, raising the same questions as in the previous case. The following graph details the relation values between the versions from $M W H T$ and DJM's collection:

Graph 2: Dice coefficient values over three sections of ATU 1651/506 in DJM-N and MWHT

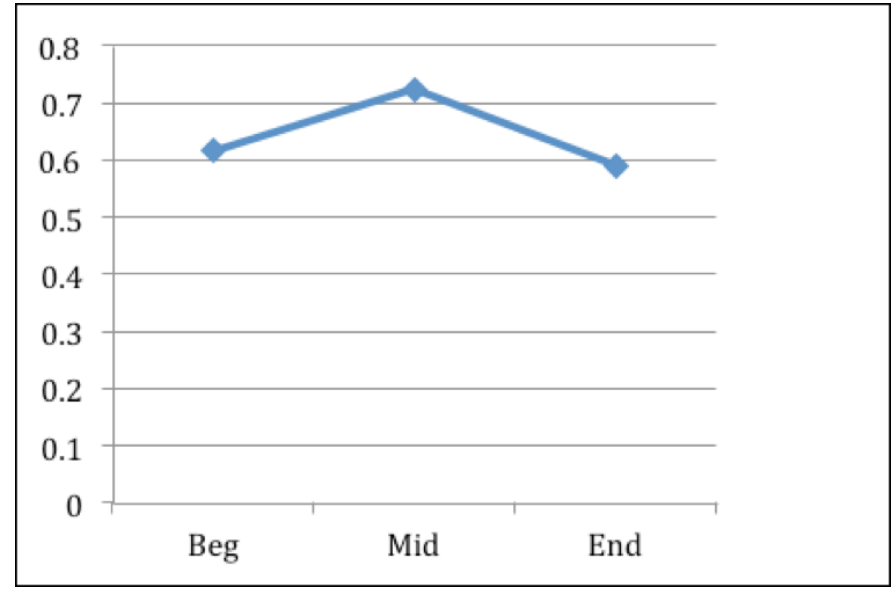

50 The nephew of the famous traveler-storyteller Ailidh Dall.

${ }^{51}$ In J. F. Campbell 1940 (390), it is noted that it was probably Hector MacLean.

52 According to the School of Scottish Studies Tale Archive, it was collected once in North Uist, twice in Benbecula, and another time in South Uist (in DJM's manuscripts, from a separate individual, noted as partial). 
Here, the same pattern emerges that was seen in the case of Iain Òg, suggesting that Donald John may have used tales from MWHT but actively transformed them, paying more attention to the beginning and end than the middle section.

The table below presents the relation values obtained from the analysis:

Table 19: Dice coefficient results from ATU1650/509

(DJM-N versus $M W H T$ )

\section{Beg}

Mid

End

0.62

0.73

0.60

For the same reasons of temporal and geographical remoteness as discussed above in $§ 3.3 .1$, a middle-section ${ }^{53}$ value of 0.73 is greater than what we would expect. Relatively long sequences of word-for-word text occur, and despite the differences, the same basic paragraph structure obtains, along with the possibility of synonymic replacement and augmentation. The following are some samples from this middle section:

\section{MWHT}

An uair a ràinig e taigh duine uasail, bha làmhan sgaoilte aice roimhe.
MacD-N

Nuair a ràinig esan, neoar-thaing nach robh basan sgaoilte roimhe ann an sin.

"Nis", arsa an nighean ris, "a-màireach, thèid mi fhìn agus m' athair a mach a ghabhail cuairt far am bi thu a' cur an luchd a mach às an t-soitheach".

Shuidh iad air na pocannan, agus cha b' fhada gus an tug am bodach fanear gur e òr a bha anns na pocannan.

"Ach athair", arsa an nighean, an ceann greis, "nach iarr sibh air an duine tha seo mise a phòsadh".

\section{MWHT (trans.)}

When he arrived at the gentleman's house, her hands were spread before him.

"On the morrow," she said, "My father and I will go and walk to where you will be putting out the load."

They sat on the sacks, and the old man noticed that they were full of gold.

"My father," said she, "won't you ask this man to marry me?"

\section{MacD-N (trans.)}

When he arrived, indeed, palms were spread before him there.

"Now," said she to him, "tomorrow, I myself and my father will go out and have a walk to where you will be putting the load out of the vessel."

They sat on the sacks, and it wasn't long until the old man noticed that it was gold that was in the sacks.

"But father," said the girl after a while, "won't you ask this man to marry me?"

\footnotetext{
53 The section is taken from J. F. Campbell 1940:388.
} 
'Cha phòsadh am fear ud nighean an rìgh is feàrr $\mathrm{a}$ bha riamh air an t-saoghal, agus na tha an seo de òr aige'
"Cha phòsadh am fear ud nighean an rìgh is fheàrr a bha riamh air an t-saoghal, agus na tha seo do dh' òr aige".
"Yon man wouldn't marry the daughter of the best king that ever was, even if he had all of this gold."
"Yon man wouldn't marry the daughter of the best king that ever was, even if he had all of this gold."

Where there are differences between these excerpts, they are slight. Any of the phrases in DJM-N here could have been derived from the text in $M W H T$; none add any substantive information, and the tendency is for them to evince slightly more unusual words, a feature that correlates with a text that has been copied from another source.

As mentioned above, in addition to using a more unusual vocabulary, copyists may resort to using a more marked morphosyntax, for similar reasons. Both of these traits can be seen in the differences between the first two examples above. In MacD-N, an emphatic suffix is added, and the slightly marked phrase neo-ar-thaing ("indeed"), an amplifier, is present. Additionally, basan ("palms") is used rather than the more pedestrian làmhan ("hands"), and there is a bit of deictic filler applied to the end: ann an sin ("there"). The same tendency is seen in the third paragraph, where thug am bodach fa-near ("the old man noticed") is present in MWHT but the fronted adverbial phrase cha b' fhada gus an tug am bodach fa-near ("it was not long until the old man noticed") is in MacD-N. Where MWHT has a pronoun, MacD-N often deploys full referents: ise ("her," emphatic) in the fourth paragraph versus an nighean ("the girl"). All of these differences could be seen as an avoidance of the original text.

As in the case of Iain $O g$, one wonders if this is Donald John, the storyteller apparent, modeling his language according to his knowledge of the traditional narrative register as acquired from his uncle and father. He was indubitably a gifted Gaelic speaker and writer, judging by his poetry (MacDhòmhnaill and Innes 1998), and it would have easily been within his capacities. However, the quantitative results are not without ambiguity, and we would be illadvised to discount entirely the possibility that these two stories are survivals from oral tradition, as unlikely as it seems in the present context. A more thorough analysis than is possible here would hopefully reveal further answers. If the evidence points towards the stories being authentic, it will raise an entirely new set of questions, with intriguing consequences for the study of human memory and the limits of retention from oral tradition.

\section{Conclusions}

The almost word-for-word correspondence between the tales of brothers Neil and Duncan MacDonald has been taken in the past as a given, based upon observations supplied by Bruford (1979) and others. It was viewed as a manifestation of the verbally conservative aesthetic inherent to this particular family, who are descendants of an important line of once, perhaps, professional storytellers. However, the present study has scrutinized the evidence for the assumption that the brothers' tales were identical and found it in all likelihood to be specious.

Neil and Duncan were believed to have had the same versions of their tales because they actually were the same versions: Donald John MacDonald copied the texts that he attributed to them from 
published collections of Duncan's stories (Craig 1947; MacDhòmhnaill and Craig 1950). The statistical results, the signs of visual copying, and their abnormally close lexical and phrasal correspondence make this the only plausible conclusion. Where a text of Duncan's was published by K. C. Craig and known to Donald John MacDonald, it was used in his manuscripts as the basis of the stories attributed to his father and uncle.

These results also give us grounds for questioning the authenticity of another two stories in the collection that may have ties to a separate published source, namely More West Highland Tales (J. F. Campbell 1940). Consequently, we are now left with a considerably more limited range of material from this important storytelling family than we previously thought. Where we believed we had four independent versions, we now have two, and where we thought we had three, we have one. In the case of Iain $O g$, we have reason for doubting the authenticity of both of the extant versions. There are thus significant implications for the study of variation in Gaelic traditional narrative, particularly regarding the oral versions of the literate Gaelic romances, for which there is already only scant and precious evidence.

In many ways, the present study - through demonstrating the degree of similarity between his independent versions of Fear na h-Eabaid by means of quantitative evidence-has confirmed the position that Duncan MacDonald was a conservative and consistent storyteller. On the other hand, in the case of Neil, since Donald John is the only source we have for his tales, he has become the proverbial "missing man." One prospect for future research would be to determine whether any of the texts attributed to Neil were actually taken down from him verbatim. It may be possible to make this determination through investigating the tales that he did not have in common with Duncan, particularly those that could not have been taken from a published source. Such an undertaking would need to borrow techniques from the area of forensic linguistics, and unfortunately it will perforce exclude any of the larger hero tales. Apart from An Ceatharnach Caol Riabhach, ${ }^{54}$ these tales all appear to have been taken from Craig's work, which leaves only the shorter anecdotes and historical narratives, but they may be sufficient for determining what Neil's storytelling style was like in a general sense.

This study is the first time that a statistical measure of lexical consistency has been applied to questions of variation and authorship in traditional Gaelic narrative, and I am not aware of any other language's "oral" tradition being investigated in this manner. Using similar techniques, it might be possible to begin to better understand the relationship between orally collected versions of the Gaelic romances and the ones in manuscript form. The oral-literate debate has plagued Gaelic scholarship for many years in the past with no real resolution (see, for example, Ó Coileáin 1977), and an extension of the approach here could potentially help to break down the barriers that have thwarted progress. More immediately, it would be a relatively simple matter to evaluate Bruford's claim (1979:35) that Duncan MacDonald made a distinction in his repertoire between the originally literate hero tales and the primarily oral Märchen, with the former being more consistent from recitation to recitation. If this claim could be confirmed, it would have interesting implications for the study of storytelling registers and raise the question

54 This tale is a curious case because it was not actually taken down from Duncan in any detail. He said that his father, from whom he heard it, had remembered only a fragment of it (which can be found with registration in the Calum Maclean corpus: http://www.calum-maclean.celtscot.ed.ac.uk/calmac). 
of whether or not a type of literate aesthetic could have come down in oral tradition bundled with these hero tales. ${ }^{55}$

It remains to be seen what connection there is between Donald John's manuscripts and More West Highland Tales, as well as other published sources. The approach taken here will be a useful aid for bringing this under-utilized collection into the light and disentangling its connections to oral and literate sources. In a broad sense, with the increasing number of valuable resources coming online in a digital format, ${ }^{56}$ the deployment of computational techniques to support investigations in Gaelic ethnology should be a fruitful modus operandi in the time to come.

Of course, the present findings raise a number of important and, to varying extents, charged lines of inquiry. It is almost impossible, for example, not to speculate on what might have motivated Donald John MacDonald to utilize these published sources in the way that he did. However, when pursuing such inquiries, it is important to be cognizant of the fact that both professional and lay ethnologists have adopted a range of collection practices throughout history. These practices have themselves been framed by a range of philosophies regarding best practices - when such conscious directives can even be said to have been evident in the first place - and, crucially, the best way for representing oral traditions. The work of past luminaries such as Alexander Carmichael, Marjory Kennedy-Fraser, and James Macpherson immediately comes to mind; scholars have both panned and praised their efforts ever since..$^{57}$

I would like to stress, in closing, that it is not the purpose of this essay to bring either Donald John MacDonald or his manuscript collection into disrepute. I have tried to steer away from value judgments and debates of the above nature, as they are beyond my present purpose. It is necessary to acknowledge the elephant in the room, but it will need to be dealt with elsewhere. To conclude on a positive note, my impression is that there is much within the manuscripts that is taken from first-hand sources, although it will require time to evaluate them properly in toto.

Like so many other linguistic cultures in the world, Gaelic speakers in the twentieth century gradually grew to spend more time immersed in mass-media-based entertainment than in sharing their traditional songs and stories. What makes Gaelic ethnology so compelling, particularly for those who were not raised within such a rich oral tradition, is that it represents a type of cultural inheritance that was once common to us all.

55 Since writing the initial version of this essay, I have had the opportunity to conduct an initial investigation into this matter (Lamb forthcoming) and can report that no statistically significant difference obtained between Duncan's Märchen and hero tales in terms of verbal consistency. Some of Bruford's (1979) conclusions can now be understood as artifacts of the underlying, and previously undiscovered, relationship between Craig's and DJM's texts.

56 To name three, Tobar an Dualchais/("Kist o Riches") (http://www.tobarandualchais.co.uk/), The Calum Maclean Project (http://www.calum-maclean.celtscot.ed.ac.uk/calmac), and more recently the Carmichael Watson Project http://www.carmichaelwatson.lib.ed.ac.uk).

57 The work of Alexander Carmichael has gained rejuvenated prominence since the launch of the website mentioned in the preceding note and through the seminal work being conducted by those associated with it. For surveys of some of the issues involved with assessing his collection, see Robertson 1976, J. L. Campbell 1978, and Patton 1988. 
With every storm surge, the sea around Uist has for millennia taken as its bounty what we would now consider treasures, removed from the dunes. ${ }^{58}$ The treasures of oral culture have no less value than their archaeological counterparts, but the storms are more subtle and are, some would say, even a necessary precursor to progress. Although a strong oral tradition persisted in Uist longer than in most other places in Europe, it is now not possible to collect Gaelic stories and songs in the way it was only sixty years ago. Because of this, Donald John MacDonald's collection is invaluable, even if a proportion of it is dependent upon other sources, and the time required to understand it will be well spent. We have him, and many others, to thank for giving at least some treasures shelter from the storm.

\section{Acknowledgements}

My sincere thanks to Dr. Michael Oakes for providing support on the side of plagiarism detection software and statistics, and to Mike Scott for assistance with WordSmith Tools. To my colleagues in Celtic and Scottish Studies, Drs. Margaret Mackay, Wilson McLeod, and John Shaw, for helpful comments and suggestions on drafts of this paper. I am also grateful to Dr. Mackay for locating pieces of correspondence that were invaluable for understanding the briefs given to early collectors of the School. Many thanks to Dr. Cathlin Macaulay, for helping to locate a picture (Image 1) of Duncan MacDonald from the photographic archive of the School of Scottish Studies. Finally, my thanks to Dr. John MacInnes for providing background information on the early days of the School.

The University of Edinburgh

\section{References}

Alzahrani et al. 2012

Anonymous 1957

Bauer et al. 2009

Bruford 1963-65
S. Alzahrani, N. Salim, and A. Abraham. "Understanding Plagiarism Linguistic Patterns, Textual Features and Detection Methods." IEEE Transactions on Systems, Man, and Cybernetics, Part C: Applications and Reviews, 42, ii: 133-49.

"Folk-tales from South Uist." Scottish Studies, 1:14.

Michael Bauer, Roibeard Ó Maolalaigh, and Rob Wherrett. Survey of Gaelic Corpus Technology. Glasgow: University of Glasgow.

Alan Bruford. "Eachtra Chonaill Gulban: An Irish Hero-Tale in Manuscript and Oral Tradition." Béaloideas, 31:1-50.

58 See the fine work being done by Shorewatch on documenting the archeological remains of coastal Scotland: http://shorewatch.co.uk/html/accessarch.html. 
Bruford 1966

Bruford 1968

Bruford 1979

Bruford 1981

Bruford 1986

Bruford 1996

Bruford and MacDonald 2003

J. F. Campbell 1940

J. F. Campbell 1994

J. L. Campbell 1978
"Gaelic Folk-Tales and Mediaeval Romances: A Study of the Early Modern Irish 'Romantic Tales' and Their Oral Derivatives." Béaloideas, 34:i-285.

__. "Murchadh mac Briain and an Díthreabhach.” Éigse, 12:301-26.

"Recitation or Re-creation? Examples from South Uist Storytelling." Scottish Studies, 22:27-44. "Memory, Performance, and Structure in Traditional Tales." Arv: Scandanavian Yearbook of Folklore, 34:103-09. “Oral and Literary Fenian Tales.” Béaloideas, 54/55:25-56. "The Hermit Disturbed and Undisturbed." In (Re)Oralisierung. Ed. by Hildegard L. C. Tristram. Script Oralia, 58. Tübingen: Narr. pp. 177-206.

Alan Bruford and Donald A. MacDonald. Scottish Traditional Tales. Edinburgh: Birlinn.

John F. Campbell. More West Highland Tales. 2 vols. Ed. by the Scottish Anthropological and Folklore Society. Edinburgh: Oliver and Boyd. More West Highland Tales. 2 vols. Ed. by John G. MacKay, William J. Watson, Donald Maclean, and H. J. Rose. Edinburgh: Birlinn.

John L. Campbell. "Notes on Hamish Robertson's 'Studies in Carmichael's Carmina Gadelica."” Scottish Gaelic Studies, 13:1-17.

J. L. Campbell and Thomson 1963 John L. Campbell and Derick S. Thomson. Edward Lhuyd in the Scottish Highlands, 1699-1700. Oxford: Clarendon.

Chafe 1982

Wallace Chafe. "Integration and Involvement in Speaking, Writing, and Oral Literature." In Spoken and Written Language: Exploring Orality and Literacy. Ed. by Deborah Tannen. Norwood: Ablex. pp. 35-53.

K. C. Craig. "Sgialachdan ó Uibhist.” Béaloideas, 17:231-50.

Craig 1949 "Sgialachdan Eile ó Uibhist: Am Fear a Thug am Boireannach às an Tuirc." Béaloideas, 19:134-51. 
Dòmhnallach 1989

Draak 1957

Dwelly 2001 [1911]

Ebbinghaus 1913

Halliday 1989

Hillers 2007

Honko 2000

Innes 2011

Jackson 1951

Lamb 2008

Lamb forthcoming

Lease 1919

MacDhòmhnaill 1974
Dòmhnall Eairdsidh Dòmhnallach. "Trì Ginealaichean de Sgeulachd." In Gaelic and Scotland/Alba agus a' Ghàidhlig. Ed by William Gillies. Edinburgh: Edinburgh University Press. pp. 185-221.

Maartje Draak. “Duncan MacDonald of South Uist.” Fabula, 1:47-58.

Edward Dwelly. Illustrated Gaelic-English Dictionary. New ed. Edinburgh: Birlinn.

H. Ebbinghaus. Memory: A Contribution to Experimental Psychology. Trans. by H. A. Ruger and C. E. Bussenius. New York: Teachers College, Columbia University.

M. A. K. Halliday. Spoken and Written Language. 2nd ed. Language Education. Oxford: Oxford University Press.

Barbara Hillers. "Storytelling and the International Folktale in Scotland." In Oral Literature and Performance Culture. Ed. by John Beech, Owen Hand, Fiona MacDonald, Mark A. Mulhern, and Jeremy Weston. Edinburgh: John Donald. pp. 159-70.

Lauri Honko. "Thick Corpus and Organic Variation: An Introduction." In Thick Corpus, Organic Variation, and Textuality in Oral Tradition. Ed. by Lauri Honko. Studia Fennica Folkloristica. Helsinki: Finnish Literature Society. pp. 3-26.

Bill Innes. Telephone conversation with the author. June. Edinburgh.

Kenneth Jackson. Unpubl. letter. to Neil MacNeill, Isle of Barra. Edinburgh: School of Scottish Studies Archive.

William Lamb. Scottish Gaelic Speech and Writing: Register Variation in an Endangered Language. Belfast: Cló Ollscoil na Banríona.

_ "Recitation or Re-creation? A Reconsideration: Verbal Consistency in the Gaelic Storytelling of Duncan MacDonald." In A Guid Hairst: Festschrift for Margaret A. Mackay. Ed. by Katherine Campbell, Neill Martin, Gary West, and Will Lamb. Edinburgh.

Emory Lease. "The Number Three, Mysterious, Mystic, Magic." Classical Philology, 14:56-73.

Dòmhnall Iain MacDhòmhnaill. Fo Sgàil a'Swastika. Inbhirnis: Club Leabhar. 
MacDhòmhnaill 1981

MacDhòmhnaill and Innes 1998

MacDhòmhnaill and Craig 1950

MacDonald and Bruford 1970

Do. MacDonald 1957

Du. MacDonald 1953

MacGillEathain 1954

MacNeil 2011

Matheson 1977

Maurer et al. 2006

Miller and Weinert 1998

Ó Coileáin 1977

Ó Duilearga 1945

Ó hÓgáin 1988

Oakes 1998
Uibhist a Deas. Steòrnabhagh: Acair.

Dòmhnall Iain MacDhòmhnaill and Bill Innes. Chì Mi: Bàrdach Dhòmhnaill Iain Dhonnchaidh. Edinburgh: Birlinn. New ed., 2001.

Dunnchadh MacDhòmhnaill and K. C. Craig. Sgialachdan Dhunnchaidh. Glasgow: Alasdair Matheson.

Donald Archie MacDonald and Alan Bruford. "An Ceatharnach Caol Riabhach." Scottish Studies, 14:133-54.

Donald John MacDonald. “A Plough from South Uist.” Scottish Studies, 1:241.

Duncan MacDonald. Fear na h-Eabaid: The Man with the Habit. Ed. by Angus Matheson and Derick Thomson. Glasgow: University of Glasgow and the British Council. Pamphlet.

Calum I. MacGillEathain. “Aonghus agus Donnchadh.” Gairm, 10:170-74.

Donald MacNeil. Conversation with the author regarding Duncan and Neil MacDonald. Daliburgh, South Uist. 8 July.

William Matheson. "Duncan MacDonald.” Tocher, 25:64.

Hermann Maurer, Frank Kappe, and Bilal Zaka. "Plagiarism-A Survey." Journal of Universal Computer Science, 12:1050-84.

Jim Miller and Regina Weinert. Spontaneous Spoken Language: Syntax and Discourse. Oxford: Clarendon Press.

Sean Ó Coileáin. "Oral or Literary? Some Strands of the Argument." Studia Hibernica, 17/18:7-35.

Séamus Ó Duilearga. "The Gaelic Story-teller: With Some Notes on Gaelic Folk-tales." Proceedings of the British Academy, 31:176-221.

Dáithí Ó hÓgáin. Fionn Mac Cumhail: Images of the Gaelic Hero. Dublin: Gill and Macmillan.

Michael P. Oakes. Statistics for Corpus Linguistics. Edinburgh Textbooks in Empirical Linguistics. Edinburgh: Edinburgh University Press. 
Oakes 2012

Olsson 2009

Patton 1988

Robertson 1976

Robinson and Brown 1926

Rubin 1995

Sanderson 1953

Scott 2011

SQA 2009

Trask 1995

Uther 2011

Zall 1998

Zall 2006-07

Zall 2007-10 "Author Identification, Plagiarism, and Spam." In Second Revised Edition of the Oxford Handbook on Computational Lingistics. Ed. by R. Mitkov. Oxford: Oxford University Press.

John Olsson. Wordcrime. London: Continuum.

Laurie Patton. "Alexander Carmichael, 'Carmina Gadelica,' and the Nature of Ethnographic Representation." Proceedings of the Harvard Celtic Colloquium, 8:58-84.

Hamish Robertson. "Studies in Carmichael's Carmina Gadelica." Scottish Gaelic Studies, 12, ii:220-65.

Edward S. Robinson and Martha A. Brown. "Effect of Serial Position upon Memorization." The American Journal of Psychology, 37:538-52.

David C. Rubin. Memory in Oral Traditions: The Cognitive Psychology of Epic, Ballads, and Counting-out Rhymes. Oxford: Oxford University Press.

Stewart F. Sanderson. Unpubl. letter to John MacFayden, Esq. 26 May. Edinburgh: School of Scottish Studies.

Mike Scott. WordSmith Tools 5. Liverpool: Lexical Analysis Software.

Gaelic Orthographic Conventions. Glasgow: Scottish Qualifications Authority.

Robert Lawrence Trask. A Dictionary of Grammatical Terms in Linguistics. London: Routledge.

Hans-Jörg Uther. The Types of International Folktales: A Classification and Bibliography. 2nd ed. 3 vols. Folklore Fellows Communications, 284-86. Helsinki: Suomalainen Tiedeakatemia.

Carol S. Zall. Mar a Chuala Mi: Remembering and Telling Gaelic Stories: A Study of Brian Stewart. Unpubl. Ph.D. dissertation, University of Edinburgh.

_ "Mouth to Mouth: Gaelic Stories as Told within One Family." Proceedings of the Harvard Celtic Colloquium, 26/27:199-217.

_ . "Variation in Gaelic Storytelling." Scottish Studies, 35:210-44. 
Oral Tradition, 27/1 (2012): 161-170

\title{
Stepping Stones through Time
}

\author{
Emily Lyle
}

\section{Introduction}

Knowledge must be very differently organized in an oral culture than it is in one with writing and, of course, memory is the key. People remember through time, and the memory of an individual is limited in extent. A society may organize itself in such a way as to maximize the common store of what is remembered and may also find ways of setting aside those matters that lie outside its memory range. In this article I aim to formulate a descriptive model for a society that operates in terms of what I call a "memory capsule" of four generations that provides an expectation of recollection over a period of about a hundred years. This model represents a rather static way to speak of the actual human experience that moves forward constantly through time as each generation replaces the one before it, and we should take account of this process, but I have found through the study of Indo-European material, and comparable material from elsewhere, that it is possible to envisage this model in terms of movement through a system of alternate generations, with each of the alternations having its distinctive nature. In the IndoEuropean case, it is proposed that the generations are marked by the central institution of kingship, with each king's reign differing in nature from that of his predecessor and successor. The "stepping stones" of my title suggest a way of grasping this proposed dual movement through time.

\section{Focus on the Oral-Cultural World}

The stress on the written word in the West has meant that we are only belatedly looking into the nature of the oral-cultural world that must have existed before writing came along. It could be argued that scholarship has long taken the historical approach to the Indo-European past too much for granted, and moving toward an oral approach calls for a radical and much more rewarding shift in perspective. A historically known society does not just come out of nothing but has a prehistoric past. We cannot trace this past in any detail before the advent of writing, but what we can reasonably do is build a spatiotemporal model of the posited prehistoric cosmology, resting on folk material and on scraps of information from earlier times (Lyle 1990, 2006, 2007, 2010). It is an orally organized cosmology that provides the foundation from which the diachronic developments that we can document took their rise. The oral-cultural elements found 
in Indo-European societies are not simply offshoots of those processes for which we have early written evidence, but belong to a free-standing oral base to which written elements were later attached. It seems well worthwhile to put effort into grasping the nature of this base. As Walter Ong commented (1982:13): "You cannot without serious and disabling distortion describe a primary phenomenon by starting with a subsequent secondary phenomenon and paring away the differences." We have to attempt to explicate the primary phenomenon of a posited cosmological society in its own terms.

In undertaking study of this kind, it is helpful to consider the operation of oral, or largely oral, societies throughout the world and to use comparative methods of research, as well as seek clues within the wide Indo-European culture area. It should be noted that, even when it is IndoEuropean evidence that gives the possibility of historical depth, the results may be found applicable to other cultures as well.

The current essay pertains to a specific scenario with regard to time, and its basic idea is that people without written records may apprehend a limited segment of linear time and may work to organize and control it in an optimal way. They can achieve such organization by using the time measure immediately available to them, that of human generations. However, because of the wide spread that is possible between births from one couple, a socially agreed upon means of determining the length of a generation is required. In the Indo-European model, a generation coincides with a king's reign that is constrained by an age-grade system and can be postulated as lasting twenty-four years (Lyle 1997). In a system of alternate kingship, each king can marry the daughter of his predecessor, thereby tying the concept in with biological descent within a central family (Lyle 1990:119-33).

A story may help to make the point more vividly and, in fact, it is stories that have carried the mythic information down to us. Oinomaos is king of Pisa and refuses to let his daughter Hippodameia marry any man who cannot defeat him in a chariot race. He has deliberately set this test since he is such a fine charioteer that he is pretty well guaranteed to win. Pelops, however, with divine aid, wins the race and - this is the point - takes over the kingdom from the defeated Oenomaus when he marries his daughter (Frazer 1921:2.156-63). A fresh generation is in opposition to the one before it and displaces it. Pelops is an outsider, but a secure way of keeping a system of alternate kingship like this going in perpetuity is to have two lines of kings derived from a common ancestress and to have matrilineal succession; that feature is built into the model. Some of our earliest Indo-European evidence is from the Hittites and in this context it is possible to see in the historical, and not just the legendary, sources that two lines of males alternate, marrying into the line of queens (Finkelberg 2005:65-89, 177-82). It should be added that a matrilineal way of determining eligibility for kingship does not preclude a strong emphasis on the two royal patrilines. 


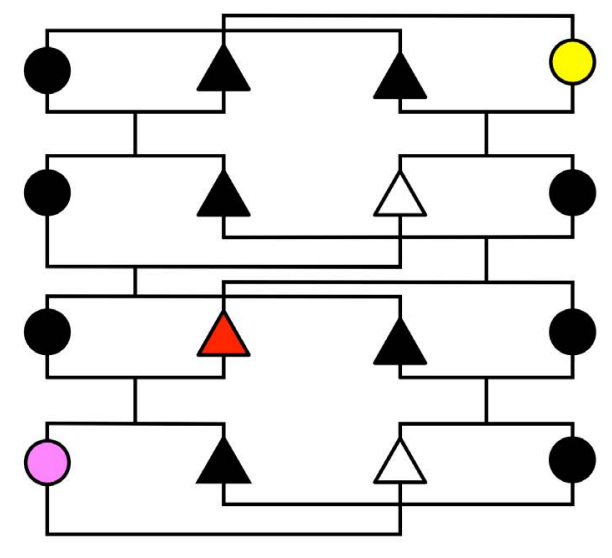

White King

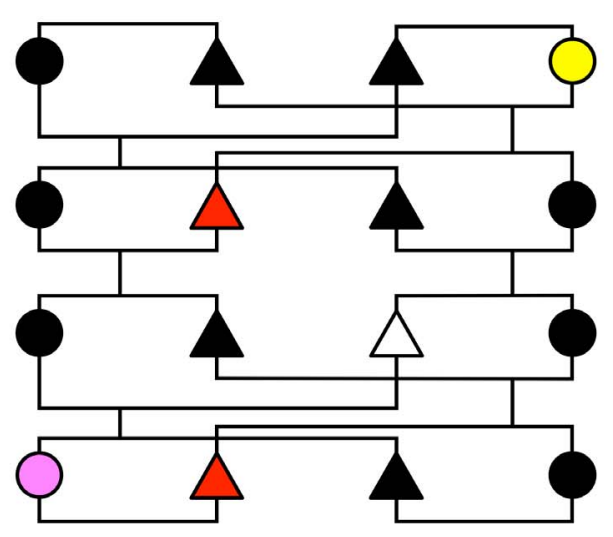

Red King

- Triangles indicate males.

- Circles indicate females.

- Vertical lines indicate decent.

- Horizontal lines above indicate sibling relationships.

- Horizontal lines below indicate marriage relationships.

Figure 1: Alternate forms of the four-generation capsule with bilateral cross-cousin marriage. The kings (white and red) are shown in relation to their ultimate ancestress (yellow), and the previous king's daughter-whom the candidate for kingship must marry—is highlighted in purple.

The model, some parts of which are more firmly grounded than others, operates through a block of four generations that can be called a "four-generation capsule" or a "memory capsule." When we set the model in motion, it moves forward in time by steps of a generation, each of which corresponds to a king's reign, the alternate steps being distinguished as different from each other (see Figure 1). There are accordingly two parallel series that are shown as white and red, colors that can be derived from the Indo-European evidence but that are in any case useful for making the distinction.

If we take the metaphor of stepping stones, a human traverses the immense river of time by placing first one foot and then the other on the stone immediately ahead of the left or right foot. The sequence has to start with one side or the other and it is hypothesized that the first step is taken by the left foot, as illustrated in Figure 2. Of the white and red pair, left corresponds to white and, in the terms used by Georges Dumézil (1958:7, 25-26), to the sacred aspect of society that is at the top of the hierarchy. Any Indo-European structural study today owes a debt to the insights of Dumézil in the twentieth century (Littleton 1982), and his triad of the functions is brought into the discussion below.

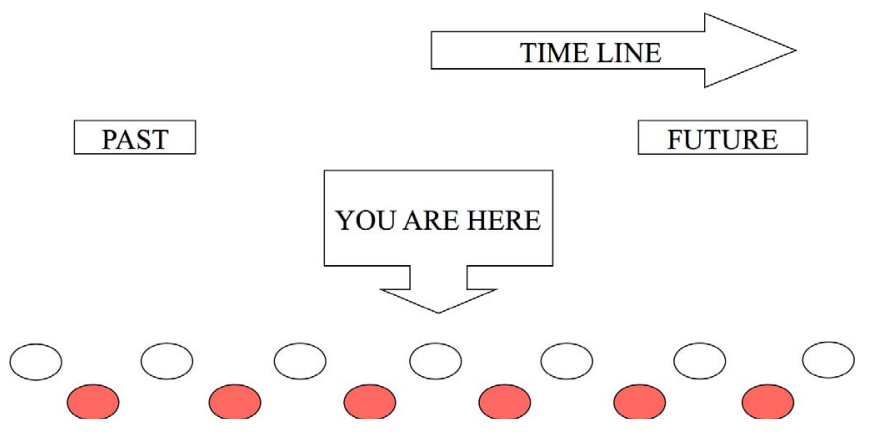

Figure 2: Orientation in time. 


\section{The Indo-European Four-Generation Capsule}

I have called the Indo-European block of four generations a "capsule" to emphasize its isolation as a separate entity. This block is quite evident, but it has not been granted the high importance that it seems to demand, perhaps because the supporting evidence has been dispersed through different subject areas. In the Greek context, Lin Foxhall has drawn attention to the significance of the bilateral kindred (angkhisteia). She writes (1995:134):

Though the angkhisteia is "horizontally" expressed as kinship out to second cousins, "vertically" in time it is those who share great-grandparents. The youngest members are three generations removed from a common ancestral couple whom they probably never knew personally, though their parents most likely did. . . The limits of the angkhisteia become symbolically significant as the temporal and social limits for most of the privileges and responsibilities of kinship.

The Romans also took their ancestry back to the great-grandparents as is apparent in their system of male naming (West 2007:395, n. 59). Foxhall has proposed calling this temporal block "human time" as opposed to the "monumental time" that lies outside it, explaining that the important difference between the two is their varying relationship to memory. Poets have to call on the aid of the Muses for knowledge of monumental time, but there is "no problem with remembering within human time because no one is ever more than one step/person removed from direct access to a particular memory" (Foxhall 1995:135).

A study of Irish and Welsh kinship by T. M. Charles-Edwards concludes that there was a Common Celtic kinship unit of the "true kindred" (derbfine) that consisted of a descent group of four adult generations. Horizontally this group extended to second cousins, and the unit thus corresponds to the Greek angkhisteia. There are indications in addition of an extended lineage of indefinite length that had different functions (Charles-Edwards 1993:55, 187, 213-14, 471-72). The similar Indian sapinda system also adds to our understanding since it specifically includes mention of a man of the living generation and of three generations of the dead (Dumont 1980). The pinda is a ball of rice and a man offers three pindas, one each to his deceased father, grandfather, and greatgrandfather. There is a sharp cut-off point when a former named ancestor joins the ranks of the

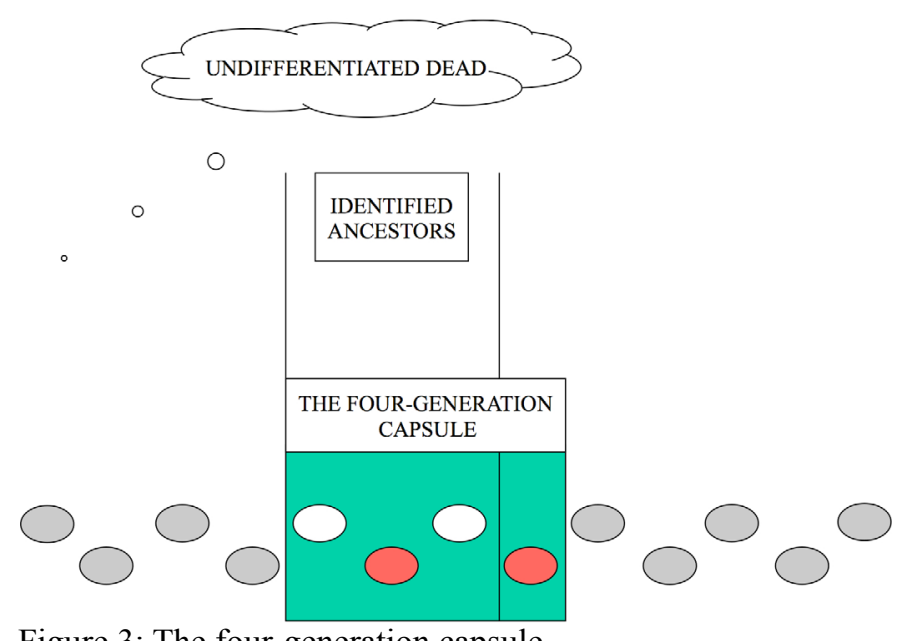

Figure 3: The four-generation capsule. undifferentiated dead, and we can see clearly that this implies the existence of a culturally defined memory span (see Figure $3)$.

It should be noted that the IndoEuropean evidence for the four generations drawn on in these instances goes back patrilineally to an ancestor, whereas in the modelled cosmology, which is assumed to relate to a period in prehistory, it is an ancestress rather than an ancestor who plays a key role so far as royal succession goes. 


\section{Alternate Generations and a Fourfold Cycle}

One of the breakthroughs that allowed assumptions about Indo-European structures to be broken down and re-assembled was Kim McCone's interpretation of the triad of "functions" (the sacred, the physical force, and fertility) that Dumézil (1958:18-19) had found among the IndoEuropeans. McCone argued (1986 and 1987) that this triad related to the life stages of old men, youths, and mature men in an age-grade system of which he found traces in the Indo-European historical record. Following up on this assertion, I explored the Indo-European materials in the light of the structures found among East African pastoralists more fully than McCone himself had done and showed how the Indo-European pattern of four - relating to the four directions of space-could be reconciled with the threefold system recognized by Dumézil (Lyle 1997). This reconciliation can be accomplished by considering the system of the Maasai, for whom at any one time there are four age-classes present in the society: the unmarried young men called moran, the mature men in the period just after marriage called "elders," the mature men later in life who can be called "firestick elders," and the old men referred to as "senior elders." When men move up from one class to another, the change affects the whole of the system simultaneously since each class has to be of the same size. However, the mature men are present in two classes and so form a half of the system. There are three life stages-youths, mature men, and old men (corresponding to the three functions in the order of physical force, fertility, and the sacred) - but there are four classes since the "mature men" group consists of two classes. So, study of age-grading in East Africa supplied an answer to the puzzle of the apparently conflicting threefold and fourfold sets (Lyle 1997).

The threefold nature of some of the East African age-grade systems can be related to the structure of alternate generations, with the mature men belonging to one generation alternation and the young and old men belonging to the other. The systems of the Turkana and Karimojong, for example, have clearly marked generational alternations, a fact I observed in relation to the posited Indo-European alternate succession over twenty years ago (Lyle 1990:121-22):

\footnotetext{
North-East Africa provides a number of cases of another institution [besides alternate royal succession] relevant to this discussion, that of alternating generation sets. I will take two examples where the alternate generations are identified by colour since I will be referring to colour in the Indo-European context. Among the Turkana, there are two groupings or alternations. Every male child at birth automatically becomes a member of that of his grandfather, and is therefore in the opposite one from his father. The members of the alternations are called the Stones, who are especially associated with black ornaments, and the Leopards, who are especially associated with white ornaments (Gulliver 1958). Among the Karimojong, those belonging to one of the two alternate generation sets are referred to as yellow and wear brass ornaments, and those of the other are referred to as red and wear copper ornaments.
}

Neville Dyson-Hudson, who has written extensively about the Karimojong, describes how membership in one or another of the alternations is shown outwardly by the wearing of such ornaments (1966:176): 
Ornaments are distinguished as "red" (copper) and "yellow" (brass) and take the form of earrings, bracelets, forearm-clasps, and finger rings. Members of a generation-set may wear only ornaments of the colour appropriate to them, and the neck rings worn by their wives are similarly restricted.

I was evidently skirting a potential problem when I avoided mentioning the names of the alternations among the Karimojong since there was controversy on this point. Dyson-Hudson held that there was a cycle of four named generations that related alternately to the two colors, but his view was challenged by John Lamphear, who had made a study of the Karimojong as well as the neighboring Jie people and doubted the existence of a fourfold cycle (1976:35-37; 43, n. 44). I did not follow up on this debate at the time, but the possibility of such a fourfold cycle came to my attention again recently when reading a study by Wendy James, who drew on Dyson-Hudson for the Karimojong and on Malcolm Ruel for the Kuria of Tanzania and Kenya to demonstrate a recurrent cycle of four generation-sets paired alternately (2008:87-92). It seems that the Karimojong, strictly speaking, may actually have a twofold rather than a fourfold cycle (Knighton 2005:137; 146, n. 27), but Ben Knighton, who makes this point, implies that there is still a fourfold schema of some kind by commenting that the pattern in the informants' minds of an order of creation laid out in fours like the world directions "easily leads to seeing the generation-sets in a cycle of four" $(137, \mathrm{n}$. 10). It would obviously be desirable to explore this point further, for it may have a more general application, and it is certainly suggestive for the Indo-European situation to which I shall now turn.

The presence of four parts (the four generations of the memory capsule) but with a switch between only two possibilities (the institution of alternate kingship) is just what has emerged in the Indo-European case, and we can consider how the members of a cycle of four generations might have been identified if found in connection with such a system. The answer seems to be that the Indo-Europeans would have used color throughout since there is evident use of a fourfold color set. Three of the four colors are those of the basic color triad, with white relating to the sacred (and priests), red to physical force (and warriors), and black/blue to fertility (and the cultivators, cattleowners, and the like). The fourth color is yellow in the Indian context, where the sequence is given as white, red, yellow, and black/blue both in the vertical series of the parts of the body of the cosmic man and on the horizontal plane in association with the world quarters. The equivalent to yellow in the color set found in the context of the Roman circus is green. In our terms, the colors yellow/green and black/blue can both relate to the third function since it has two components.

The Roman circus has been interpreted cosmologically, and the charioteers belonged to one of four factions distinguished by color that prove very interesting in connection with this discussion of twofold and fourfold cycles. The colors fall into two pairs with a dominant and subordinate partner in each case: dominant blue is paired with white, and dominant green is paired with red (Lyle 1990:35-47). It can be argued that white and red were the primary colors at an earlier stage than we have direct knowledge of, perhaps at the time before Rome drove out its kings (Tertullian, De Spectaculis 9; Lyle 1990:45-46), and I shall take these colors here as the dominant members of the pairs. In the generation sequence, we can start with the two dominant colors, white and red, and then, to keep up the alternation, we have black/blue (partner of white) and yellow/green (partner of red) as shown in Table 1 . 
Table 1: The Color Categorization of the Two Alternations and Four Generations.

\begin{tabular}{|l|l|}
\hline Indo-European royal alternations & Indo-European qualities of the reigns \\
\hline white & white, magical force \\
red & red, physical force \\
white & black/blue, fertility of water \\
red & yellow/green, fertility of earth \\
\hline
\end{tabular}

The sequence revolves, and each generation as it comes along enters into one of the four pre-established identities that would not be just a matter of color but would foreground certain qualities. The result would be that each king's reign is tagged separately in the sequence and forms a memory slot with a distinctive flavor. The qualities proposed here are those of the three functions as discussed by Dumézil, but with the third function falling into two parts. In identifying their separate characteristics I am drawing on a unique representation of the Oinomaos/Pelops chariot-race as a ritual contest in which blue is associated with Poseidon and the produce of the sea while green is associated with Demeter and the produce of the land (Lyle 1990:130-31). A fourfold cycle structured in this way with the alternate generations linked together is also found among the Kuria (Ruel 1962, 1997), although they do not have color identifications for the alternations as the Turkana and Karimojong do.

The proposed Indo-European age-grade system (partially based on Maasai practice) has four half-classes in each generation set and, if the initiations are hypothetically placed every six years, we have a generation length of 24 years and a fourfold cycle lasting 96 years. The period of the four-generation capsule, whatever its precise length, is a limited one and the time before it is likely to be predominantly a place of myth and legend rather than of history. Dyson-Hudson finds that the Karimojong are preoccupied with immediate events and immediate relationships and that "beyond that recent point from which descent relationships are periodically recalculated, the past holds little interest for individuals" (1963:399); "they either incapsulate the past into present relationships or release their hold on it altogether" (1966:258).

\section{Conclusion}

Indo-European heritage places importance upon a set of four generations, and this would seem to be an important factor that affects understanding of the role of human memory in the organization of its associated oral culture. The existence of a four-generation set implies a shifting shallow lineage, each fresh generation of which can metaphorically be called a "step" into the future as it differs from the one before it and resembles the grandparent generation. James spells out some of the implications of attempting to grasp a system such as this (2008:87):

The logic of alternating birth classes . . cuts across what is widely supposed to be the "natural" side of social reproduction. It cuts across the common descent supposed between parent and child, assigning these to quite separate and opposed, ontological kinds. In theory, alternating birth classes 
and descent lines are rather different conceptions of continuity. But they do occur together in practice, and ethnographers have therefore tried to represent their workings- "hybrid" systems as often as not-as functional wholes based on a common logic. This is why both the primary ethnography and secondary commentaries are so complicated.

This hybridity is also the reason why it is such a complicated task to model a structure that takes into account the specific features of an Indo-European "ethnography" that has come down to us only in fragmentary form. We can see that it is a "hybrid," but we cannot assume that the particular features of importance to the Indo-European cosmology have been drawn upon in quite the same way within any current society. The components are likely to be present, but the particular makeup could be unique. A total Indo-European system is not present to be observed, as is also sometimes the case in ethnographies of recent cultures that have been subject to fragmentation. Putting the pieces together differs in extent but not in kind from what is being done by anthropologists who have been able to undertake fieldwork or are interpreting the work of predecessors who have done so in the relatively recent past. The apparently "safe" approach of going back through the historical evidence is therefore not really so if it is built on a misunderstanding of how societies without writing operate. As James notes (2008:85), in order to grasp the essentials, we first "need to defamiliarize ourselves from what might seem normal and reasonable" in the current Western context.

University of Edinburgh

\section{References}

Charles-Edwards 1993

Dumont 1980

Dumézil 1958

Dyson-Hudson 1963

Dyson-Hudson 1966

Finkelberg 2005
T. M. Charles-Edwards. Early Irish and Welsh Kinship. Oxford: Oxford University Press.

Louis Dumont. "La dette vis-à-vis des créanciers et la catégorie de sapiṇ̣a." Purușārtha: sciences sociales en asie du sud, 4:15-37.

Georges Dumézil. L'idéologie tripartie des Indo-Européens. Collection Latomus, 31. Brussels: Latomus.

Neville Dyson-Hudson. “The Karimojong Age System.” Ethnology, 2:353-401. . Karimojong Politics. Oxford: Clarendon Press.

Margalit Finkelberg. Greeks and Pre-Greeks: Aegean Prehistory and Greek Heroic Tradition. Cambridge: Cambridge University Press. 
Foxhall 1995

Frazer 1921

Gulliver 1958

James 2008

Knighton 2005

Lamphear 1976

Littleton 1982

Lyle 1990

Lyle 1997

Lyle 2006

Lyle 2007

Lyle 2010
Lin Foxhall. "Monumental Ambitions: The Significance of Posterity in Greece." In Time, Tradition, and Society in Greek Archaeology. Ed. by Nigel Spencer. London: Routledge. pp. 132-45.

James George Frazer, ed. and trans. Apollodorus of Athens. The Library. London and New York: William Heinemann and G. P. Putnam's Sons.

P. H. Gulliver. "The Turkana Age Organization." American Anthropologist, 60:900-22.

Wendy James. "Alternating Birth Classes: A Note from Eastern Africa." In Early Human Kinship: From Sex to Social Reproduction. Ed. by Nicholas J. Allen, Hilary Callan, Robin Dunbar, and Wendy James. Oxford and Malden, MA: Blackwell Publishing. pp. 83-95.

Ben Knighton. The Vitality of Karamojong Religion: Dying Tradition or Living Faith? Aldershot and Burlington, VT: Ashgate.

John Lamphear. The Traditional History of the Jie of Uganda. Oxford: Clarendon Press.

C. Scott Littleton. The New Comparative Mythology: An Anthropological Assessment of the Theories of Georges Dumézil. 3rd ed. Berkeley: University of California Press.

Emily Lyle. Archaic Cosmos: Polarity, Space, and Time. Edinburgh: Polygon. "Age Grades, Age Classes, and Alternate Succession: A Restatement of the Basis at the Societal Level of Indo-European Symbolic Partition." Emania, 16:63-71. . "The Importance of the Prehistory of Indo-European Structures for IndoEuropean Studies." Journal of Indo-European Studies, 34:99-110. . "Narrative Form and the Structure of Myth." Folklore: Electronic Journal of Folklore, 33:59-70. http://www.folklore.ee/folklore/vol33/lyle.pdf . "The Cosmological Theory of Myth." In New Perspectives on Myth: Proceedings of the Second Annual Conference of the International Association for Comparative Mythology, Ravenstein (the Netherlands), 19-21 August, 2008. Ed. by Wim M. J. van Binsbergen and Eric Venbrux. Haarlem: Shikanda. pp. 267-77. http://www.quest-journal.net/PIP/New_Perspectives_On_Myth_2010/ New_Perspectives_on_Myth_Chapter13.pdf 
McCone 1986

McCone 1987

Ong 1982

Ruel 1962

Ruel 1997

West 2007
Kim McCone. "Werewolves, Cyclopes, Dibergs, and Fianna: Juvenile Delinquency in Early Ireland." Cambridge Medieval Celtic Studies, 12:1-22.

. "Hund, Wolf und Krieger bei den Indogermanen." In Studien zum indogermanischen Wortschatz. Ed. by W. Meid. Innsbrucker Beiträge zür Sprachwissenschaft, 52. Innsbruck: Institut für Sprachwissenschaft der Universität Innsbruck. pp. 101-54.

Walter Ong. Orality and Literacy: The Technologizing of the Word. New York: Methuen.

Malcolm Ruel. "Kuria Generation Classes.” Africa, 32:14-37.

Belief, Ritual, and the Securing of Life: Reflexive Essays on a Bantu Religion. Leiden and New York: E. J. Brill.

Martin L. West. Indo-European Poetry and Myth. Oxford: Oxford University Press. 
Oral Tradition, 27/1 (2012): 171-186

\section{Dipping into the Well: Scottish Oral Tradition Online}

\section{Cathlin Macaulay}

Scotland has a long history of collecting material from its oral traditions as illustrated by the various manuscripts and publications of songs, tales, and verse that have appeared from the sixteenth century onwards in the languages of Gaelic, Scots, and English. For a small country, Scotland's influence has stretched widely, particularly from the 1760s onwards with the publication of MacPherson's Ossian, a literary creation in English drawing on oral tradition from Gaelic-speaking Badenoch. The text was seminal to the European Romantic movement and the antiquarianism of that and the following centuries, and there has been much debate as to its "authenticity," which continues even to the present day. Collectors in Scotland have come from all walks of life, from aristocrats and landed gentry such as Lady Evelyn Stewart Murray (1868-1940), sister of the Duke of Atholl, who collected Gaelic tales from people working on the family estate in Perthshire, ${ }^{1}$ to those born into much poorer circumstances such as Robert Burns (1759-1796), son of a tenant farmer, who collected material for the Scots Musical Museum (1787-1803), songs and airs that attracted the interest of composers such as Haydn and Beethoven. Most of the collectors, though, appear to have been from the "professional" classes, principally teachers and preachers. They were literate and therefore able to create texts of the oral material, and their roles gave them access as "insider-outsiders" to the communities in which they were located.

Verse and song were the primary interests in the early period, and in Gaelic these are virtually interchangeable. But by the nineteenth century the field had opened up, and tales, customs, and beliefs began to feature more strongly. During this century there was also a growing awareness of presentation and the uses to which the material could be put. Whose account was presented? John Francis Campbell of Islay (1822-1885), who collected Gaelic tales, was a strong advocate of verbatim transcription and publication. In his introduction to Popular Tales of the West Highlands, in which he discusses the new science of "storyology," he indicates (1890:iii):

... it seemed to me as barbarous to "polish" a genuine popular tale, as it would be to adorn the bones of a Megatherium with tinsel, or gild a rare old copper coin. ... [S]tories orally collected can only be valuable if given unaltered....

${ }^{1}$ The manuscripts are held in the School of Scottish Studies Archives and were published in 2009 as Tales from Highland Perthshire Collected by Lady Evelyn Stewart Murray (Robertson and Dilworth 2009). 
He worked with a team that included John Dewar, a laborer, Hector Urquhart, a gamekeeper, and Hector MacLean, a schoolmaster. Campbell would make spot checks of their transcriptions by comparing them with the original sources to see how accurate they were. The tales were published as transcribed.

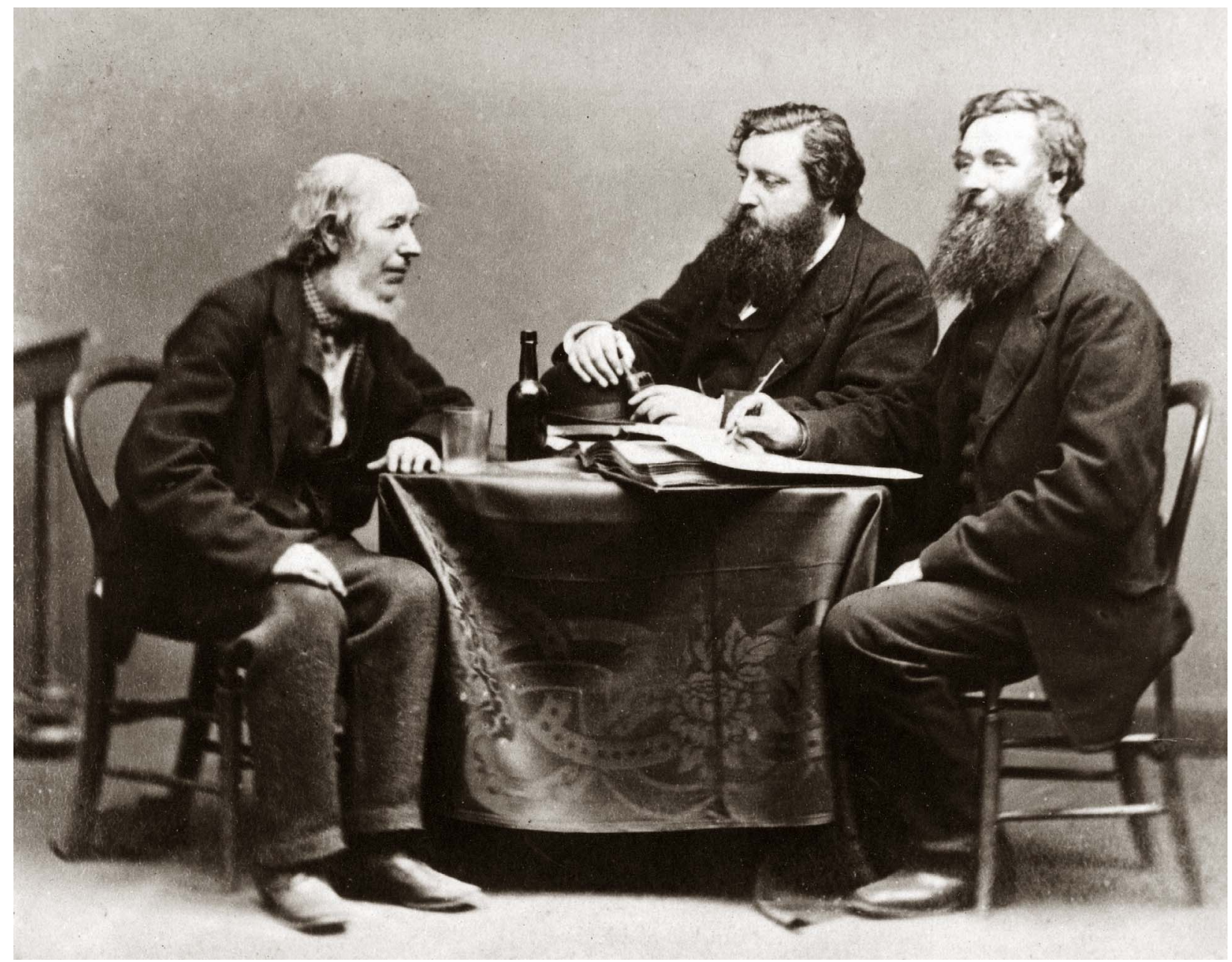

Image 1. Lachlan MacNeill, John Francis Campbell, and Hector MacLean, Islay, 1870 (School of Scottish Studies Archives).

Other individuals, while taking what appear to be relatively accurate transcriptions, published quite different versions. For example, Alexander Carmichael (1832-1912), author of Carmina Gadelica, a collection of Gaelic folklore, would sometimes make a collation from several original oral sources. Often these re-renderings would be done in the literary language of the time-moving ever further from the verbatim account.

The beginning of the twentieth century brought the use of sound recording equipment for the purpose of collecting. Gaelic songs were the main focus, with recordings made from 1907 onwards by Rudolf Trebitsch (1876-1918), an Austrian ethnologist; Lucy Broadwood (1858-1929), who was much involved in the Folk Song Society in England and worked in Arisaig; and Marjory Kennedy-Fraser (1857-1930) from Perth, who collected in the Hebrides. 
While it appears that Trebitsch was interested in "rescue ethnology," particularly in relation to endangered languages, Kennedy-Fraser was concerned not with the material per se, but with recreating it in the form of "artsongs." She would revamp the airs according to a western mode and use, to our ears, sometimes rather florid translations of the Gaelic originals, publishing these as Songs of the Hebrides and performing the songs around the world. During the 1920s and early 1930s James Maddison Carpenter (1888-1983) visited from the United States with his Dicataphone cylinder machine, recording traditional Scots songs and customs. Later in the 1930s and 1940s Margaret Fay Shaw (1903-2004) and John Lorne Campbell of Canna (1906-1996) were active in collecting songs and tales from the islands to the west of Scotland, mainly the Uists and Barra. Using the media of wax, wire, and disc, Campbell was conscious of the value of the oral tradition and published textual material and sound recordings from the original contributor more or less as they stood.

While there was a lot of activity, collectors operated as individuals rather than through any institution. The impetus for the establishment of an institute focusing on collecting and researching oral tradition came from various sources. With the end of the Second World War, there was great dialog and debate regarding the nation's identity. Interest in Scotland's oral tradition led to the setting up of the Folklore Institute in 1947 by John Lorne Campbell and others. In 1949 Angus McIntosh, Forbes Professor of English Language and General Linguistics at the University of Edinburgh, set up the Linguistic Survey of Scotland. McIntosh had worked during the war on code-breaking activities in Bletchley Park and welcomed the opportunities provided by the new technology of the time, the open reel recorder, soon to take over from wax cylinder, wire, and disc. His specialist subject area was dialectology, and he was keen to widen the context of his work through the collection of "natural speech" in context rather than focusing entirely on phonetic transcription of word lists. There was an international impetus, too. Ireland and Scandinavia had much in common both linguistically and in terms of folklore with Scotland, and were keen to foster links. James Hamilton Delargy, Head of the Irish Folklore Commission established by the Irish government in 1935, and Dag Strömbäck of the Institute for Dialect and Folklore Research in Uppsala, Sweden, founded in 1914, expressed strong support for having an institute that, so to speak, straddled the Norse and Celtic worlds.

With this support, the School of Scottish Studies was established in 1951 at the University of Edinburgh as a research institute concerned with what was then termed "folklore" and "folk life." Stewart Sanderson, the first archivist, described the area of study as follows (1957:6):

The study of folklore is, in fact, the study of a certain kind of history; the intimate domestic history of a people. History is not just a matter of kings and queens, battles and treaties, statesmen and parliaments, these are certainly important, moving as they do in splendid and colourful succession into the highlights of time; but they play their part against a more enduring background. Behind them and around them lies the less spectacular but more lasting history of a people's beliefs and customs, notions of right and wrong, good and evil, luck and ill-luck, happiness and sorrow, songs and stories, facts and fancies - all the common places which make up the intricately patterned fabric of our environment. It is this kind of history with which the student 
of folklore is concerned. . . The study of folklore begins with the individual and his local and personal heritage of tradition.

This seems a good description of the kind of material collected for the School, though nowadays we might use terms such as "ethnology" and "traditional arts"- there have been various debates regarding nomenclature over the years. Researchers were employed according to their special area of interest: song, music, oral narrative, place-names, customs and beliefs, social organization, and material culture. The first fieldworker, Calum Maclean, dispatched from the Irish Folklore Commission, spent time in Uppsala learning about their archiving and indexing techniques, so there was a continuum of classification between the three archives. Maclean, a native of Raasay, an island off Skye, was himself descended from a family of tradition bearers, and his brother, Sorley, became a celebrated modern Gaelic poet. He was closely followed by Francis Collinson, a composer and musicologist who had worked with the BBC, and Hamish Henderson, who had seen war service in North Africa and Italy and had published a prizewinning collection of poetry based on his experiences. He later became known as the "father" of the folk revival in Scotland. In the summer of 1951, Maclean and Henderson escorted American song hunter, Alan Lomax, around Scotland on his mission to create and publish a library of world folk music.

The early expeditions from the School might be described as "rescue ethnology" in the sense that they focused on rural areas, farming, fishing, and crofting communities where, due to the sweeping changes after the war, local traditions and dialects were dying out. It should be pointed out, though, that over the centuries many collectors of oral tradition have done such work, confident that they are collecting the last gasps of a dying culture.

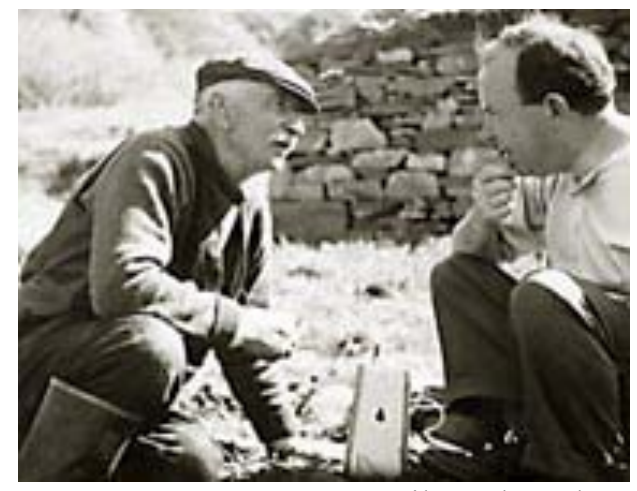

Image 2. Angus MacNeil and Calum Maclean, Smearisary, 1959. Photo by Ian Whitaker (School of Scottish Studies Archives).

Fieldworkers made recordings in people's homes, at ceilidhs, and sometimes, literally, out in the fields, building up a collection of some 12,500 tapes. In the early days, the School had decided to make the original audio rather than written transcription the main resource, a practice made possible by the innovation of open reel tape that was cheaper and more stable than earlier formats. With the unembellished voices of the contributors as the primary record, the integrity and authenticity of the original voice is unquestionable. Transcription is, by its nature, subjective. It always takes on a flavor of the transcriber, and written forms cannot convey the aesthetic or emotional expression of the voice. Preservation of the original sound recordings is an invaluable historical record; the archive becomes evidence, inviolate to literary tinkering. Of course, debates as to original sources of the actual material remain - whether, for example, a particular heroic ballad may have been transmitted solely through the oral tradition or has, at some point, re-entered it via textual intervention.

The subject matter of the sound archive covers all aspects of cultural life and the traditional arts, with much of the material in Gaelic and Scots. There is a good-sized collection of 
tales and stories, including a notable contribution from Scottish Travellers. There are heroic narratives (some of which have been transmitted orally from medieval times), wonder tales, migratory legends, supernatural stories, and accounts of historical events and clan battles, as well as local tales and anecdotes, often humorous, from various communities, celebrating local individuals and events. Accounts of traditional life include information about work and home from the beginning of the twentieth century: farm servants' lives, the herring industry, fowling, fishing, house construction, furnishings, food, recipes, herbal cures, weather lore, Hogmanay, Halloween customs, Galoshins (a folk play), birth and marriage traditions, charms, blessings, the agricultural year, and the rhymes, proverbs, and sayings that are part of the rituals of sowing and harvesting. In recent years there has been a move away from "rescue" collecting toward the ethnology of contemporary life in Scotland. Studies include storytelling contexts, the heritage industry, Internet use, neo-paganism, the re-invention of tradition, Beltane ceremonies, clubbing, Goth culture, and divination using soda cans. Much of this work has been undertaken by students of Scottish Studies and Scottish Ethnology who are trained, as part of their studies, in fieldwork techniques.

The archive holds thousands of traditional songs in Scots and in Gaelic. These include waulking songs, puirt-a-beul (mouth music), laments, lullabies, work songs, political songs, bothy songs, sea songs, emigrant songs, nursery rhymes, children's games, muckle sangs (the great narrative ballads), and love songs. Many of these songs also appear in manuscripts compiled over the past couple of centuries, thus allowing opportunities for comparative and longitudinal work. From musicians there is a large repertoire of pipe and fiddle music and contributions from jaw harp, clarsach, and whistle, as well as ceilidh and dance bands.

The fieldwork collection includes recordings from the Gaelic and Scots Linguistic Surveys of Scotland and from the Scottish Place-Name Survey, which uses maps along with tapes for documenting the pronunciation and lore of places. Additional donated material includes oral history projects and published recordings of music and song from individual collectors. There is a small film and video archive featuring storytellers, singers, and traditional crafts such as basket-weaving, thatching, and stilt-making. The photographic archive focuses on ethnological fieldwork, with thousands of images, including significant collections from Robert Atkinson (1915-1995) and Werner Kissling (1895-1988). The manuscript archive contains many items drawn from oral tradition, and the ethnographic research library has built up a considerable collection of published resources serving to contextualize the fieldwork collections.

Over the past sixty years, technology has changed considerably from the cumbersome open reel, weighing almost as much as a sack of coal, to pocket-sized digital recorders. The recordings have been carefully stewarded and, in recent years, stored in environmentally controlled conditions. However, tapes do not last forever, and each generation of an analog recording is of poorer quality than the last. Preservation is a central aspect of archive work. So too is enabling access - a process that encompasses such tasks as the creation of mechanisms by which users can search for and listen to material. There are many visitors to the archive, including scholars, students, singers, musicians, storytellers, historians, teachers, and broadcasters. Material is especially important to the relations and communities of those recorded. However, the archive is situated in Edinburgh, well away from the areas in which most of the collections were made. The School has attempted to make the material as accessible as possible, 
and publication strands include the Scottish Tradition series of audio recordings now published through Greentrax and Tocher, a journal that contains transcriptions and translations of archive material. In the 1990s a small prototype website was developed, one of the very first audio online resources, entitled PEARL (Providing Ethnological Access for Research and Learning) in which written transcriptions from Tocher were linked to the original audio (http:// www.pearl.arts.ed.ac.uk). Voices were digitized and made accessible to all. This website provided proof of concept for a larger project conceived towards the end of the decade. The project, entitled Tobar an Dualchais ("Well of Heritage") in Gaelic and Kist o Riches in Scots, incorporates three archives - the School of Scottish Studies; the National Trust for Scotland's Campbell of Canna Collection, Gaelic songs, and tales collected by John Lorne Campbell in the Hebrides and Nova Scotia from the 1930s onwards; and complementary material from BBC Alba, the Gaelic radio archive (http://www.tobarandualchais.co.uk and http:// www.kistoriches.co.uk).

The project was administered through Sabhal Mòr Ostaig, the Gaelic medium college that is part of the University of the Highlands and Islands, and the remit of the project, which commenced in 2006, was to digitize 12,000 hours of material and create online access. The development of databases and a website was undertaken by EDINA at the University of Edinburgh. Funding came mainly from the Heritage Lottery Fund matched by a combination of other sources including local authorities, the University of Edinburgh, the Scottish Executive, and the European Regional Development Fund.

Preservation has been a very important aspect of the project. Though the School of Scottish Studies houses tapes according to the recommended environmental conditions-cold and dry - they deteriorate much more quickly than paper. Digitization enables the material to be transferred to another medium that can be managed and migrated as appropriate without further loss of quality. The variety of formats requiring digitization have included wax cylinder, wire, disc, many hours of open reel tapes, and the more recently used DAT and Minidisc.

Specialists were employed to deal with the obsolete formats and two digitization centres were set up to work with tapes, one on the island of South Uist and another in the School of Scottish Studies Archives in Edinburgh. 


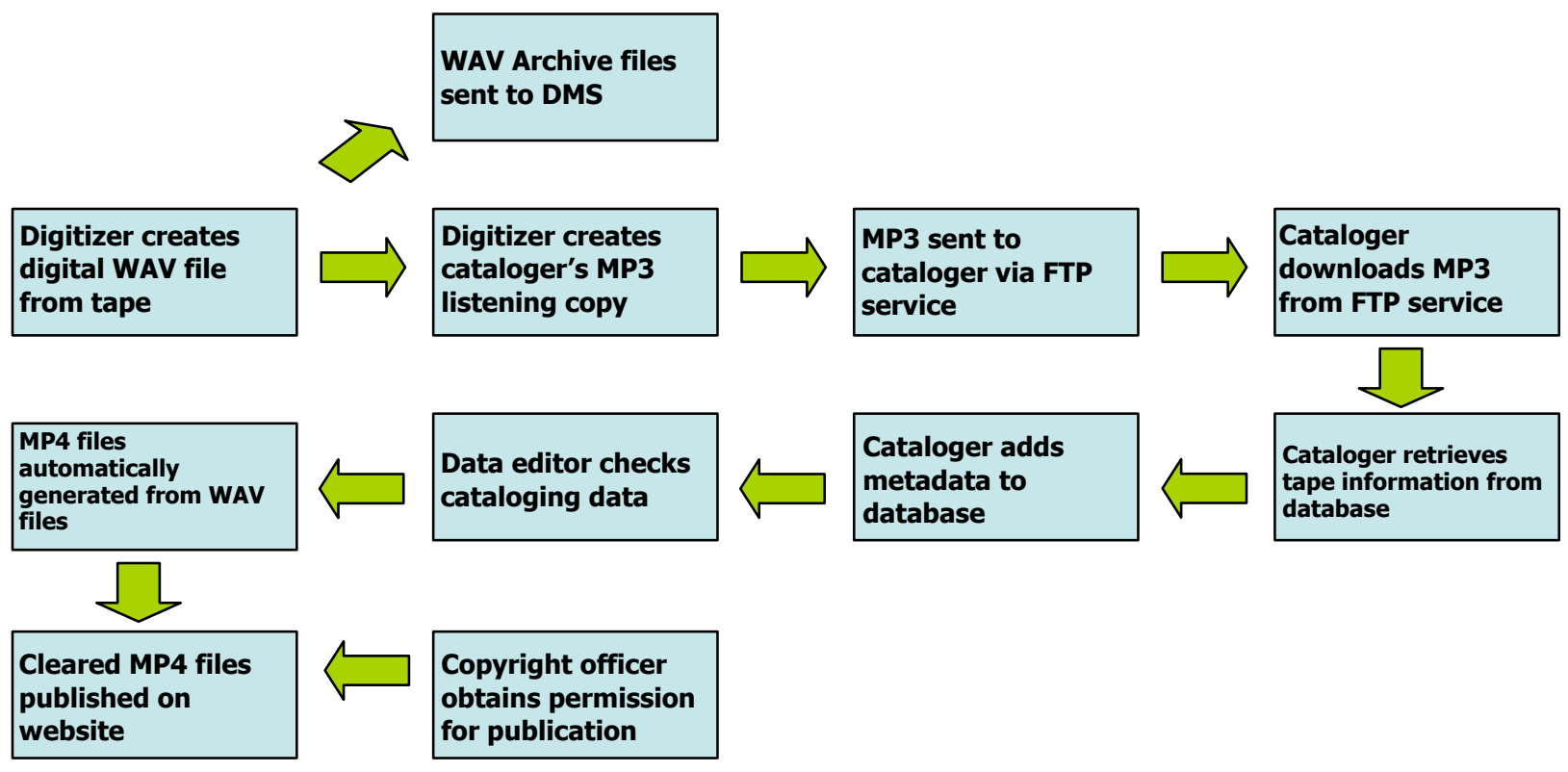

Diagram 1. Tobar an Dualchais: Process of digitization

Digitizers created high resolution WAV files $(96 \mathrm{kHz}, 24-\mathrm{bit})$ to the international standard defined by IASA (International Association of Sound and Audio-Visual Archives). These archival files are now preserved in a digital mass storage system at the University of Edinburgh. MP3 copies of the files were created for access purposes - these were used in the creation of the online resource and are now used in-house in the archive search room where a streaming facility has subsequently been developed. Prior to this conversion, visitors had to use open reel tape recorders.

Digitization was a fairly straightforward process once procedures had been put in place. Cataloging the material for online access has been much more complex. One of the primary roles of the project was to create work in rural areas where economic and employment opportunities have been limited, and it is also important in archival terms that the material is cataloged by those who have some knowledge of the content or the community from which it originates. Many of the practices described no longer exist, and there are songs, tunes, and tales that may not have been heard for decades. The use of Scots and Gaelic has also diminished since the material was originally recorded. In the end, some thirty catalogers have been employed on a part-time basis during the course of the project. Selected for their expertise, they included Gaelic and Scots singers and musicians as well as those with knowledge of local history and dialect. Catalogers worked at home and were spread throughout the country. Everything was dealt with electronically - each cataloger using a laptop to receive and generate material. They accessed MP3 files through a web-based browser, tracking the audio and adding metadata about the content to a custom-built database. MP4 tracks were cut for public use on the Internet according to the timings supplied by the catalogers, and descriptive metadata was checked and proofread by a data editor before publication could be authorized.

The descriptive metadata for each item includes information on duration, the contributor, the fieldworker, and the date of recording. Details of place include parish, county, and township, 
enabling material to be compared with other historical records, for example, parish records and the Statistical Accounts of Scotland. Details on the subject matter include genre, a summary of content, and subject classification. Gaelic material was cataloged and summarized in both English and Gaelic. Scots and English material was cataloged only in English, though index keywords may be applied bilingually, thus enabling English or Scots material to be searched through Gaelic.

Classification of subject matter has proven challenging. There has been a great cultural shift since the 1950s. Many of the ways of life described in the recordings are no longer familiar to people - words referring to particular ways of doing things have been lost or have taken on new meanings. As befits an ethnological archive, much of the material is particular to the culture, and general classification schemes such as Library of Congress subject descriptions are, in their attempt at universality, too broad. Specialist, subject-based thesauri can be too specific or technical. The main aim of the project has been to produce an educational resource. The website has to reach out to children and those who, though Internet savvy, are not used to searching for material in archives. To this end, an in-house classification that reflects the material was prepared, and a general browsing menu was developed along with an index of key terms.

The use of a bilingual interface is one of the most innovative aspects of this project, enabling the "voice" in its broadest sense to take primacy-but it has proven challenging. There are conceptual differences and nuances between Gaelic and English such that direct translation is a difficult, sometimes impossible, process. Differences in word order mean that there may be a different emphasis in compound terms, and spellings in Gaelic vary according to relation. In addition Gaelic has pronounced dialectal differences and has undergone orthographic modification twice over the last thirty years - searchers will sometimes have differing notions as regards meaning and spelling of individual terms. There was a question as to whether the website should be trilingual to encompass Scots as well. However, debate around what constitutes Scots is ongoing. It too has distinctive dialectal differences, but because there is no written standard, it would be impossible to create a list of terms that was both comprehensible and accommodating of every dialect. ${ }^{2}$ Understanding and cataloging the material could be quite difficult, hence the value of using catalogers with some expertise in the subject matter, locality, and language used. Ultimately, of course, the voice is the primary source material and cataloging a means of finding it rather than interpreting it.

Another hurdle has been that of copyright. When the bulk of the material was collected, it was done for research purposes. There was no anticipation that the World Wide Web would ever exist, and copyright law at that time was not nearly as rigorous as it is now. While the archive holds copyright on recordings made by its fieldworkers, the contributor generally still holds copyright on their own words. For the purposes of the project, dedicated copyright officers were employed to track down the contributors. Finding individuals who gave material some fifty years ago or, as is often the case, their next of kin is extremely time consuming and sometimes impossible. There are interesting ethical issues, too. Much of the material given to the archive may be regarded as "community" heritage or knowledge rather than as belonging to one

${ }^{2}$ For a history of Scots see Macafee 2003 and Aitken 1985. Further information on issues to do with the language can be found in Corbett et al. 2003, on the Scots Language Centre website (http:// www.scotslanguage.com), and through the Dictionary of the Scots Language website (http://www.dsl.ac.uk/). 
individual, yet it is the individual contributor who is regarded as the "owner." Should access to material be prohibited because the legal owner cannot be traced? On the other hand, none of the individuals who contributed could have expected their performance to be accessible so far from their own community, potentially to millions of people they did not know and would never meet. It seems fair that this re-purposing should involve informed consent, as Donald Archie MacDonald pointed out (1972:426):

These men and women who have given so freely of their time, their enthusiasm, and their unique and remarkable artistry and scholarship seem to me entitled to the same sort of consideration, courtesy, and respect as the literary artist and scholar anywhere.

Once the material had been digitized, cataloged, and copyright cleared, MP4 tracks were cut from the archived WAV files according to the timings determined by the catalogers, and the individual items were published online with linked metadata. There are thousands of items now available on the Tobar an Dualchais/Kist o Riches website, though this as yet represents only a fraction of the material held in the School of Scottish Studies Archives. However, this selection allows access to material from anywhere in the world and provides a tremendous resource for scholars of oral traditions. It will encourage comparative research on oral and textual varieties of the various genres, enable international research on tales and customs, give voice and music to songs hitherto available only in print, allow linguists access to particular features of moribund dialects of Scots and Gaelic, and so forth. The uses are endless both in terms of international and comparative scholarship, and for more localized research into transmission, repertoires, and styles of music, songs, and storytelling of individual contributors or communities. Further material on all topics is available from the archive itself.

3 "Ownership" of folklore and oral tradition as well as notions of "collective" as opposed to individual origination are topics of much debate, particularly as concerns intellectual property rights. Hafstein (2004) suggests that, rather than dichotomize "communal" and "privatized" knowledge, the notion of origins/originality inherent in rights relating to intellectual property should focus on the act of creation which is always a social act involving transformation of previous knowledge, "communal origination through individual re-creation" (310). 


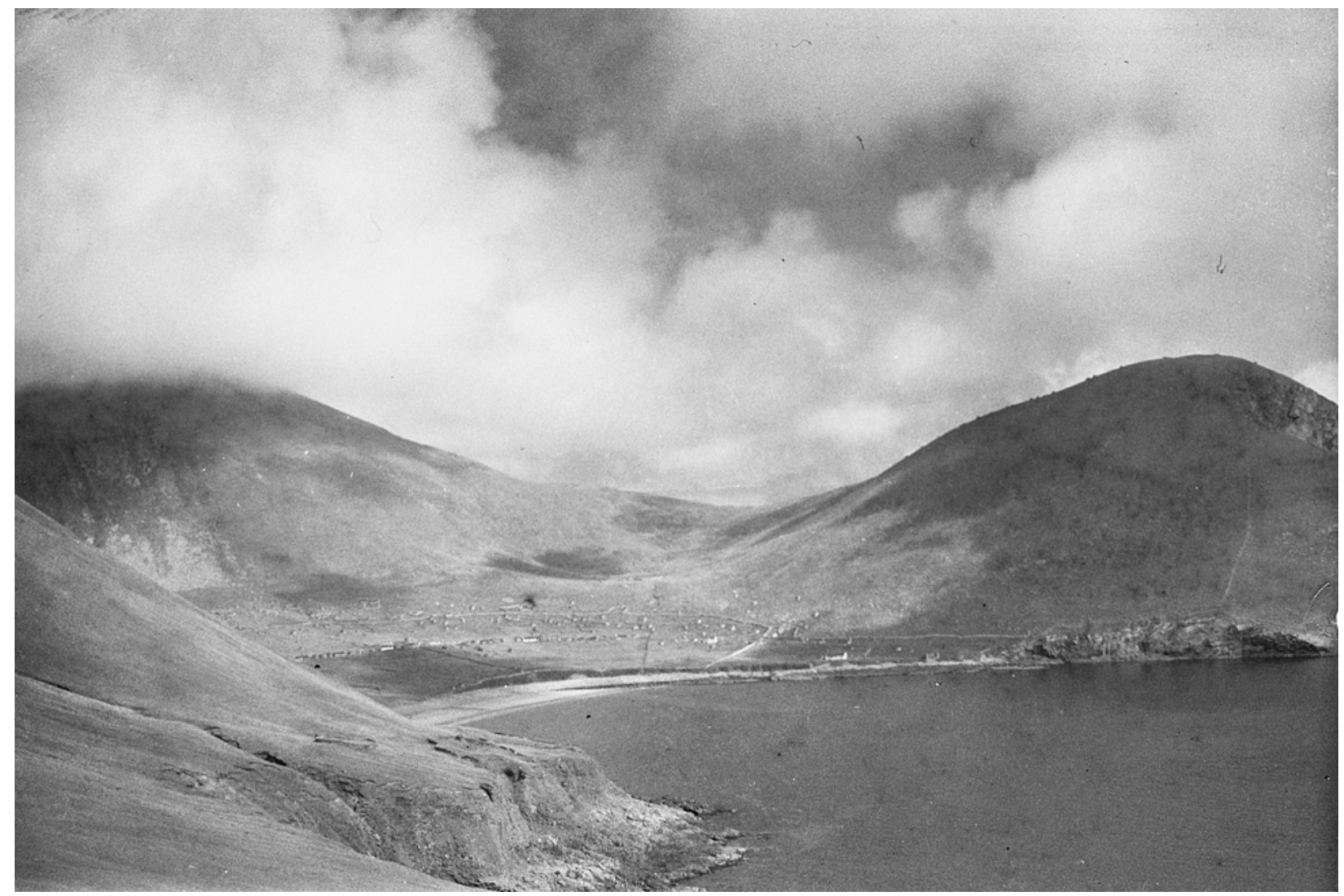

Image 3: St Kilda. Village Bay, Oiseabhal and Conachair. Photo by Robert Atkinson, 1938 (School of Scottish Studies Archives).

As an example of the kinds of material available on the website, I include a taster from St Kilda, a small archipelago located around forty miles off the Western Isles of Scotland. ${ }^{4} 2010$ marked the eightieth anniversary of its evacuation, undertaken at the request of its people, numbering only 36 by 1930, a population by then so small that there were not enough young, able-bodied men to sustain it. Various factors contributed to its decline, including a series of illnesses and accidents and the government's refusal to provide either a health or transport infrastructure despite being able to do so during the First World War, when there was a naval station on the island. Contact with servicemen had also enabled young people to find out more about life elsewhere and encouraged emigration.

Life on Hirte, the archipelago's largest island, was not so very different from the other Gaelic-speaking islands of the west. However, it is an island that has captured the romantic imagination. It is notable for its isolation due to notoriously precarious sea conditions and weather fronts that have made it difficult to reach and to anchor safely. During most of the nineteenth century there were just two official sailings a year. The only landing place is Village Bay. From there the island sweeps upwards until you are standing at the top of huge cliffs, home to a massive bird population — gannets, fulmar, shearwater, puffin, guillemot — in fact, the biggest gannetry in the world. The men were notable fowlers and spectacular cliff climbers - seabirds

\footnotetext{
${ }^{4}$ For further information on material relating to St Kilda, see Macaulay 2011.
} 
formed the main part of the diet and subsistence on the island, and they also provided a means of barter and, later, cash. Fulmar were harvested in August and the feathers were sold to pay the rent to the landlords, for many centuries the MacLeods. Their oil was used as fuel for the crusie lamps and to lubricate the wool for spinning and weaving the famous St Kilda tweed. Only Hirte was populated, but fowling trips were made to nearby Boreray, Stac Lì, and Stac an Armainn, the huge guano-covered rocks rising almost vertically out of the ocean.

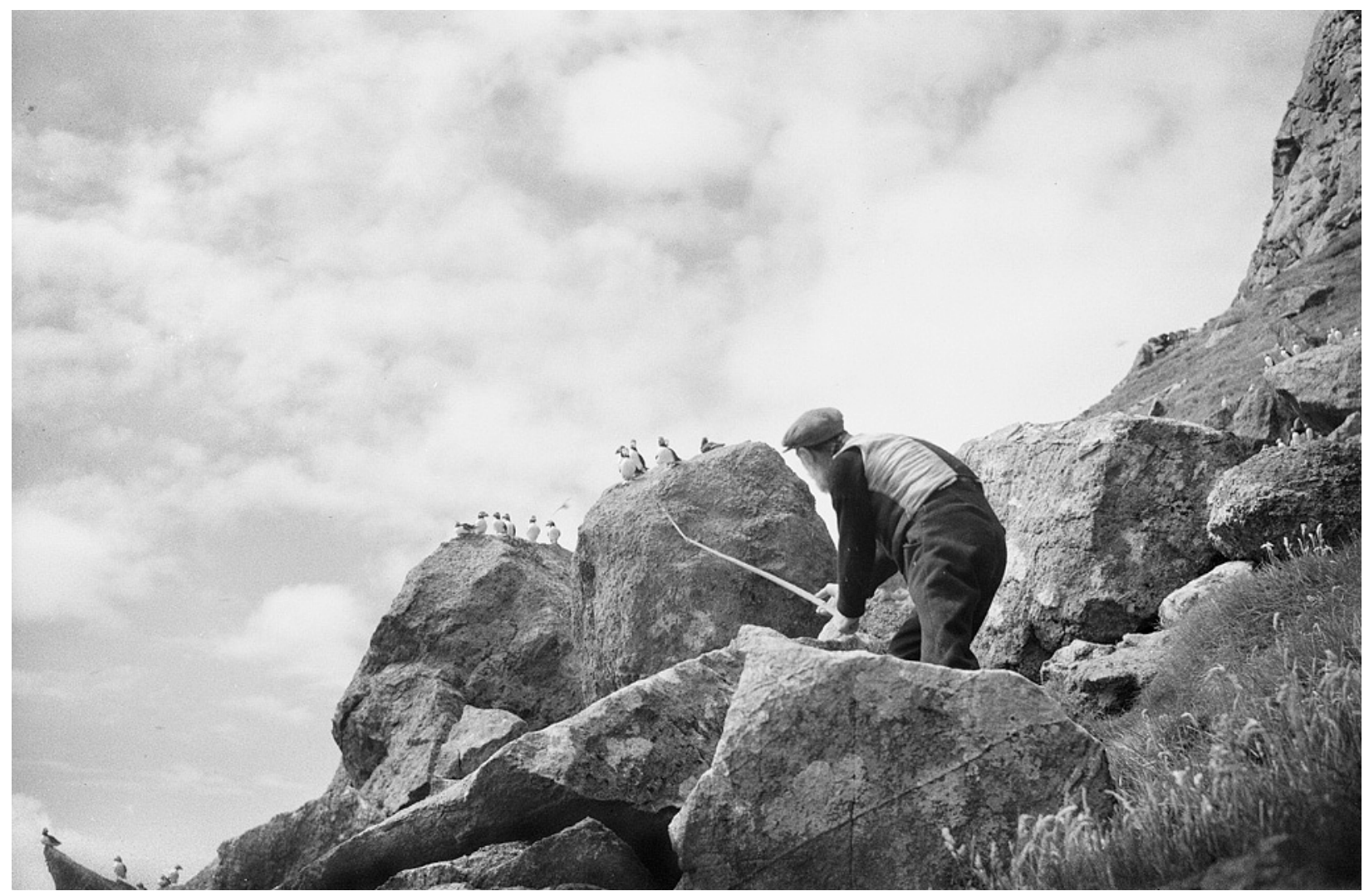

Image 4. Finlay MacQueen snaring puffins, Carn Mor, St Kilda. Photo by Robert Atkinson, 1938 (School of Scottish Studies Archives).

Life on the island was dominated by the necessity to work for survival and, apart from fowling, the islanders fished, kept sheep, and cultivated the small patches of arable land. As in the other Hebridean islands, work was managed communally. It was an oral culture with many proverbs and sayings (pertaining to work, the weather, and so forth), wit, songs, and oral literature. Gaelic was the language of the people - there was a distinct dialect for which there are now no speakers left.

St Kilda has long proven a source of interest among collectors. Martin Martin (1665? -1718), a Skyeman and Gaelic speaker, visited in 1697, and his account of his time there was among the first of a long series of historiographies of island life. During the nineteenth century, St Kilda became something of a tourist "Mecca," the subject of many myths and much speculation, and the volume of publications increased so much so that there are now some 700 texts, mainly by people who never spent a night on the island and did not understand the 
language. There are very few Gaelic publications and only a couple written by islanders themselves.

Often the St Kildan is portrayed as a "noble savage" (or sometimes a savage savage) and the communal way of life portrayed as a kind of Utopian ideal, rather than as a pragmatic solution to geographical circumstances. Religion plays a great part in the outsiders' accountsthe influence of a succession of Presbyterian missionaries, according to various writers, led to the death of fun, music, songs, and storytelling. We are fortunate, in the archive, to have recordings from nine of those who were born and grew up on the island. The recordings are valuable because they provide an "insider's" perspective and provide some evidence that the art of storytelling was alive and well during this time. The following tale is something of an archetype. Dùgan is Fearchar Mòr ("Dugan and Big Farquhar") was known and told by practically all of those that were interviewed, each of the versions having slight variations in style and content. Norman MacQueen tells the tale to fieldworker John MacInnes in 1961:5

Dùgan is Fearchar Mòr: bhiodh iad a' falbh 'na h-Eileanan Flannach a mharbhadh chaorach — a ghoid chaorach agus 'gan toir leotha Hirte. Agus co-dhiù, là bha seo, dh'fhalbh iad a mhullach na beinneadh, Dùgan is Fearchar. Agus bha teampull ann an t-Hirte fo'n talamh far am biodh daoine teicheadh ma thigeadh an nàmhaid. Agus bha an dorus cho caol air agus chan fhaigheadh sibh a staigh ann mara deidheadh sibh a staigh ann air an oir. Agus dh'fhalbh an dà bhodach a bha seo, là bha seo, mhullach na beinneadh agus thòisich iad ri eubhach à mullach na beinneadh gu robh na soitheachan-cogadh . . . cogadh a's a' Chaolas Bhoighreach agus a chuile duine aca dhol dh'an teampull. Well, dh'fhalbh na daoine bochd air fad dh'an teampull a bha seo agus 'se rinn mo liagh $[s i c]$ ach thòisich iad ri buain fraoch; bhuain iad boitean a [sic] fraoch a' fear agus thug iad leotha am boitean a' fear air an gualainn is thàinig iad dhachaigh.

Is bha na daoin a's an teampull. Ach bha rùm gu leòr gu h-ìseal a's an teampull. Agus nuair a thàinig iad a nuas a [?] cha do rinn iad càil ach chuir iad am boitean ris an dorus agus chuir iad maidse leis agus thac iad a chuile duine riamh bha 'san àite. Ach fhuair aon nighean — bha $\mathrm{i}$ còig bliadhna diag - fhuair ise mach a measg a' cheò a bha seo agus chaidh i ann an uamha dh'fhalach gus an dàinig am bàta. . . . Agus coma co-dhiù là bha seo an dèidh dhiu na daoine mharbhadh, chaidh iad a ghabhail ceum-Dùgan is Fearchar. Agus . . "A ghoistidh! a ghoistidh!," as an dala fear ris an fhear eile, "tha mi faotainn àileadh teine seo!" "Ho! isd amadain! Chan 'eil," as eisein, "ach teine dh'fhàg thu as do dheaghaidh." Agus dè bh'ann ach bha an nighean a theich bha i fo'n a' chreag a bha seo fòtha agus cha do rinn i càil ach a h-aodach a chuir ma mhullach na poiteadh a bh'aic air an teine le biadh fiach gun cumadh $i$ an ceò gun a dhol a suas. "Och," as eisein, "a ghoistidh, ghoistidh, 'se an teine a dh'fhàg sinn as ar n-deaghaidh."

Well, dh'fhalbh iad an uairsin is ghabh iad ceum agus là airne mhàireach thàinig a' soitheach a bha seo - soitheach a' bhàillidh. Agus bha nighean, bha i a's an toll a bha seo, cha dàinig i mach leis an eagal agus dh'fhan i a's an toll gos a robh am bàta beag gu bhith aig a' chidhe agus nuair a bha am bàta gun a bhith aig a' chidhe, thàinig i mach as an toll agus chaidh an dithis acasan a sìos a choinneachadh an eathar, 'eil thu faicinn? Agus nuair a mhothaich iad dh'an

5 Norman MacQueen recorded by John MacInnes, School of Scottish Studies Archives, SA1961.19.A1 (http://www.tobarandualchais.co.uk/en/fullrecord/79150/1). Transcription and translation by John MacInnes (1961:215-19). 
nighean, as an dala fear ris an fhear eile, "'S fhearr dhuinn falbh agus a marbhadh." Well, cha d'fhuair iad . . . cha d'fhuair iad an t-seansa . . . cha d'fhuair iad an t-seansa marbhadh. Chaidh iad ... leum na daoine mach as an eathar is fhuair iad greim air an nighean a bha seo agus dh'inns an nighean dhiu a' naidheachd.

Well, rugadh air an dala fear aca—rugadh air Fearchar agus chuireadh e Stac an Aramair a measg nan eòin agus chuireadh Dùgan a Shòaigh, an eilean eile tha an iar air Hirte, measg nan caorach agus a measg nan ian. Well, a' fear a chuir iad a Stac an Aramair, ghearr e as deaghaidh an eathair agus chaidh a bhàthadh — cha do thog iad idir e — ghearr e mach air a' mhuir is leig iad leis gun do bhàsaich e. Ach Dùgan, chaidh a chuir a Shòaigh agus bha e ann bliadhnachan beò; bhiodh e ' $g$ ithe nan caorach is ag ithe nan eòin. Than a h-asnaichean aige fhathasd ann a shiod: dh'fhiach mi fhèin na h-asnaichean 'na mo làimh.

\section{English Translation}

Dugan and Big Farquhar: they used to go to the Flannan Islands to kill sheep-to steal sheep and bring them back into St Kilda. Well, one day they went up to the top of the hill, Dugan and Farquhar. And there was a temple in St Kilda, underground, where people used to flee if an enemy came. The doorway was so narrow that you could not get in unless you entered sideways. And these two fellows went to the top of the hill one day and began to shout from the top of the hill that there were warships in the Kyle of Boreray and everyone to go to the temple. Well, all the poor people went to this temple and what did my bold lad(s) do but begin to cut heather; each of them cut a bundle of heather and carried his bundle on his shoulder and they came home.

The people were in the temple, but there was plenty of room down inside it. And when they (the two men) came ... they immediately placed the bundle against the doorway and they lit it with a match and they choked every single person in the place. But one girl managed - she was fifteen years of age - she managed to get out in the smoke there and she went to a cave to hide until the ship arrived. . . At any rate, one day after they had killed the people, they went out for a stroll—Dugan and Farquhar. And ... "My friend!" said one of them to the other, "I get the smell of fire here!" "Oh quiet, you fool! It is only the fire that you have left after you." What was it but the girl who escaped; she was underneath the rock below them and at once she placed her clothes over the top of the pot that she had on the fire with food in it, so as to keep the smoke from ascending. "Och my friend," said he, "it is the fire that we left after us."

Well, they went off then and they took a stroll and the following day the ship came - the factor's ship. And the girl, she was in the hole there; she did not come out through fear and she remained in the hole until the small boat was almost at the pier, and when the boat was almost at the pier she came out of the hole and the two men went down to meet the boat, do you see? When they observed the girl, one said to the other, "We had better go and kill her." Well, they did not get a chance to kill her. The men leapt out of the boat and they caught hold of the girl, and the girl told them the tale.

Well, one of them was seized-Farquhar was seized and put out on to Stac an Aramair among the birds, and Dugan was sent to Soay—on another island west of St Kilda—among the birds and among the sheep. The man whom they sent to Stac an Aramair, he jumped after the boat and was drowned: they did not pick him up-he jumped into the sea and they left him until he 
died. But Dugan, he was sent to Soay and he was there alive for years: he used to eat the sheep and the birds. His ribs are there still; I myself have handled the ribs.

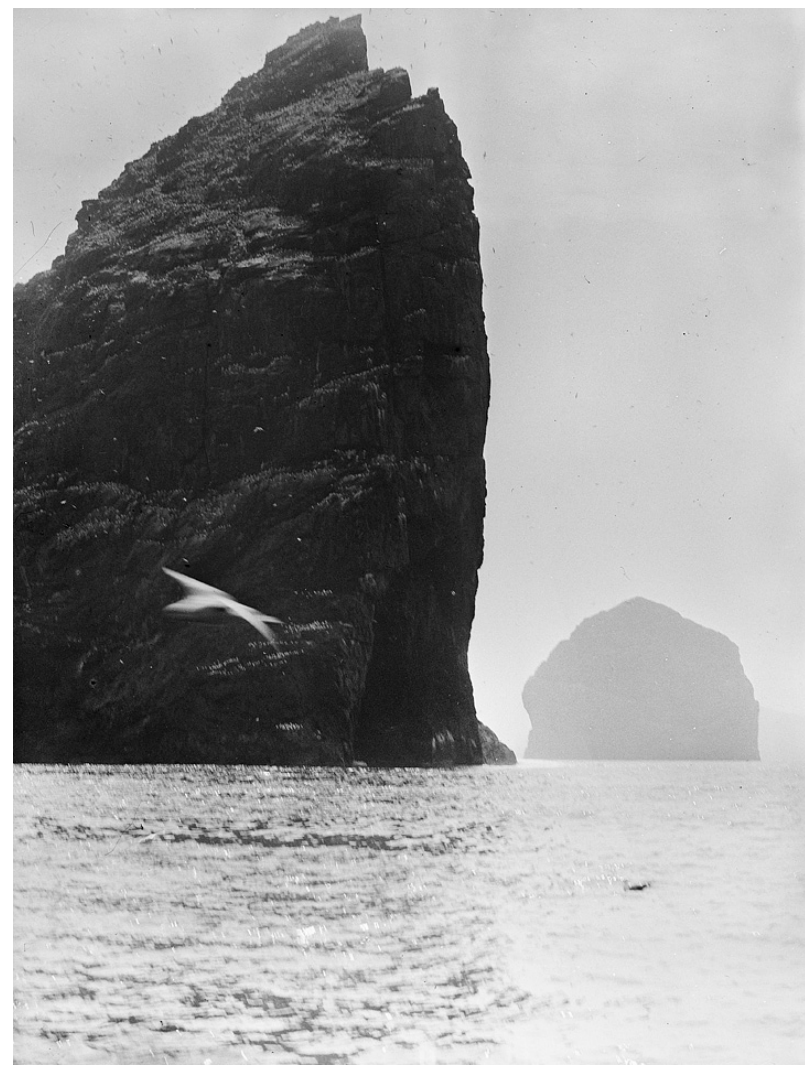

Image 5. St Kilda: Stac an Armainn. Photo by Robert Atkinson, 1947 (School of Scottish Studies Archives).

Donald MacQueen, uncle of Norman MacQueen, indicated that the teampull, or temple, referred to in the tale was on his own croft, though it is often now called the Fairy Cave by tourists. This historical legend is a fascinating one, partly because it was so wellknown among St Kildans. As well as those recorded for the archive, two earlier versions have been published (Maclean 1838, Thomas 1874). The theme of burning or asphyxiating people taking shelter in a church or cave is present in various historical clan tales in Scotland. In one notorious event, the Eigg Massacre of 1577, part of the MacLeodMacDonald clan feuds, the population hid in a cave when they saw MacLeod's galley coming, and they were murdered when a fire was set at the entrance. ${ }^{6}$ In some versions of this tale, too, there is one survivor. In fact, the theme of the solitary survivor is not uncommon in traditional tales.

The tale is of interest also in portraying the relationship between islanders and outsiders. In the version by Donald MacQueen, the two men are described as coming from the mainland and taking control of the island (MacInnes 1961). There are various historical accounts of pirates and even slave traders working in these waters. Islanders tended to run for cover after spotting a strange ship. This behavior is mentioned in the accounts of various visitors to St Kilda (Robson 2005) and happened as late as 1918, as recounted by Donald MacQueen himself discussing the arrival of a German U-boat in these waters, while being interviewed for the Gaelic Linguistic Survey of Scotland in 1951. ${ }^{7}$ The tale has many interlinking threads that shed light on the place, the people, and historical events.

This example is just one of a vast repertoire of tales, songs, rhymes, riddles, and so forth in both Gaelic and Scots that are now available online. Hearing the audio gives it an aesthetic and personal context that is hard to determine just from reading the printed version. While "rescue ethnology" may have been the subject of discourse, it has nevertheless enabled the

6 An example of this tale can be found on the Tobar an Dualchais/Kist o Riches website at http:// www.tobarandualchais.co.uk/en/fullrecord/45450/1.

${ }^{7}$ Donald MacQueen, School of Scottish Studies Archives, GLS44. The Gaelic Linguistic Survey is held in the School of Scottish Studies Archives, University of Edinburgh. 
preservation of historical material that would otherwise no longer exist. Through its program of collecting, the School of Scottish Studies has enabled the oral tradition, the voices of Scotland's people, to be held and valued by ensuing generations. It is somewhat ironic that while the massive changes of the twentieth century have contributed to the decline of the oral tradition, at the same time, these technological developments have enabled us to return songs, stories, and ways of being to the communities from which they came and, indeed, to make them accessible to emigrants from these communities in every part of the world.

University of Edinburgh

\section{References}

Aitken 1985

J. F. Campbell 1890

J. L. Campbell 1984

J. L. Campbell 1950

Carmichael 1900

Corbett et al. 2003

Hafstein 2004

Harman 1997

Kennedy-Fraser 1909-21

Macafee 2003
A. J. Aitken. "A History of Scots." In The Concise Scots Dictionary. Ed. by Mairi Robinson. Aberdeen: Aberdeen University Press. pp. ix-xvi.

John Francis Campbell. Popular Tales of the West Highlands. Vol. 1. London: Alexander Gardner Paisley.

John Lorne Campbell, ed. Highland Songs of the Forty-Five. Edinburgh: Scottish Academic Press/Scottish Gaelic Texts Society. ed. Gaelic Folksongs from the Isle of Barra. London: Linguaphone/ Institute for the Folklore Institute of Scotland.

Alexander Carmichael. Carmina Gadelica. Vol. 1. Edinburgh: Oliver and Boyd.

John Corbett, J. Derrick McClure, and Jane Stuart-Smith, eds. The Edinburgh Companion to Scots. Edinburgh: Edinburgh University Press.

Valdimar Tr. Hafstein. "The Politics of Origins: Collective Creation Revisited." The Journal of American Folklore, 117:300-15.

Mary Harman. An Island Called Hirte: A History and Culture of St Kilda to 1930. Isle of Skye: Maclean.

Marjory Kennedy-Fraser. Songs of the Hebrides. 3 vols. London: Boosey.

Caroline Macafee. "A History of Scots to 1700." In A Dictionary of the Older Scottish Tongue: Volume XII. Ed. by Margaret G. Dareau, Lorna Pike, and Harry D. Watson. Oxford: Oxford University Press. pp. xxix-clvii. 
Macaulay 2011

MacDonald 1972

MacInnes 1961

Maclean 1838

MacPherson 1765

Martin 1698

Robertson and Dilworth 2009

Robson 2005

Sanderson 1957

Shaw 1977

Thomas 1874

Trebitsch 2003
Cathlin Macaulay. "Voices from St Kilda in the School of Scottish Studies Archives." In Re-Writing St Kilda: New Views on Old Ideas. Ed. by Bob Chambers. Lewis: Islands Book Trust. pp. 35-63.

Donald A. MacDonald. "Collecting Oral Literature.” In Folklore and Folklife: An Introduction. Ed. by Richard Dorson. Chicago: The University of Chicago Press. pp. 407-30.

John MacInnes. “A Folktale from St Kilda.” Scottish Studies, 5:215-19.

Lachlan Maclean. Sketches on the Island of St Kilda. Glasgow: McPhun.

James MacPherson. The Works of Ossian. London. T. Becket and P. A. de Hondt.

Martin Martin. A Late Voyage to St Kilda. London: D. Brown and T. Goodwin.

Sylvia Robertson and Tony Dilworth, trans. and eds. Tales from Highland Perthshire Collected by Lady Evelyn Stewart Murray. Glasgow: Scottish Gaelic Texts Society.

Michael Robson. St Kilda: Church, Visitors and "Natives." Isle of Lewis: Islands Book Trust.

Stewart Sanderson. "The Work of the School of Scottish Studies." Scottish Studies, 1:3-13.

Margaret Fay Shaw. Folksongs and Folklore of South Uist. Oxford: Oxford University Press.

F. W. L. Thomas. "Letter from St Kilda by Miss Anne Kennedy, Communicated with Notes by Captain F. W. L. Thomas, RN FSA, Scot." Proceedings of the Society of Antiquaries of Scotland, 10:702-11.

Rudolf Trebitsch. The Collections of Rudolf Trebitsch; Celtic Recordings 1907-09. Austria: Österreichischen Akademie der Wissenschaften. 
Oral Tradition, 27/1 (2012): 187-230

\title{
"Our Grandparents Used to Say That We Are Certainly Ancient People, We Come From the Chullpas": The Bolivian Chipayas' Mythistory
}

\author{
Sabine Dedenbach-Salazar Sáenz
}

\section{Introduction ${ }^{1}$}

In this paper I will study the story ${ }^{2}$ that the Bolivian highland Chipayas tell about their origin and past. This oral tradition is closely related to the present. Not only does it explain and justify why they live where they do and how they do, but it also explains their often tense relationship with their immediate neighbors, the Aymaras. In the story, mythical and historical discourse are fused in order to construct their ethnic identity. Before examining the narrative in detail, it is necessary to discuss briefly the two theoretical concepts that underlie my analysis: ethnic identity and mythistory.

\section{Ethnic Identity}

The concept of ethnic identity is a construct that a sociocultural group creates to signal its self-definition, both for its own members as well as for outsiders. This understanding of identity, which is not static but undergoes changes, helps the group members shape and express perceptions of their own group and relationships with other groups. These perceptions can reflect

${ }^{1}$ An earlier version of this article was presented at the international conference on "Reading After Empire: Local, Global, and Diaspora Audiences" (University of Stirling, 3-5 September 2008). I would like to thank my colleagues Lindsey Crickmay and María Susana Cipolletti for their careful reading of the essay and for their suggestions. The data presented and discussed here were collected during fieldwork carried out in 2002, 2005, and 2006 in a project to describe and document the Chipaya language as part of the Documentation of Endangered Languages program, funded by the Volkswagen Foundation (see http://www.mpi.nl/DOBES). I wish to thank our Chipaya consultants for their patient and informed cooperation, particularly our main consultant, who not only helped with the transcription and translation, but also discussed grammatical, textual, and cultural topics with us. Due to the extremely difficult and tense situation within the village, the consultants expressed the wish to remain anonymous (this difficult situation was first described by Alfred Métraux [1931:127], and little has changed since then).

2 I use "story" and "narrative" interchangeably here. In Chipaya, the concept of story (kintu, from Spanish cuento) includes any kind of story, including animal stories (which normally carry a moral and are said to have happened in ancient times [pers. comm.]). However, I differentiate mythistory as a particular type of narrative limited to explanatory stories about the group's past, in this case their origin and development as a community (see below). 
the pride of belonging to a group and/or they can be a response to prejudice and discrimination, and in many cases both factors reinforce one another. The boundaries that result from this groupdefining process can be physical (reflected, for example, in the competition over natural resources or access to markets) as well as conceptual (manifest, for example, in a certain interpretation of the past or a tradition, be it invented or not). Because social and ethnic groups always interact with other groups, this construct affects and changes a group's internal perceptions of identity and at the same time influences how a group shapes its image of other, especially neighboring, groups. This construct also contributes to the image that these neighboring groups form regarding the group in question. ${ }^{3}$

\section{Mythistory}

Both history ${ }^{4}$ and myth ${ }^{5}$ are normally verbal explanations of the past. They are used to construct socially and culturally relevant past events, are often related to public rituals, and are told by a narrator who tends to be a recognized representative of the group. Both history and myth claim to be authoritative and legitimate, and both highlight a continuing relevance of the past to the present and future. However, one of the most important tasks of myth is to interpret sociocultural values and give them meaning and importance in contemporary life. While history may be seen similarly, it is not typically used as a learning experience, although it may be intended as such.

The most distinctive differences, which have largely determined our basic conceptual separation of myth and history, are medium and author. Myth is usually transmitted orally (and can be supported by visual means, such as rock shapes or paintings and/or rituals that enact the myth). However, when we analyze it, it has almost always been transferred to and transformed into writing, most often by an outsider. History tends to be transmitted in writing, but it is

${ }^{3}$ This definition has been inspired mainly by Barth 1969 and Keefe 1992.

${ }^{4}$ In this article I use "history" interchangeably with "historiography," but not with "the past." History is a narrative, ordered according to certain thematic and/or theoretical criteria, that aims to explain events of the past in a meaningful and coherent way. The function of history-writing and publication is not only to provide a certain society with a meaning of its past, but to serve an ideological agenda as well. This can be the interpretation of the past as factual events or reality (reconstructionism), or it can be the intention to recognize and show that no absolute knowledge of the past is possible (relativism). In any case, history is always a narrative; it can never represent the past in a universally acceptable way. It often reflects concrete political, religious, or economic agendas of the group the historian belongs to, or it may oppose these agendas. Therefore, history is not objective or neutral. (I have found Burke 1991 and Munslow 1997 particularly useful for this discussion.)

${ }^{5}$ Myth is an equally complex concept that is mainly used by anthropologists who study other peoples' past and traditions, normally with respect to ethnic groups who do not use writing. Here I follow the comprehensive definition given by William Bascom (1984:9) (without any of the evaluative and frequently negative connotations historians, sociologists, and psychologists often imply): "Myths are prose narratives which, in the society in which they are told, are considered to be truthful accounts of what happened in the remote past. They are accepted on faith, they are taught to be believed, and they can be cited as authority. . . . Myths are the embodiment of dogma, they are usually sacred, and they are often associated with theology and ritual. Their main characters are not usually human beings, but they often have human attributes; they are animals, deities, or culture heroes, whose actions are set in an earlier world, when the earth was different from what it is today, or in another world such as the sky or underworld. Myths account for the origin of the world, of mankind, of death, or for characteristics of birds, animals, geographical features, and the phenomena of nature." 
frequently communicated through oral or visual means (such as exhibitions or television), and this was even more the case in the past, when paintings and oral discourse were the only means of conveying "history" to an illiterate audience. It is also often enacted in public ceremonies, for example in commemoration. In this sense there is no clear boundary between a "fixed" written transmission and a "fluid" oral transmission.

The other major difference is authorship. Myth has no identifiable authors; it is conceived of as a narrative that belongs to and is produced by the community, although, of course, it is practically impossible to study how myth develops over time in its own environment, without "outside" interference; therefore, little is known as to the function and role of the narrator and the audience in the shaping and reshaping of the text. ${ }^{6}$ History, on the contrary, normally has an individual as author, but once we start asking about the composition and editing process of a book, including the selection of sources as well as changes due to invited critique, the seemingly clearly defined authorship becomes elusive.

As I hope to have shown, the concepts of myth and history are not as far apart from each other as one might think. Therefore, the fused concept of mythistory ${ }^{7}$ seems to be a legitimate and adequate combination to describe socially relevant narratives, especially in the discourse of the indigenous population in contemporary post-colonial societies. Since the colonial period, with its indoctrination and teaching of European values and interpretations of the world, both myth and history have informed and modified indigenous concepts of how to understand and interpret the past. We also have to consider that European "history" was always intertwined with religious beliefs and interpretations and therefore must have been more accessible to those peoples who did not normally separate the "secular" from the "spiritual." Mythistory can be defined in the following way: it is (most often) a narrative construction of past events that are seen as relevant or even crucial for the creation, explanation, shaping, and maintenance of an ethnic group's identity and social cohesion. It is considered to be true, authoritative, and legitimizing and can/must therefore be modified and adapted to new circumstances. ${ }^{8}$

The origin story of the Bolivian Chipayas shows how both concepts, myth and history, have shaped the contemporary construction of the Chipayas' past, and that this mythistory is an important instrument for explaining and legitimizing their ethnic identity, in concrete as well as symbolic terms. The origin mythistory and early folk history ${ }^{9}$ as told by the Chipayas themselves includes the following major themes: the ancient ancestors called chullpas and the reasons why

6 Some discussion is found in the framework of formulaic theory and oral theory as well as in oralityliteracy debates (see, for example, Finnegan 1992, also Foley 2002).

7 This term, which goes back to Francis Cornford's 1907 Thucydides Mythistoricus (quoted in Mali 2003:19), has since been used by historians (for example, McNeill 1986 and Mali 2003), although with a different interpretation from mine.

${ }^{8}$ Arnold (1993:49-55) emphasizes the importance of including the narrators' and communities' own views in the interpretation of their past. I would like to add to Arnold's suggestion that it is not enough to "report" on the views expressed by consultants: the anthropologist's analysis should also reflect the complex process of interaction and expectations between the community members and fieldworkers. The present study is basically limited to a textual analysis but tries to take these observations into account where possible.

9 As defined by Hudson (1966:54), "in a folk history we attempt to find what people in another society believe 'really happened,' as judged by their sense of credibility and relevance." 
the Chipayas are the most ancient people in the area, if not in the Andes; their migratory movements in the larger area where they live now, with explanation of the modern territorial limitations as well as neighborhood conflicts; and the particular surnames as a result of contacts with Aymara neighbors and Christian religion. By drawing on different kinds of constructions of the past, European as well as indigenous in form and content, the three themes are closely interrelated and situate the Chipayas in space and time. They also serve to explain their ethnic identity and legitimize territorial claims.

\section{The Uru-Chipayas}

As first documented in sixteenth-century Spanish sources, the people called Urus or Uruquillas by the colonial writers lived around the great lakes of what is today Peru and Bolivia: Lake Titicaca, Lake Poopó, and Lake Coipasa, on the rivers connecting them and on the socalled floating islands of Lake Titicaca. These people call themselves "water people." 10

In the past, this population was different from the surrounding herding and peasant Aymara- and Puquina-speaking groups because Uru subsistence was based on fishing and birdhunting, and because they spoke their own language. With Inca and later Spanish colonial resettlements the Urus lost much of their lifestyle, intermarried with the surrounding Aymara population, and by the beginning of the twentieth century had become reduced to small groups. The best known of these are the Urus who live on the "floating islands" of Lake Titicaca; they now speak Aymara and make their living mostly through tourism. The Urus of Irohito at the southern end of Lake Titicaca and the Muratos on the shores and islands of Lake Poopó have also lost their language. However, in their oral traditions, their clothing, and certain elements of their material culture the Urus maintain common cultural features.

The mythistory studied here is that of the village of Santa Ana de Chipaya (Illustration 1, Maps 1-3). On the Altiplano at a 3,670-meter altitude, efficient agriculture and animal breeding are limited by extreme day-night temperature variations, salty soil (Illustration 2), and inundations during the wet season (November to March). Therefore, many Chipayas migrate to work in Chile or eastern Bolivia; however, there is still a tendency to return to the community. Important features of self-identification are fishing and bird-hunting (Illustration 3) in and by the river Lauca that flows through their territory; round houses; a particular type of clothes, woven by the wearers (Illustration 4); and the Chipaya language. When asked what is most typical of their culture, they always mention these features.

However, bird-hunting and fishing are mainly carried out in the wet season to supplement a diet mostly composed of quinoa ${ }^{11}$ and potato. Sheep, pigs, and llamas are bred and kept to supply wool and meat and may in a good season provide a modest income. Nowadays no one in the village lives in a round house and traditional clothing is only worn on special occasions. The

10 See Map 1. (Maps and illustrations are located at the end of this essay.) For a state of research and bibliography, see Dedenbach-Salazar Sáenz 2007a.

${ }^{11}$ Quinoa (Chenopodium quinoa) is a native Andean cultivated grain that grows at high altitudes (National Research Council 1989:148-68). 
only particularity the Chipayas have maintained is their language, which is spoken by almost all of the approximately 1,800 community members. The language is not related to any other language of the Andes; it is still fully functional, although increasingly endangered by radio and television, schooling in Spanish, and migration. Another feature familiar to everyone and one that seems little changed over the past century (ethnographic information began to be collected at the end of the nineteenth century) is the mythistory of their origin and remote past, which goes back to ancient times but also relates to their present-day lives.

\section{Chipaya Mythistory}

The Chipayas' mythistory consists of several episodes and has been published, among others, by Alfred Métraux in the 1930s (see Appendix, Text 1) and by Nathan Wachtel (1990). ${ }^{12}$ A detailed version in Spanish, written by Fernando O. Martín Quispe, a youth from Chipaya, in his notebook was published in 1955. The late Porterie Gutiérrez' notebooks (and a number of sound files and transcriptions) that are available on the Internet also contain chullpa stories, among them several mythistories (see Porterie Collection 1982-85). Two texts collected by the DOBES team also narrate the story (Appendix, Texts 2 and 3 ).

During a workshop in Chipaya in 2002, all participants, mostly young men, knew this story and could narrate it themselves. Thus the interpretation of Chipaya mythistory can be said to have been relatively stable throughout a period of at least seventy years. Our consultants said that this mythistory is narrated like any other story - for example, when going out to the pastures or passing long days and nights there away from the village.

The story as a whole comprises three distinguishable episodes: the chullpa ancestors, the founding of the Chipaya, and the receiving of surnames. ${ }^{13}$ Drawing together the individual texts, Table 1 gives "the whole story" (this and the chronology were confirmed by one of our consultants and are reflected in the Porterie Collection texts).

12 Wachtel (1990:216-22), who carried out important ethnographic and ethnohistorical research on Chipaya culture, renders the story in French, without citing consultants or any details of the context in which it was told to him or how he obtained it.

${ }^{13}$ Three versions of the story are presented in the Appendix, and I will refer to some passages of the stories of F. Quispe (1955), M. Quispe (1984, 1985), E. Quispe (1985), and José Condori (1982). 


\section{Table 1: The Narrative-Chipaya Mythistory}

\begin{tabular}{|c|c|c|}
\hline Chronology & $\begin{array}{l}\text { Chipaya mythistory } \\
\text { (For the texts see Appendix) } \\
\text { Text 1: }<\mathrm{M}>\quad \text { Métraux 1935b } \\
\text { Text 2: }<\mathrm{C} 1>\quad \text { Consultant 1, 2002 } \\
\text { Text 3: }<\text { C2> Consultant 2, } 2005\end{array}$ & $\begin{array}{l}\text { Chipaya interpretation } \\
\text { Construction and justification of their } \\
\text { ethnic identity and interethnic } \\
\text { relationships through their mythistory } \\
\text { (sources: field observations and } \\
\text { Chipaya consultants). }\end{array}$ \\
\hline $\begin{array}{l}\text { First generation: } \\
\text { chullpa ancestors } \\
\text { - sensitive to the sun } \\
\text { - agriculturalists }\end{array}$ & $\begin{array}{l}\text { The ancient chullpas lived by the light of } \\
\text { the moon. They built their houses with the } \\
\text { entrance towards the east so that the sun, } \\
\text { which used to rise from the west, wouldn't } \\
\text { burn them. They cultivated quinoa and } \\
\text { cañihua. }{ }^{14}\end{array}$ & $\begin{array}{l}\text { Today they are mainly agriculturalists } \\
\text { and herders. }\end{array}$ \\
\hline $\begin{array}{l}\text { First key event: } \\
\text { natural catastrophe }\end{array}$ & $\begin{array}{l}\text { One day the sun rose in the east and burned } \\
\text { most of them }<\mathrm{M}: 1 ; \mathrm{C} 2: 3>\text {. }\end{array}$ & \\
\hline $\begin{array}{l}\text { Second generation: } \\
\text { Chipayas } \\
\text { - herders of wild animals }\end{array}$ & $\begin{array}{l}\text { One couple saved itself and started living } \\
\text { in the water and used to come out only at } \\
\text { night. They herded vicuñas }{ }^{15}<\mathrm{M}: 1 ; \mathrm{C} 1: 3>\text {. }\end{array}$ & $\begin{array}{l}\text { The Chipayas consider themselves to } \\
\text { be the only descendants of the most } \\
\text { ancient people of the region, the } \\
\text { chullpas. }\end{array}$ \\
\hline $\begin{array}{l}\text { - fishers, hunters, gatherers } \\
\text { - resettlement } \\
\text { - contact with Aymaras of } \\
\text { Capilla Perdida area }\end{array}$ & $\begin{array}{l}\text { At that time they lived in Capilla Perdida } \\
\text { (Lost Chapel), a different place from the } \\
\text { modern village, and came to the lake that } \\
\text { was close to where the village of Chipaya } \\
\text { is now, in order to fish, hunt birds, and } \\
\text { collect eggs }<\mathrm{C} 1: 1 ; \mathrm{C} 2: 2>\text {. } \\
\text { Then they settled near the lake in order to } \\
\text { make hunting and fishing easier, but } \\
\text { thereby gave up their rights to Capilla } \\
\text { Perdida, which the Aymaras then took over } \\
<\mathrm{C} 1: 2>\text {. }\end{array}$ & $\begin{array}{l}\text { They are limited to a small village } \\
\text { between the hills in the north and the } \\
\text { (now reduced) lake in the south (see } \\
<\mathrm{C} 2: 2>\text { and Maps } 2 \text { and } 3 \text { ). }{ }^{16}\end{array}$ \\
\hline
\end{tabular}

${ }^{14}$ Cañihua (also cañahua, cañahui, Chenopodium pallidicaule) is a native Andean cultivated grain that grows at high altitudes (National Research Council 1989:128-37). M. Quispe (1985:1) states explicitly that the chullpas were not agriculturalists, whereas José Condori (1982:2, Porterie's transcription of the Chipaya text) says that there were no fields after the Judgment.

15 Vicuñas are wild animals, normally hunted in order to be shorn and then set free again (they are of the same family as llamas and alpacas [camelids], which are the domesticated variants). Our consultant affirmed that the vicuñas were the domesticated animals of the chullpas (and in Quechua traditions only the powerful mountain spirits "herd" vicuñas; see B. Condori and Gow 1976: "Los animales del Ausangate"). This and the fact that the Chipayas claim to have cultivated important Andean food plants in the distant past emphasize their self-image: in ancient times, when everything was different, they were powerful and skilled, but these capacities were lost in the process of colonization.

${ }^{16}$ It is important to note that the landscape in the Chipaya region has never been very stable. The lakes have changed their location, and so have the rivers and sand-dunes (Wachtel 1990:288-95, 302-20, 342). The earliest mention of the village is made in a document dating from 1575/76 (Libro de tasas 1575-91). 


\begin{tabular}{|c|c|c|}
\hline $\begin{array}{l}\text { - contact with Aymaras of } \\
\text { Huachacalla } \\
\text { - herders }\end{array}$ & $\begin{array}{l}\text { At night they went to Sabaya, a } \\
\text { neighboring old Aymara village, to help } \\
\text { build the bell-tower }<\mathrm{C} 1: 3 ; \mathrm{C} 2: 2>\text {; } \\
\text { Illustration } 7 \text {. }\end{array}$ & $\begin{array}{l}\text { The Chipayas say that they have tense } \\
\text { relationships with the neighboring } \\
\text { Aymaras; for example, they have to } \\
\text { pay too much for the traditional plant } \\
\text { used for thatching their houses; this is } \\
\text { why they use corrugated iron. There } \\
\text { are quarrels and fights over land rights. } \\
\text { But there are Aymaras who get married } \\
\text { to Chipayas; Chipayas live in Aymara } \\
\text { villages (information from an Aymara } \\
\text { woman in Huachacalla; information } \\
\text { from Chipayas). }\end{array}$ \\
\hline $\begin{array}{l}\text { Second key event: } \\
\text { Christianization, learning } \\
\text { Aymara = "civilization" }\end{array}$ & $\begin{array}{l}\text { They were discovered and captured. First } \\
\text { they could not make themselves } \\
\text { understood because they did not speak } \\
\text { Aymara. A Christian priest gave them their } \\
\text { surnames that are folk-etymologically } \\
\text { explained as Chipaya }<\text { M:2; C1:3; } 22: 2>\text {. }\end{array}$ & $\begin{array}{l}\text { The Chipayas consider their surnames, } \\
\text { given to them by a Christian priest (in } \\
\text { colonial times), as typically Chipaya. } \\
\text { In the explanation provided, the names } \\
\text { derive from Aymara/Andean words } \\
\text { (but etymologically not all of them do } \\
\text { so; see Table 3). }\end{array}$ \\
\hline
\end{tabular}

\section{Analyzing Chipaya Mythistory: Chullpas, Access to Land, and Names}

\section{The Chullpa Ancestors}

With respect to the past, the Andean peoples ${ }^{17}$ do not believe in a fixed point of origin of the world; rather, there has always been something in existence, but key events, mostly in the form of catastrophes, have produced generations of human beings who have come and gone (this belief can be found in early chronicles and still today, partly infused by Christian concepts). ${ }^{18} \mathrm{~A}$ common view of the past in the Andes is that of successive generations of ancestors, the ñwpa,

17 The highland people(s) of the Andes have many cultural features in common (this is often called lo andino), based on the particular ecological conditions they live in and their long history of mutual contact and interaction. The largest groups are those that speak Quechua (mainly in Ecuador, Peru, and Bolivia, c. 9 million speakers) and Aymara (mainly in Bolivia and Peru, c. 2 million speakers), whereas there are only c. 1,800 Chipaya speakers left. In terms of many cultural practices Quechua, Aymara, and Chipaya people(s) are not easy to delimit from each other. The clearest differentiation is through language because Quechua, Aymara, and Chipaya can be defined as distinct languages. Quechua and Aymara are typologically similar and have many words in common, but because the oldest records reach back only to the sixteenth century, it is impossible to trace the route loanwords may have taken or whether there was an ancient common Andean stock (cf. Torero 2002). Chipaya is typologically different from the other two and its vocabulary differs as well, although it has taken over a substantial number of Aymara words and a few, but frequently used Quechua words. Obviously all three languages have been subjected to considerable influence by Spanish, and so have the people(s) by Spanish/European culture. It is therefore not always possible to assign a certain element to any particular one of these languages/cultures, as is the case, for example, with the surnames (see Table 3 below). Therefore I use the word "Andean" when I refer to more than one of the mentioned groups, their languages, or practices.

18 For example, the chronicler Juan de Betanzos (informed by Inca consultants) starts his account about the beginnings of the world by stating that it is said that in ancient times that the land and provinces of Peru were dark and that there was no light (Betanzos 1987 [c. 1551], primera parte, cap. I, p. 11). Creation is not conceived of as making the world and humankind from nothing, but rather as bringing order into the world (cf. Marzal 1996:85). 
machu (Quechua "ancestor"), or gentiles (Spanish “ancestor," implying "pagan”) (Urbano 1980:117-19). Narratives tell us that there were ancestors who lived only by the light of the moon, and with the arrival of the sun (often equated with the Incas) they perished. In other versions of the narrative some people escaped and went to live underwater or in springs and have become malignant spirits. ${ }^{19}$ Yet another Quechua story tells that some persons escaped from being burned by the sun and went to the yungas (warm valleys of the eastern Andean slopes). Similarly, the Aymaras who are the Chipayas' direct neighbors talk of ancestors called chullpas, who were an ancient generation that perished when the sun rose first. The Aymaras themselves are a different people. This is reflected in the story of "Jesus Christ-Tatala and the SupayChullpas," told by the Aymaras from K'ulta (Bolivia). After fights between Tatala and the chullpas (Dillon and Abercrombie 1988:56),

\begin{abstract}
Tatala rises into the sky as the sun from the east, and the Chullpas die in their houses, burned and dried up by the heat. To this day, one can see their remains, and the sun, Tata Awatiri, continues to travel across the sky. Some of the Chullpas, however, managed to escape, by diving under the water of Lake Poopo [sic]. These became the present day Chullpa people [in this case the Urus of Lake Poopó, also called Muratos, SD]. ${ }^{20}$
\end{abstract}

While the origin stories vary among Quechuas and Aymaras, the chullpas still have a certain influence on them since they are related to the architectural remains of ancient graves called chullpas; coming into contact with them may have a negative impact: they can cause illness and death. ${ }^{21}$ The present generation of the Quechuas and Aymaras is a new post-machu/ chullpa generation that came into existence with the appearance of the sun ${ }^{22}$ and replaced (in the literal sense) a dark past: an uncivilized, wild world was superseded by civilization, represented most clearly through the domestication of plants and the introduction of agriculture as well as

19 See Núñez del Prado Béjar 1970:66, Marzal 1971:67-69, and Urbano 1993. For Quechua narratives, see Núñez del Prado Béjar 1970:63-67; B. Condori and Gow 1976: “Gentil inkamanta," “Gentil inka”); Urbano 1980 and 1993; and a variation in Phuturi Suni 1997:246-47.

20 Harry Tschopik (1951:202), for the Titicaca area, mentions the chullpas as "houses of the gentiles," which the Aymaras believe "to be the remains of the dwellings of the ancient inhabitants of the region before the coming of the Aymara." Jemio Gonzales (1993:112-13) mentions two Aymara stories: "Dark Time" and "The Chullpas," but she does not give their texts.

${ }^{21}$ For the impact chullpas can still have today, see, for example, the story "La gente chullpa" (in Albó and Layme 1992:54-57, Dillon and Abercrombie 1988:59-60, and Platt 2002:passim).

22 It is possible that in these traditions we find traces of the importance of the sun as deity, which was promoted by the Incas as their principal god but lost importance as soon as the Inca hierarchy and order were destroyed by the Spaniards in the sixteenth century. 
Christianization. Thus the time of the machu/chullpa is conceived of as an era prior to the Quechua and Aymara, who are the descendants of a different people and generation. ${ }^{23}$

The Chipayas, on the other hand, narrate a similar and yet substantially different story of their origin. They see the chullpas as their own ancestors, whereas - as the above mentioned Quechua and Aymara narratives show - the Quechuas and Aymaras do not see themselves as descendants of the first generation (see Table 2 below). But chullpa is the name of the first generations of Chipayas (Text $3,<\mathrm{C} 2: 3>$ ):

[Afraid of the Sun, which they believed to rise from the West,] they built the houses all oriented towards the East . . . but the sun never rose from the West. From the East rose the sun! The sun rays entered through the door. Then those who were on the hill burned. Thus the sun had risen with heat. Everything must have got burned. There wouldn’t have been any harvest or any life. Afterwards some of them died from hunger, having eaten wild straw, having eaten soft straw, being sad. Of those who were close to the lake, some of them, very few, would have saved themselves. Then afterwards we came [as descendants of those who survived]. There are also our forefathers, grandparents [left]: nowadays the houses of the chullpas are [still] on the hills in this area. Those forefathers, our grandparents, they died because, living higher up, they could not get to the water. ${ }^{24}$

In the region that coincides roughly with that of the ancient and modern Uru-Chipayas, remains of graves are found, "circular, square or rectangular buildings of stone or adobe" (Isbell 1997:163), many of which contain skeletons (Isbell 1997, ch. 5; see Illustrations 5 and 6 in the Appendix). These buildings are called chullpas. The Chipayas claim that these are the houses of their chullpa ancestors (see Text 3,<C2:3>).

23 Sixteenth-century chroniclers of the Andes give a very similar idea of what primeval times were like: darkness is the most distinctive feature (Betanzos 1987 [c. 1551], primera parte, cap. I:11-12; Cieza de León 1985 [1550s], cap. III:3-5; cf. Dedenbach-Salazar Sáenz 1994). Based on the analysis of colonial sources and other, secondary evidence, Bouysse-Cassagne and Harris (1987:19-28) conclude that the Urus, like the Aymaras' ancestors, were related to an era of darkness and wild(er)ness. We can therefore assume that modern Andean ideas of the beginning of the world have their origins in their own cultural roots. However, the Bible starts in the same way: light is the first thing created by God after having made the earth (The New Jerusalem Bible, Genesis 1:3). The difference compared with Christianity is mainly that Andean "origin" stories — as mentioned above - do not really start with an origin from nothing, there is no creator god in the biblical sense, and the generations that follow each other after each change or catastrophe are fundamentally different from each other (cf. Urbano 1980:113), unlike the Christians for whom, in the Bible, care is taken always to connect them to the one original pair of human beings through genealogical descent. In the Andes, on the other hand, the past generations can have influence on the present ones because they are conceived of as somehow still alive and present (which in turn has to do with the Andean concept that everything can change shape but hardly ever disappears completely) (cf. B. Condori and Gow 1976:20). In this sense, the Chipaya version of themselves being the descendants of the first human beings is quite similar to the biblical device to tie the important persons to an "original" line of descent.

${ }^{24}$ M. Quispe (1985:1) says that "the chullpas lived with another sun" (“los chullpas vivían con otro sol”). 
Table 2: Andean Eras

\begin{tabular}{|c|c|c|}
\hline Era & Quechuas/Aymaras & Chipayas $^{25}$ \\
\hline Moon & $\begin{array}{l}\text { generation } 1 \text { (= chullpa, machu, } \\
\text { gentiles) }\end{array}$ & generation $1(=$ chullpa $)$ \\
\hline Sun & $\begin{array}{l}\text { generation } 1 \text { perishes or goes to live } \\
\text { underwater or in the warm valleys- } \\
\text { new generation } 2 \text { (= Inca) comes, } \\
\text { related to the appearance of the sun: } \\
\text { rupture }\end{array}$ & $\begin{array}{l}\text { almost all of generation } 1 \text { die, } \\
\text { BUT } \\
\text { Chipayas survive by moonlight: } \\
\text { continuity }\end{array}$ \\
\hline Spanish $=$ Christians & (Jesus Christ-Tatala) & $\begin{array}{l}\text { and later become Christians (and } \\
\text { implicitly able to live like them) }\end{array}$ \\
\hline Present & $\begin{array}{l}\text { Quechuas/Aymaras < sun: } \\
\text { Generation } 2 \neq 1\end{array}$ & $\begin{array}{l}\text { Chipayas }<\text { chullpa: } \\
\text { Generation } 2=1\end{array}$ \\
\hline
\end{tabular}

From the colonial European perspective the Uru-Chipayas - being fishers and birdhunters - were not of much use to the Spaniards; early descriptions are limited to the classic image of the barbarian. All we learn about their origins is what José de Acosta, a leading Jesuit intellectual, wrote at the end of the sixteenth century: "These Urus are so stupid that they themselves don't take themselves for human beings. It is said of them that when asked what people they were, they answered that they were not human beings, but Uros, as if it was a different species of animals." 26

This opinion about the Chipayas and Urus became widespread and has been repeated endlessly. The Chipayas we spoke to still suffer from this image today (pers. comm., see also Text 2, $<\mathrm{C} 1: 3>$ ). However, if we read Acosta's description against the background of the contemporary Chipaya origin mythistory, it acquires a different, and less derogatory meaning: they were not human beings because they were of an earlier generation that had almost completely died out with the arrival of the sun-except for the Uru-Chipayas! Even in the twentieth century, the Chipayas insist that they are the oldest (and therefore only legitimate) people of the Altiplano.

The Chipayas have always been considered a special case: as we have seen, more often than not in a negative sense of the classical "other" or barbarian. Their own mythistory, although not static, has been conservative in the sense that the basic content has not changed. It is an excellent example of how it is not necessarily the text itself that undergoes changes but its interpretation by others or even by the authors themselves. Thus the reputation of the Chipayas

25 Ariel de Vidas (2008:49) analyzes in similar terms, those of "historical-mythical memory," the construction of the Mexican Huasteks' ethnic identity. It is interesting that their mythistory has a lot in common with the Chipayas': the flight from light as well as the perception of identity as being "no one" as opposed to the Spaniards.

26 "Son estos uros tan brutales, que ellos mismos no se tienen por hombres. Cuéntase de ellos que, preguntados qué gente eran, respondieron que ellos no eran hombres, sino uros, como si fuera otro género de animales" (Acosta 1954 [1590]: lib.II, cap. VI). Note that Acosta is careful to quote an unknown source for his statement. See also, for example, Métraux's image of the Chipayas' lives as dirty, miserable, and monotonous (1931:109). 
as being non-humans (which was already in place and probably created by the imperialist and utilitarian Incas ${ }^{27}$ ) fit into the Spaniards' ideas of all kinds of odd beings populating this foreign world - not too far from the earlier ideas of people without heads, and the ever-persistent Amazons and cannibals (cf., for example, Amodio 1993). At the same time it was a handy "misunderstanding" that helped the dominant Spaniards to further marginalize the despised Chipayas.

\section{Gaining and Losing Land}

The catastrophe of the sun was survived by a small group of people, the ancestors of the modern-day Chipayas. These survivors moved between two ecological areas: the hills (Capilla Perdida) in the north and the lake in the south (Text 2, $<\mathrm{C} 1: 1-2>$; Text $3,<\mathrm{C} 2: 2,4>$; see also Maps 3). Through these migratory movements they lost their land rights farther north and were finally confined to the lake area. Ever since, access to a variety of land and soils for different subsistence strategies has been a problem for the Chipayas living in the midst of Aymaras.

This episode can be explained in terms of century-old struggles between the Chipayas and their Aymara neighbors over land, which Wachtel (1990:336-48) corroborates with a detailed presentation and analysis of colonial documentation that dates at least to the seventeenth century. At times the Chipayas became servants of the Aymaras and were even used by them to pay off the Aymaras' mita (tribute in form of labor) obligations by being sent to the mines - for example, when they had lost an animal they had to pasture and had thus created a debt. On the other hand, there were times when Chipayas and Aymaras had reciprocal agreements for land and pasture use.

Today land is still contested by Aymaras and Chipayas. Sometimes stones are thrown at the neighbors. Title deeds are the subject of court litigation. ${ }^{28}$ It would be interesting to see what claims are the basis for the court cases for title deeds. In many Andean documents the only justification for owning land is that it has belonged to the owner "since time immemorial," an argument that is very clearly presented by our narrator: "We are the real established ones here, from before. They [the Aymaras] are people who came. [Added by the narrator in Spanish:

27 The colonial sources are mentioned in Dedenbach-Salazar Sáenz 2007a:4, n. 5.

28 "At present, the Chipayas have presented a territorial demand of 158,000 hectares as their original community lands; however, the indemnification of the lands has not begun yet" - according to our consultants, not by 2006 either. ("Actualmente, los chipayas han presentado una demanda territorial de 168.000 hectáreas para sus tierras comunitarias de origen [TCO], sin embargo el saneamiento de tierras aún no ha llegado." Anonymous 2005b; see also López Rivas 2004.) Felix Barrientos Ignacio (1990:35) gives the figure of 44,184 hectares as Chipaya land. The discrepancy between what the community has and what it claims seems too vast to have any chance of becoming reality. 
colonos, "colonists, settlers."] That's what grandfather said" < Text 3, C2:4>.29 Fifty years earlier F. Quispe had written (1955:139): “. . . our ancestors suffered from enslavement by the Aymaras; until today we are walled in by the Aymaras. There is no exit, no contact beyond the communityborders. They occupy most of our pastures. ..."30

\section{Surnames}

Chronologically most recent is an episode that narrates that the Chipayas went to Sabaya, a neighboring Aymara village, in order to "help" build the bell-tower (Illustration 7). There they were captured and baptized, receiving their surnames from a Christian priest (see Text 2, $<\mathrm{C} 1: 3>$, see Table 3). Thus they explain their surnames through their first contact with Christianity and through the difficult language situation in which they found themselves.

Although all the names are still seen today as typically Chipaya, not only are there many families of Aymara and of European descent that have these names, but in the story itself it is also made completely clear that they derive from Aymara, as Aymara words are referred to as their origin (see Text 2, $<\mathrm{C} 1: 3>$, footnotes 48 and 49). Moreover, some of the names are Spanish. ${ }^{31}$ On the one hand, this narrative is a recognition of the century-old domination of the Chipayas by Aymaras and Europeans; ${ }^{32}$ on the other, identifying with Aymara and European surnames and appropriating them as their own makes the Chipayas_although as descendants of the chullpas so essentially different from other Andean peoples - part of the larger Andean world. The imposition of the names through baptism can be seen as a key act of marking the

${ }^{29}$ According to one of our consultants, there are Aymaras who now claim to be descendants of the chullpas as well and thus hope to make their demand for territory as legitimate as that of the Chipayas. How a community's claim to land is explained and justified through mythistory can also be seen in the case of the southern Peruvian village of Sonqo, where Catherine J. Allen (1988:99-101) found the story that, after clearly marked and discontinuous earlier eras, the most recent one was said to be characterized by three leaders called Anton Quispe, each of whom carried in addition to this name the name of the respective neighborhood where he lived. As the previous generation had been wiped out, the new generation had to come from outside and yet be related to the community land.

30 “. . . que nuestros antepasados han sufrido una esclavitud de los aimaras[,] hasta hoy estamos amurallados por los aimaras[;] no [hay] salida[,] contacto [allá de los] límites intercantonal[es,] que ellos ocupan nuestros pastales[,] la mayor parte ..." ([sic]: the Spanish is that of a second-language speaker with little formal education; the translation is mine). E. Quispe (1985) gives a detailed history of the conflicts and of court litigation, partly based on (his understanding of) colonial and modern history. See also Iriarte 2009 for conflicts between Chipayas and Aymaras.

${ }^{31}$ A similar phenomenon of "appropriation" can be observed in religious and ritual terminology, which, in Quechua and Aymara, is often of Spanish origin and only used in Spanish, such as mesa, for offerings (derived from mesa, "table," or misa, "mass"), altomisayuq (derived from alto, "high," misa, "table" or "mass," plus the Quechua suffix -yuq which expresses possession), the Tío de la mina, "Uncle of the mine," a tutelar spirit of the mine workers, and many more (cf. Albó 1999).

32 The system of Christian first names and surnames was introduced by the Spaniards. Before the European conquest, Andean names were most often related to elements and phenomena of nature as well as supernatural beings (see Valiente 1984 for Quechua, Medinaceli 2003:183 for Aymara). In her historical study of Aymara names of a certain region in Bolivia, Medinaceli (2003:157-83) explains the complexity of the nascent colonial Andean name structure, based on a Spanish tradition that at the time was in transformation and on an indigenous tradition about which we know little. With respect to the Chipayas, F. Quispe (1955:136) writes that they used to call each other with the terms used for clothing (also E. Quispe 1985:12). 
Chipayas as the "vanquished," but the Chipayas themselves see this introduction to Spanish culture (language, baptism, surnames) as a step towards civilization (see Text 2: $<\mathrm{C} 1: 3>$ ).

What may look like an arbitrary array of folk etymologies actually represents the historical complexity of Andean society: the mixing of ethnic groups, such as Chipayas and Aymaras; the imposition of Spanish conventions and religion; and the translation, adaptation, and re-interpretation of this religion by the Andean people. Moreover, the uncertain origin of the Andean words (probably Aymara and/or Quechua) shows even more ancient underlying interethnic contact.

Table 3: The Names

\begin{tabular}{|c|c|c|c|c|c|}
\hline $\begin{array}{l}\text { Surname } \\
\text { Thought } \\
\text { to be } \\
\text { Chipaya }\end{array}$ & $\begin{array}{l}\text { Origin of Name } \\
\text { (Medinaceli: } \\
\text { 2003:Anexo 1]) }\end{array}$ & $\begin{array}{l}\text { Word } \\
\text { Deri- } \\
\text { vation }\end{array}$ & $\begin{array}{l}\text { Explanation by Narrator } \\
\text { C1 \{Explanation by } \\
\text { Quispe\} [comment by } \\
\text { SD] }\end{array}$ & $\begin{array}{l}\text { (Possible) } \\
\text { Etymologies } \\
\text { (a) Aymara } \\
\text { dictionary (Büttner } \\
\text { and Condori Cruz } \\
\text { 1984) } \\
\text { (b) Aymara } \\
\text { dictionary (Bertonio } \\
1984 \text { [1612]) }\end{array}$ & $\begin{array}{l}\text { Adaptation } \\
\text { Process }\end{array}$ \\
\hline Chino & $\begin{array}{l}\text { Andean }{ }^{33} \text { or } \\
\text { Spanish? } \\
\text { (Chinoca, } \\
\text { Chimo) }\end{array}$ & chinu & $\begin{array}{l}\text { because the person was } \\
\text { captured and tied with a } \\
\text { rope }\end{array}$ & $\begin{array}{l}\text { (a) chinu(-)_amarrar, } \\
\text { soga [to tie, rope] } \\
\text { (b) chino-tha-añudar } \\
\text { [to knot] }\end{array}$ & Aymara name (?) \\
\hline Lázaro & Spanish & lasu & $\begin{array}{l}\text { because the person was } \\
\text { captured with a lasso }\{\text { the } \\
\text { chullpas built the bell- } \\
\text { tower with clay and wild } \\
\text { straw that seems to have } \\
\text { been made into a kind of } \\
\text { lasso (136-37)\} }\end{array}$ & $\begin{array}{l}\text { (a) lasu(-)_lacear } \\
\text { ganado (cast.) [catch } \\
\text { livestock with a lasso } \\
\text { (Span.)] }\end{array}$ & $\begin{array}{l}\text { Spanish and } \\
\text { Andeanized } \\
\text { word is similar } \\
\text { to Spanish name }\end{array}$ \\
\hline López & Spanish & lupi & $\begin{array}{l}\text { because the person lives in } \\
\text { the sun [strange because } \\
\text { the Chipayas were } \\
\text { originally afraid of the } \\
\text { sun; Quispe's explanation } \\
\text { is more feasible:]\{Lupi } \\
\text { was baptized during the } \\
\text { day, by the light of the sun, } \\
\text { (137)\} [that is, he had } \\
\text { already made the first step } \\
\text { to come out of the } \\
\text { darkness] }\end{array}$ & $\begin{array}{l}\text { (a) lupi-rayo del sol } \\
\text { (b) lupi-rayo del sol, } \\
\text { o resplandor [sun ray } \\
\text { or sunshine] }\end{array}$ & $\begin{array}{l}\text { Andean word is } \\
\text { similar to } \\
\text { Spanish name }\end{array}$ \\
\hline Huarachi & Andean & $\begin{array}{l}\text { warac } \\
\text { hi }\end{array}$ & $\begin{array}{l}\text { because the person has } \\
\text { been sprinkled with water } \\
\text { [baptized?] }\end{array}$ & $\begin{array}{l}\text { (a) wara(-)_derramar } \\
\text { agua } \\
\text { (b) huara-tha- } \\
\text { derramar agua [to } \\
\text { sprinkle water] }\end{array}$ & $\begin{array}{l}\text { Andean word is } \\
\text { identical with } \\
\text { Aymara/ } \\
\text { Quechua name }\end{array}$ \\
\hline
\end{tabular}

${ }^{33}$ See footnote 17. 


\begin{tabular}{|c|c|c|c|c|c|}
\hline Quispe & $\begin{array}{l}\text { Andean } \\
\text { (Quispe) }\end{array}$ & qispi & $\begin{array}{l}\text { because the person has } \\
\text { been rescued [saved?, } \\
\text { word used in Christian } \\
\text { texts] }\end{array}$ & $\begin{array}{l}\text { (a) qispi(-)_-salvar [to } \\
\text { save] } \\
\text { (b) quespi-cosa } \\
\text { resplandeciente } \\
\text { [something shining] } \\
\text { saluar-quespia-tha } \\
\text { [to save] } \\
\text { also Quechua }\end{array}$ & $\begin{array}{l}\text { Andean word is } \\
\text { identical with } \\
\text { Aymara/ } \\
\text { Quechua name }\end{array}$ \\
\hline $\begin{array}{l}\text { Pirqa; } \\
\text { Paredes }^{34}\end{array}$ & $\begin{array}{l}\text { Andean } \\
\text { (Pirca); } \\
\text { Spanish }\end{array}$ & pirqa & $\begin{array}{l}\text { because the person was } \\
\text { closed into a house } \\
\text { ("walled in") \{because the } \\
\text { chullpas had constructed } \\
\text { the bell-tower wall (137)\} }\end{array}$ & $\begin{array}{l}\text { (a) pirqa-pared } \\
\text { (b) pirca-la pared } \\
\text { [wall] } \\
\text { also Quechua }\end{array}$ & $\begin{array}{l}\text { Meaning of } \\
\text { Spanish word is } \\
\text { translated into } \\
\text { Andean } \\
\text { language OR } \\
\text { Andean word is } \\
\text { adapted to } \\
\text { Spanish surname }\end{array}$ \\
\hline
\end{tabular}

\section{F. Quispe (1955) gives further names:}

\begin{tabular}{|c|c|c|c|c|c|}
\hline Felipe & $\begin{array}{l}\text { Spanish } \\
\text { (Lipi) }\end{array}$ & $\begin{array}{l}\text { lipinta } \\
\text { ta } \\
\text { pfelipi } \\
=\text { llipi }\end{array}$ & $\begin{array}{l}\text { \{because the chullpas had } \\
\text { trapped themselves in the } \\
\text { ropes the Aymaras had put } \\
\text { up as obstacles in order to } \\
\text { capture them }(136-37)\}\end{array}$ & $\begin{array}{l}\text { (a) llipi-trampa para } \\
\text { cazar aves [trap to } \\
\text { hunt birds] } \\
\text { (b) lipi-soga con que } \\
\text { rodean ganado, o las } \\
\text { vicuñas para que no se } \\
\text { huygan, por miedo de } \\
\text { vnos fluecos de lana } \\
\text { que cuelgan de la soga } \\
\text { y se menean con el } \\
\text { ayre [rope with which } \\
\text { they circle livestock, } \\
\text { or the vicuñas, to } \\
\text { prevent them from } \\
\text { escaping, because they } \\
\text { are afraid of some } \\
\text { wool-tassels that hang } \\
\text { from the rope and } \\
\text { move in the air] }\end{array}$ & $\begin{array}{l}\text { Aymara word } \\
\text { sounds similar to } \\
\text { variant of } \\
\text { Spanish name }\end{array}$ \\
\hline Alavi & $\begin{array}{l}? \\
\text { (Alavi) }\end{array}$ & alala & $\begin{array}{l}\text { \{the chullpas walked at } \\
\text { night in the light of the } \\
\text { moon }(137)\}\end{array}$ & $\begin{array}{l}\text { (a) alalaw/ alalay- } \\
\text { iqué frio! } \\
\text { (b) alalay- } \\
\text { interjección de vno } \\
\text { que padece frio [both } \\
\text { exclamations of } \\
\text { someone who suffers } \\
\text { cold] } \\
\text { also Quechua }\end{array}$ & Aymara? \\
\hline
\end{tabular}

34 The surname now used is Paredes, the Spanish equivalent of the Andean word pirqa. According to our main consultant there is still one man called Pirqa in Chipaya, but he has no family who could carry on the name. 


\begin{tabular}{|c|c|c|c|c|c|}
\hline Villca & Andean & willka & $\begin{array}{l}\text { \{the Aymaras made them } \\
\text { come out of the lake with a } \\
\text { sign of the hand }(137)\}\end{array}$ & $\begin{array}{l}\text { (a) willka-Dios Sol } \\
\text { (antig.) [Sun-God } \\
\text { (obs.)] } \\
\text { (b) villca-el sol como } \\
\text { antiguamente } \\
\text { decía. . . ; adoratorio } \\
\text { dedicado al sol... } \\
\text { [the sun as they used } \\
\text { to say in former } \\
\text { times ... ; adoratory } \\
\text { dedicated to the } \\
\text { sun ... . ] } \\
\text { also Quechua } \\
\text { (probably from } \\
\text { Aymara) }\end{array}$ & $\begin{array}{l}\text { Andean word is } \\
\text { identical with } \\
\text { Quechua/ } \\
\text { Aymara name }\end{array}$ \\
\hline Copa & $\begin{array}{l}\text { Andean or } \\
\text { Spanish? } \\
\text { (Copa) }\end{array}$ & copa & $\begin{array}{l}\text { \{because they became } \\
\text { friends and had alcoholic } \\
\text { drinks from a goblet } \\
(137)\}\end{array}$ & $\begin{array}{l}\text { (a) qhupa-escarcha } \\
\text { [crystallized frost] } \\
\text { also Quechua } \\
\text { (b) copa-luciérnaga } \\
\text { [glow-worm] } \\
\text { kopa-tha-apretar con } \\
\text { la mano [to squeeze } \\
\text { with the hand] } \\
\text { and Spanish: } \\
\text { copa, goblet }\end{array}$ & $\begin{array}{l}\text { Spanish word } \\
\text { interpreted as } \\
\text { Chipaya name; } \\
\text { possibly also } \\
\text { Andean word } \\
\text { used for names }\end{array}$ \\
\hline
\end{tabular}

Eduardo Quispe (1985:6-7) supplies more surnames: "Machaca (new people [Aymara: mächaqa, 'new']), Cruz (blessed with the cross [Spanish: cruz, 'cross']) and Ramos [Spanish: 'bouquets,' maybe from Domingo de Ramos, Palm Sunday], Cayo (it is because they came on foot [Aymara: kayu, 'foot']), etc. . .."35 José Condori (1982:12) adds Chico and Guaca. ${ }^{36}$

This episode reflects European chronology: colonialization and Christianization; whether it does so by drawing on Andean ways of building memory or reflects colonial-era Christian teaching is unclear-probably a combination of both. On the other hand-like the others - it is aetiologial since it explains not only the modern surnames, but also, and importantly, Christianization and the interrelation of the Chipayas with old Andean traditions (for example, hunting with bolas), with their Aymara neighbors (some surnames are frequent in the Aymara population), and with the Spanish and Christian world (in the case of the Spanish surnames). However, in order to relate clearly this variety and multiplicity of influences back to themselves, the explanations are mythistorically and folk-etymologically derived from the Chipaya language. ${ }^{37}$ As individual narrators have partially different "typically Chipaya" surnames, it is

35 "Machaca (nueva gente), Cruz (bendecido con la cruz) y Ramos, Cayo (es que vinieron a pie) etc. . .."

36 Condori does not explain the names. Medinaceli has Cayo, Condori, Chico, and Guaca. Jesús de Machaca is a village not far from Irohito where the present-day Urus live (see footnote 47).

37 It is possible that, in etic terms, the names reflect marriage practices and ethnic exogamy and that, in emic terms, the Chipayas, although they must have integrated substantial numbers of outsiders, have managed to convey the image of being a closed society that is exclusively Chipaya. 
possible that certain families or ayllus (communities; territorial or kin groups within a community) create folk-etymological explanations for their own group's names.

\section{Interpreting Chipaya Mythistory: The Creation of Community Cohesion and Identity}

The episodes of the story that relate migratory movements and surnames show that according to their memory the Chipayas have always lived in a tense relationship with the Aymaras. It seems that the Aymaras were also in the area from early times (our consultant $<$ Text 2, C1:3> refers to Sabaya as always having existed). According to Chipaya mythistory, contact and tension were present in the remote past when the Chipayas became limited to a small territory by Lake Coipasa. At that time Aymaras and Chipayas apparently belonged to different "kinds" of people (not unlike what is reflected in the Acosta narrative): the Chipayas moved about in the darkness and lived from fishing, hunting, and gathering, whereas the Aymaras lived by daylight and were herders and peasants. An indication of the complex interpretation of the past is the place called "Capilla Perdida" ("Lost Chapel"). The Chipayas lost the place to the Aymaras because they forgot to go back regularly. It was originally their place, yet it is designated with a Spanish place name and may have received the qualifier "lost" when the Aymaras took it over.

Contact was not always conceived of as negative, yet the story says that the Aymaras gave the Chipayas sheep so that they could start breeding animals (see Text $1:<\mathrm{M}: 3>$ ). The Chipayas mainly construct their difference as a disadvantage. They went to Sabaya to help build the bell-tower of the church. They belonged to another era, literally to the night, so they could not work during the day, which robbed them of the opportunity to interact with their neighbors. They had to work at night and were eventually captured by the Aymaras (with the same means used to capture wild animals). Contact could only be established once the Chipayas had learned Aymara. The Aymaras collaborated with the Spaniards, first against the Chipayas by capturing them, then through accepting their baptism by the priest, so that the Chipayas could be transformed from "uncivilized people" into Christians and thus integrated into contemporary humanity. Two of the names, which are of Spanish origin, refer to the way the Chipayas were captured, by lasso-Lázaro, and by enclosing the person within walls-Paredes; two other names, however, are of Aymara origin and refer directly to Christianization: one person was "sprinkled," that is, baptized, and is therefore called Huarachi; the other one was "saved" (using in Aymara the Spanish word salvar, but in Chipaya the Aymara word qispi-) and therefore becomes Quispe. However, by assuring that the names are typically Chipaya, in mythistory the boundaries between Spanish, Aymara, and probably also Quechua origins become blurred. Anything "really" (in our terms) identified as Aymara or European becomes Chipaya; the other is integrated into one's own naming system, and non-Chipaya names are given a Chipaya etymology (which linguistically is not Chipaya), thus creating a unique identity, different from everyone else and yet closely related to the neighbors. Of course, such cognomens also occur in 
Aymara families, but in contrast to those they are the only Chipaya surnames: community members with other Aymara names, such as Mamani, are declared not authentic Chipaya. ${ }^{38}$

In this way the Chipayas' uncivilized status and identity is transformed and literally translated into a civilized, Christian status and identity. Plate (1999:7) captures this appropriation of the other as follows: "The other, by definition, cannot be defined. If the other can be discussed and thereby brought into the symbolic order, it ceases being other." Applying this idea to the cultural sphere of the Chipayas and their neighbors, we can say that they bring the other into their own symbolic order and thereby blur or even dissolve clear boundaries of identificationthe Aymaras cease to be other because the Chipayas use Aymara names (at least names explained through Aymara words). In a way, the Chipayas incorporate the others into their own cultural identity while at the same time maintaining them as others by laying claim to the names as specifically Chipayas'. Clear identifying boundaries fade and modern Andean society with its fusions and tensions is thus explained and justified.

Variants in the overall discourse of Chipaya mythistory show the complexity of shifting meaningfulness. The versions we recorded clearly depict the Chipayas as uncivilized and the Aymaras as their enemies, whereas the 1955 narrative shows a more peaceful image: the Aymaras were appreciative of the secret help with the construction of their bell tower and wanted to get to know the helpers; the Chipayas wanted to belong to the Aymaras and become Christians, and they therefore helped build the tower (F. Quispe 1955:136; also E. Quispe 1985:4). Eduardo Quispe (idem) also makes it explicit that the priest ordered the Aymaras to capture the chullpa-Chipayas. The explanations found in the older stories are missing from the modern stories probably because they have been lost, but it is possible that for the Chipayas there is hope now that the situation can be changed through political action, and therefore an explanatory framework that is more conciliatory has been replaced by a more confrontational one.

Five hundred years later, the Chipayas, or at least some of them, are now empowered, by the descendants of the colonial powers, with the classical Western capacity to read and write. However, they maintain their oral tradition, and they adapt it — as they did before, and as the Spaniards did for their purpose - to their immediate concerns. An example of this adaptation is our consultant's opening of his narrative where he relates Chipaya mythistory geographically and thereby culturally to Lake Titicaca, several hundred kilometers further north, and to Lake Poopó, a considerable distance to the east (Text $3,<\mathrm{C} 2: 1>$ ):

I will tell of the life of our forefathers, narrated by the grandfather, narrated by our forefathers. We always lived on this big lake, on the Titicaca, also on the Poopó, also on the Coipasa, we always lived on the lake, it is said. We came from the North, from the big Lake Titicaca, the Desaguadero, along that river we arrived at Oruro, at the lake of Oruro. And we, one group, came from the West, from the Lauca, as we now call the river. ...

38 This practice, however, depends on the context. When there is resentment against a certain person by others (as was the case with an important functionary in 2005), some community members will claim that, as his surname shows, he is not really Chipaya, but they may have the name in their own family without seeing any contradiction in their statement. Cf. Barrientos Ignacio 1990:50. 
From the introductory information disclosing that the forefathers had told this story, the listener (or reader) receives the impression that this is ancient memory. While that may be so, there is some indication that it was only in the twentieth century that the Chipayas integrated this knowledge into their own version on the basis of what anthropologists told them. Alfred Métraux (1931:100) and Nathan Wachtel $(1990: 226-32,280)^{39}$ state that the Bolivian Titicaca Urus, the Chipayas, and the Muratos did not have any knowledge of each other. But by the beginning of the twenty-first century, the consciousness of sharing the same culture has become part of the political discourse of the Uru-Chipaya groups (as demonstrated in a meeting in Oruro witnessed by the author in July 2005). It strengthens their new or re-found identity as an "Uru nation." Looking at present-day life in these villages, the Chipayas have little in common with the Urus and Muratos: in terms of subsistence they no longer depend on water-based fishing and hunting (and have not for many years), but rather on herding and agriculture; with respect to their own language, only the Chipayas speak it at present. However, historical documentation, and also photographs from the first decades of the twentieth century, show similarities in architecture and clothing, and the strong relationship with water that the Chipayas still feel is a further indicator that they once formed part of the Uru "aquatic axis" (Wachtel 1990:350-57). Rather than an invention of a joint tradition, this seems to be an externally stimulated memory of a shared past, re-incorporated into contemporary mythistory by our narrator.

One of the issues that many indigenous groups have to deal with is title deeds for their land. In the case of the Chipayas, this is above all their need to gain or at least not to lose more fertile land to the neighboring Aymaras. This is a matter where the antiquity of their origin plays an important justificatory role. Based upon being the sole descendants of the primeval era, they automatically have land rights that go back much further than those of any other Altiplano group. Thus the chullpa story serves a timely purpose, namely to make and justify territorial claims.

The narratives show that the Chipayas construct their mythistory in order to portray themselves as the most ancient people of the region. Their area is practically defined through their mythistory: the lake to the south (Coipasa, which was larger than it is now), the barren plain where Chipaya lies, and hills in the north (Maps 3). This construction implies their ancient rights to live there. In spatial terms this can be seen as an indigenous method of mapping the territory; in terms of chronology the most ancient memory is designated, an era that we would call "prehistoric times." The fact that there are still burial buildings called chullpas conserved in the Altiplano, some close to Chipaya, connects the present to the past and at the same time creates a physically existent territory that is justified by oral, mythistorical tradition and visual, archaeological evidence.

\section{Conclusions}

The Chipaya mythistory as a whole fulfills a number of functions: it explains the delimitation of the territory (which is still in dispute, more land recently having been formally

\footnotetext{
39 Wachtel traveled in 1974 and 1976 with some Chipayas to the Muratos, and in 1978 with some Chipayas and Muratos to Irohito (Urus on Lake Titicaca).
} 
claimed by the Chipayas); it also explains both the tensions with the neighboring Aymaras over territory as well as the continuing relationships with them, as they intermarry and Chipayas live in Aymara villages. The mythistorical narrative also establishes permanent relationships with the Aymaras and mainstream Bolivia (formerly Christian-Spanish society) through the Spanish and Aymara surnames, which at the same time are distinctly Chipaya because of the etymologies provided. What may at first look like a curious and arbitrarily blended composition turns out to be a meaningful and therefore community-strengthening explanation for who the Chipayas are, why they are who they are, and why they are where they are-in other words, a coherent mythistoriography.

Their origin is conceived of as special and different from the other surviving Andean peoples, and yet their more recent identity - through their names - is closely related to their Aymara neighbors and the dominant Spanish-language-based national culture. This close relationship with, and in part direct interpretation of, mythistory as relevant for present-day life explains why it is common knowledge today. Chipaya mythistory is used to explain a complex identity that involves Andean as well as European roots and that relates the people to their neighbors by interlacing important events and concepts. Thus a mythistorical narrative ties together what is vital to Chipaya self-comprehension and definition: an origin rooted in their present territory, the explanation of their close relation to the aquatic world, and the reasons for their being hunters and fishers as well as peasants and herders. At the same time, all these achievements and self-defining elements root them in Andean prehistoric and colonial society, relating and attaching them to their neighbors and providing explanations for their ambiguous relationships.

While Chipaya architecture, clothing, and even language are losing importance as vital means of self-identification, the mythistorical narrative is ever-present, and the memory of the chullpa ancestors and what followed after their disappearance still has a palpable effect on people's lives, in their names as well as in their relationship with the neighboring Aymaras. Chipaya mythistory reinforces the feeling of commonality, of belonging to a community. It separates the group from others and at the same time ties it to them.

As for the narrators of Chipaya mythistory, the basic content is known by every member of the group. For some it is simply a story one knows (like the language one speaks), without necessarily applying it consciously to any practical purpose. Others use the mythistory to propound their particular point of view, like Wachtel's consultant who gives a pentecostal version that integrates elements of Chipaya mythistory into his scenario of the end of the world, when, as in the ancient times, only some people will survive: after the disappearance of the sun and the moon, a fire-rain will come and the survivors will be like the chullpas (Wachtel 1990:636-37). ${ }^{40}$ For yet others, the narrative becomes an overt historico-political instrument in their interaction

${ }^{40}$ Christian elements are also found in the mention of the Great Flood by our consultant $($ Text $3,<\mathrm{C} 2: 3>$ ) and in the story "Las chullpas de Coipasa" collected by Porterie (M. Quispe 1984). F. Quispe (1955:134), for example, writes that the destructive sun came out at Easter. José Condori (1982) and Eduardo Quispe (1985) relate the sun disaster to the final judgment. 
with the Bolivian authorities ${ }^{41}$ in order to achieve concrete goals, in this case certified land rights. Those who are community-elected or self-named representatives, especially the members of CILNUCH (the Council for the Implementation of the Native Uru-Chipaya Language), are the ones who interact most with supposedly influential outsiders. Similarly to historians in our society, these representatives work to create an authoritative narrative to explain the past, to help understand the present, and to shape the future.

Thus the Chipayas' mythistorical narrative fulfills multiple purposes, all of which reflect the concept of mythistory as presented above. Past events are brought together in a narrative that aims at reinforcing and maintaining the group's cohesion and identity. The narrators and the context of the narration play an important role, especially when, in public discourse, they legitimize the Chipaya point of view and are used for concrete political objectives. This manifold function makes mythistory a highly creative, flexible, and practical narrative.

University of Stirling

${ }^{41}$ When telling us outsiders his story, our consultant (Text $3,<\mathrm{C} 2: 4>$ ) mentions explicitly the supposedly long-standing consciousness of the Uru-Chipaya groups as being related; he also emphasizes that the Aymaras are newcomers. This emphasis shows that he tries to influence and even mold our image of his people, much like a historian with a certain agenda. 


\section{Appendix $^{42}$}

Text $1<\mathrm{M}>$

Chipaya mythistory narrated by a consultant to Alfred Métraux (1935b:396-97) in Chipaya. ${ }^{43}$

$<\mathrm{M}: 1>$

In the old times, they say, the sun rose from the west.

Toki tiempo taxata tuñi š-tekuškiskij̄a.

Thus [they said]: "Let's build our doors towards the east."

Nekstan: "Tuanču sančis čum k koila."

Then the sun rose from the eastern parts.

Nekstanaki tuanta-naka tuñi tekskuči.

Then the people died at the entrance of their houses.

Nekstanaki kºil-kama-lus šoñi-ki tiksi.

Then they all died in their houses.

Nekstanaki k ${ }^{\mathrm{x}} \mathrm{oi}-1$ pača tiks.

Thus the sun killed the chullpas.

Tuñi š-tikskalǰa (tiskškaja) čul'paki.

Then [some] got into the water, they escaped.

$\mathrm{K}^{\mathrm{x}}$ askis luškalj̄a, tisk ${ }^{\mathrm{x}}$ apkalj̄a,

Then these people (this couple) lived in this

Chipaya village.

This Chipaya village is in a bare place.

nekstan šetkal̆̄a ${ }^{44}$ ni šoñiki (luk $\left.{ }^{x} u t u n ̃ i\right)$.

In the bare place they built their houses.

Ti Čipaya watkis k ${ }^{\mathrm{x}}$ ar watkis šelja.

From two persons the Chipayas multiplied.

$\mathrm{K}^{\mathrm{x}}$ ar watkis $\mathrm{k}^{\mathrm{x}}$ oya-tkalja.

When the sun rose, they would go into the water.

Pukultanšoñikistan mirk alȳä Čipayaki.

Tuñi teuktan (teukštan), $\mathrm{k}^{\mathrm{x}}$ as-kis lušnitakalǰa.

42 Rather than applying strictly syntactical criteria for marking units in the texts, I have opted for a mixture of phrases/clauses and rhythmic units that emphasize stylistic features. One of the most important issues in some circles of the Chipaya community is the alphabet. Toward the outside it is used as a symbol of identity, uniqueness, and unity. At the request of the community, the Bolivian government through a ministerial resolution declared the alphabet the Chipaya linguistic committee had elaborated as official (Anonymous 2005a, cf. Dedenbach-Salazar Sáenz 2007b). Despite this token of unity, different alphabets are being used. Deeper tensions within the village surface when some community members boycott each other's alphabets in order to highlight their disagreement. The texts in this Appendix follow their authors'/creators' orthographical conventions.

43 The text was first published in Spanish by the Swiss anthropologist Alfred Métraux in 1931 (112-13), dictated to him in Chipaya by the "oldest man of the tribe" ("el hombre más viejo de la tribu"); he then had it translated into Aymara (112). The Chipaya text appeared in a French (Métraux 1935b) and in a Spanish version (Métraux 1935c). I made the English translation from the Chipaya text (published in Métraux 1935b), and it was then verified by our consultant (C2). I have kept Métraux's original transcription. He explains the Chipaya sound system and his orthography (1936:340-42) and mentions it also in 1935a (89-90): “č correspond au «ch» espagnol, ̌s $\mathrm{au}$ «ch» français; $\mathrm{j}$ est une affriquée qui en français serait transcrite par «dj»; $\mathrm{x}$ est le «j» espagnol et l' le «ll» ou 1 mouillé de la même langue. Le signe combiné $\mathrm{k}^{\mathrm{x}}$ est une mi-occlusive dont la détente produit un son voisin du «j» espagnol ... ." Although Métraux (1935b:398) considered the text to be a disfigured and altered fragment of an older myth, the present setting of the text shows a certain stylistic pattern.

${ }^{44}$ Métraux (1935b:396) has renaquirent in his French translation; in his Spanish version the verb is written "šatkalja”" and translated as renacieron (1935c:65). Our consultant translated as follows from the Chipaya in the Spanish edition: habia corrido, "had run," from the verb śat-ś, "to run." Since the French version has šetkalja, this would be "they/he lived," derived from źelh-ś, "to be, exist," also źeti, "life, health" (for the vocabulary, see DOBES Project 2007). 
The two escaped.

When the sun sank at night, coming out of the water, they would walk around.

$<\mathrm{M}: 2>$

A man saw the chullpas, and he went to tell the authorities.

The priest came, then he blessed them. ${ }^{45}$

$<\mathrm{M}: 3>$

In the old times they pastured sheep in Huachacalla.

Every year the Huachacalla people gave them a sheep.

From one sheep they multiplied,

then there were many sheep.

In the old times, the chullpas had not had sheep;

they cultivated cañahui and quinoa.

They started living [appeared] in this village of Santa Ana, in a bare place.

In the old time they lived over there in Sabaya, the Chipaya people.
Pukultan tisk ${ }^{\mathrm{x}}$ apkalja.

Tuñi $\mathrm{k}^{\mathrm{x}}$ atanaki wen, $\mathrm{k}^{\mathrm{x}}$ askistan ulšku ok $^{\mathrm{x}}$ lañitakalja (ulšnok lañitakaljä).

Šinta šoñiki čertajă čulpaki iliriškis mastakaljä (parto taak ${ }^{\mathrm{x} a l j a ̈)}$.

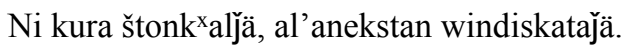

Toki tiempo uši isñitak ${ }^{\mathrm{x}} \mathrm{aljä} \mathrm{Wačakal'akis.}$

Sapa wata tsi usi laknitakªlǰ̨̨ Wačakal'ia-šoñi.

Tsi usakistan mirinitakaljä,

al'anekstan tamakisij̃a usa.

Tuki tiempo anatakaljä oiwičis čulpaki;

kañavi, $\mathrm{k}^{\mathrm{x} u l a}$ čaknitakaljä niki.

Ti Santana watkis kªr watkis paresitkalǰ̨̧.

Toki tiempo Sabayakis tękis šelxni Čipaya.

Text $2<\mathrm{C} 1>$

Chipaya mythistory narrated to Sabine Dedenbach-Salazar Sáenz by a consultant in $2002 .{ }^{46}$

$<\mathrm{C} 1: 1>$

Well, I will tell a story of the lives of the ancestors.

In very ancient times this village of Chipaya did not exist, they say.

The village was in the north, where Capilla

Perdida [Lost Chapel] is, it is said;

so there was the village. bueno werh tshi k'int'asaćha tukita timpu mathñillaź qamta

tukit tuki timpuki ti chipay wathak tiw ana źelatćha khićha

wathaki nawkh uźa kapilla perdida khita

xalla niwkhutakiź wathaki

45 Métraux comments that he was told that the blessing was to make them abandon their nocturnal life (1935b:397).

46 One evening the then seventy-two-year-old man came to see us to tell us about his life. He insisted on being audio-recorded, and when he had finished his well-prepared life story, I asked him spontaneously about the origin of the Chipayas. He then told us - a collaborator and myself - the following story, first in Chipaya, then in Spanish. This is my translation of the Chipaya narrative (after having had it transcribed and provided with a draft translation by a Chipaya consultant, I verified and reworked the transcription phrase by phrase with another consultant). The alphabet used is very close to the official one and has been developed among project members and consultants. eCompanion: http://journal.oraltradition.org/issues/27i/dedenbach-salazar_saenz\#myGallery-picture(11) 
And there was a lake here.

Here, by the shore was a lake, a big lake.

There were fish, birds, eggs.

So those Chipaya people used to come here, it is said, to fish and to kill birds.

They also went back north to Capilla Perdida, it is said.

That was very far away - they got tired;

so they, the people, built a house over here, a small house.

That little house must have been called ch'ipha.

Then, they also made a boat of rush, so they could enter the lake.

So over here in the little house they used to leave the boat.

Thus then they walked and walked more, until from Capilla Perdida they came exactly to this village, to this ch'ipha village.

Over here they built many houses until they did not go back there, not to Capilla Perdida; they left it.

So then gradually, until now, the people probably multiplied.

So, that what was called ch'ipha was a little house; then it must have become a whole village.

Afterwards, in the end, it must have become Chipaya;

so then, now this village is Chipaya.

Then this village was called Chipaya;

first, it is said, it had been called ch'ipha.

Thus is the tale of the old times.

$<\mathrm{C} 1: 2>$

Now even Capilla Perdida has definitely been lost; now the Aymaras have taken it away.

These ancestors never thought of it [that they should have also stayed in Capilla Perdida so as not to lose it to the Aymaras].

They certainly should have gone towards the mountain there.

This is how it is now: one cannot go towards the mountain; neqhśtan teqhś tshi qota źelatkiź

teqhśi tï ti thïkiś qota paqh qota

neqhś ch'iśnaka weślanaka śiñinaka źelatź

xalla nikhtan niwkh chipay źonakak thonchikiź tiwk ch'iśtani weźla koni

neqhśtan uźaśaq qaqhćhan kapilla perdida khita xalla niwkhu

neqhśtan aźkinpacha xayraśśiki

ninaka ni źonaka neqhś tshi qhuya qhuychikiź teqhś tshi qhuyalla

ni qhuyallak ch'ipha khitatakiźni

neqhśtan tshi warkuśaq phitkiśtan pächitakiź xalla ni qota luśśapa

xalla neqhś ni qhuyallkiś ekñitakiź ni warku

xalla neqhśtan iya niźta oqhlaychi oqhlaychi hasta ni kapilla perdidkiśtan q'ala tiwk thoñchikiź ti wathkiś ti ch'ipha wathkiś

neqhś wakchi qhuyanaka qhuychikiź hasta ana ni kapilla perdida ana niwk oqhchikiź ekchikiź

xalla neqhś ni wiri wiriñ hasta teqhś mirćhan źonakaki

xalla neqhśtan ni ch'ipha khita qhuyallak

hasta wathapachallaźlan

neqhśtanak oltimkiś chipaya

xalla nuź thuthźtaźni xalla neqhśtan anś chipaya ti wathak anś

nuźkhita thüchiś ti wathak chipaya

piramira ch'iphataź khiź tik ch'ipha

nuźuź ni tukita kintuki

xaśik hasta kapilla perdidam pertitaź

xaśik toźaqaś hasta qhañchi

ti mathñillanakak ana wira pinsichiź

nuk'an nawk kurqhuñi oqhchukataqalź

nik xaśik yasta anaź kurqhuñi oqh 
everything there has an owner;

the Aymaras took it away [from us].

So now this [village of] Chipaya is what is

left of the chullpas;

it has remained from the chullpas.

$<\mathrm{C} 1: 3>$

And there is also another story.

In the old time only the moon existed, the moon, they say.

These chullpas used to work in the moonlight only.

So they herded the vicuñas only at night.

Ah, in Sabaya [its people] worked at the bell-tower - the Aymaras in Sabaya.

(Illustration 7.)

It seems that the village of Sabaya has always existed;

there was definitely always a priest over there.

Then they arrived at the bell-tower over there-

thus our ancestors suddenly arrived there.

Well now, they moved the stones;

they wanted to build a wall. ${ }^{47}$

They must also have come at night.

On the following day the Aymaras

followed the footmarks;

oh- the stones had been moved-

"What persons have moved them?"

"So we have to watch out, to catch them,"

thus agreed the Aymaras from Sabaya. tuñuchhkamaź

toźak hasta qhañchićha

nuźuź añś ti chipayak chullpa puchućha

chullpikśtan źetchićha

niźaśa tshi kintuśaqa źelhćha

tuki timpu hasta jiš́qa źelhñitakiź jïś

jiśkiśqa trawajñitakiź ti chullpanakaki

neqhśtanak ap apchikićha hasta oka wen

wa śawakiś kampanturi lanqźnatkiź ni śawa toźanakak

ni śawa ni watha pantaźkhil

kurami źelatźkhil neqhśi

xalla ni kampanturi neqhś neqhś

makhatchikiź neqhś thamxatchikiź ni awilunakaki

yaw ni thisinchikiź ni maśnaka

pirqiś pekchikićha

wen śaqa thonćhan

xaqataźuk hasta ni toźanakak qhxocha thoqćhan

wa thisinta ni maśnaka

ćhhul źoñit thisin nik

hasta źwila źtanla

xalla nuź qaśśikiź ni śawa toźanakaki

47 Wachtel (1990:222) shows that the bell-towers are mallku, powerful beings, following in power and importance the highest mountain peaks (cf. 57-58). From the perspective of the Sabayans themselves the bells were particularly important because they sounded three times in order to mark the arrival at mass of Tata Sabaya, the patron spirit of the Sabayans, who resided in the mountain of the same name. Once, when Tata Sabaya arrived late and the priest had started mass without him, Tata Sabaya locked the priest up. When he was freed, he excommunicated Tata Sabaya and the whole village. The village fell into decay and was repopulated later (Rivière 2008:98-99). Maybe both stories contain the same element - the necessity to rebuild the bell-tower-but contextualize it in different ways that are meaningful to each group.

An interesting parallel with Chipaya mythistory is Lorenzo Inda C.'s narrative on Uru mythistory, which tells how the church of Jesús de Machaca kept falling apart while it was being built. Therefore, sacrifices (animal and human) had to be made, and Urus were abducted and sacrificed there, so that the church-according to Inda C. (1988:29) - was built with the blood of the Urus (cf. Astvaldsson 2000:253). While this story seems to differ substantially from the Chipayas' relation with the church in Sabaya that they wanted to help to build, the unstated outcome is similar: a difficult relationship with the neighbors and yet a certain affiliation with them through being part of the process of building the churches in the neighboring Aymara villages. 
Then at night they must have come then.

As a matter of fact people came, very large people [the Chipaya people] came, immediately.

Soon they [the Aymaras] captured them,

some six persons,

that's how many they captured;

some persons escaped.

After having caught them, they bound them;

then they walled them up in a house.

Afterwards they took them to the priest;

nothing did they understand, neither

Aymara nor Spanish,

they must have spoken [only] the Chipaya

language, the Puquina language. ${ }^{48}$

Then for some time they must have been like this;

then afterwards they must have learned Aymara,

those people, those uncivilized people.

Then afterwards the priest asked them,

"How did they catch you?"

"I was caught with a lasso," he [one of them] said,

"I was caught with a lasso."

Saying "Lázaro," he [the priest] gave him that name then, Lázaro.

Then,

"After they captured you, what did they do to you?"

They bound him;

then he must have said, "I was caught with a rope."

"Ah, so [it is] Chino [The One Tied With A Rope]," thus saying, the man [the priest] named him so.

"After they captured you, what did they do to you?"

"I was closed into a house, I was walled in," he said.

"Ah, then you would be Pirqa [Wall], now you will be Pirqa [Wall]." hasta hasta wen hasta thonaćhan hasta hasta

cheqapan thonchikiź źonaka nuspa lachhś źonaka thonchikiź ni tirikchukpacha

wax tantakiź

hasta ni źonaka tshi soxta

hasta niźta tantakiź

parti atipchikiź źonaka

tanź hasta ćhelhtakiź

hasta qhuykiś pirqantitakiź hasta

neqhśtan kurźkin chhichhtakź

ana wira intintikiź ninaka aymara anaśa kastillanu

hasta chipay taqut chïchan pukin taqu

xalla niźtikiśtan aźqa nik źelhćhan

xalla neqhśtanak aymara niki yateqchiźlani

ni ni źonakak ni k’it źonakaki

xalla neqhśtan kuraki pekunchikićha

qhaź tantat am khikan

werhk lasuntitu xalla nuź khichikiź

lasuntitu

lasaru khikan nik hasta thü qhaychikiź lasaru

neqhśtanak

tanźku qhaź khitat am

ćhelhchićha

hasta chinuntitu khićhan

a entonces chino xalla nuź khikan tshi źoñik qhaychikiź

tanźku xaśi am qhaź khitat

werhk qhuykiś chawkźtaź pirqantitaź khiź

a entonces pirqa am khell xaśi khekź pirqa

$48 \mathrm{Up}$ to the present, the Chipayas call their native language Puquina. Since this is also the name of a language unrelated to Chipaya, which became extinct in the seventeenth century, some Chipayas call their language Chipaya. 
Afterwards they must also have asked another person:

"How do you live in your house?"

"I live in the rays of the sun."

"Well, you will be called Lupi now, Lupi [Sun Ray]."

Afterwards they must have sprinkled one with water.

"So now what?" he says.

"You have sprinkled me with water," he must have said.

"Ah, now you are Warachi, now [you are] Warachi [The Sprinkled One].”

Then another one, he must have been saved,

he must have been rescued,

thus [they called him] Quispe [The Saved One].

Thus in the old times the ancestors received the names.

Therefore, the surnames exist.

Now [there are]: Lázaro, Pirqa, Chinu, Lupi, Warachi.

Then they became Christians, the people.

So this is the story of Chipaya.

Text $3<\mathrm{C} 2>$ neqhśtan tshi źoñiśaqś pewkźan

qhaź qamñamt am qhuykin

werhk sïllikiś lupillar qamaritnäx ${ }^{49}$

a lupi am khekź xaśik lupi

neqhśtan ni qhaśtan wa thawqćhan

neqhśtan xaśik qhaźt

khïw warxatistaw khićhan

a xaśik warachiź am xaśik warachi

tshik hasta xaśik ni salwayćhan

nik hasta qhxispićhan ${ }^{50}$

entonces qhxispi

xalla nuź tuki timpu hasta ni awilunakak hasta nuź thü qhaychikićha

neqhśtanź ni apilliduk źelhćha

xaśik lasaru pirqa chinu lupi warachi

neqhśtan jekhchu cristianu khissiź źonakaki

niźtaqaś ni chipay kintuki

\section{Chipaya mythistory narrated by a consultant (C2) to DOBES Chipaya team members in 2005..$^{51}$}

$<\mathrm{C} 2: 1>$

I will tell of the life of our forefathers, ti werh kint'aćha ti ućhunakaź achchinakaź qamta narrated by the grandfather, maqhñillaź kint'ita narrated by our forefathers. ućhunaka achchiś kint'ita

\footnotetext{
49 Said first in Chipaya: "werhki sïllakiś" (sïlla, "sun” in Chipaya); then partly in Aymara (underlined): "lupillar qamirita nayaxa" (lupi, "sun" in Aymara). Because the priest did not understand Chipaya, the Chipayas had to use the Aymara word for sun.

50 The first time the Spanish loanword salvar is used, then the Aymara word qispi-: "tshik hasta xaśik ni salwayćhan nik hasta qhxispićhan entonces qhxispi."

${ }^{51}$ One of our main project consultants told us this version of the Chipaya origins and past. He is a Chipaya native speaker, lives mostly in the village, and is in his forties, married, with children; he is literate in Spanish and Chipaya. The story was told by him to our team for audio-recording (not spontaneously, but prepared overnight). It was then transcribed by another speaker. Later the narrator himself provided it with a literal translation into Spanish and "corrected" the Chipaya orthography; the present transcription follows the official alphabet (but with some corrections). Finally, I translated it into English, taking the narrator's own Spanish translation into account as well.
} 
We always lived on this big lake,

on the Titicaca, also on the Poopó, also on the Coipasa,

we always lived on the lake, it is said.

Thus they said:

We came from the North, it is said

from the big Lake Titicaca,

the Desaguadero, along that river we arrived at Oruro, at the lake of Oruro.

And we, one group, came from the West,

from the Lauca, as we now call the river, from along that river.

Therefore, we are on the shores of lake Coipasa, that big lake, on that shore are we. (Map 3) ućhunakki ti lagu ti chawkh qota

titicaca niźaśa ti popo niźaśa ti qhuypaś qota

qotkiśpan ućhun qaminćhu qaminćhumtaź khila

xalla nuź khiñitaćha

ućhunki uźätan thontaź khila

ni titicaca chawkh qotkiśtan

ni desaguadero xalla ni pujuranpacha niźaśa ururkiś ni urur qotkiś irantiźkitakićha

ućhunśtë tshi t'aqa taxatin thoñchikićha

ni lauka añś khiź ućhun pujun xalla ni pujuranpacha

nuźkiś qhuypaś qotkiś

ni paqh qota ni atkiś ućhun

$<\mathrm{C} 2: 2>$

Summary of following sections (very similar to the version narrated by our other consultant [Text 2]): Having come from the North and lived along the rivers and lakes, the Chipayas came to stay by the river Lauca, at a place called Capilla Perdida. Then, during the nights, they went to help build the Sabaya bell-tower (Illustration 7). They were caught by the Sabayan Aymaras. There they received Christian surnames from a priest and were baptized. Then they went away to live in different places - among them Descanso de Dios and Jilapata - until they founded Chipaya. Now they live in a very limited territory, confined by their Aymara neighbors who take away their territory:

We live in a small territory;

around us are our neighbors who have stolen our land, they have taken it from us.

That is how we live.

$<\mathrm{C} 2: 3>$

The grandparents also used to say:

We are certainly ancient people;

remains of the chullpas, say the Aymaras.

We come from the chullpas,

they [our grandparents] used to say,

having always lived before the sun, in the light of the moon. ${ }^{52}$ ućhun qamćha qolta yoqallchiś

ućhunakä muytata khiñi ućhunaka wisinunakaź źothźta yoqa qhañta

xalla niźtaź ućhun qamćha

niźaśa mathñillaki khiñitaćha

ućhunki tukita źonćhumpanćha

chullpa puchu khiñiź aymaranakaki

ućhunakki chullpikiśtan oqinćhumćha

khiñitaćha

ni thuñź tukitampan jḯkiś qamta

${ }^{52}$ Here the narrator goes back to the time of the chullpas, which, according to his own confirmation in a conversation, was before the episode of the Sabayan bell-tower and the surnames. 
They must also have gone through the

Great Flood because they lived before it.

That's what they told us.

We, [that is] our forefathers, the chullpas, lived only by the light of the moon.

There was no sun, it is said.

In that time they used to weave by the light of the moon,

by the light of the moon they used to walk around.

Now we live with the sun.

But they lived like this,

not with the sun,

only in the moonlight.

When they were living in this way, a story went round.

The sun will come out, it said,

from the West, from the South, from the East, from the North,

that's how the story went.

Then:

it will come out from the West,

this was indeed confirmed.

So they built the houses all oriented towards the East,

towards the East all the doors.

They had built them like this,

but the sun never rose from the West.

From the East rose the sun!

The sun-rays entered through the door.

Then those who were on the hill burned.

For the sun had risen with heat.

Everything must have gotten burned.

There wouldn't have been any harvest or any life.

Afterwards some of them died from hunger,

having eaten wild straw,

having eaten soft straw,

being sad.

Of those who were close to the lake, niźaśa ni chijñi mach'a watchiźlani xalla nïź tukita qamta.

xalla nuź kint'iñitaćha

ućhunki ućhun achchinaka chullpanakaki jïśkiśqaś qamñitakićha

ana thuñi źelhñitakićha

ni ora jï̌śkiś watsñi

jïśkiś oqhlayñi

xalla añś ućhunakk ti thuñźtanź qamćha

xalla niźta śaqhś ninaka qamñitakićha

ana thuñkiś

jiiśtanqaś

xalla niźtikiś qaman kintu oqhchikićha.

thuñiź thewkhźkakićha khikan

täxatan wärutan tüwantan uźätan

xalla niźta kintu oqhñitakićha

nuźkiś

täxatanź thewkhź kakiź

khissikiź oltimkiś

nuźkiś ninaka tuwañchu qhutchikama

tuwañchu śanchiśkama ninakhź qhuya qhuychikićha

ninakaź nuź qhuytan

ana śinta thuñixay taxatan thewkhźkichikićha

tuwantan thewkhźkićhi

qhuyśankiś sï luśki

nuźkiś ni kurkin khiñinakaste üjsikićha

niźaśa thuñi qhaqi thewkhźkićhan

q’ala ćhhultaqinaka üjsiźlan

ana śqalami źelhchiślan

nuźkiś ćhherqhara mayja tikhśiź ninakaki

phith lulhchi

k'iśi lulhchi

t'aqhiri

niźaśa qhaskin qotkeźu khiñinakastë 
some of them, very few,

they would have saved themselves.

Then afterwards we came [descendants of the survivors].

There are also our forefathers, grandparents [left]:

nowadays the houses of the chullpas are [still] on the hills in this area.

Those forefathers, our grandparents, they died because, living higher up, they could not get to the water. nïlla tshi qhaźulla

ninakak salwitćhan.

xalla neqhśtan oqhñiź ućhunakki

niźaśa ućhunaka achchi ephnaka źelhćha

añś chullpi qhuyanaka kurh qhuñitqi ti yoqhkiś źelhćha

nik ućhunaka achchi ephnakaćha ninakak tsewkhxapa qamku nuźpiś, ana qhaś iranti atchiźlan, nuźkiś tikhśi ninakak

$<\mathrm{C} 2: 4>$

After concluding this episode of the past, the narrator returns to the different places where his ancestors who had survived the arrival of the sun may have gone to live; some of these places have chullpa graves (Illustrations 5 and 6). The end emphasizes the Chipayas' right to live where they do, delimiting themselves from the surrounding "newcomers." The legitimation comes as much from the narrator's story itself as from his sources, the grandparents, and ancestors:

This is why we come from the chullpas.

The majority are Aymaras who have a different language...

We are the real established ones here, from before.

They are people who came. [Added by the narrator in Spanish: colonos, "colonists, settlers."]

That's what grandfather said.

This is the story then, thank you. niźtikiśtan ućhunakki chullpikiśtan oqinćhumpaćha

jila manq'aź ti yaqha tawqchiś toźanakam aymaranakak ...

ućhunćha cheqan teqhś tuki julźtaki

tinakaki thoñchi źoñinakaź

xalla nuź khiñitaź mathñillaki

tikamaqaśti kintuki sparakićha 


\section{References}

Acosta 1954 [1590]

Albó 1999

Albó and Layme 1992

Allen 1988

Amodio 1993

Anonymous 2005a

Anonymous 2005b

Ariel de Vidas 2008

Arnold 1993
José de Acosta. "Historia natural y moral de las Indias." In Obras del P. José de Acosta. Biblioteca de Autores Españoles, 73. Estudio preliminar y edición de Francisco Mateos. Madrid: Atlas, 1954. pp. 2-247. Edición digital: Alicante: Biblioteca Virtual Miguel de Cervantes, 1999. http://bib.cervantesvirtual.com/ servlet/SirveObras/12471630833470495210657/index.htm

Xavier Albó. "Entrecruzamientos lingüísticos en los rituales qullas." In $L a$ lengua de la cristianización: catequización e instrucción en lenguas amerindias de Latinoamérica / The Language of Christianisation in Latin America: Catechisation and Instruction in Amerindian Languages. Ed. by Sabine Dedenbach-Salazar Sáenz and Lindsey Crickmay. Bonner Amerikanistische Studien, 32. Centre for Indigenous American Studies and Exchange, St. Andrews, Occasional Papers, 29. Markt Schwaben: Saurwein. pp. 249-76.

Xavier Albó and Félix Layme. Literatura aymara. Antología. I. Prosa. Literaturas Amerindias, 1. La Paz: CIPCA, Hisbol, JAYMA.

Catherine J. Allen. The Hold Life Has: Coca and Cultural Identity in an Andean Community. Washington, DC: Smithsonian Institution.

Emanuele Amodio. Formas de la alteridad: Construcción y difusión de la imagen del indio americano en Europa durante el primer siglo de la conquista de América. Quito: Ediciones Abya-Yala.

Anonymous. "El alfabeto chipaya ya es oficial y entra a la escuela." La Razón, Edición Digital, 13 de octubre de 2005. http://www.bolivia.com/noticias/ autonoticias/DetalleNoticia29294.asp

Anonymous. "Joya de los Andes." Los Tiempos (Cochabamba, Bolivia). 9 de diciembre de 2005.

Anath Ariel de Vidas. "Mémoire historico-mythique et construction identitaire chez les Teenek (Huastèques) veracruzains, Mexique." In Pour une histoire souterraine des Amériques: Jeux de mémoires-Enjeux d'identités: Mélanges offerts à Nathan Wachtel. Ed. by Anath Ariel de Vidas. Paris: L'Harmattan. pp. 45-69.

Denise Y. Arnold. "Adam and Eve and the Red-Trousered Ant: History in the Southern Andes." Journal of Latin American Cultural Studies: Travesia, 2:49-83. 
Astvaldsson 2000

Barrientos Ignacio 1990

Barth 1969

Bascom 1984 [1965]

Bertonio 1984 [1612]

Betanzos 1987 [c. 1551]

Bouysse-Cassagne and Harris 1987

Burke 1991

Büttner and Condori Cruz 1984

Cieza de León 1985 [1550s]

B. Condori and Gow 1976
Astvaldur Astvaldsson, in collaboration with Félix Layme Parumani. Las voces de los wak'a. Fuentes principales del poder político aymara. CIPCA Cuadernos de Investigación, 54; Serie Jesús de Machaqa: La marka rebelde, 4. La Paz: Centro de Investigación y Promoción del Campesinado (CIPCA).

Félix Barrientos Ignacio. Chipaya: Reliquia viviente: Estudio monográfico. Chipaya and Oruro: Ed. Quelco.

Fredrik Barth. "Introduction." In Ethnic Groups and Boundaries: The Social Organization of Cultural Difference. Ed. by Fredrik Barth. Bergen and Oslo: Universitets Forlaget; London: George Allen and Unwin. pp. 9-38.

William Bascom. "The Forms of Folklore: Prose Narratives." In Sacred Narrative: Readings in the Theory of Myth. Ed. by Alan Dundes. Berkeley: University of California Press. pp. 5-29.

Ludovico Bertonio. Vocabulario de la lengua aymara. [Facsimile, based on the 1956 La Paz facsimile edition.] Cochabamba: Centro de Estudios de la Realidad Económica y Social.

Juan de Betanzos. Suma y narración de los incas. Transcripción, notas, y prólogo por María del Carmen Martín Rubio. Madrid: Atlas.

Thérèse Bouysse-Cassagne and Olivia Harris. "Pacha: En torno al pensamiento aymara." In Tres reflexiones sobre el pensamiento andino. Ed. by Thérèse Bouysse-Cassagne, Olivia Harris, Tristan Platt, and Verónica Cereceda. Biblioteca Andina. La Paz: Hisbol. pp. 11-59.

Peter Burke, ed. New Perspectives on Historical Writing. Cambridge: Polity Press.

Thomas Büttner and Dionisio Condori Cruz. Diccionario aymara-castellanoArunakan liwru: aymara-kastillanu. Puno and Lima: Proyecto Experimental de Educación Bilingüe.

Pedro de Cieza de León. Crónica del Perú: Segunda Parte [= Señorio]. Edición, prólogo y notas de Francesca Cantù. Colección Clásicos Peruanos. Lima: Academia Nacional de la Historia and Pontificia Universidad Católica del Perú.

Bernabé Condori and Rosalind Gow. Kay Pacha: Tradición oral andina. Biblioteca de la Tradición Oral Andina, 1. Cuzco: Centro de Estudios Rurales Andinos "Bartolomé de Las Casas." 
J. Condori 1982

Dedenbach-Salazar Sáenz 1994

Dedenbach-Salazar Sáenz 2007a

Dedenbach-Salazar Sáenz 2007b

Dillon and Abercrombie 1988

DOBES Project 2007

Foley 2002

Finnegan 1992

Hudson 1966

Inda C. 1988

Iriarte 2009
José Condori. "Los chullpas." In Porterie Collection 1982-85: Cond-1.

Sabine Dedenbach-Salazar Sáenz. "Texto y contexto: Releyendo las fuentes andinas a la luz de la pragmática y del discurso." América Indígena, 54, iv [Etnohistoria latinoamericana: Aportes metodológicos. Ed. by Sabine Dedenbach-Salazar and Iris Gareis], pp. 157-88.

- "The Andean Uru-Chipaya Language (State of Research and Bibliography 2007)." http://www.mpi.nl/DOBES/projects/chipaya/Chipaya $\% 20$ state $\% 20$ of $\% 20$ research $\% 20$ and $\% 20$ bibliography $\% 20 \% 28$ Dedenbach $\% 2 \mathrm{C}$ \%2019-05-07\%29.pdf

_ "Chipaya official alphabet 2005 (revised)." http://www.mpi.nl/DOBES/ projects/chipaya/Chipaya $\% 20$ alphabet $\% 20$ and $\% 20$ notes $\% 20 \% 28$ Dedenbach \%2C\%2010-05-07\%29.pdf

Mary Dillon and Thomas Abercrombie. "The Destroying Christ: An Aymara Myth of Conquest." In Rethinking History and Myth: Indigenous South American Perspectives on the Past. Ed. by Jonathan D. Hill. Urbana: University of Illinois Press. pp. 50-77.

DOBES Project. "Vocabulario chipaya: Lista de palabras chipaya-castellano." DoBeS archive $>$ Chipaya project $>$ Linguistic data $>$ Lexicon $>$ vocabulario_chipaya_20-11-2007.pdf. http://corpus1.mpi.nl/ds/imdi browser/? openpath=MPI $77915 \% 23$

John Miles Foley. How to Read an Oral Poem. Urbana: University of Illinois Press.

Ruth Finnegan. Oral Traditions and the Verbal Arts: A Guide to Research Practices. London: Routledge.

Charles Hudson. "Folk History and Ethnohistory." Ethnohistory, 13:52-70. http://www.jstor.org/stable/480778

Lorenzo Inda C. Historia de los urus: Comunidad Irohito Yanapata. Biblioteca de Autores Étnicos. La Paz: Radio San Gabriel and Hisbol.

Gregorio Iriarte. "Bolivia: ¿Un estado multinacional . . . ?” Bolpress, martes, 16 de junio de 2009. http://www.bolpress.com/art.php?Cod=2007080810 
Isbell 1997

Jemio Gonzales 1993

Keefe 1992

Libro de tasas 1575-91

López Rivas 2004

Mali 2003

Marzal 1971

Marzal 1996

McNeill 1986

Medinaceli 2003
William H. Isbell. Mummies and Mortuary Monuments: A Postprocessual Prehistory of Central Andean Social Organization. Austin: University of Texas Press.

Lucy Jemio Gonzales. Literatura oral aymara. (Archivo Oral de la Carrera de Literatura [Universidad Mayor de San Andrés]). Primer informe elaborado del proyecto "Caracterización de la literatura oral boliviana." La Paz: Universidad Mayor de San Andrés.

Susan Emley Keefe. "Ethnic Identity: The Domain of Perceptions of and Attachment to Ethnic Groups and Cultures." Human Organization, 51:35-43.

Libro de tasas. Libro donde está la cuenta y razón de las nuevas tasas que dió el excelentísimo señor don Francisco de Toledo visorrey de estos reinos a los indios de este pueblo de la ciudad de Cacares de Chuquicota y sus anexos que son San Salvador de Sacari y de Badajoz de Curaguara así a los de la corona real como doña Mayor Verdugo-aymaraes y uros-Empieza desde principio del año de mil y quinientos y setenta y cinco. Manuscript in Archivo Histórico de la Casa Moneda de Potosí (ACM), Caja Real, leg. 444. 147 folios.

Guisela López Rivas. "Etnias en extinción.” Periódico El Deber (Santa Cruz) agosto 2004. http://www.amazonia.bo/bibli/etnias-extin.pdf

Joseph Mali. Mythistory: The Making of a Modern Historiography. Chicago: University of Chicago Press.

Manuel M. Marzal. El mundo religioso de Urcos: Un estudio de antropología religiosa y de pastoral campesina de los Andes. Cusco: Instituto de Pastoral Andina.

. "The Religion of the Andean Quechua in Southern Peru." In The Indian Face of God in Latin America. Ed. by Manuel M. Marzal, Eugenio Maurer, Xavier Albó, and Bartolomeu Meliá. Trans. by Penelope R. Hall. Faith and Cultures Series. Maryknoll, NY: Orbis Books. pp. 67-118. Originally publ. as El rostro indio de Dios. Lima: Universidad Iberomericana, 1991.

William H. McNeill. "Mythistory, or Truth, Myth, History, and Historians." In his Mythistory and Other Essays. Chicago: University of Chicago Press. pp. $3-22$.

Ximena Medinaceli. ¿Nombres o apellidos? El sistema nominativo aymara, Sacaca, s. XVII. Lima: Instituto Francés de Estudios Andinos; La Paz: Instituto de Estudios Bolivianos. 
Métraux 1931

Métraux 1935a

Métraux 1935b

Métraux 1935c

Métraux 1936

Munslow 1997

National Research Council 1989

The New Jerusalem Bible 1985

Núñez del Prado Béjar 1970

Phuturi Suni 1997

Plate 1999

Platt 2002
Alfred Métraux. "Un mundo perdido: La tribu de los chipayas de Carangas." Sur (Revista trimestral publicada bajo la Dirección de Victoria Acampo, Buenos Aires) 1, iii:98-131.

. "Contribution à l'ethnographie et à la linguistique des indiens uro d’Ancoaqui (Bolivie)." Journal de la Société des Américanistes, 27:75-110. . "Les indiens uro-čipaya de Carangas: La religion." Journal de la Société des Américanistes, 27:325-415 [with illustrations].

. "La religión secreta y la mitología de los indios uro-chipaya." Revista del Instituto de Etnología de la Universidad Nacional de Tucumán, 3:7-84.

. "Les indiens uro-čipaya de Carangas: La langue uru." Journal de la Société des Américanistes, 28:337-94.

Alun Munslow. Deconstructing History. London: Routledge.

National Research Council, ed. Lost Crops of the Incas: Little-Known Plants of the Andes with Promise for Worldwide Cultivation. Washington, DC: National Academy Press. http://www.nap.edu/books/030904264X/html/

The New Jerusalem Bible. London: Darton, Longman, and Todd.

Juan V. Núñez del Prado Béjar. "El mundo sobrenatural de los quechuas del sur del Perú a través de la comunidad de Qotobamba." Allpanchis Phuturinqa, 2:57-123.

Ciprian Phuturi Suni. Tanteo puntun chaykuna valen: Las cosas valen cuando están en su punto de equilibrio. Ed. by Dario Espinoza. Lima: CHIRAPAQ, Centro de Culturas Indias.

S. Brent Plate. "Introduction: Images and Imaginings." In Imag(in)ing Otherness: Filmic Images of Living Together. Ed. by S. Brent Plate and David Jasper. New York: Oxford University Press. pp. 3-13.

Tristan Platt. "El feto agresivo: Parto, formación de la persona y mito-historia en los Andes." Estudios Atacameños (San Pedro de Atacama), 22:127-55. http://www.scielo.cl/scielo.php?script $=$ sci arttext\&pid=S0718$\underline{10432002002200008 \& \operatorname{lng}=\text { es\&nrm }=\text { iso\&tlng }=\text { es }}$ 
Porterie Collection 1982-85

E. Quispe 1985

F. Quispe 1955

M. Quispe 1984

M. Quispe 1985

Rivière 2008

Torero 2002

Tschopik 1951

Urbano 1980

Urbano 1993

Valiente 1984
Fondo Liliane Porterie Gutiérrez: Chipaya Data. Internet edition prepared by Anne Armand and Duna Troiani. Villejuif: CELIA-CNRS. http://celia.cnrs.fr/ FichExt/Fonds_Liliane/pres fonds.htm

Eduardo Quispe. "La historia tradicional de los Urus-Chipayas." In Porterie Collection 1982-85: Cahier 5.

(Fernando) O. Martín Quispe. "Copia del cuadernillo de historia tradicional de los urus de Chipaya." Khana (Revista Municipal de Arte y Letras, La Paz), 3, xixii:134-39.

Martín Quispe. "Las chullpas de Coipasa.” In Porterie Collection 1982-85: VII-7, TE.

"Historia de los chipayas." In Porterie Collection 1982-85: VIII-1, TE.

Gilles Rivière. "Amtat jan amtata ... Caciques et Mallku dans les communautés aymaras du Carangas (Bolivie)." In Pour une histoire souterraine des Amériques: Jeux de mémoires-Enjeux d'identités. Mélanges offerts à Nathan Wachtel. Ed. by Anath Ariel de Vidas. Paris: L'Harmattan. pp. 71-99.

Alfredo Torero. Idiomas de los Andes: Lingüistica e historia. Travaux de l'Institut Français d'Études Andines, 162. Lima: Institut Français d'Études Andines and Editorial Horizonte.

Harry Tschopik, Jr. The Aymara of Chucuito, Peru. 1. Magic. Anthropological Papers of the American Museum of Natural History, 44.2. New York: American Museum of Natural History.

Henrique(-Osvaldo) Urbano. "Dios Yaya, Dios Churi y Dios Espíritu: Modelos trinitarios y arqueología mental en los Andes." Journal of Latin American Lore, 6:111-27.

"Las tres edades del mundo: La idea de utopía y de historia en los Andes." In Mito y simbolismo en los Andes: La figura y la palabra. Ed. by Henrique Urbano. Estudios y Debates Regionales Andinos, 84. Cuzco: Centro de Estudios Regionales Andinos "Bartolomé de Las Casas." pp. 283-304.

Teresa Valiente. "Universo andino en el siglo XVI: Detrás de los nombres personales quechua." Indiana, 9:341-50. 
Wachtel 1990

Nathan Wachtel. Le retour des ancêtres. Les indiens Urus de Bolivie XX ${ }^{e}-X V I^{e}$ siècle: Essai d'histoire régressive. Bibliothèque des Sciences Humaines. Paris: Éditions Gallimard. 


\section{Maps}

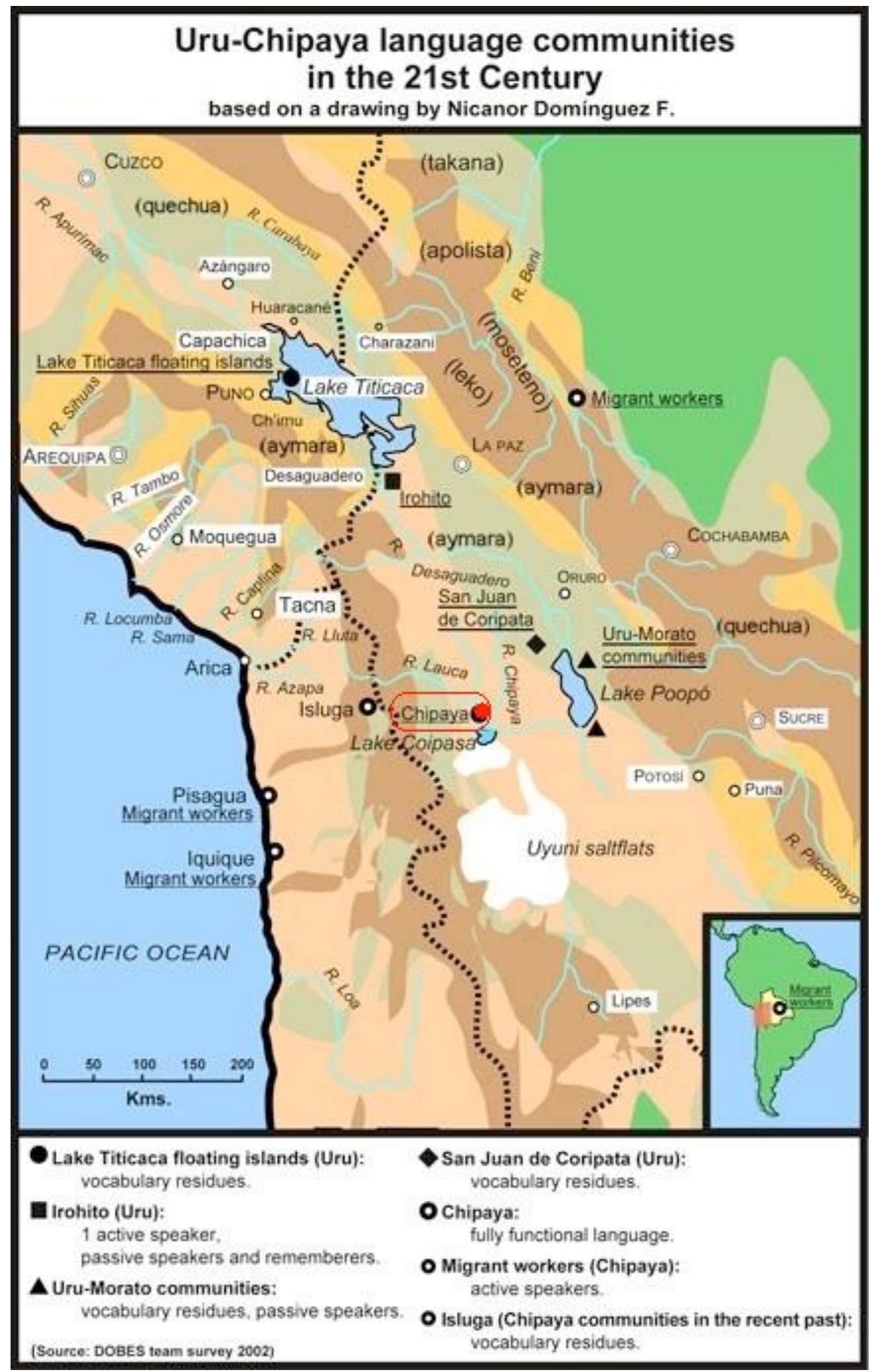

Map 1: Uru-Chipaya language communities (DOBES project, 2002, 2005-07). 


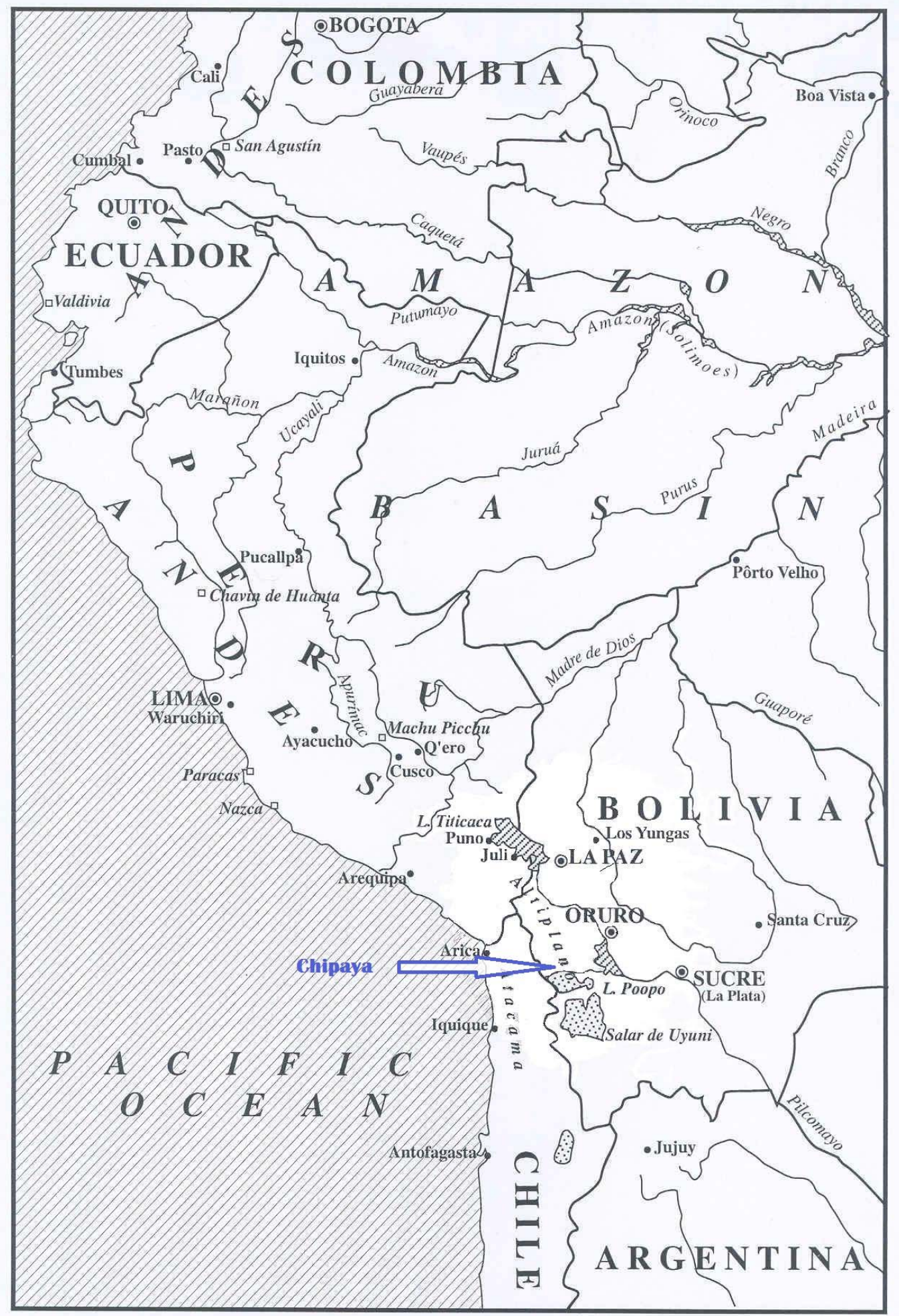

Map 2: The Central Andes and Chipaya (DOBES Project, 2002, 2005-07). 

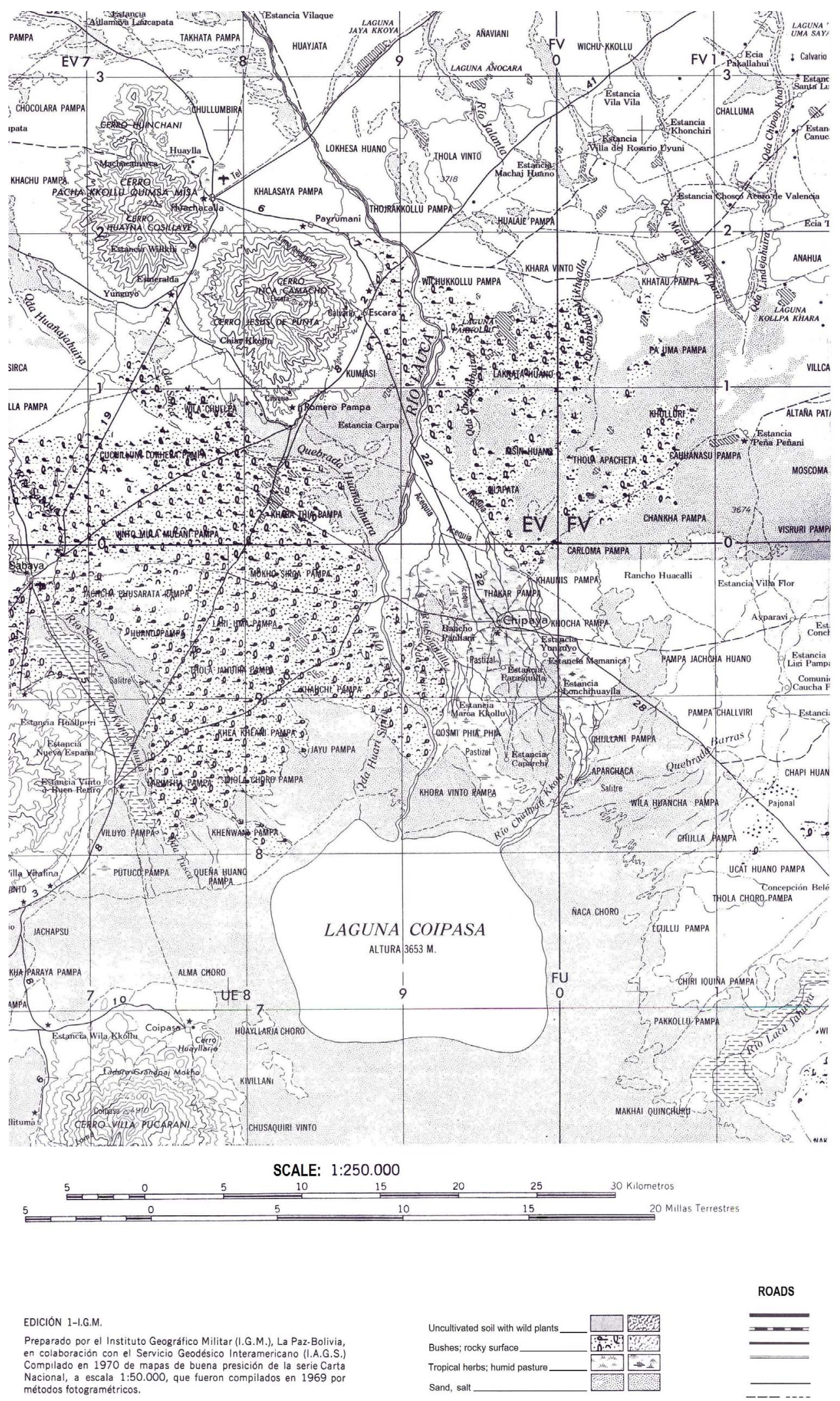

Map 3: Chipaya and surroundings. Instituto Geográfico Militar, La Paz, Bolivia, 1970, extracts from sheets SE 19-11 and SE 19-15 (based on a black-and-white photocopy). 


\section{Illustrations}

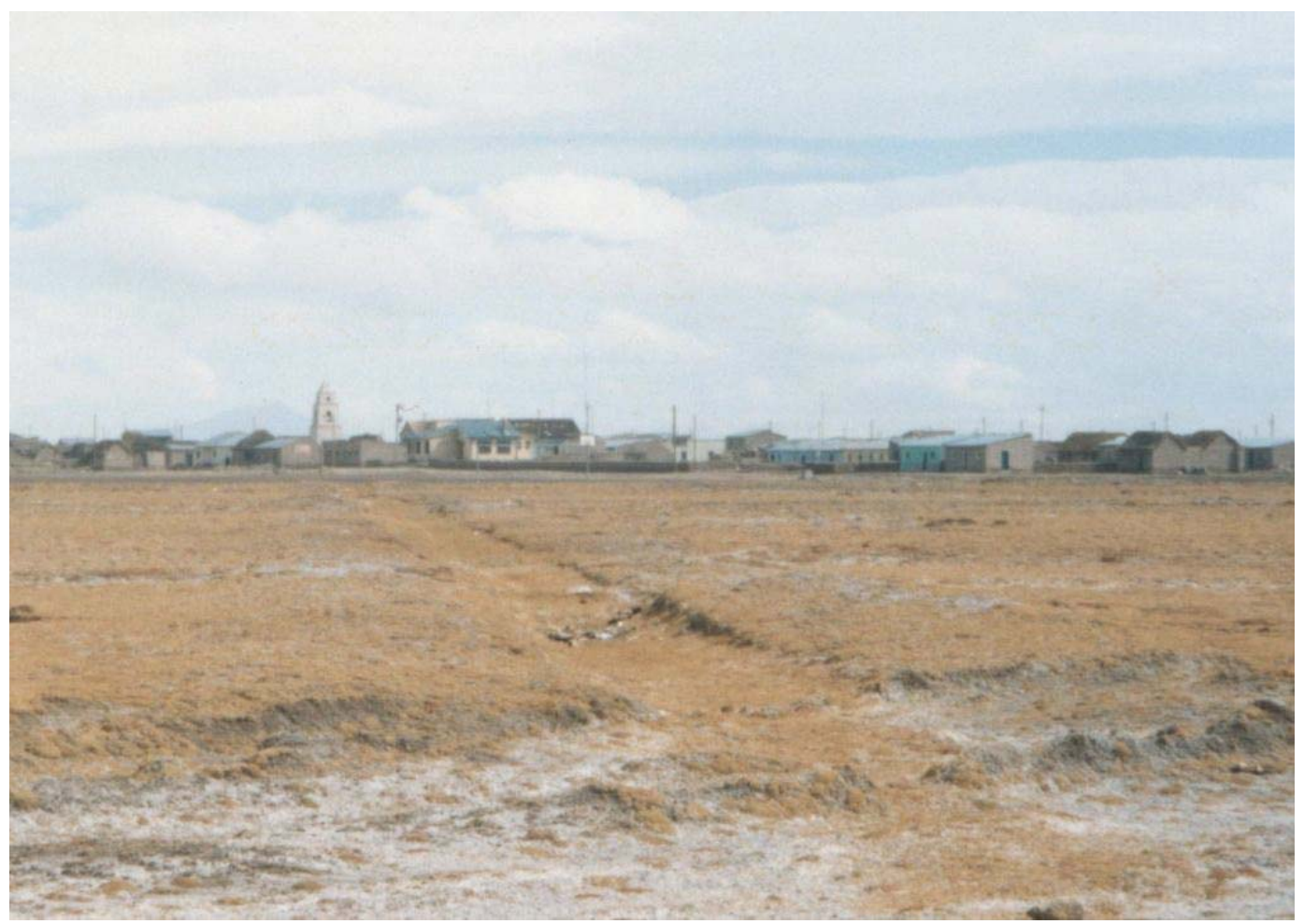

Illustration 1: Santa Ana de Chipaya (DOBES project, 2005).

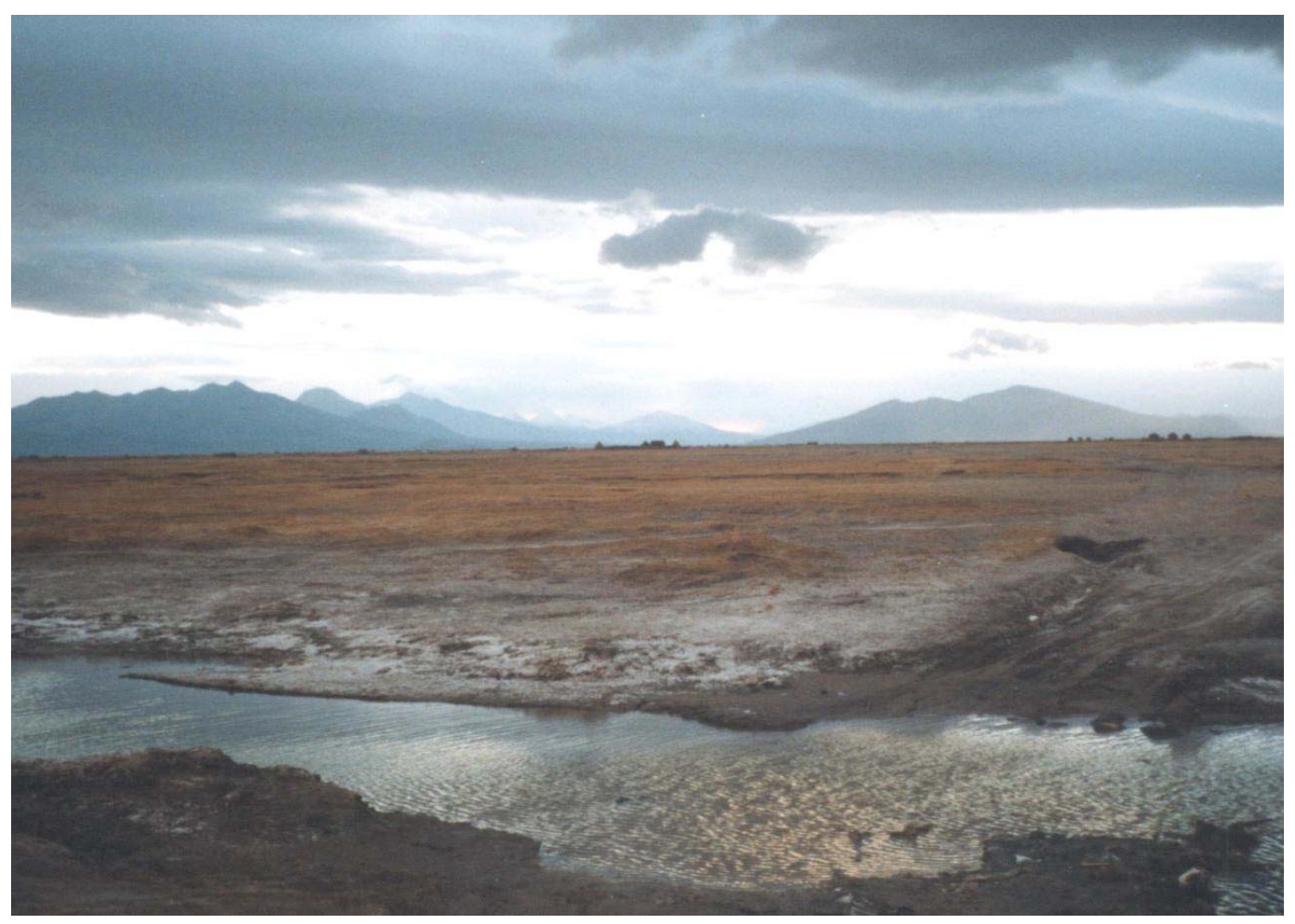

Illustration 2: View from outside the village: river, salty soil, houses in pasture-lands, and mountains (DOBES project, 2005). 


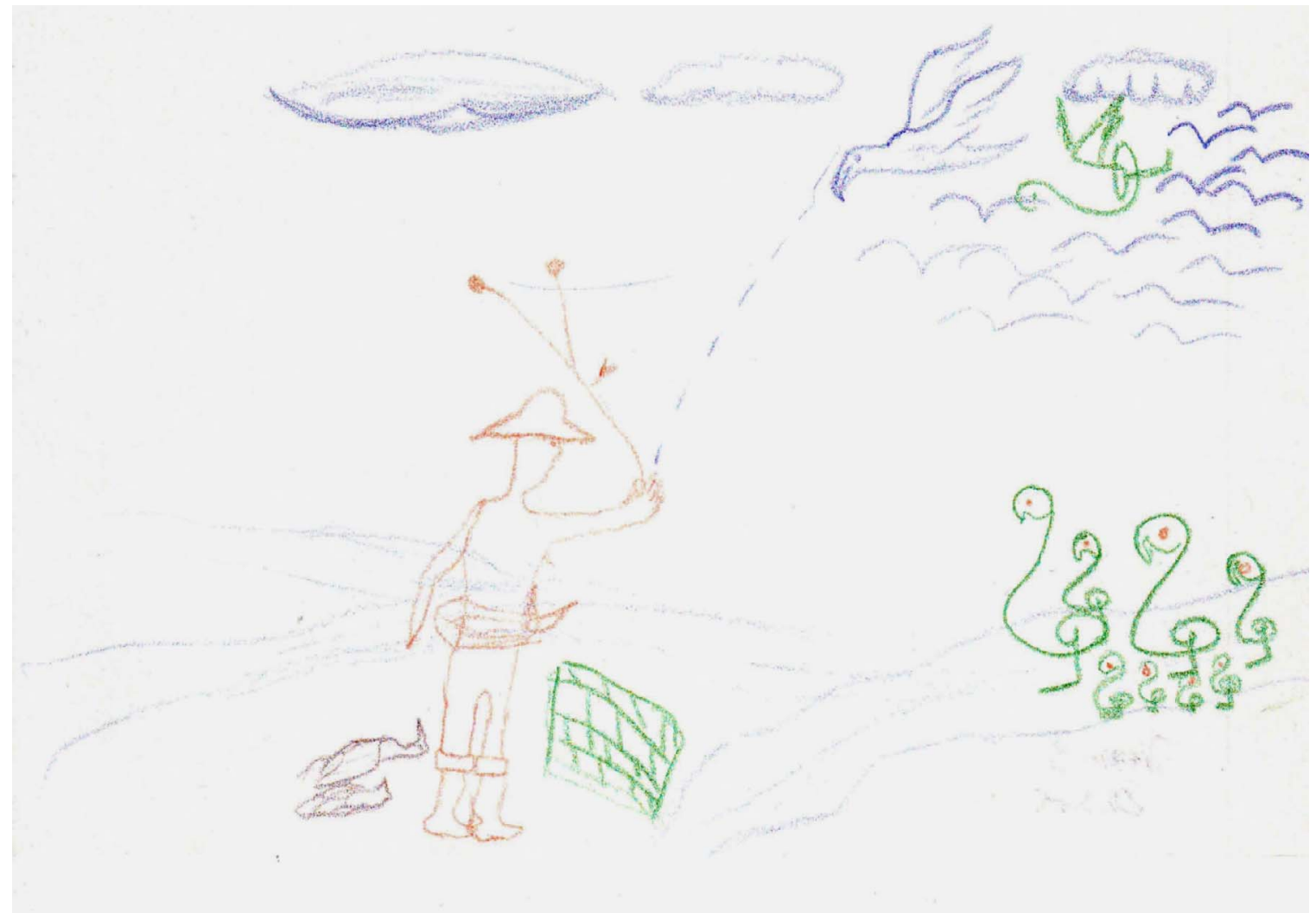

Illustration 3: Bird-hunting, drawn by a twelve-year-old boy (DOBES project, 2005).

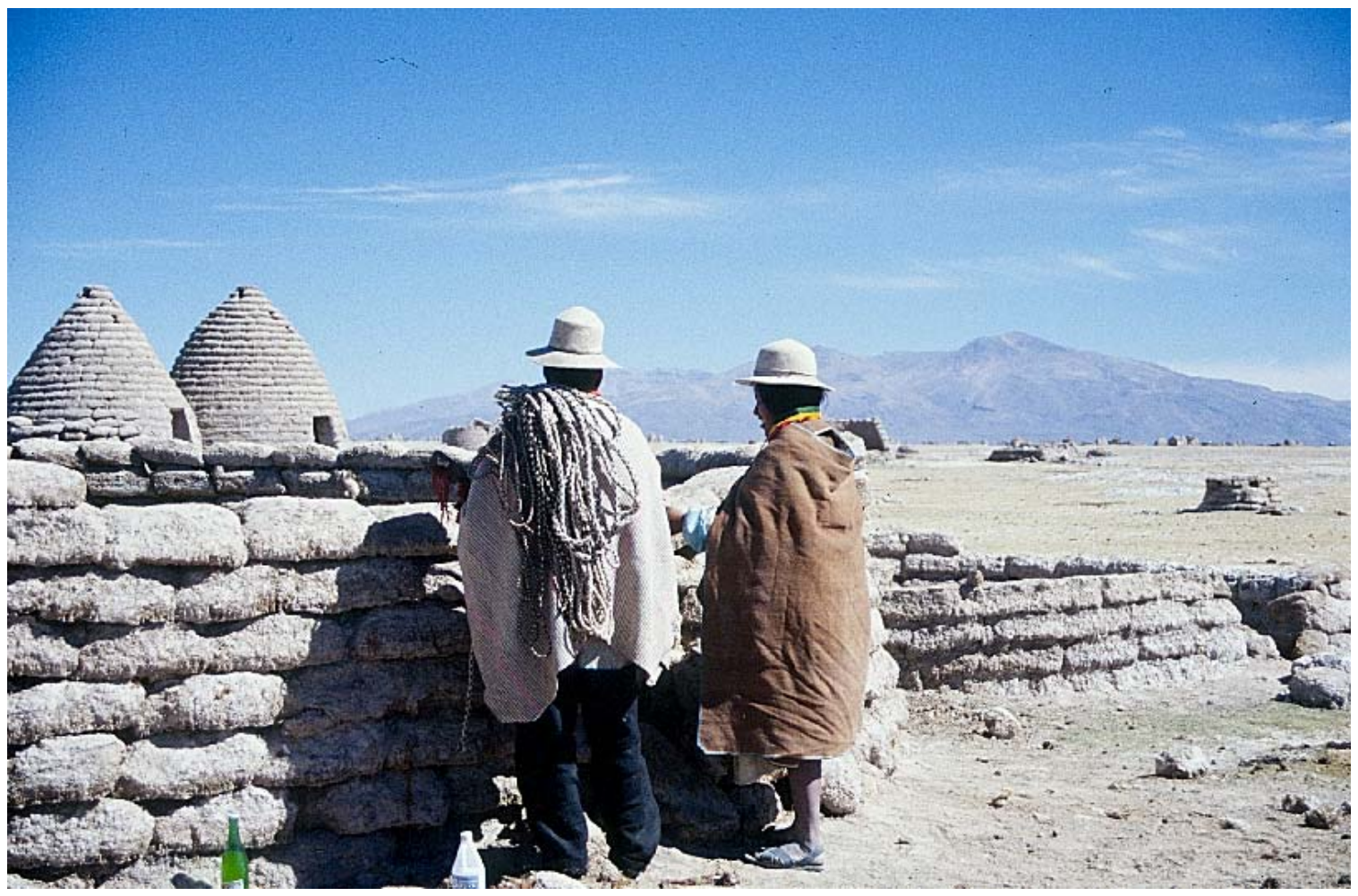

Illustration 4: Attending the pigs' castration ceremony, in the pasture-lands (DOBES project, 2002). 


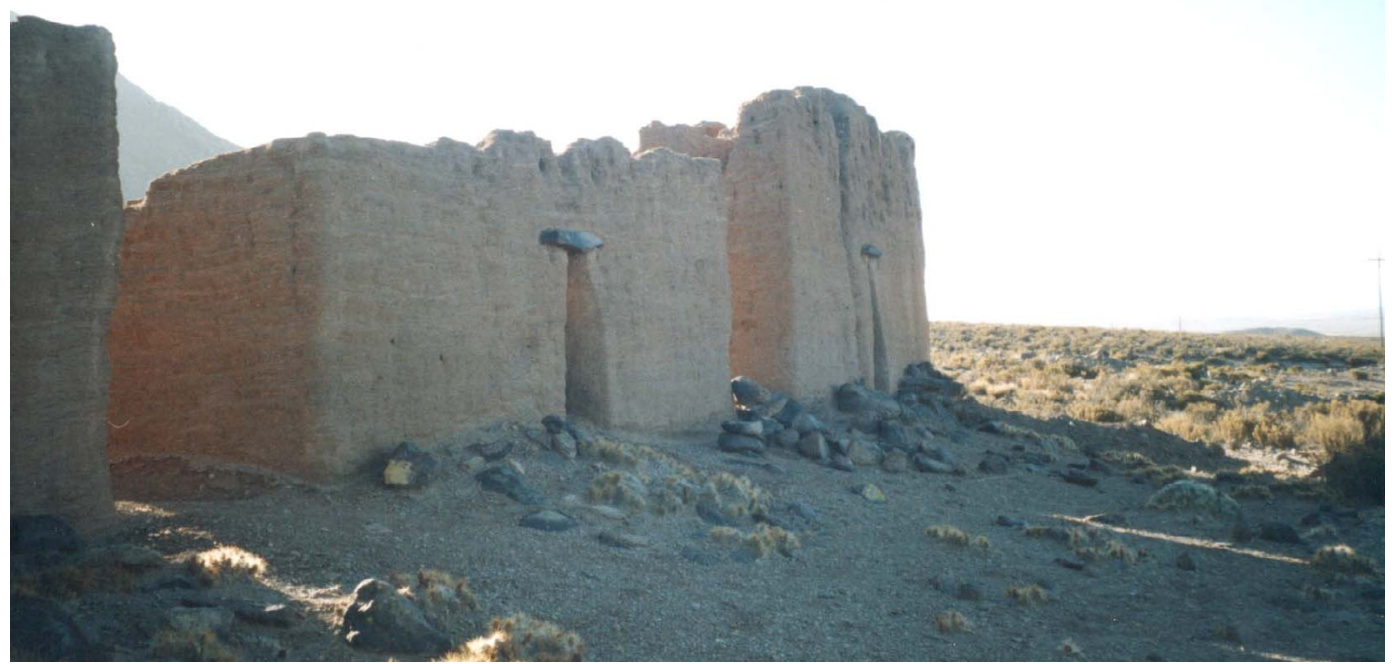

Illustration 5: Archaeological Chullpa remains near Chipaya (DOBES project, 2005).

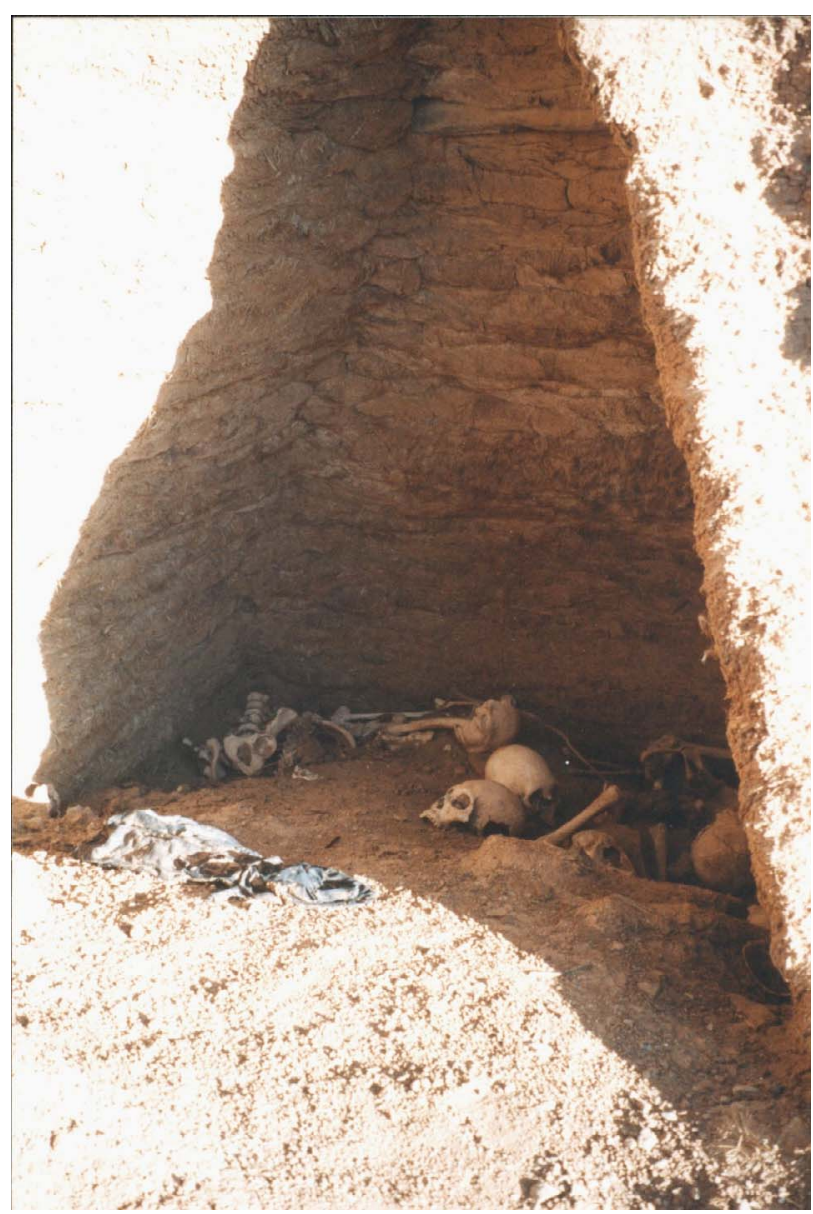

Illustration 6: Chullpa with human bones, near Chipaya (DOBES project, 2005). 


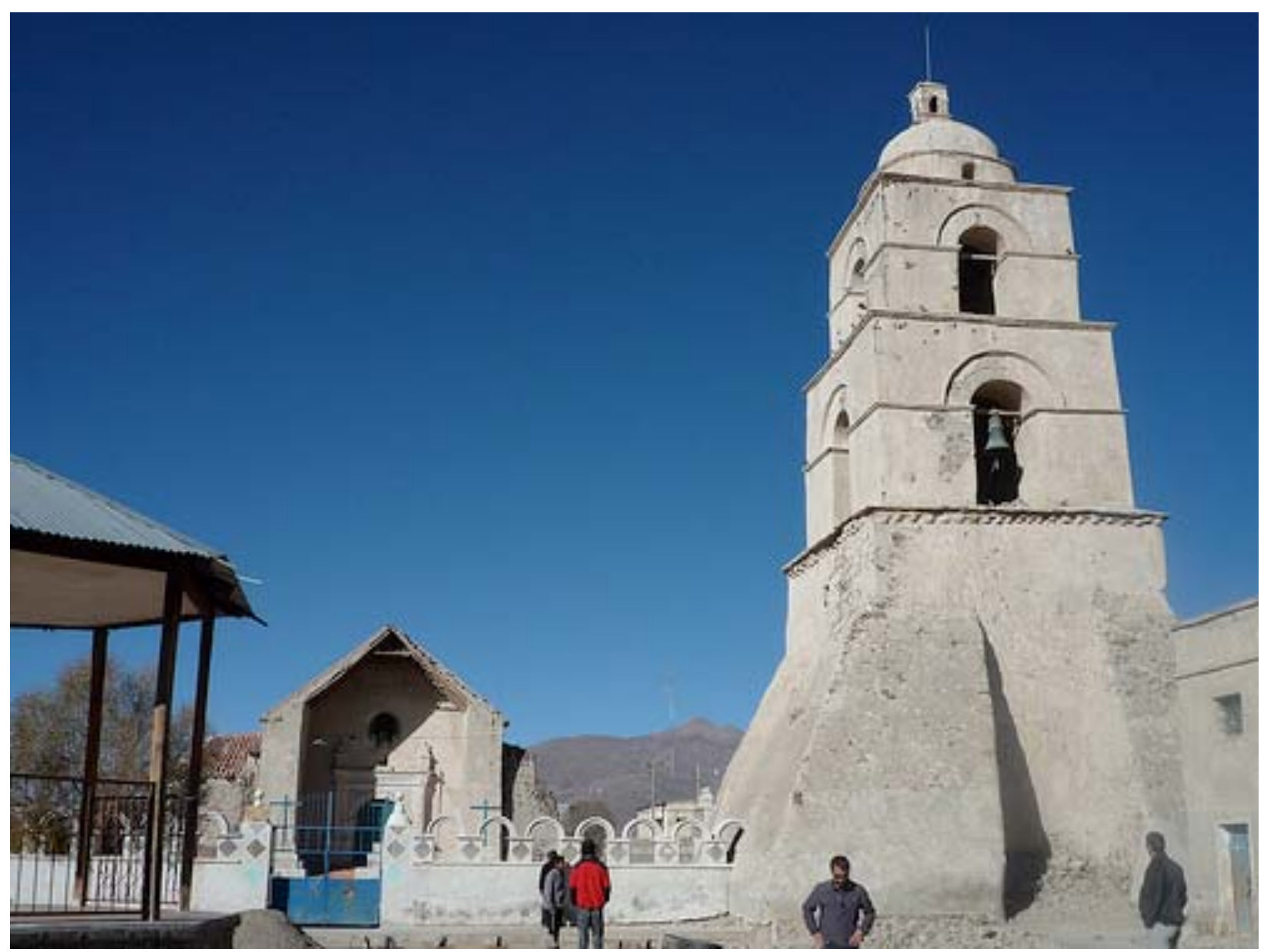

Illustration 7: The bell-tower of Sabaya church (C Pascale Soubrane, 2009). http://www.flickr.com/photos/ twiga_269/3600778465/ 
This page is intentionally left blank. 
Oral Tradition, 27/1 (2012): 231-246

\title{
Butterflies and Dragon-Eagles: Processing Epics from Southwest China
}

\author{
Mark Bender
}

\section{Introduction}

Since the 1950s large-scale government-sponsored folk literature collection projects have been carried out in China. ${ }^{1}$ These include the massive Chinese Folksong Compendium (Zhongguo geyao jicheng), a nationwide project underway since the late 1980s to collect folksongs and oral art (Feng 1999:18-19). By the year 2002, this and related projects had resulted in the collection and publication of approximately three million folk songs, nearly two million folk stories, and a whopping seven million proverbs, as well as hundreds of local dramas, prosimetric narratives, and epics (WIPO 2002:2). For the last several years, projects large and small have been underway to document so-called "intangible culture" - a whole array of oral and performing arts traditions-perceived to be threatened by modernization and globalization. Participants in this colossal effort include individuals and groups at major think tanks such as the Chinese Academy of Social Sciences, Beijing University, Beijing Normal University, Beijing Central Nationalities University, and the Institute of Intangible Culture at Sun Yat-sen University in Guangzhou. Many others are associated with provincial, prefectural, or county-level research or cultural institutes, publishing houses, and community organizations. And there are also unknown numbers of non-professional researchers and local tradition-bearers in local communities who carry out significant — though often unrecognized - documentation, research, and preservation of local folk culture.

Many such documentation efforts are being carried out in southwest China, an ecologically diverse area in the foothills of the Himalayas that is intersected by several of Asia's largest rivers. It is also the most ethnically diverse area of China. China has 56 official ethnic groups, the largest of which consists of the Han people who make up over $90 \%$ of the population. Of the 55 ethnic minority groups, over 30 live in south and southwest China-many in Guizhou, Yunnan, and Sichuan provinces. Most of these groups have many subgroups that go by various local names and in some cases have populations that spread across international borders.

1 This paper is a revised version of the Parry/Lord Lecture that the author presented on February 10, 2011, on the occasion of the 25th anniversary of the Center for Studies in Oral Tradition at the University of Missouri, Columbia. 
In this essay, I wish to explore how local individuals of two of these ethnic minority groups in southwest China are involved in what I call "processing" epic narratives of their respective ethnic groups. These individuals may wear more than one hat and include traditionbearers who know the local lore, as well as poets, scholars, and government researchers in various local and regional organizations. The "butterflies" and "dragon-eagles" in my title indicate some of the varied content of the epic traditions. Southeast Guizhou province is home to many people of the Miao ethnic group (Miaozu), also known as Hmong and by many local names. One of their myth-epics is about a butterfly known as Mai Bang, or "Butterfly Mother," who plays a major role in the creation of certain major and minor beings in Miao epic and ritual lore. After she forms in the heartwood of a sweet gum tree, she is released by moth grubs and a woodpecker, then grows into a beautiful butterfly. One day while flying down a river, foam from the tips of the waves splash her body. She soon discovers she is pregnant and later lays twelve precious eggs in a nest girded by mountains. The eggs eventually hatch out into various beings, including a dragon, a tiger, the Thunder God, and Jang Vang, the first ancestor of humans in our age - who after a great flood marries the only available woman, his sister. But this is the kind of thing that happens in myth-worlds.

The "dragon-eagles," on the other hand, are part of a creation epic from the Nuosu people, a subgroup of the large and varied Yi ethnic group (Yizu). One day a woman named Pumo Hniyyr is weaving under the eaves of her house. She suddenly spies several eagles and dragon-eagles spiraling high above. When she goes out to play with them, she is splattered by three drops of blood that fall from the sky. She soon finds out she is pregnant. Not long afterward, she gives birth to an unusual child who refuses to drink his mother's milk, sleep next to her in bed, or wear the clothes she made for him. Because of this "perverse behavior" she places him in a cave where he is raised by dragons. This is the origin of the culture-hero Zhyge Alu, who, among other things, saves the earth from an early instance of global warming by shooting down the extra suns and moons in the sky.

My title also contains the word "processing" - and by that I mean the process through which traditional texts are performed and received by local audiences. It also refers to the process by which some versions of stories are recorded, transcribed, translated, edited, and released in print or electronic format - a process the late Finnish folklorist Lauri Honko called the "folklore process." 2 The term "processing" also carries, at least for me, a sense of the sorts of compromises and distortions inherent in the manner in which the recorded texts are preserved and communicated to new audiences. Just as natural foods or textiles are processed and marketed into products for consumption by target audiences, so too are items of oral literature. We now have genetically engineered corn, soybeans, and hemp. A box of "heart healthy" oat cereal may contain a whole list of additives, supplements, and fillers - sometimes mimicking original, truly wholesome products and directed at consumers open to healthy, natural, and eco-friendly foods. But we increasingly know it is necessary to read the fine print - just as Lauri Honko reminded us

\footnotetext{
2 See Honko 2010:15-35 for an in-depth discussion of the process of performance and textualization of oral epics. The term "processing" also appears in the title of an edited volume of folklore studies entitled Folklore Processed: In Honour of Lauri Honko on His 60th Birthday 6th March 1992 (Kvideland 2000).
} 
that it is necessary to understand the process of the "processing" of oral texts that occurs behind the book or website banner. ${ }^{3}$

So what about China? What is the background of their collecting and processing efforts? As noted, since the 1950s efforts were made to collect, edit, publish — and now sustain —a great number of local oral and oral-connected traditions of songs, stories, drama, and epic. It has not always been easy. Such efforts were severely interrupted in the late 1950s and throughout much of the 1960s and 1970s because of various extreme political movements. These movements began with the anti-intellectual "Anti-Rightist" movement of the late 1950s and culminated in the Cultural Revolution between 1966 and 1976, a period of ten years in which traditional folk culture, collecting, and research efforts were under direct assault. Since the late 1970s and especially since the early 1980s, as China has shifted course, collecting efforts - employing both older and newer methods of documentation have increased exponentially. Stimulated by more open policies and increased wealth due to economic reforms, folk festivals and temple fairs bustle in some places, often in concert with the ethnic tourist trade. There are also revived or new contexts for many styles of oral performance; a few traditions have even gained national or global attention in contexts hard to imagine only a few years ago.

That said, many local oral traditions are threatened, endangered, or moribund. This is especially true of some styles of folksong and epic singing performances that may soon survive only in bits and pieces in newly emerging contexts such as Chinese versions of YouTube, in digitized museum displays, or in locally made and distributed CDs or flash drives - many of which are now common in various rural areas. The number of folk singers among ethnic minority groups in parts of western Guizhou, for instance, is in rapid decline for those under age 40. In some Yi areas in northern Yunnan, there is no one able to sing or read the traditional funeral lyrics. In some places where ethnic minority languages or local dialects of Han Chinese are spoken, native tongues are replaced by Standard Chinese and whole song repertoires disappear. One example is the imakan (yimakan) narrative tradition of China's smallest official ethnic group, the Hezhen of northeast China who number just over 4,600. According to Yu Xiaofei, who for years has been deeply involved in processing the tradition, Hezhen is now spoken by only a handful of people over $50 .{ }^{4}$ Presently, no one can recite the epics in the Hezhen language.

\section{Case Studies}

I would like to introduce two different scenarios for two different reasons. The first involves an individual who has persevered against long odds for over 60 years in his efforts to

3 This interest in the process of creation and performance was a concern that engaged Milman Parry and Albert Lord, evidenced by their drawing attention to the backgrounds of the singers and the contexts of performances. It is also a concern that prompted Lauri Honko to edit the Textualization of Oral Epics (2010) in which fieldworkers explain how they did their documentation. See also Lord 2000:13-14 and Foley 1995:27-28.

${ }^{4}$ Originally from northeast China, Professor Yu Xiaofei teaches at Nihon University in Tokyo, Japan. She has spent many years documenting the last performers of the Hezhen oral narrative known as imakan (yimakan). See Yu 2005:14-17. 
preserve the Butterfly Mother epics. This example will also throw light on attitudes about processing epics in China and some of the rationales behind the methods. In the second case I will describe a visit to an upland village that formed part of my experience working with an epic tradition-bearer and an ethnic poet. On the one hand, we glimpse the life of the local-tradition bearer in his mountain home. On the other, we see how researchers formally and informally obtain knowledge of both tangible and intangible local knowledge that is so crucial in interpreting the imaginative "story worlds" of the epics - that is, the sort of knowledge that John Miles Foley recognized as often being crucial to understanding the "traditional referentiality" of cultural imagery in oral traditions. ${ }^{5}$

\section{The Butterfly Mother Project}

My first case centers on a project pursued for over fifty years by Jin Dan (Jen Dang), a Miao (Hmong) epic singer, ethnographer, and scholar. Now in his eighties, Jin is from mountainous Guizhou province in southwest China.

The Miao ethnic group numbers over eight million members. Names for the dozens of subgroups vary widely, as do local customs and dialects. In southeast Guizhou province, there is a Miao oral performance tradition that involves the antiphonal singing of myth epics and is known as "ancient songs" (hxak lul hxak ghot), though it is now difficult to observe full-blown performances. The content of the narratives relates the creation and separation of heaven and earth; the creation of suns, moons, and stars by early gods; the shooting down of the extra heavenly bodies by a hero (as we saw in the Yi myth of Zhyge Alu); the birth of the ancestors of humans and other beings that hatch from Butterfly Mother's eggs; and a great flood that acts as a precursor to the present age. Several of these motifs appear frequently in the mythic and epic lore of China and Eastern Asia. ${ }^{6}$

Since the early 1980s, several versions of the epics have been published in both Standard Chinese and bilingual Miao/Chinese volumes. The published version with which I am most familiar was initially collected in the 1950s by researchers that included Jin Dan and the late ethnolinguist Ma Xueliang. After working on and off with Jin Dan from about 1985, in 2006 I published an English version of this text in the United States under the title Butterfly Mother: Miao (Hmong) Creation Epics from Guizhou, China. A few lines of the English translation give some idea of the style and content of the epic. As Butterfly Mother (Bangx) emerges from her cocoon, she combs her hair and primps herself with her many hands (Jin et al. 2012:353):

When Butterfly was born, her face was mottled;

Her tangled locks were like balls of hemp.

What did she use to comb her hair?

\footnotetext{
5 For discussions of "traditional referentiality" in regard to Homeric epic, see Foley 1999:xiv, 201-40 and Foley 1995:42-47.

6 For further information on myth-epics of several ethnic groups in China, see Yang et al. 2005 and Schipper et al. 2011.
} 
What did she use to wash her face?

Her hands were slim and fingernails were sharp,

She used them to comb her hair,

So her hair was neat and clean.

She used misty rain water to wash her face....

In late 2008, much to my surprise, I was asked by Jin Dan's son Wu Yiwen to participate in a project with The Nationalities Publishing House in Guizhou (Guizhou minzu chubanshe), which had agreed to publish a tri-lingual version of the epics in Miao, Chinese, and English. ${ }^{7}$ This new version, which is a sort of intervention in the interests of preservation, is being made in the face of a clear decline in singers and the perceived need for a complete, master version in the Miao Romanized script, a script created and refined beginning in the 1950s. In the process of again working with Jin Dan and his children, not only did I gain more first-hand insight into how oral literature is processed in China today, but I also learned much more about Jin Dan's personal relation to the text.

\title{
Creating a "Collective" Version
}

In the Afterword in the forthcoming new edition (Jin et al. 2012:621), Jin states that:

\begin{abstract}
The format and content of this book is essentially similar to the 1983 Chinese version. However, in the twenty-plus years since then, we have still continued to collect and transcribe new material. Every singer has a slightly different version, and whenever we came across vivid material that could be used, we added it in. We also changed the poetic meter of the Chinese translation to lines containing seven characters, and added some explanatory notes as well. ${ }^{8}$
\end{abstract}

The quote sums up what is still a very common approach to oral literature today in China. In speaking with folklore collectors and editors, I have often heard the term wanzheng (完整), or "complete," when referring to the record of a particular item of folklore - in particular, a longer song or story. Although the appreciation of multiple versions gathered in specific performance contexts has a growing place in folklore circles in China, there is still a strong tradition of creating "complete" versions of a given song cycle or story tradition that will serve as part of an ethnic group's official tradition of oral literature. These versions usually combine several versions collected from a number of singers. In some cases the participating singers and elders

7 The volume will be published in late 2012 under the title Hxak Hlieb: Miaozu shishi (Hmong Oral Epics). The tri-lingual translation is being offered for those-probably a majority of potential readers-not able to follow the often difficult or obscure wording of the register of Miao used to sing the epics, and to make the text available (in Chinese and English) to the widest audience possible in local and non-local audiences. There is also concern over the introduction of a competing myth narrative in official discourse on Miao origins that stresses the common origin of ancient Miao with other Chinese tribes, rather than the hatching of the local ancestors from a butterfly's eggs.

${ }^{8}$ Levi Gibbs, a Ph.D. candidate at Ohio State and an expert on Chinese folksongs, aided in the translation of this quote and some of the other supporting matter in the forthcoming tri-lingual version (Jin et al. 2012). 
may be involved with editors in the negotiations concerning the makeup of the final master version. In theory, such master texts - which might be best described as "collective versions"are intended to reflect and preserve the richness and completeness of the tradition in a format that can be read and appreciated to its fullest by present or future generations without access to multiple live versions. In the past, much more so than is usual now, this stage of editing also allowed for selection or omission of content deemed crude, backward, divisive, or otherwise taboo.

\section{Jin Dan and the Epic Text}

Whether one acknowledges a place for the "collective version" approach or not, Jin Dan's epic relation to the epics gives insight into how such texts have been processed. The following is an outline of his story. As Jin Dan explains in his Afterword (Jin et al. 2012), in 1952 the famous ethnolinguist Ma Xueliang from the Central Nationalities Institute (now University) in Beijing organized a group of ethnographers, including Tai Changhou, to record Miao oral literature in southeast Guizhou. Jin Dan was hospitalized at the time but later joined the project in 1954 as an editor of the collected materials. He decided to stress the Miao epics, a tradition he was intimately familiar with, having often participated in the singing himself. He later gathered more texts from oral sources before the work was scheduled for publication. However, the project was shelved during the Anti-Rightist campaign in 1957-a political movement aimed at intellectuals. This event resulted in Jin Dan being sent to a tree farm to work for several years, and the original manuscript was lost during this period.

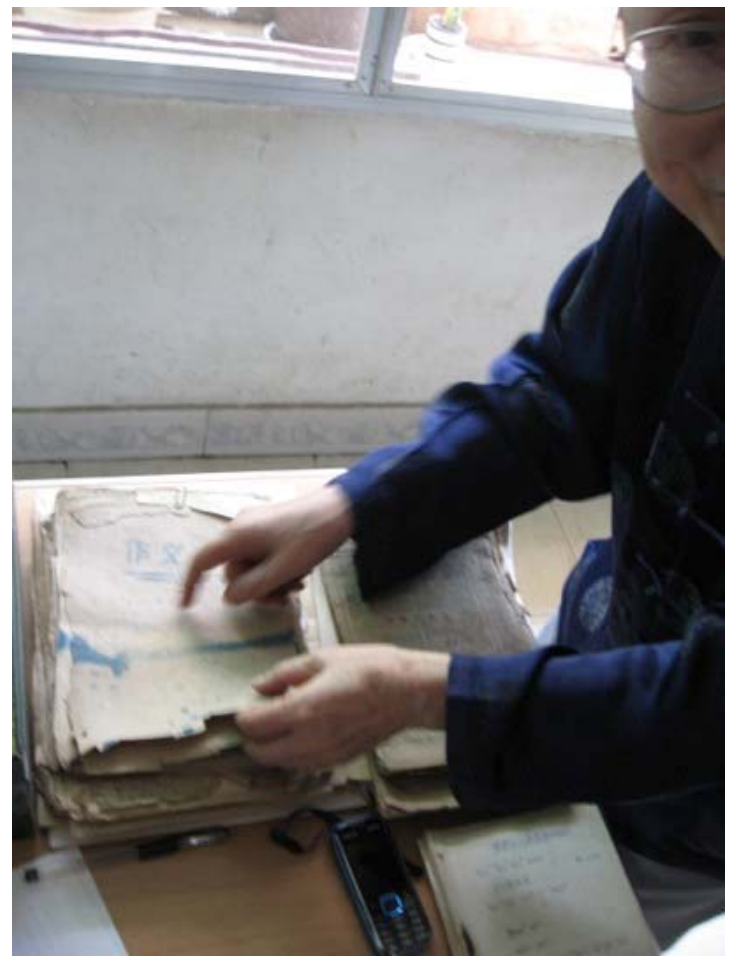

Image 1: Jin Dan pointing to his signature on a manuscript from the $1950 \mathrm{~s}$.

The project started up again in 1962 when

Jin Dan contacted Professor Ma about re-collecting the work during a period of slackening political winds. At this time Jin Dan was able to get some notes about the content of the epics from Tai Changhou's widow. This phase of re-collection and editing was taken under the most difficult conditions. At times he and a younger brother (whom he recruited for the task) collected parts of the epics when running into singers during stints as garbage collectors. While still living at the tree farm, his efforts were again interrupted by the Cultural Revolution (1966-1976) which threw the whole country, not to mention folklore collecting efforts, into chaos. It was only in the late 1970s that the project picked up again-which of course meant more collection, recollection, and editing. 
Until the summer of 2010, when I spent a week in Guiyang revising the English translation, I was only vaguely aware of Jin Dan's story. However, many things came into sharp focus on the last day when I told his daughter $\mathrm{Wu}$ Yifang that I would like to shoot some video footage of her father talking about anything he liked. The next day at noon, just before a sumptuous lunch of Miao-style sour vegetables, fish, and corn gruel, Jin Dan invited me to bring my cameras to his desk. He spoke for about twenty minutes, recounting his interaction with the epics over a span of more than 50 years - repeating and clarifying much of what he had written in his Afterword (Jin et al. 2012). He then turned to several piles of manuscripts that lay right beside the boxes of index cards he was using to carry out his latest project - a dictionary of the words in the linguistic register used in the epic singing.

The manuscripts in the piles were all written in his own hand, and each one had his signature and a date. Some were from the earliest phase of the collecting, some from the period in the late 1950s and the early 1960s. These, he explained, were manuscripts that had been turned over for "safe-keeping" to various cultural units that oversaw him during the political movements. He had been ordered to sign and date the cover pages himself so that no one else could be implicated in handling these documents that reflected "a feudal mentality" and "superstition." But Jin Dan counted himself lucky on some accounts; he had received the texts back at the end of the troubled era and they formed the basis for not only the revival of the epic project, but also other undertakings such as the dictionary and books by Wu Yiwen. Additionally, they had led to eventual visits by his daughter Wu Yifang to the annual American Folklore Society meeting in 2006 and also The Ohio State University.

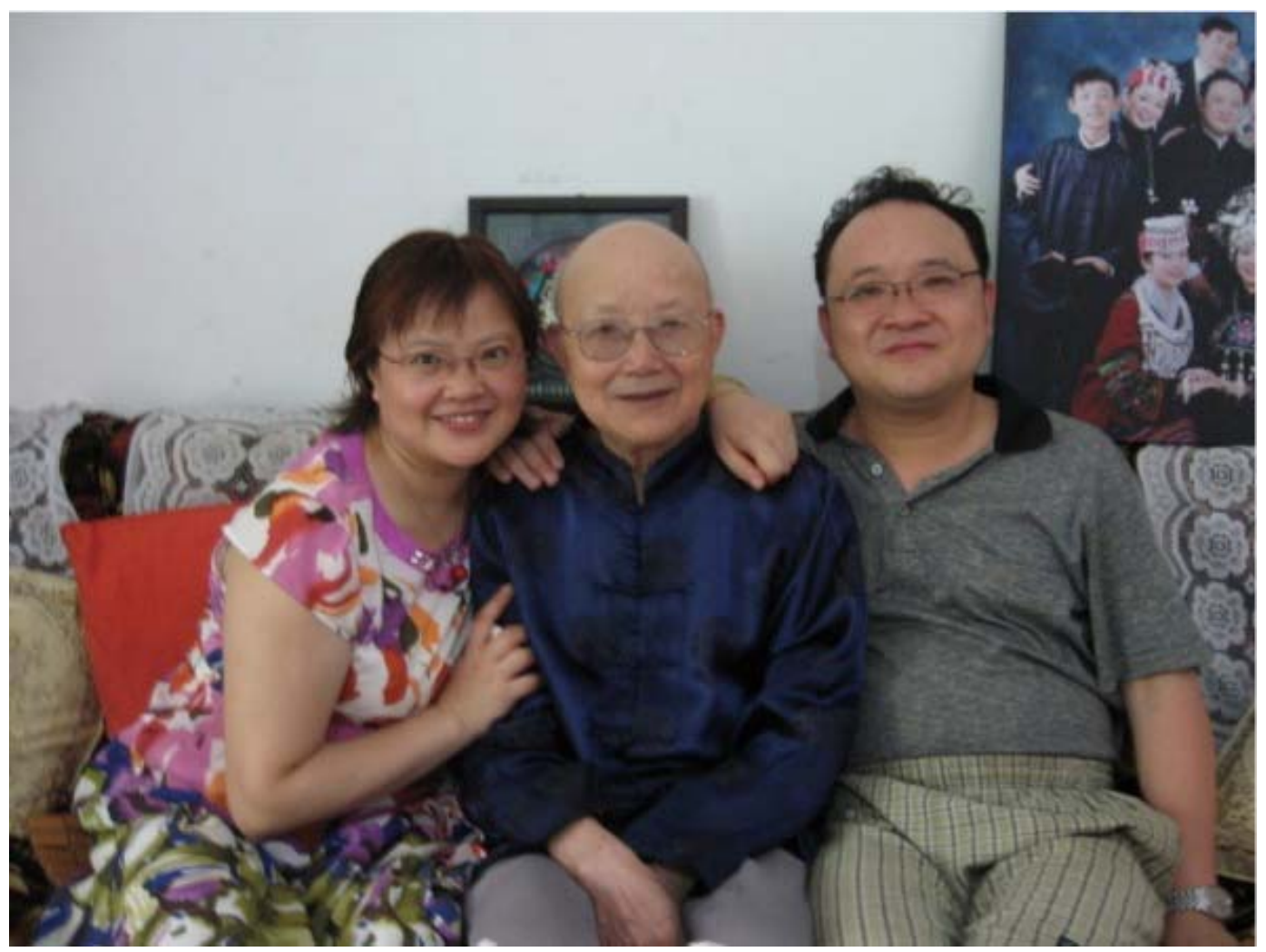

Image 2: Jin Dan with his daughter, Wu Yifang, and his son, Wu Yiwen. 
With echoes of the story of Jin Dan and the Miao epic project thus in mind, I would like now to turn toward another set of individuals - this time of the Yi ethnic group from southern Sichuan province-with whom I am working on a project to translate a version of an oralconnected written epic belonging to a local tradition-bearer.

\section{Dragon-Eagles}

The Yi ethnic group has over 80 subgroups with a total population of over seven million. Most live in the mountains of southwest China in the provinces of Yunnan, Sichuan, Guizhou, and Guangxi. The largest subgroup, known as the Nuosu, numbers about two million, and its members live mostly in southern Sichuan. Known to European explorers in the pre-1949 era as the "independent Lolos" and infamous for what has been described as a "slave society," the group once controlled an area of southern Sichuan known as the Greater and Lesser Cool Mountains (Da Liangshan and Xiao Liangshan). The Nuosu have received increasing attention due in large part to the efforts of two highly educated and well-positioned sisters - Bamo Ayi and Bamo Qubumo, often known as the Bamo sisters - and foreign researchers such as Thomas Heberer and Stevan Harrell. ${ }^{9}$ Another very active promoter of Nuosu cultural preservation is poet and scholar Aku Wuwu (See Aku 2005, Aku and Bender 2006).

$\mathrm{Aku}$ Wuwu - also known by his Chinese name Luo Qingchun-is a poet of the Nuosu branch of the Yi ethnic group. He is presently dean of the Yi Studies Institute at the Southwest University for Nationalities in Chengdu, Sichuan province. In 2003 I was introduced to Aku by Bamo Ayi, one of the Bamo sisters. I was asked to work with Aku to translate his poetry into English; he is the only Yi poet who has created a corpus of poems in the modern Nuosu script of 819 graphs based on graphs drawn from the ancient Yi writing system still in use by priests known as bimo. To translate his poems into English, we developed a laborious translation technique that involves triangulation between the Nuosu script, Standard Chinese (which we both speak as a common language), and English. I soon discovered that Aku's poetry is densely packed with imagery, stylistic features, and folk ideas from traditional Yi ritual, oral art, and the centuries-old traditions of Yi writing safeguarded by the bimo priests.

Aku's most famous poem is "Calling Back the Soul of Zhyge Alu" ("Alu yyr ku"), in which he calls on the Nuosu to regain a sense of self by evoking the spirit of the culture-hero Zhyge Alu - who, as noted, was raised by dragons. Aku and I soon decided to assemble a multilingual version of the Nuosu epic Hnewo teyy (The Book of Origins), an epic of creation and origins. Although a few Chinese translations were available, we decided to attempt to find a version written in Yi from among the folk.

Drawing on his vast web of connections in the Greater Cool Mountains, Aku eventually located a willing tradition-bearer with a handwritten copy of the text. Most texts outside museums today are in the hands of bimo priests. The owner of this text, however, was known as a ndeggu, or "wise man"- a man who arbitrated disputes in the community and was a source of

9 The following works are representative of recent literature on the Nuosu: Heberer 2007, Harrell et al. 2007, Harrell 2002, Harrell et al. 2000. 
many sorts of traditional knowledge. His name was Jjivo Zoqu, and in the summer of 2006 we met in a government office in a tiny town in Xide county-where he had walked eight hours down the mountain. We were accompanied by an elderly bimo who had also come down to add spiritual sanction to our interaction with the text. While we managed to rough out and revise a translation over the next few summers, it was not until the summer of 2009 that I finally visited Jjivo in his upland village.

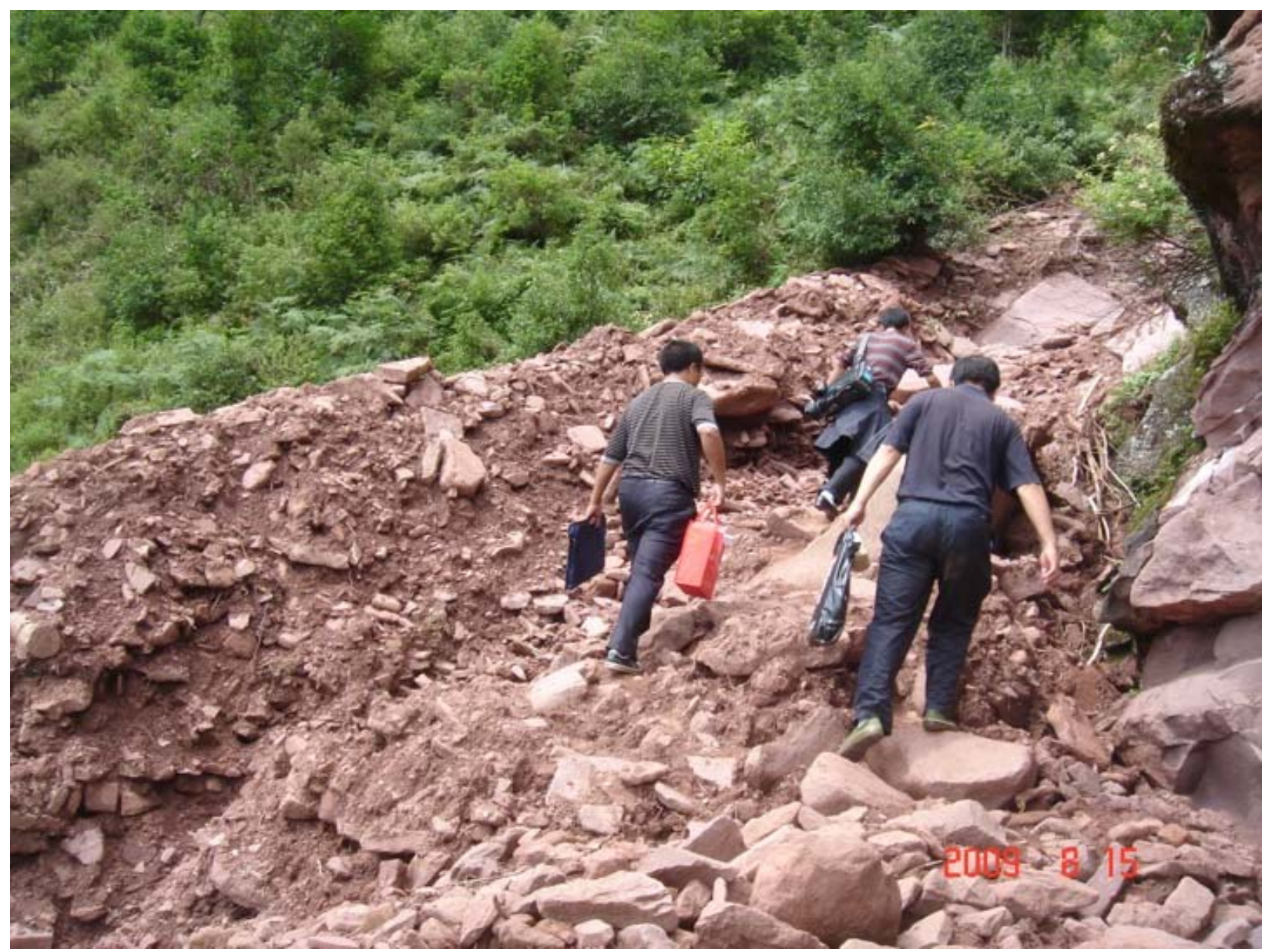

Image 3: Climbing a landslide on the way to Jjivo Zoqu's homestead.

What follows ${ }^{10}$ are a few passages from my field notes that shed some light on how the experiences of that day influenced our process of translating and re-imagining the epic world:

August 09,2009 . The lurching Jeep finally came to a halt on the stony red clay road. Our heads and necks still intact, we climbed out of the vehicle and took stock of what we had to carry into the gorge above. Two large bottles of gift-boxed liquor, a video-camera, several digital still cameras, two large bags of candy, and a few plastic bottles of water were our pack. The money for the feast gift $\left(k a^{\prime} b b a\right)$ didn't weigh much but was also taken into account. As the Jeep turned

10 These notes, based in part on notes taken on-site, were written on August 12-13, 2011, in Chendgu, Sichuan province, China. This is their first publication. 
around and started back down the mountain, we set off at a steady clip up the road, taking short cuts up the steep, slippery banks at each turn. After a few minutes, we reached a large bend that turned right into the distance. High above, directly in front and across a small, steep valley, we could make out a narrow trail that headed left uphill. . . This was the "shortcut," taken due to a landslide on the main road. From here on the going for the next two hours would be smooth.

Looking back over the wide valley, fields and forests seemed a far away patchwork. A few earthen houses dotted the hills, and far in the distance another range of low mountains rose above a tributary of the Anning River on its way towards the town of Mishi in Xide County. As we continued up the grade, raw pink and grey cliff sides came into view spliced with small clumps of scraggly pines and firs. Jjivo's nephew told of how eagles nested there and could still be seen at the right moments....

At several points Jjivo's nephew stopped and pointed out rhododendrons, pine trees, and other plants that figure in the Book of Origins: "See how the heads of these plants bend downZhyge Alu first stood on them to try and shoot down the suns and moons- but they could not hold him. So today they still bow their heads...."

Jjivo's family and male representatives from all the local families stood at the hilltop eagerly waiting our ascent. An earthen wall surrounded the house and courtyard, which was lined with animal cribs made of tightly fitted logs and earth. Outside were a chicken crib, and a small log building for tools and storage. The buckwheat harvest was on and most of the locals were busy getting in the crop before it dropped its seeds, losing them into the dirt. ...

Entering the courtyard through the low gate, we were immediately escorted inside a door in the main building to our right. As is typical of many rural Yi homes, there were no windows, and light filtered into the dim room from two square holes high in the eaves. Several large wooden chests lined the walls. We were led over to a row of tiny stools set on the hard-packed dirt floor to the right of the fire pit in which a large wok filled with boiling broth bubbled on an iron trivet set above the coals. According to the epic, it was in such a fire pit that the Apu yoqo bird flew and singed its tail feathers when it stole the secret of speech from the Sky God. Although the seat of the hosts is usually beside a house post near the fire, Jjivo sat opposite us with his family and we chatted as women carried in large wooden bowls, lathed from mountain birch and painted with lacquer and red, black, and yellow designs. ...

Taking up our wooden spoons (ichy) — the ones with the handles affixed sideways so as to produce a kind of scoop - we were encouraged to dig into the bowls mounded with gummy buckwheat cakes, chunks of pork and goat meat on the bones, a pot of braised intestines, and a soup of reconstituted voma turnip greens, white soybean paste, and sliced potatoes. There were also whole yellow and purple potatoes of various sizes, which in accord with protocol had to be gently peeled before eating. It was still a bit early for boiled corn, usually eaten on the cob. With a flick of the wrist, the spoons skimmed aside the floating layer of fat as we scooped the contents out into our mouths - taking care not to dribble into other bowls. Pieces of meat and potato, once taken in hand, were carefully examined for a few moments, as if in appreciation of the sustenance, before being taken into the mouth in bites. Toasts between the various guests, and between the guests and host, marked the eating, which proceeded quickly, as all were aware that there were many mouths to feed and others would take their place once done. These protocols were all outlined in passages within the Book of Origins. ... 
Outside, one of Jjivo's grand-daughters, dressed in a pink party dress, ran to and fro among the guests, followed by several younger children. Jjivo had kept mostly aloof of the proceedings, aside from offering the obligatory toasts. Having disappeared into a low building in the courtyard, his tall, lanky form now reappeared garbed in traditional clothing: a simple, unembroidered black tunic and the bright blue wide-cut pants with unsewn cuffs that were said to be "good for fighting" and marked the former male dress code in the area. These, we were told, were his death clothes, to be worn when he was cremated so that he would be recognized by the ancestors upon entry to the land of the dead.

From a small cloth bag Jjivo removed six red booklets and other papers marked with various seals and signatures representing the various ranks and achievement of his life. He placed

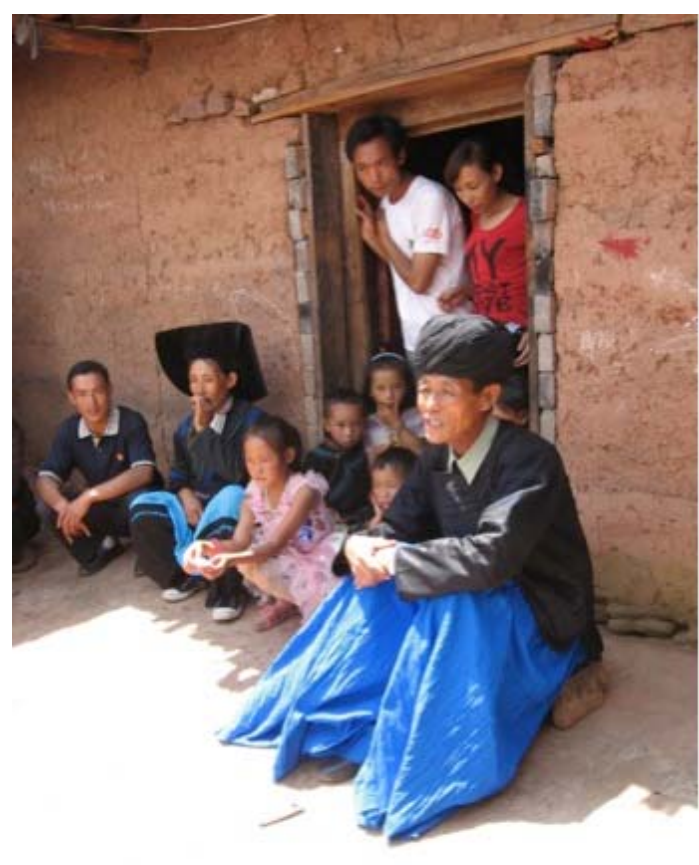

Image 4: Jjivo Zoqu reciting a passage from the Book of Origins. them side by side on the ground for us to examine. Once this official curriculum vita had been perused by all and photographed, Jjivo now took up a seat in the widest area of the courtyard. As our cameras absorbed the scene, one of the more lively men amicably scolded him about his sartorial disarray and helped to arrange his flowing pants, that could easily be mistaken for a dress, properly between his legs. With this, Jjivo took in hand copies of the Book of Origins and the Book of Practices (Hmamo teyy) which he had handcopied and translated from crumbly ancient scrolls into an irregular form of modern Yi script. Moments before, they had been laid carefully by the door of the small building and several of the guests and immediate relatives had respectfully passed them around and examined them. Holding a volume, he looked out at the audience assembled of men, women, and children - both guests and close relatives - and broke into a few lines honoring the event, followed by a recitation of a passage from near the beginning of the Book of Origins concerning the initial creation of the sky and earth:

In the most ancient times,

there was no sky above;

were there a sky, there were no stars.

There was no earth below;

were there an earth, there was no grass.

In between there were no clouds, the clouds had not yet formed;

thus there was no light within the clouds. 
Crisply enunciating each word, his low, raspy voice murmured in the epic recital cadence for several minutes before abruptly stopping. The audience was still attentive, though during the recitation of passages from the Book of Practices, the traditional advice on Nuosu living, the attention of some members began to stray. Yet there was still a general air of deference to the social constraints involving the act of performance. His final recitation was a passage of proverbs. This sampling of texts and performance styles presented before a local audience was a highlight of the trip up the mountain. Although epic performances are usually associated with ritual events conducted by the bimo priests, or sung antiphonally by folksingers at funerals or weddings, this occasion was enough of an event in itself to warrant a special performance by Jjivo, though maybe not of the most typical sort. In his role as a ndeggu, a wise man and dispute arbitrator among the local people, Jjivo clearly had status and respect, embodied for a few moments in the act of performance. Group and individual photos followed, in every combination of kinship and guest. His one request of me was a photo of himself and me engaged in a traditional Yi wrestling hold.

At some point someone had lined up the family tools against the wall of the cooking and storage building, inside which were several large cooking woks. The items consisted of two small sickles for cutting grain, a large, long-handled wooden scoop for ladling animal feed, a sharp pointed butcher knife, a long-handled axe with a square poll. . . . Like other aspects of Nuosu material culture, the tools were bare bones. There were also several styles of baskets and sieves and on top of the stock pens, which contained pigs, goats, and a horse-well-concealed behind small wooden doors. ...

Many of the tools, dwellings, clothing, and customs I observed appear in the Book of Origins - and as part of our practice Aku and I have made every effort to see, handle, and experience all such manifestations of allusions in the epics.

\section{Conclusion}

A great deal more could be said about the many local efforts to process and sustain traditions of oral epic in the southwest and other parts of China today. For instance, Yang Zhengjiang of Guizhou province was part of a local team that documented and published a version of a lengthy funeral chant with epic properties called King of Yalu (Yalu Wang) from the Miao (Hmong) ethnic group (Zhongguo minjian wenyijia xiehui 2011). A few more examples from the Yi areas of the southwest include the work of local researchers such as Shi Youfu of Honghe County in Yunnan province, who has actually studied and become a bimo priest in order to enhance his projects, including the translation of folk narratives of his Yi subgroup, the Azhe. Huang Jianming, a researcher from the Sani sub-group of Yi in Shilin county, Yunnan, has cooperated with local officials to collect and publish oral and written versions (in Yi and Chinese translation) of a narrative poem about the local heroine Ashima and a version of a funeral chant for guiding the souls of the dead to the land of the ancestors (Huang 2012). He has also established a museum devoted to scripts of the ethnic minority groups on the campus of the Central Nationalities University in Beijing. Many of the sample texts are oral-connected epics and other verbal art. At the most local of local levels, in 2007 I documented a husband and wife 
team from Yuxi county, Yunnan, who help to call in the spirits of dragons at a county temple complex called Nine Dragons Park during an annual festival sponsored by the local government. The couple leads a dance troupe of women in their thirties and forties who participate in the dragon calling rituals that contain material found in Yi creation epics from Yunnan. The wife, though illiterate, is still considered a bimo and knows all her husband's chants - as well as her own - by heart. When interviewing them, I wondered about their hopes for the future of the dragon-calling tradition once she and her husband are too old to carry on. She answered that some years before she had been ill for seven years, and that at the time three song "books" had come to her in her dreams. She paused for a moment and explained that when she and her husband become too old, "The gods will find people to do it."

A host of tradition-bearers, government researchers, scholars, poets, officials, and interested others - as individuals and in groups - work at local levels today to help promote, preserve, and process local oral traditions. These efforts are key to sustaining local culture and formally or informally contribute to present government goals for the documentation and preservation of "intangible culture." I hope this brief introduction to the activities of Jin Dan and his children, and of Aku Wuwu and Jjivo Zoqu, will help us to better appreciate the efforts of those involved in projects to document and sustain epic traditions in China and increase our understanding of what it means to "process epics" at this transitional moment in Chinese history today.

The Ohio State University

\section{References}

Aku 2005

Aku and Bender 2006

Bender 2006

Feng 1999

Foley 1995
Aku Wuwu. "Four Poems." Trans. by Mark Bender and Jjiepa Ayi. In Blood Ties: Writing Across Chinese Borders. Ed. by Frank Stewart. Manoa, 17. Honolulu: University of Hawai'i Press. pp. 119-21.

Aku Wuwu and Mark Bender. Tiger Traces: Selected Nuosu and Chinese Poetry by Aku Wuwu. Columbus, OH: Foreign Language Publications.

Mark Bender, trans. Butterfly Mother: Miao (Hmong) Creation Epics from Guizhou, China. Based on a version compiled by Jin Dan and Mu Xueliang. Indianapolis, IN: Hackett.

Feng Guangyu. "Shouji zhengli zhongguo minzu yinyue yichan 50 nianchulun jicheng bianjixue" ("50 Years of Collecting and Collating Chinese Traditional Music Heritage: A Tentative Discussion on the Anthologies"). Yinyue yanjiu, 3:17-26.

John Miles Foley. The Singer of Tales in Performance. Bloomington: Indiana University Press. 
Foley 1999

Harrell 2002

Harrell et al. 2000

Harrell et al. 2007

Heberer 2007

Honko 2010

Huang 2012

Jin et al. 2012

Kvideland 2000

Lord 2000

Schipper et al. 2011

WIPO 2002

Yang et al. 2005
John Miles Foley. Homer's Traditional Art. Philadelphia: Pennsylvania State University Press.

Stevan Harrell. Ways of Being Ethnic in Southwest China. Seattle: University of Washington Press.

Stevan Harrell, Bamo Qubumo, Ma Erzi. Mountain Patterns: The Survival of Nuosu Culture in China. Seattle: University of Washington Press.

Stevan Harrell, Ma Lunyz, Bamo Ayi. Fieldwork Connections: The Fabric of Ethnographic Collaboration in China and America. Seattle: University of Washington Press.

Thomas Heberer. Doing Business in Rural China: Liangshan's New Ethnic Entrepreneurs. Seattle: University of Washington Press.

Lauri Honko, ed. Textualization of Oral Epics. Berlin: de Gruyter Mouton.

Huang Jianming. Yiwen jingji "Zhi lu jing” yanjiu ("A Study of the Yi Classic Scripture 'Guiding the Way Scripture,"). Beijing: Minzu chubanshe.

Jin Dan, Wu Yiwen, Wu Yifang, Mark Bender, and Levi Gibbs, eds. and trans. Miaozu shishi: Miao Han Ying duizhao ("Hxak hlieb/Hmong Oral Epics: Miao/ Han/English Multi-linear Edition”). Guiyang: Guizhou minzu chubanshe.

Raymond Kvideland, ed. Folklore Processed: In Honour of Lauri Honko on His 60th Birthday 6th March 1992. Helsinki: Suomalaisen Kirjallisuuden Scura.

Albert B. Lord. The Singer of Tales. 2nd ed. Ed. by Stephen Mitchell and Gregory Nagy. Cambridge: Harvard University Press.

Mineke Schipper, Ye Shuxian, and Yin Hubin, eds. China's Creation and Origin Myths: Cross-cultural Explorations in Oral and Written Traditions. Leiden: Brill.

World Intellectual Property Organization. "Current Status on the Protection and Legislation of National Folklore in China." Paper presented by the Delegation of China. June 14. Geneva.

Lihua Yang, Deming An, and Jessica Turner. Handbook of Chinese Mythology. Oxford: Oxford University Press. 
Yu 2005

Zhongguo minjian wenyijia xiehui 2011
Yu Xiaofei. Kiki-ni hinsita chugoku syosuu minzoku-no gengo to bunka ("Crisis and Extinction of a Chinese Ethnic Minority Language and Culture"). Tokyo: Akashi shoten.

Zhongguo minjian wenyijia xiehui (Chinese Folk Art Artists Association). Yalu Wang: Han Miao duizhao ("King of Yalu: Bilingual Han and Miao Text"). Beijing: Zhonghua shuju. 
This page is intentionally left blank. 
Oral Tradition, 27/1 (2012): 247-266

\section{"With This Issue ... .": A Record of Oral Tradition}

\section{Compiled and edited by the current editorial staff}

During Oral Tradition's 26 years under John Miles Foley's leadership, "with this issue" became a formula of sorts, a phrase employed in his editorial columns with predictable regularity to signal new opportunities, exciting developments, and future plans in store for the journal. "With this issue," a phrase that appears in some form or another in almost every volume of Oral Tradition, is thus freighted with both celebration and promise, reminding the reader that it is best to look forward while still investing the time to take stock of present events. While each editorial column in its original context elegantly introduced the contents of a given issue, as a synthesized document these columns can now serve both to chronicle the many exciting changes that advanced Oral Tradition into the successful global and open-access journal that it is today and to highlight the steadfast philosophies and goals that John Foley himself used to steer the journal's direction over the many years.

What follows are abridged versions of selected columns written by Professor Foley between 1986 and 2011, collected with the aim of demonstrating the patterns of scholarship within Oral Tradition as well as milestones in the journal's development. ${ }^{1}$ Within these columns we find both a dedication toward the journal's original mission and also the necessary flexibility that allowed the journal to take advantage of (and overcome the obstacles associated with) developments in technology and increasing globalization among Oral Tradition's contributors and readership. Thus, alongside his commitment to the democratization of knowledge and his insistence on broadening conversations to include a wide range of disciplines and traditions, John also maintained an openness toward discovery that has worked over the years to bridge generations of scholars, performers, and readers alike.

With this issue, we mourn the passing of John Miles Foley, dear teacher, scholar, colleague, and friend. Yet we also celebrate his life and his legacy, and we invite you to join us as we continue his unwavering commitment to inclusivity, plurality, and forward thinking that has guided this journal so productively from its inception and now enables further progress into a largely uncharted and unwritten future.

University of Missouri

Rhodes College

1 With this goal in mind, the more detailed description of individual issues' contents have been omitted; however, all of these columns (as well as those written by the guest editors of the journal's numerous special issues) can be consulted in their entirety at http://journal.oraltradition.org. 


\section{Vol. 1.1 (January 1986)}

Tradition demands that an editor of a new scholarly journal perform the ritual gesture of justifying the birth of the new academic child, and certainly any periodical named Oral Tradition cannot afford to ignore either the demands of tradition in general or ritual gestures in particular. Nonetheless, those of us assisting at the delivery feel strongly that in this case the proverbial claim that the new medium "fills a gap" really does contain a modicum of truth. For nowhere in the hallowed halls of academia have we found a journal devoted exclusively to the study of oral tradition in its many forms, nowhere a single, central periodical through which scholars in this wide variety of specialties might communicate. And in recent years this simple "gap" has grown into a chasm: there are now more than one hundred separate language areas affected by studies in oral tradition, among them ancient Greek, Anglo-Saxon, Chinese, Japanese, Russian, SerboCroatian, Old French, medieval Spanish, and dozens more; and the disciplines summoned to this collaborative undertaking include, at a minimum, literary history and criticism, folklore, anthropology, linguistics, and history. Thus it is that Oral Tradition is being inaugurated to inform specialists of parallel developments in their own and different areas, to build and maintain bridges among disciplines in order to promote the healthy growth of the field as a whole.

Our publishing program has been tailored to correspond to the various aspects of research and scholarship on oral tradition and on "literary" forms with roots in oral tradition. In addition to individual scholarly essays, Oral Tradition is committed to other kinds of forums for dissemination of the best and latest thinking in this multidisciplinary consortium. We shall be publishing a number of special issues on particular areas or genres, each of them edited by a scholar of eminence. This inaugural issue presents a sample of the mix of survey and analytical essays that we hope will be typical of Oral Tradition. We invite all members of the community interested in studies in oral tradition to join this enterprise, and not only by entering personal and institutional subscriptions to Oral Tradition (always a high priority) but also by contributing manuscripts, responses for the Symposium section, copies of books and offprints of articles for review and report in the bibliography, ideas for special issues, and suggestions about any aspect of the journal's operation or contents. We who work in this rapidly evolving field have long needed a place to communicate about moving the field forward by sharing our ideas and by responding to the ideas of others. It is our hope that Oral Tradition will serve these purposes.

\section{Vol. 1.2 (May 1986)}

In this second issue of Oral Tradition we have some happy news to convey. As of July 1 of the present year, the University of Missouri at Columbia will be the home of a Center for Studies in Oral Tradition, a place and a modest facility which we hope will serve as a focus for studies in this emerging field.

The Center will, of course, assume responsibility for the editing of Oral Tradition, and in addition will serve as the editorial base for two other publishing ventures. One of these will be a monograph series on oral traditions; the series will include between one and four volumes each year and has been named in honor of Albert Bates Lord. In addition, the Center for Studies in 
Oral Tradition is in the process of creating an archive of primary and secondary materials, with special emphasis on fieldwork collections. We shall be pleased to serve as a deposit facility, so that scholars with taped and manuscript records can store a safety copy in our library.

The first annual bibliography will appear in the next issue of $O T$, along with a wide selection of survey and analytical essays. Fittingly, Albert Lord has provided the lead article, a sequel to his "Comparative Perspectives" essay of 1974 that comments on recent work on oral traditions, for the very issue that houses the first annual Milman Parry Lectures on Oral Tradition, delivered in April 1985 by Joseph J. Duggan. Once more, we invite submissions for Oral Tradition, as well as for the new monograph series (the Albert Bates Lord Studies in Oral Tradition) and for Southeastern Europe. We also look forward to detailed and cogent responses to articles as they appear, to be published in the Symposium section of $O T$ as soon as possible after they are received. In addition, notices of pertinent upcoming events and reports on conferences and symposia are always welcome.

\section{3 (December 1986)}

With this issue Oral Tradition comes to the end of its first year of existence, and it thus seems an appropriate time to thank all those concerned with producing the first volume: the authors, reviewers, editorial board, editorial assistants, and not least the readership. The staff at Slavica Publishers deserve special gratitude for their heroic efforts.

The May issue, under the editorship of Ruth H. Webber, will be devoted to Hispanic balladry. In connection with the recently established Center for Studies in Oral Tradition at Missouri, we are happy to announce an upcoming international symposium commemorating the two-hundredth anniversary of the birth of Vuk Stefanović Karadžić, the great Serbian ethnographer, linguist, and collector of oral traditional narrative. To celebrate this occasion, six Yugoslav colleagues will be coming to Columbia to join six Americans for a five-day symposium on the topic "Vuk Karadzić: Oral and Literary Art." Let me close this brief column with an invitation for all readers to take an active part in formulating the early history of $O T$. We welcome your comments and suggestions for the journal, as well as your bibliographical assistance and responses to previously published articles for the "Symposium" section. Notes of conferences or other events of interest to the readership will also be a regular feature. In short, we welcome whatever contribution you wish to make to the shaping of our collective enterprise.

\section{1-2 (January 1988)}

With the present double issue (volume 3, numbers i-ii), Oral Tradition returns to the format of a miscellany, that is, of a collection of essays on a wide selection of traditions intended to familiarize specialists with parallel or analogous developments outside of their home areas. The annotated bibliography of research and scholarship, which follows six essays, now extends through 1985. It has profited from the readership's suggestions and contributions, but we continue to ask for your assistance in making this research tool as useful as possible. 


\section{3 (October 1988)}

With the present issue we are pleased to observe that the typographical format of Oral Tradition has changed. Typesetting will from this point on be done at the Center for Studies in Oral Tradition at the University of Missouri-Columbia. Advances in technology and lowering of equipment costs have combined to make it feasible to assemble text in the various alphabets used by the journal without leaving the editorial offices, and without making concessions in the form of either deleting original-language quotation or depending solely on transliteration.

\section{3 (October 1989)}

With this issue of Oral Tradition we reach a benchmark of sorts: the end of the journal's first four years of publication and the end of the sixth year since its inception as a scholarly enterprise. Over those four volumes and twelve issues we have tried to bring before a diverse readership an equally diverse collection of essays on the world's oral traditions and their impact on literary and other written traditions. A significant percentage of OT's pages have thus been devoted to miscellaneous topics, with forays into such areas as Australian, central Asian, ancient, medieval, and modern Greek, Biblical, Old and Middle English, Old Irish, Middle High German, Chinese, Arabic, Hispanic, African, Italian, Persian, Old French, Welsh, Asian Indian, SerboCroatian, Rumanian, and modern American traditions. Some of these essays have consisted of surveys of research and scholarship; others have been analytical articles that concentrated on a single work or subject within the broader framework. Oral Tradition has also mounted several special issues - a tribute to Walter J. Ong in 1987, a collection on Hispanic balladry in 1988, and, most recently, the double issue on Arabic in 1989 - and annotated bibliographies of recent research and scholarship in the field.

As we look ahead to the next decade, OT will endeavor to maintain a similar array of contents, making every effort to act as a forum for interdisciplinary work on oral tradition. The present issue represents the kind of heterogeneity we hope to continue to encourage: two of the articles concern living traditions (Hungarian folk dance and central Asian epic) on which their authors have done extensive fieldwork, while the others treat oral-derived texts best understood, it is argued, from the double perspective of orality and textuality. Finally, William Scott, Milman Parry lecturer for 1989, gives us a perceptive and extremely readable discussion of the dynamics of oral composition in the Odyssey, with special attention to the portrait of the singer.

We continue to seek the aid of our readership in proposing books for review and relevant research for annotation in $O T$ 's bibliographical supplements. We would also be grateful to hear from individuals who would like to undertake the kind of review-article exemplified in this and other issues. 


\section{1 (January 1990)}

... In future issues of the journal we plan a variety of contents, with approximately every third number devoted to a special area or topic. Upcoming special issues include Ruth Finnegan's and Margaret Orbell's collection on the oral traditions of Oceania (5, ii-iii); a group of essays on Yugoslavia, edited by John Miletich; and a third number on Native American traditions, under the joint supervision of Barre Toelken and Larry Evers. For every such highly focused collection we plan two miscellanies or "potpourri" issues, with emphasis on the variety of oral traditions - modern, medieval, and ancient. We see the documentation (if this is not too "un-oral" a term) of that heterogeneity as our primary mission; indeed it is our hope that an increased awareness of the richness and complexity of oral traditions worldwide will help all specialists to a greater understanding of their own particular corners of that world.

Toward such an end this issue presents a wide variety of scholarship on oral traditions from various places and eras. As we hope has become our own modest "tradition" over these five years, we welcome submissions to the journal in any and all areas; in short, we look forward to learning more about oral tradition.

\section{2-3 (May 1991)}

With the present double issue on Serbo-Croatian traditions, Oral Tradition comes to the end of its sixth year of publication. Devoting a special issue to this part of the world at this particular time is of significance in at least two ways. First, as these essays go to press, the postwar creation called Yugoslavia is in the throes of disunification, with Croatia and Slovenia having declared independence and Serbia attempting to maintain the nation-state. Warfare has broken out; lives are being lost and cities destroyed. We can only hope that some solution to the long-standing ethnic hatred can be found, for the sake of all concerned.

In the midst of this hostility, it may be difficult to remember that Yugoslavia was, with ancient Greece, the birthplace of what is historically one of the most important approaches to studies in oral tradition. In 1933-35 Milman Parry and Albert Lord undertook the field expeditions throughout Yugoslavia that would lead to an unparalleled acoustic and dictated archive of traditional oral narrative, primarily epic. This region served in effect as the "living laboratory" in which, they theorized, Parry's hypotheses about the dead-language tradition of Homeric epic could be tested. That beginning has led to investigations by hundreds of scholars in scores of different language areas, and we have the guslari of the South Slavic lands to thank for helping to make possible this way of understanding oral tradition.

Thus it is especially poignant to report the recent death of Albert Lord, the co-founder of what has become known as the Oral Theory (but which by its demonstration in dozens of traditions has moved well beyond the status of a hypothesis). With his classic The Singer of Tales, the editions of Serbo-Croatian Heroic Songs, numerous articles, and the 1991 Epic Singers and Oral Tradition, Lord transformed the original juxtaposition of Homer and the SerboCroatian bards into a genuinely comparative field of investigation, wherein today we can learn about similarities and differences among traditions from all over the world. Because it was 
Albert's work that, more than that of any of his contemporaries, created a need for this journal, Oral Tradition will dedicate its next issue $(7, \mathrm{i})$ to his memory.

Before closing let me note that $O T$ will be moving to a slightly different schedule and format starting with the 1992 volume. Instead of a triquarterly, which has proven unwieldy and expensive in the present economy, we plan to issue the journal as a biannual. But, although each volume will have two rather than three parts, the same total number of pages per year will be maintained. The greater single-issue length will also allow the introduction of a new feature: "clusters" of essays on particular topics or areas, amid the customary mix of articles on a variety of fields. We hope the new format will allow even greater representation of the heterogeneity of the vast collection of oral traditions around the world.

\section{1 (March 1992)}

With the present issue Oral Tradition embarks upon its new editorial program of two per volume and year, each to be approximately fifty percent larger than the standard triquarterly number. This format is intended to make possible certain changes in the journal: in addition to bringing costs more under control and providing the same annual page allotment, it is designed to make for greater heterogeneity in each issue. The increased space will of course mean that more different traditions can be examined in a given number, and it will also make room for "clusters" of essays on a particular subject or in a particular field, groups of articles that will constitute a focus amid the natural diversity of OT's responsibilities. We will also maintain the possibility of devoting an entire number to a single area, so special issues such as those that have appeared in the past will remain part of the editorial program. Since the journal was established in order to facilitate communication among scholars sharing an interest in oral tradition but segregated by the disciplinary structure of modern academia, this enhancement of diversity in OT's contents seems appropriate.

\section{1 (March 1993)}

This first issue of 1993 marks the beginning of the eighth year of publication for Oral Tradition, and with the new year comes a resolution and a change in policy. Readers will notice that this issue contains an extensive Books Received listing in its final pages. This digest, and those to follow at regular intervals, will constitute an invitation for specialists in various fields to contribute a brief review of approximately 500-1000 words on any of the volumes listed. We look forward to working with you on this new project.

With this issue we also present another cluster of essays, this one on ancient Greek poetry. It was of course this area in which Milman Parry began his epoch-making research. This cluster illustrates some of the major directions that scholarship on Homer and his colleagues have taken since Parry's original work. Ursula Schaefer's 1991-92 Lord and Parry Lecture closes the volume by urging a reassessment of medieval texts with roots in oral tradition, specifically from the vantage point of reception theory. 
Upcoming issues will feature articles on rap music, Hispanic ballads, the Finnish Kalevala, Arabic bridal songs, Tibetan oral traditions, the performance of Old English poetry, and many other topics. On the horizon are special collections on Native American and African traditions.

\section{2 (October 1993)}

What we might call the "bookends" to this second and final issue of Oral Tradition for 1993 represent a new direction for the journal. One of them consists of an interview with George Sutherlin, aka DJ Romeo, a traditional oral artist whose specialty is rap music. At the other extremity of the present issue lies a transcribed performance of sorts, in this instance a group discussion of "Orality and Deafness" that was conducted on the electronic network ORTRAD-L sponsored by the Center for Studies in Oral Tradition at Missouri. Within the fascinating and often bewildering mix of media that constitutes contemporary Western expressive and perceptual repertoires, we hope these two examples of (textualized) non-print, performance-based interactions shed some light on the complex processes associated with oral tradition. Within the bookends this issue's potpourri includes contributions on Finnish, Hispanic, Anglo-Saxon, Arabic, Greek, and French traditions. All in all, we trust that this heterogeneous selection fulfills $O T$ 's commitment to maintain a broad comparative view.

In our next issue, that perspective will be focused on the tremendous variety and richness of African oral traditions. Special editor Lee Haring has assembled a valuable collection of nine essays, plus his introduction, on topics as diverse as Chokwe storytelling, Igbo epic, Somali women's poetry, and Hausa rap artists.

\section{2 (October 1994)}

Each number of Oral Tradition attempts to foster understanding of individual traditions through reference to the remarkable variety of forms presented to us both as living phenomena and as works now preserved only as texts. If the conversation is to prove useful and enlightening, it must be as diverse as possible, striving to place verbal arts in their widest and deepest possible context. Because the study of oral traditions - for that matter, even their discovery - is so much in its infancy, we assume and expect that this interpretive context will continue to evolve, as analogues arise, connections are made, and distinctions are drawn.

The present issue of $O T$ has as much potential for further articulation of our joint field as any so far published. Even a mere list of the subjects examined bears this out: Mexican folk drama, Tibetan religious works, African American novels, international ballads, and a focused cluster on "Editing and Oral Traditions" that treats Native American, ancient Greek, AngloSaxon, and Egyptian. Equally as heterogeneous, however, are the perspectives and approaches used by authors, including performance studies, ethnopoetics, textual analysis, oral theory, rhetoric, and religious studies. The result is a group of extremely diverse essays, each of them adopting a distinctive line of inquiry, that collectively illustrates the remarkable variety of paths 
toward understanding that characterizes studies in oral traditions at this point in their development. Another way to put the same matter is to say that this issue provides a representative overview of the composite field in the mid-1990s, and might well serve as a worthy introduction for students, graduate or undergraduate, in a wide range of courses. It will be performing that function this fall in the seminar on oral tradition at the University of Missouri.

With examples of how Proteus modulates, changing form from culture to culture and genre to genre, playing so many diverse roles in the social drama, we hope to continue to provide our readership with an ever-evolving sense of the human complexity of oral traditions.

\section{1 (March 1995)}

With this issue Oral Tradition reaches a milestone: its tenth birthday. A decade ago quite a number of committed parties joined forces to bring the journal into being, at that point never imagining that anyone would be composing such a preface ten years and some 4000-odd pages later. There are so many people and institutions to thank that I despair of remembering even the most important, but on this unique occasion $O T$ should make an effort to acknowledge-if not to catalogue in classic oral epic style - some of the parents, avuncular relations, and dependable friends without whom the inspiration for such a journal would never have jelled into an ongoing reality.

I think first of the University of Missouri-Columbia and of Deans Milton Glick and Theodore Tarkow, as well as Provost Gerald Brouder, who provided initial funding that partially subsidized $O T$ over its first two years. With the creation of the Center for Studies in Oral Tradition, the university's commitment became a permanent one, with graduate student and faculty staff, part of whose responsibility it became to edit the journal. Dean Larry Clark deserves our gratitude for his continued and thoughtful support of the Center. The other stalwart in those early times, Slavica Publishers, also remains a full partner still today, and I am particularly grateful to its president, Professor Charles Gribble of Ohio State University, for his understanding, his creativity, and his savvy.

The editorial assistants for the journal have been its heart and soul, and we have recorded their names faithfully in every number of our publication. In addition to these noble colleagues, I want to acknowledge the essential contribution of the editorial board and the scores of other manuscript consultants, who responded to requests for their valuable opinions with, for the most part, alacrity and good will. We all wish that such generous participation could be tangibly rewarded; I hope the existence and function of $O T$ is in some way such a reward.

Creating a forum would have served no purpose if no one had anything to say, but there has never been any danger of even a moment's silence in this venue. We receive many more manuscripts than we can publish, and have had to be highly selective over the years. But I am happy to report that this selectivity has not closed the door to younger scholars: assistant professors as well as eminent authorities are numbered among our authors in every issue, and graduate students have been contributors as well. This seems a healthy arrangement if the conversation is to be as broad-based and lively as possible, and we aim to continue to promote as diverse a symposium as we (all of us) can manage. 
Along with diversity of authorship, we have strived to make the contents of the journal as various and inclusive as the multidisciplinary field it serves. Thus, along with occasional special issues on such topics as Arabic traditions and Hispanic balladry, OT has spent most of its allotment on miscellaneous issues - sometimes with clusters on this or that area-but always with the overall goal of presenting the richness of diversity. Perhaps that commitment goes back to the moment when the journal had to be assigned a title, and I hesitated over Oral Tradition, singular, versus Oral Traditions, plural. While the former seemed a more effective scholarly moniker, it is in the spirit of the latter that we have tried to proceed.

\section{2 (October 1995)}

With this issue of Oral Tradition we offer our readership a salamagundi of essays on an international variety of fields. . . . The next issue of Oral Tradition $(11, \mathrm{i})$ will present a unique glimpse of epics along the famous "Silk Roads," an immense stretch of territories and peoples across northeast Europe and vast parts of central Asia. With this issue readers may expect to hear, perhaps for the first time, of Mongolian, Tibetan, Chinese, Indian, Palawan, Caucasian, and Khalkan epics as well as of the Finnish Kalevala, more familiar to those of us laboring in the Eurocentric vineyard.

\section{2 (October 1996)}

Eleven years ago the journal was founded to provide a forum for comparative exchange, a kind of "pituitary gland" to help organize a cross-disciplinary discourse that often suffered from reinventing the wheel. In these first ten annual volumes of $O T$, an electronic index to which will soon be available at the web site maintained by the Center for Studies in Oral Tradition [now available at http://oraltradition.org] we have tried to bring scholars from disparate areas into an unprecedented, productive dialogue. Issue 11, ii illustrates this editorial policy, treating a rich variety of oral traditions and performances, from ballads to Shakespeare to Japanese storytelling, medieval English poetry, Finnish narrative, and African American rap music. Our editorial premise is clear: the best chance for understanding any single tradition lies in a realistic grasp of the plurality and heterogeneity of oral traditions. $O T$ has been and will remain committed to this premise.

Future issues will address the complexities of oral traditions in various ways. Issue $12, \mathrm{i}$ will focus on South Asian women's traditions, opening up an understudied area to closer inspection. Similarly, number 13, i will feature Native American traditions, concentrating on the challenge of cotranslation by a native speaker and an outside scholar. Let me close by emphasizing our wish to broaden the ongoing discussion by whatever means are available. Thus we actively solicit your manuscripts, in any and all fields. We also plan an enlargement of our web site to include not only the annotated bibliography of oral-formulaic theory (already in place) and the index of volumes 1-10 of $O T$, but also titles and abstracts for future contents. Let us know how we can better serve your academic needs. 


\section{2 (October 1997)}

Let me start this editor's column with an invitation before the menu. As always, we seek to publish the best available scholarship on the world's oral traditions, oral-derived texts, and related forms. Perhaps even more insistently than in prior years, as we near the turning of the millennium, studies in oral tradition need both greater breadth and increased depth. That is, Oral Tradition is eager to print articles treating both living traditions (whether fieldwork- or archiveoriented) and manuscript- or text-based works. We welcome your voice, and look forward to your joining the conversation.

The present number of Oral Tradition reflects the heterogeneity for which we have been striving since the inaugural issue in 1986. Finally, Catherine Quick adds to our annotated bibliographical series with the 1986-1990 installment of books and articles pertaining to oralformulaic theory and related approaches to the study of oral tradition. We plan to bring the series up to 1995 soon. All new installments, as well as the original 1982 bibliography, will be available electronically at the website for the Center for Studies in Oral Tradition: http:// oraltradition.org.

\section{1 (March 1999)}

The first number of volume 14 opens with a new emphasis for Oral Tradition. Devoted entirely to Jewish traditions, it examines the interplay of orality and text across the centuries from the foundation of sacred writings (and sayings) through to the present day.

Let me also take a moment to welcome aboard John Zemke, Associate Professor of Romance Languages, as assistant editor. A specialist in Hispanic and particularly in Sephardic oral traditions, Professor Zemke has been of enormous help in preparing the present issue and will be playing a prominent role in the editing of the journal from this point forward.

As ever, we welcome your submissions and your subscriptions with equal and genuine enthusiasm, and look forward to new and exciting developments within our shared field.

\section{2 (October 1999)}

With the present issue Oral Tradition returns to its more common - and in many ways most fundamental — format: a digest of articles on a wide variety of traditions and expressive forms. The rationale for this diversity stems from our editorial commitment to study oral tradition comparatively, to learn more about our "home fields" by juxtaposing verbal arts from all over the world and throughout history.

Further in our future lies a special issue on the minority oral traditions of China, a project undertaken in partnership with the Chinese Academy of Social Sciences in Beijing.

We continue to welcome your best ideas about our shared field of oral tradition. Whatever your specialty—geographically, ethnically, chronologically, or medially—our journal stands ready to present your perspective to a broad, interested audience. 


\section{1 (March 2001)}

Over this and the next issue Oral Tradition will be following a double path it charted a decade and one-half ago and seeks still to follow. The present number houses a miscellany of articles on Basque, Ndebele, ancient Greek, Native American, Old English, and Old Norse traditions, and their authors employ perspectives as diverse as politics and nationalism, comparative anthropology, myth studies, lexicography and semantics, performance studies, and rhetorical theory. In this way we hope to encourage a "polylogue" that avoids the special pleading of disciplinary focus and welcomes a host of divergent viewpoints on what is after all a remarkably heterogeneous species of verbal art.

We are also very pleased to present the Albert Lord and Milman Parry Lecture for 2001, on "Performance and Norse Poetry," by Stephen Mitchell. Indeed, there is some special justice in Professor Mitchell's having delivered this lecture, since he serves as Curator of the Milman Parry Collection, whose contents Albert Lord initially brought before us, as well as co-editor of the second edition of Lord's The Singer of Tales. In the next issue of Oral Tradition we will honor the other half of our ongoing commitment: to devote an occasional number to a somewhat narrower focus on a single tradition or area. Dr. Chogjin, a Mongolian specialist who spent twelve months at the Center for Studies in Oral Tradition at Missouri, is responsible for recruiting the thirteen authors who have written for this unprecedented collection of essays. Not a few of them are in fact the very first professional scholars their ethnic groups have produced, so the special issue they help to constitute promises to be a landmark publication in many ways.

\section{1 (March 2002)}

With this seventeenth volume Oral Tradition offers what has become its stock-in-trade: a cornucopia of articles on the natural diversity of the world's oral traditions and related forms. Indeed, the miscellaneous character of this issue, and of many of our collections over the past decade and one-half, is straightforwardly mimetic of the field itself. Almost weekly one hears of a recently discovered tradition, or a new genre within a well-known oral poetry, or a freshly encountered interface between orality and literacy. If the study of oral traditions initially made its way by attempting to distinguish itself from "literature" and to define itself quite separately as an implicitly homogeneous type of verbal art, so now all indicators seem to be pointing in the other direction. Oral traditions dwarf their textual counterparts in size and variety, and many of the most intriguing challenges arise from the intersection of orality (in all its guises), literacy (in its own many-sidedness), and even the ever more important electronic media. To put it simply, such miscellanies only become more appropriate vehicles for the presentation of research and scholarship as time goes on and our perspectives deepen.

Here the reader will find essays on Native American, modern Italian, Irish, and Indian verbal arts, as well as the New Testament and uses of orality in the Romantic period and the late twentieth century. Finally, we urge our readers to visit our new web site at www.oraltradition.org, where we are beginning the construction of an e-archive for oral tradition. At present, visitors can listen to South Slavic epic and charms, as well as watch a videotaped performance of slam 
poetry; searchable bibliographies are also available there, and much more will be mounted in the months to come. We welcome your suggestions and contributions to this facility, which is intended, like the journal Oral Tradition, as a resource that fosters cross-disciplinary exchange.

\section{1 (March 2003)}

Oral Tradition for 2003 presents something quite different from its usual contents. Over this and the next issue we will explore the "state of our art" across the multiple academic disciplines and hundreds of individual traditions, ancient through contemporary, that collectively constitute our field. That is, this and the next issue of $O T$ will be devoted exclusively to sampling the heterogeneity of studies in oral tradition, to gaining some insight on the variety and limits of investigation and understanding as of the year 2003.

We start not just by admitting but by stipulating that "oral tradition" is in numerous practical ways anything but a unified field. Most obviously, it refers to all verbal art that comes into being and is transmitted without texts, and recent years have shown that it must also encompass myriad forms and genres that interact in many fascinating ways with texts, and now with electronic media. Hopefully, over the past seventeen years the pages of Oral Tradition have contributed to this ongoing reassessment and rebalancing, participating in helping to make us aware of some of the wonderful richness and complexity of "oral tradition" while offering both tradition-specific insights and comparative analogies that can be useful to a responsible citizen of the twenty-first century. That at least has been our goal.

Amid the hurly-burly of these nearly two decades' worth of exchange, $O T$ now seeks to "take the pulse" of the field, a composite field construed as broadly as possible. We do this without in any way suggesting that the measurement is or can be precise or exhaustive; indeed, such is the heterogeneity of our subject that any claim of this sort would be illusory at best. Instead, we aim at a random sampling of what the concept of "oral tradition" means to individual scholars and practitioners, and at what they see as the next challenge(s) in their particular corner of an ever-expanding world of investigation. Among our emphases in the present issue are performance, the Bible, African, Tibetan and Chinese, ancient Greek, Japanese, and Lithuanian, along with entries on Arabic, Basque, South Slavic, and Madagascar. The next issue will feature sections on the medieval world, the ballad, and Hispanic, along with responses on Finnish, the Philippines, and Celtic. The more than eighty contributions over the two halves of the 2003 volume touch on many other fields as well.

We hope that the result is thought-provoking for our readership. The very nature of the exercise precludes expounding anything at length or saying anything "final," of course, but that isn't the point. This collection of perspectives draws whatever strength it may have from its diversity and suggestiveness, that is, from the extent to which its contents awaken ideas within readers' own disciplines and conceptualizations of "oral tradition." Think of these often telegraphic responses as an invitation to dialogue, comparison and contrast, and new directions that might translate fluently to your own field.

Finally, as the dedication page at the beginning of this issue indicates, the collection as a whole is offered as a Festschrift for Robert Payson Creed, who introduced me to Old English 
poetry and oral tradition. I remember vividly how he made both subjects vital and very much alive via his daily seminar performances of scenes from Beowulf in the original Anglo-Saxon. As one of Albert Lord's early students, and as an accomplished scholar and thinker who has contributed essentially to our grasp of (as he himself put it) the "making of an Anglo-Saxon poem," Bob has made a singular difference in many of his students' lives. I present him this tribute on behalf of all of us. Wes pu, Robert, hal!

\section{1 (March 2004)}

With the first issue of volume 19 we return to Oral Tradition's most customary (even archetypal) format: a collection of six medium-sized essays on a variety of areas spanning both geographical and historical space. Volume 18, which comprised two anthologies of brief reports on the world's oral traditions and related phenomena, aspired to bring before our readership some reflection of the enormous diversity of the subject to which this journal has attended for nearly twenty years. Now we resume what has become our conventional style, but perhaps with an increased awareness of the remarkably diverse background against which studies in oral tradition must be understood.

Prior contents are now listed in a searchable database [now available at http:// journal.oraltradition.org/articles/advancedsearch]. As always, we welcome your reactions, your advice, and especially your manuscripts.

\section{2 (October 2004)}

With this issue of Oral Tradition we offer our readership perspectives on a cornucopia of traditions from around the world and from ancient times to the present day, and at the same time we inaugurate the new feature of E-Companions that will become a staple of our publication program.

From this issue onward, Oral Tradition will, whenever feasible and helpful, enlist the opportunities afforded by the internet to flesh out its contents in as realistic and genuine a way as possible. Specifically, we plan to supplement the articles that appear in the physical and virtual pages of the journal itself (as published in paper format by Slavica Publishers and in virtual format as part of Project Muse) with a facility we call the E-Companion. Consisting of such supplementary aids as streaming audio and video, photographs, and ancillary text-based items such as bibliographies and appendices, these E-Companions are meant to accomplish what the published article by its very nature cannot: to fill in some of the background of real-life context and experience that is by convention eliminated from even the most carefully prepared textual document. Hopefully, they will help the reader to become a better, more faithful audience for the oral tradition under consideration. ... .

In closing this column let me share the happy news that the Center for Studies in Oral Tradition, the original and continuing home to the journal Oral Tradition, will next year celebrate its twentieth year of existence. And in that very year the CSOT will be welcoming an 
infant sibling at the University of Missouri: the Center for E-Research. The CER is being established to study and facilitate computer- and internet-based research across the disciplinary spectrum, with a view to helping coordinate communication among different areas. Toward that end it will inaugurate an online journal, E-Research, as well as undertake cooperations with other institutions in this emerging area of inquiry. We welcome proposals and news items from all quarters.

\section{1 (March 2006)}

With the present issue Oral Tradition enters a new era in its history. After twenty years as a bound paper volume, with online availability since 2004 through subscription to Project Muse, $O T$ is presently in the process of migrating to a web-only, gratis publication. In 2006 it will be published in both media, but as of 2007 it will become a freestanding electronic entity posted on the Center for Studies in Oral Tradition website.

Why have we chosen to follow this path? First and foremost, we aim, as always, to foster productive exchange among an interdisciplinary, international constituency, and to make that exchange as smooth and barrier-free as possible. OT was founded in 1986 to facilitate communication across disciplinary boundaries and among colleagues who otherwise would share no common forum. Since the internet has become the communicative instrument par excellence, creating a massive network with immediate and universal access, we feel it's time for scholarly exchange to leverage its enormous potential to the fullest.

Second, we are committed to making $O T$ a free, gratis publication for the greater good of all concerned. Along with correcting problems inherent in distribution networks for paper publications, we intend to remove all financial barriers as well. Prospective readers of the journal will need no more than a web connection and a browser; all of our content from this issue onward will be open and continuously available worldwide without subscription fees of any sort.

Third, although we are beginning our online version of $O T$ with the first issue of volume 21 , we plan to make all back issues of the journal available in the same virtual format over the next few years. We will start with the inaugural volume (1986) and progress through back issues until the entire run of the journal is posted.

Concurrently, and in the context of this fundamental media-shift, much will remain the same. The vetting procedures for manuscripts submitted to OT will not change: our journal will be refereed in precisely the same fashion as during the last two decades, with one specialist and one generalist reviewing every submission before an editorial decision is made. Likewise with our recently introduced feature of eCompanions, the electronic appendages (audio, video, photos, etc.) meant to accompany the text of articles. Only in this case readers will no longer have to manage texts and eCompanions separately; the links to ancillary materials will be embedded in the online text of the articles in question.

We at the Center for Studies in Oral Tradition are extremely excited about the latest chapter in the journal's biography. We believe that this migration will be generally helpful to all readers and contributors, and especially important for scholars and students in those parts of the world that (as letters to the editor testify weekly) have through no fault of their own seldom or 
never had access to our journal. Ironically, these are also some of the areas with the most thriving oral traditions. We very much hope that an online, gratis $O T$ will correct this systemic imbalance and encourage both new readers and new contributors in what is, after all, our joint project.

The current addition to that project consists of what has become OT's stock-in-trade over the past twenty years: a miscellany with articles on a wide variety of oral traditions from various parts of the world and from ancient to modern times. As always, and as a result of our move to the internet more inclusively than ever, we solicit your contributions to what will be modulating into an even more broadly based "eConversation."

\section{2 (October 2006)}

The present issue of Oral Tradition represents the end of one era and the beginning of another. Volume 21, number 2 marks the final appearance of $O T$ in printed format; as of volume 22 , number 1 , the journal will be available only as $e O T$, an online, open-access, and free-ofcharge periodical.

We are excited about the early reaction to migration from paper to electronic formatwithin two weeks of launching in mid-September, 2006, the eOT site http:// journal.oraltradition.org experienced more than 4000 non-identical hits and twice that many page-views. Perhaps more importantly, our tracking software indicates major readerships in Asia, Africa, and South America as well as Europe and North America. Likewise, we have begun to receive submissions from scholars and researchers in heretofore under-represented areas, and we heartily encourage more voices to join the discussion. Enlarging our readership and authorship to areas usually difficult to reach through text-based Western distribution networks was and remains the primary reason for our conversion of $O T$ to an online, open-access, and free-of-charge medium.

The current miscellany follows our customary pattern of offering perspectives from diverse oral traditions, in the hope that comparative observations and examples may prove broadly useful to our (ever more) diverse readership. On the near horizon, OT will devote 2007 to two special issues on strikingly different topics. The first will focus on the American folk singer Bob Dylan and his relationship to oral tradition, deriving from a conference at the Université Caen and guest-edited by Catharine Mason and Richard Thomas. The second issue will present an in-depth view of Basque oral traditions. We are confident that these two collections will prove interesting and valuable across the wide and multidisciplinary field of studies in oral tradition.

As always, but now with a broader purpose, we urge you to send us your work on oral tradition for publication in online OT. Our reviewing policy will remain the same as in the past: one specialist and one generalist will read the submission before an editorial decision is reached. But now we can offer an enormously larger and more diverse audience for your ideas, an audience that paper publication media simply can't reach. We will continue to publish online eCompanions (audio, video, and other support for text) as needed, as embedded links in articles that can be downloaded free of charge by anyone with a web connection and a browser. Please join us as the second generation of Oral Tradition begins in the virtual community. 


\section{1 (March 2008)}

With the present issue, Oral Tradition begins its twenty-third year of publication. We are happy to report that the entire run of the journal, from the inaugural issue in 1986 through the present number, is now available as an open-access, searchable, and free-of-charge online resource. In other words, scholars and students from anywhere in the world can read or download any of approximately 500 articles on the world's oral traditions, amounting to some 10,000 pages - all without subscription fees of any sort. And the tracking software on our server strongly indicates that they have been doing just that: people from 109 different countries, using browsers in nearly 50 languages, have visited the site. Just as importantly, we are now receiving submissions from a much wider range of potential authors, many of them based in areas where they have firsthand experience of thriving oral traditions. We look forward to helping more people join the international conversation that Oral Tradition was long ago established to support.

\section{1 (March 2009)}

With this issue of Oral Tradition we offer our readership a highly diverse group of articles that treat traditions from around the world and from ancient times to the present. Moreover, the contributors take a rich variety of approaches to their subjects, reflecting the mix of disciplines that make up the composite field of studies in oral tradition.

Our first paper, the Albert Lord and Milman Parry Lecture on Oral Tradition for 2009, describes and analyzes the living Sardinian tradition of mutetu longu, a competitive performance-poetry in which three to five contestants vie with one another over a topic they are assigned just before the event begins. On the horizon are two special issues of Oral Tradition, one entitled "Sound Effects" and dedicated to the long oral-aural history of verbal art in English; and the other a collection treating the role and importance of oral traditions for core texts in Judaism, Islam, and Christianity.

As always, we invite all of our readers to become contributors by sending us their best thinking on the world's oral traditions.

\section{2 (October 2010)}

With this issue Oral Tradition, founded in 1986 at the University of Missouri, reaches a milestone: the conclusion of its twenty-fifth year of publication. The raw numbers are significant - more than 500 articles comprising more than 11,000 pages treating close to 100 different oral traditions worldwide from ancient to modern times. But two other measurements are perhaps just as telling. Since 2006, when the journal first became available online, open-access, and free-ofcharge (with all review procedures intact and in force), our constituency has increased from a maximum of 1200 paper subscriptions to an annual readership of over 20,000 from 216 countries and territories internationally. Just as importantly, we now receive submissions for possible 
publication from a much wider range of colleagues studying a much more diverse group of traditions from more markedly varied theoretical perspectives. In addition, many articles now feature audio, video, photographic, and other support in the form of eCompanions, thus providing multimedia experiences of performers, performances, audiences, and the like. In this way the electronic medium has liberated the understanding of oral traditions from what can be contained in a text, just as it has radically democratized access and contribution. In short, by taking advantage of the natural homology between humankind's first and most recent communications technologies, an OT-IT homology explored in the Pathways Project, the journal is well placed to continue its growth as a comparative, interdisciplinary forum for scholars and students around the world.

Earlier this year, on February 10th, the Center for Studies in Oral Tradition celebrated its own quarter-century anniversary with several memorable events. Chief among them was the donation of the personal libraries of Albert Bates Lord and Mary Louise Lord to the CSOT and the University of Missouri. We are enormously grateful to Nathan and Mark Lord and their families for this remarkable act of generosity, and are excited to be able to offer this unique resource to visiting scholars and students as well as our own campus community. To mark the donation of the library, the College of Arts and Science at the university has created the Lord Fellowship, which will provide a stipend for visiting researchers who wish to use the collection and other resources of the CSOT. The inaugural recipient is Agniezska Matkowska of Adam Mickiewicz University in Poznań, Poland. As another aspect of the February commemoration, Mark Bender of Ohio State University delivered the 25th Lord and Parry Lecture, entitled "Butterflies and Dragon-Eagles: Processing Epics from Southwest China," which will be published in Oral Tradition next year.

On the same evening of February 10th we also announced the launch of a new initiative patterned after the online migration of the journal: the International Society for Studies in Oral Tradition. The purpose of this Internet-based association is to further the original and continuing mission of the CSOT as a whole - to facilitate the study of oral traditions by promoting and facilitating exchange among all constituencies. With the electronic platform and a variety of virtual tools in place, we will support such activities as individual, person-to-person contacts; group discussions over topics of mutual interest; eSeminars and eConferences; and an eArchive for the deposit of primary and secondary materials. Membership in the ISSOT is free and open to all, and we have built a system that optimizes access while protecting identity through gatekeeping. We hope that the Society will contribute to enhanced democratization of work in our shared field, a goal that harmonizes with the core nature of our joint inquiry. Fittingly, this twenty-fifth year of Oral Tradition closes with a bibliography of Albert Lord's writings, as compiled by Morgan Grey from an obituary article and Mary Louise Lord's additions. Neither the Center for Studies in Oral Tradition nor this journal would exist without Albert's encouragement and fundamental contributions, and we hope that giving pride of place to his seminal work makes that point. In a real sense, and notwithstanding the explosion of comparative, interdisciplinary research and scholarship on oral tradition that has made this field so rewarding and intriguing for an ever-growing international constituency, the quarter-century comes full circle, ending where it began. 
Let me close with an inadequate word of thanks to all those who have participated in the birth and nurturing of Oral Tradition as it has evolved from a rough-hewn idea through bluepenciled manuscripts to the (then-)miracle of in-house typesetting and now to a digital avatar on the Internet. Charles Gribble was an indispensable member of the midwifery team, with his and George Fowler's sponsorship of the journal's publication by Slavica for almost twenty years. Deans Milton Glick and Ted Tarkow, and now Dean Michael O'Brien, have trusted the CSOT and $O T$ initiatives and have been essential partners in the ongoing project from the start. Generations of graduate editorial assistants, more than two dozen in all as chronicled in the succession of mastheads, have performed faithfully and often brilliantly the tasks of copyediting, proofing, and communication with authors, while the Center's IT managers, Mark Jarvis and Jamie Stephens, have enabled the journal's transition from paper to the web and all that has followed in the wake of that migration. Closer to home, a supremely supportive family has created a context that both supports and places in proper perspective all academic undertakings: in addition to more recent arrivals Joe and Bella, my deepest thanks to (in chronological order) Isaac, Lizzie (about coeval with OT), Joshua, and especially Anne-Marie.

\section{1 (March 2011)}

With issue 26, i, Oral Tradition delves into a wide variety of traditions and media in multiple cultural contexts, seeking as always to chart new territory and to expand the horizons of our joint, interdisciplinary field. We see this emphasis on diversity as perhaps the most important role our journal can serve: to report on the international panoply of both longstanding and emerging forms of traditional verbal art.

As the Center for Studies in Oral Tradition and the journal emerge from their twenty-fifth anniversary year, it seems timely to emphasize the recent launch of the International Society for Studies in Oral Tradition (http://issot.org). The aim of the ISSOT, which provides a sponsored virtual platform for exchange among scholars, performers, and students around the world, is to leverage electronic media in order to promote and facilitate communication that otherwise could not happen. We have identified four ways in which the society can benefit the field.

Member-to-member. In the spirit of person-to-person communication, members of the society, which is open-access and free-of-charge, are able to search our data-base to locate colleagues interested in various areas, traditions, and topics, and to exchange ideas and media as they wish.

Webinars. Second, we plan a series of webinars, or seminars broadcast live on the Internet, which will be captured as videos and posted on the ISSOT site for asynchronous viewing. Our first webinar, "Oral Epics in China" (http://issot.org/events) delivered by Dr. Chao Gejin, Director of the Institute of Ethnic Literature at the Chinese Academy of Social Sciences, was attended live in 13 countries; within a week of its posting as a video, scholars from 39 countries had accessed the presentation.

Interviews. Third, in an effort to familiarize colleagues with research, fieldwork, and performance in various areas within our general field, we plan a series of ISSOT interviews with scholars and performers from different parts of the world. Consisting of brief articles and video 
excerpts, these features will allow members to explain their activities in their own words, as well as to include links to pertinent texts and multimedia illustrations.

eResearch groups. In future months, a fourth ISSOT initiative will bring together members from widely separated locales to collaborate on topics that span multiple oral traditions. These eResearch groups, of perhaps six to ten people, will use the ISSOT facility to share their ideas, proposals, scholarship, and media over a four- to six-month period. When the group feels that its deliberations have reached maturity, it will have the option of creating a jointly authored position paper on their conclusions or opening their eDiscussion to the membership or the Internet community at large.

We are excited about the ISSOT initiatives and their potential for developing our field, and we encourage you to register for the society at (http://issot.org/signup) and to participate in its activities. Communication about these four programs should be addressed to Darcy Holtgrave (info@,issot.org), Associate Editor for the ISSOT at the Center for Studies in Oral Tradition. Meanwhile, we continue to welcome your submissions to Oral Tradition and look forward to learning from your contributions. 
This page is intentionally left blank. 
Oral Tradition Volume 27, Number 1

\section{About the Authors}

\section{Ingrid Åkesson}

Ingrid Åkesson is an ethnomusicologist at The Centre for Swedish Folk Music and Jazz Research in Stockholm and a post-doctoral researcher at the University of Umeå, Sweden. Her primary research interests involve various aspects of vocal traditional music, music-making as activity and process, and oral/aural elements in late modernity. Her publications include Med rösten som instrument (a study of contemporary folk singers' approaches to "tradition," 2007), and Folklig koralsaing (on Swedish traditional hymn-singing, with Margareta Jersild, 2000).

\section{Mark Bender}

Mark Bender is an associate professor of Chinese literature and folklore at The Ohio State University. He has published on Suzhou professional storytelling (Suzhou pingtan) and the oral and written literatures of several Chinese minority cultures, such as the Yi, Miao (Hmong), and Daur. His books include Plum and Bamboo: China's Suzhou Chantefable Tradition (2003), Butterfly Mother: Miao (Hmong) Creation Epics from Guizhou Province, China (2006), and The Columbia Anthology of Chinese Folk and Popular Literature, co-edited with Victor Mair (2011).

\section{Katherine Campbell}

Katherine Campbell is a senior lecturer and ethnomusicologist of Celtic and Scottish Studies at the University of Edinburgh, specializing in fiddle and Scots song. She is general editor of the Scottish Tradition Series of recordings from the School of Scottish Studies Archives. Her publications include The Fiddle in Scottish Culture: Aspects of the Tradition (2007) and Songs from North-East Scotland: A Selection for Performers from "The Greig-Duncan Folk Song Collection" (2009).

\section{Sabine Dedenbach-Salazar Sáenz}

Sabine Dedenbach-Salazar Sáenz is Senior Lecturer in Latin American and Amerindian Studies at the University of Stirling (Great Britain). Her research focuses on the Andes, combining ethnohistory, cultural anthropology, and ethnolinguistics. Recent projects include the direction of the documentation of the endangered Bolivian Chipaya language and the Christianization of the Andean peoples in the colonial Quechua language. Her publications include Die Stimmen von Huarochirí (The Voices of Huarochiri) (2003) and Fuentes etnohistóricas de Latinoamérica entre crítica de fuentes y deconstrucción: Contribuciones metodológicas (editor, 2006).

\section{William Lamb}

William Lamb is a Lecturer in Celtic and Scottish Studies at the University of Edinburgh and Director of the department's taught Masters program. His research interests involve Gaelic linguistics and ethnology, and his recent publications include Scottish Gaelic Speech and Writing: Register Variation in an Endangered Language (2008) and Keith Norman MacDonald's Puirt-à-Beul: The Vocal Dance Music of the Scottish Gaels (2012). 


\section{Emily Lyle}

Emily Lyle is a Senior Research Fellow in the department of Celtic and Scottish Studies at the University of Edinburgh. She is the author of Fairies and Folk: Approaches to the Scottish Ballad Tradition (2007) and has also been actively writing on Indo-European mythology and cosmology, most recently in Ten Gods: A New Approach to Defining the Mythological Structures of the IndoEuropeans, forthcoming from Cambridge Scholars Publishing.

\section{Cathlin Macaulay}

Cathlin Macaulay is Curator of the School of Scottish Studies Archives, a repository of folklore, ethnology, and traditional arts based at the University of Edinburgh. Her interests include transmission of oral tradition, and she is particularly committed to enhancing access to audio resources and developing project partnerships with communities and creative artists. She is editor of Tocher, a journal containing transcriptions (with translations) of songs, tales, and traditions from the sound archive.

\section{Slavica Ranković}

Slavica Ranković is a Researcher at the Centre for Medieval Studies, University of Bergen, Norway. Her work rethinks communal authorship, memory, and creativity in light of network dynamics and evolutionary processes that give rise to traditional narratives such as Old NorseIcelandic sagas and South Slavic epics. Ranković is the principal editor of Along the OralWritten Continuum: Types of Texts, Relations, and their Implications (2010) and Modes of Authorship in the Middle Ages (2012). 